\title{
Monitoring the course of CMV infection by detection of specific viral transcripts
}

Citation for published version (APA):

Blok, M. J. (2001). Monitoring the course of CMV infection by detection of specific viral transcripts.

[Doctoral Thesis, Maastricht University]. Universiteit Maastricht. https://doi.org/10.26481/dis.20011213mb

Document status and date:

Published: 01/01/2001

DOI:

10.26481/dis.20011213mb

Document Version:

Publisher's PDF, also known as Version of record

\section{Please check the document version of this publication:}

- A submitted manuscript is the version of the article upon submission and before peer-review. There can be important differences between the submitted version and the official published version of record.

People interested in the research are advised to contact the author for the final version of the publication, or visit the DOI to the publisher's website.

- The final author version and the galley proof are versions of the publication after peer review.

- The final published version features the final layout of the paper including the volume, issue and page numbers.

Link to publication

\footnotetext{
General rights rights.

- You may freely distribute the URL identifying the publication in the public portal. please follow below link for the End User Agreement:

www.umlib.nl/taverne-license

Take down policy

If you believe that this document breaches copyright please contact us at:

repository@maastrichtuniversity.nl

providing details and we will investigate your claim.
}

Copyright and moral rights for the publications made accessible in the public portal are retained by the authors and/or other copyright owners and it is a condition of accessing publications that users recognise and abide by the legal requirements associated with these

- Users may download and print one copy of any publication from the public portal for the purpose of private study or research.

- You may not further distribute the material or use it for any profit-making activity or commercial gain

If the publication is distributed under the terms of Article $25 \mathrm{fa}$ of the Dutch Copyright Act, indicated by the "Taverne" license above, 


\title{
Monitoring the Course of CMV Infection by Detection of Specific Viral Transcripts
}

\author{
Marinus Jacob Blok
}


(C) Marinus Jacob Blok

ISBN: 90-9015374-8

Production: ANDI Press, Geleen, The Netherlands 


\title{
Monitoring the Course of CMV Infection by Detection of Specific Viral Transcripts
}

\author{
PROEFSCHRIFT
}

ter verkrijging van de graad van doctor

aan de Universiteit Maastricht, op gezag van de Rector Magnificus, Prof. dr. A. C. Nieuwenhuijzen Kruseman, volgens het besluit van het

College van Decanen, in het openbaar te verdedigen op

donderdag 13 december 2001 om 14.00 uur

door

Marinus Jacob Blok 


\section{Promotores}

Prof.dr. C.A. Bruggeman

Prof.dr. J.M. Middeldorp (Vrije Universiteit Amsterdam)

\section{Co-promotor}

Dr. C. Vink

\section{Beoordelingscommissie}

Prof.dr. M.H. Hofker (voorzitter)

Prof.dr. J.W. Cohen Tervaert

Prof.dr. J.P.M. Geraedts

Prof.dr. G. Gerna (IRCCS Policlinico San Matteo, Pavia, Italy)

Dr. H.G.M. Niesters (Erasmus Universiteit Rotterdam)

Prof.dr. W.J.M. Spaan (Universiteit Leiden) 
"Door te twijfelen komen we tot de waarheid" Marcus Tullius Cicero (106-43 B.C.) 



\section{Contents}

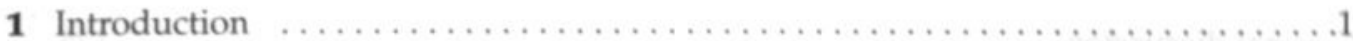

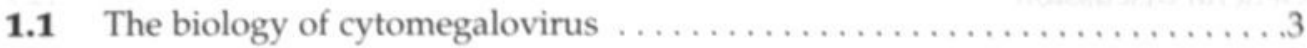

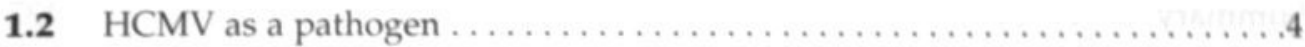

1.3 HCMV disease management in transplant patients ...............6

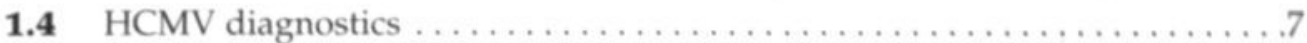

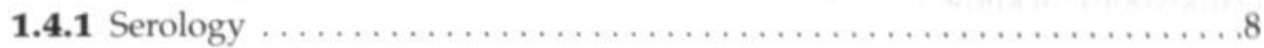

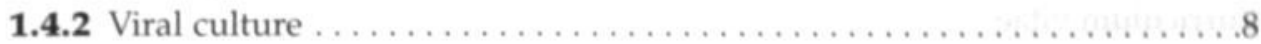

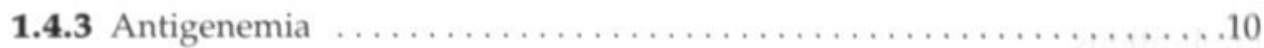

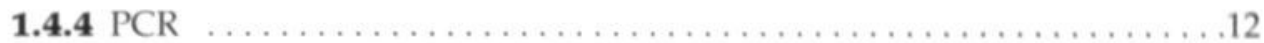

1.4.5 RT-PCR and NASBA ...............................

1.4.5.1 Monitoring of IE mRNA expression $\ldots \ldots \ldots \ldots \ldots \ldots \ldots$

1.4.5.2 Monitoring of early mRNA expression $\ldots \ldots \ldots \ldots \ldots \ldots$

1.4.5.3 Monitoring of late mRNA expression . . . . . . . . . . . . 17

1.4.5.4 Monitoring of antiviral therapy .................. 18

1.5 Localization of $\mathrm{CMV}$ in blood cells during active infection ............18

1.6 Localization of CMV during latent infection ..................... 19

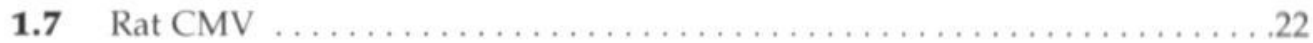

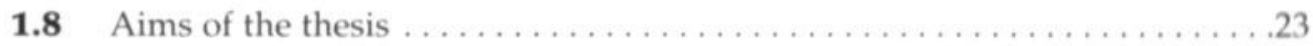

2 Diagnostic value of monitoring human cytomegalovirus late pp67 mRNA expression in renal-allograft recipients by nucleic acid sequence-based amplification

3 Early detection of human cytomegalovirus infection after kidney transplantation by nucleic acid sequence-based amplification

4 Diagnostic implications of human cytomegalovirus immediate early-1 and pp67 mRNA detection in whole-blood samples from liver transplant patients using nucleic acid sequence-based amplification 
5 Immediate early-1 mRNA expression and virus production are restricted during the acute phase of rat cytomegalovirus

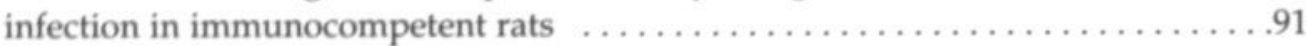

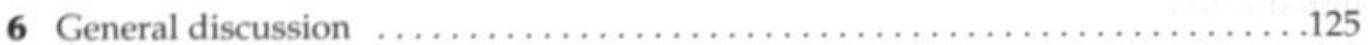

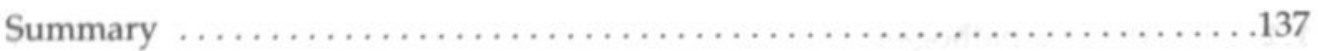

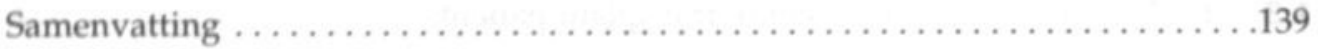

Dankwoord/acknowledgments ..................................

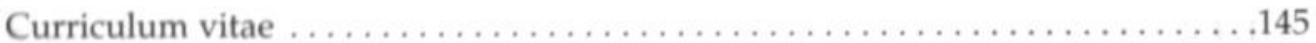

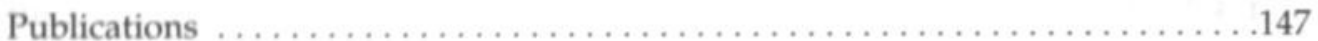


$\sim$ CHAPTER $1 \sim$

Introduction 
CHAPTER 1 


\subsection{The biology of cytomegalovirus}

Cytomegaloviruses (CMVs) are classified as members of the betaherpesvirus subfamily of the Herpesviridae family (183). Infection with CMVs is not restricted to humans but also affects many other animals. The individual CMVs are, however, highly species-specific. The CMV genomes consist of double-stranded, linear DNA and are encapsidated. The size of the genome ranges from 180 kilobase pairs (kbp) for equine CMV to 230 or $240 \mathrm{kbp}$ for human, simian, guinea pig, murine and rat CMV $(183,265)$. The capsid is surrounded by a tegument or matrix. These components are enclosed in a lipid bilayer envelope carrying a number of virally-encoded glycoproteins (Fig. 1).

The replication cycle of CMV is a complex process of regulatory cascades (183). Principally, gene expression during productive replication can be divided into three temporal phases: the immediate early (IE), early and late phase (Fig. 2). IE transcription starts after entrance of the virus into a cell. In contrast to transcription in the early and late phases, the transcription of IE genes does not depend on de novo protein synthesis. The proteins encoded by the IE proteins are important regulators of transcription of viral early genes. The proteins that are synthesized in the early phase of infection are mainly involved in the synthesis of new viral genomic DNA, whereas most late proteins are structural proteins necessary for the assembly of new virus particles, e.g. (glyco)proteins of the capsid, matrix and envelope. The whole replication cycle of human CMV (HCMV) is completed within approximately 48 to 72 hours, whereas murine CMV (MCMV) yields

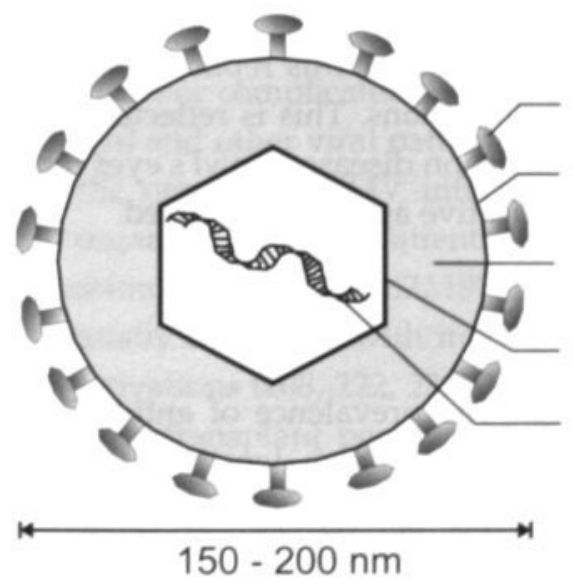

Membrane glycoproteins

Envelope (phospholipid bilayer)

Tegument or matrix

Icosahedral nucleocapsid

Linear double stranded DNA

FIG. 1. Schematic representation of the CMV virion. 


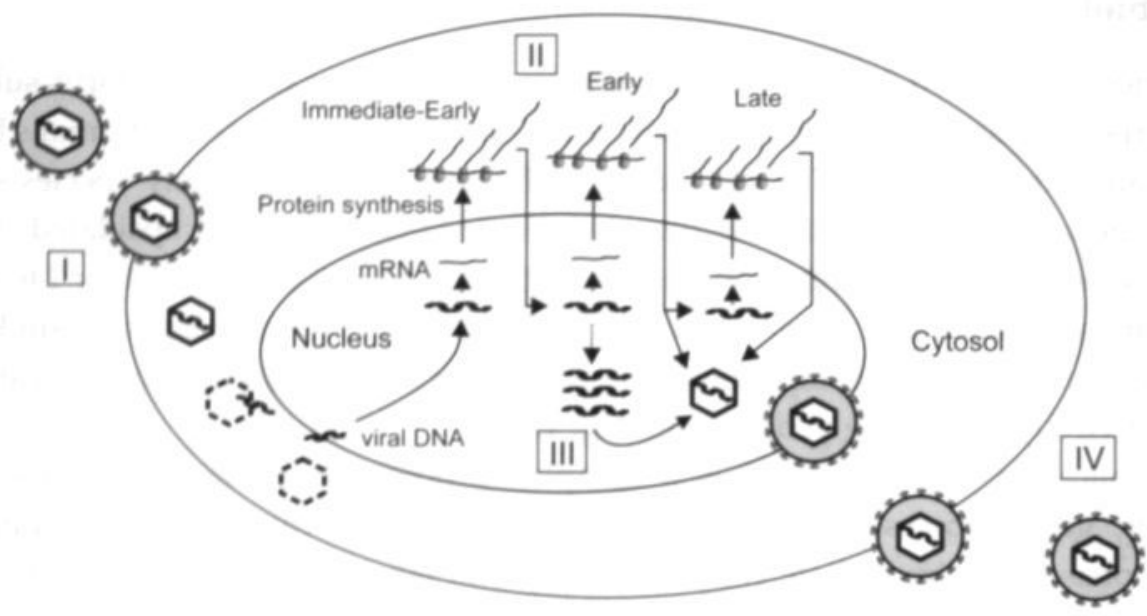

1 Entrance of virus into a cell through fusion of the virus envelope with the cell. The virus capsid is absorbed into the cytoplasm of the cell. After proteolysis of the capsid proteins, the viral DNA is transported into the cell nucleus.

II The viral proteins are synthesized in a temporal sequence.

III Replication of viral DNA and assembly of the virus take place within the nucleus.

IV New virus particles leave the infected cell via the endoplasmic reticulum.

\section{FIG. 2. The replication cycle of $\mathrm{CMV}$.}

infectious progeny in 24 to 36 hours (183). Cytomegalovirus replication characteristically produces cell enlargement with intranuclear inclusions. This is reflected in the name for end-stage in vivo infections as cytomegalic inclusion disease or owl's eyes inclusions (270). These names were defined even before the causative agent was isolated.

\subsection{HCMV as a pathogen}

Infections with HCMV are very common. The prevalence of anti-HCMV antibodies ranges from $40 \%$ to $100 \%$ (136). Socio-economic factors, high density of the population and hygiene seem to correlate with higher infection rates (92). In healthy individuals, infection is limited by the protective response of the immune system. As a consequence, these infections usually remain asymptomatic. Only occasionally, primary infection of immunocompetent individuals results in the onset of clinical symptoms such as a mononucleosis syndrome, persistent fever, hepatitis and pneumonia (121). Although 
infections usually remain asymptomatic, the immune system does not succeed in the complete clearance of the virus from the host and latent virus will remain present lifelong. Intermittent reactivation of HCMV results in shedding of infectious virus in saliva, urine, cervical and vaginal secretions, semen, breast milk, tears, faeces and blood. In this way, the virus can be transmitted by direct or indirect person-to-person contact. The perinatal phase and the phase in which people become sexually active are the two periods in life in which the risk of primary infection with $\mathrm{HCMV}$ is very high $(121,243)$.

Whereas HCMV infection in healthy, immunocompetent individuals usually remains asymptomatic, in immunocompromised patients, such as organ transplant recipients and people with AIDS, active viral replication can result in the onset of severe clinical symptoms $(51,105,199,233)$. These observations point to the important role of cellmediated immune defenses in the lifelong control of HCMV infection. Therefore, bone marrow transplant recipients in whom the complete immune system is replaced are at high risk for symptomatic infection. Symptoms of CMV infection in transplant patients are usually prolonged fever, leukopenia, thrombocytopenia, atypical lymphocytosis, and elevated levels of hepatic transaminases. Life-threatening symptoms include gastrointestinal tract involvement and pneumonia, especially in bone marrow transplant patients $(70,177)$. HCMV also appears to be associated with allograft dysfunction/rejection and decreased graft survival in solid organ transplant recipients, although this association is still controversial $(28,97,109,118,137,193,258)$. The main organs involved in HCMV infections in AIDS patients are the lungs, the central nervous system (CNS) and the gastrointestinal tract (51). Blindness caused by HCMV retinitis is frequently occurring in AIDS patients, but is rarely encountered after organ transplantation. Finally, HCMV infection can be further complicated by the onset of opportunistic infections with fungal, protozoal, bacterial and other viral pathogens $(73,188,203,220,267)$.

In general, the onset of HCMV infection and the possible development of clinical symptoms in organ transplant patients is correlated with the type and degree of immunosuppression $(15,61,153,167,197,209,218,220,228,262)$. Furthermore, primary infections are usually correlated with more severe clinical manifestations than secondary infections or reactivations $(108,222,235,237,239,269)$. Variables which also contribute to infection in the posttransplant period include the source of the allograft (living-related versus cadaveric), HLA matching of donor and recipient, and type and amount of blood products used $(30,74,77,193,196,239,273)$. In general, liver, pancreas, lung, intestinal, and heart transplant recipients have a greater incidence of symptomatic HCMV infection than kidney transplant recipients $(107,120,199)$. Allogeneic bone marrow transplant patients are usually considered as a distinct group of patients, because of the graft versus host disease 
(GVHD), which is only encountered in this group of transplant patients, and their highly immune suppressed state. In addition, mortality rates due to HCMV infections are higher in these patients than in other transplant patients $(156,219,272,274)$. GVHD appears to be an important additional risk factor for development of symptomatic HCMV infection in bone marrow transplant recipients, although its role is still controversial $(29,64,66,122$, $178,186)$. The incidence and severity of symptomatic HCMV infection after autologous bone marrow transplantation is comparable to the situation described for solid organ transplant recipients (213).

\subsection{HCMV disease management in transplant patients}

The onset of HCMV infection in organ transplant recipients occurs primarily in the first three months after transplantation, when immunosuppression is most intense (120). The current strategies for the treatment and prevention of HCMV infection and disease were recently reviewed by Sia and Patel (233).

The first approach in disease management is the determination of the serostatus of the donor and recipient using serological assays (see below), to identify patients with a possible primary or secondary infection. Due to the fact that patients with a primary infection have no existing cellular immunity against HCMV, they are at a higher risk for the onset of symptomatic infection than patients with a secondary infection. Patients with a primary infection should therefore be carefully monitored for the onset of CMV infection.

Reduction of the level of immunosuppression upon detection of CMV infection is considered to be the most simple and effective approach towards inhibition of viral replication, since it allows the natural clearance of HCMV infection by the immune system $(94,187)$. However, this inherently increases the risk of graft rejection and is not an option in patients with severe impairment of the specific antiviral immunity, as is the case for bone marrow transplant recipients.

The current availability of antiviral drugs allows the maintenance of the established level of immunosuppression during antiviral therapy. Ganciclovir is the most commonly used antiviral drug for the prevention and treatment of symptomatic HCMV infection in organ transplant recipients and AIDS patients (48). Two main strategies for the prevention of symptomatic infection can be distinguished, which are different with respect to the time point at which the antiviral drug is administered to the patient.

The prophylactic therapy approach is based on standard administration of ganciclovir to a transplanted patient regardless of the outcome of the laboratory tests for HCMV detection. However, many discrepancies in the reported effectivity of this approach exist $(2,6,8,43,59$, 
$79,149,166,173,189)$. In particular, early inhibition of viral replication will not stimulate the development of cellular immunity against HCMV. This could be a disadvantage for the acute and long-term control of the infection by the patient. Furthermore, the need for intravenous administration of ganciclovir, its adverse effects, e.g. leukopenia, thrombocytopenia, and renal toxicity $(54,75,233)$, as well as the chance of development of drug-resistant virus strains $(3,17,71,138,154,217)$, do not favor prolonged prophylactic use of this drug in every transplant recipient. Thus, unnecessary prophylaxis in patients who are not at risk for symptomatic HCMV infection should be avoided. Instead, initiation of antiviral therapy is preferably based on detection of aberrant HCMV activity by laboratory tests, prior to the onset of symptomatic infection. This would also allow limited viral antigen expression which may trigger immune responses that contribute to improved acute and long-term immunological control of infection. This concept is the rationale of the preemptive therapy approach. However, it strongly depends on the availability of a sensitive and rapid diagnostic assay, with a high positive predictive value (PPV) for the onset of symptomatic infection $(39,62,155,201,221)$. Moreover, besides positive laboratory tests, additional risk factors have to be considered by the clinician to identify possible symptomatic infections. For example, patients with a primary infection or anti-rejection therapy, are at increased risk for the development of symptomatic infection. Thus, a positive laboratory test for HCMV in these patients has additional predictive value and justifies the start of antiviral therapy $(1,2$, $117,126,158,209,256)$. Finally, the ideal diagnostic assay for HCMV disease management should be able to mark the endpoint of HCMV infection which allows discontinuation of antiviral therapy, without relapse of symptomatic infection.

\subsection{HCMV diagnostics}

Currently, many techniques are available for the detection of HCMV in patient specimens. The owl's eyes inclusions, which are characteristic for CMV-infected cells, can be detected in tissue biopsies. Nevertheless, this is not a standard technique that is suitable for early diagnosis of HCMV infection, since it is quite insensitive and inclusions are usually only observed at a late stage of symptomatic infection with organ involvement (11, 44). Preferably, HCMV is detected before the onset of symptoms in samples which can easily be obtained from the patient, such as blood and urine. However, prolonged shedding of HCMV in urine, even after the phase of active HCMV infection, makes detection of $\mathrm{HCMV}$ in urine quite nonspecific for diagnosis of a clinically significant HCMV infection (233). The presence of infectious HCMV in the blood (viremia) is considered as the hallmark of active CMV infection leading to disease. Therefore, preferably blood samples have to be investigated for the presence of HCMV. The clinical use of different diagnostic assays for 
the detection of HCMV was reviewed by Sia and Patel (233) and Boeckh and Boivin (19). The advantages and disadvantages of the most relevant assays are summarized in Table 1. The procedures and diagnostic values of these assays are outlined in more detail below.

\subsubsection{Serology}

Detection of HCMV for diagnostic purposes is usually based on detection of infectious virus or the different viral components, i.e. DNA, mRNA and proteins. Alternatively, the virus can be detected indirectly by demonstration of the presence of anti-HCMV IgG and IgM antibodies. These antibodies were found to be directed mainly against the outer membrane glycoproteins $\mathrm{gB}$ (32) and $\mathrm{gH}$ (234) and the tegument proteins pp28 (UL99), pp65 (UL82) and pp150 (UL32) $(125,144)$ The assays for detection of antibodies include complement fixation tests, enzyme-linked immunosorbent assays (ELISA), enzymatic immuno assays (EIA) and latex agglutination tests. Although these assays can be performed in a relatively short time and allow automation in routine diagnostic laboratories, they appear to be quite insensitive markers for monitoring HCMV infection in immunocompromised hosts, in particular in patients that are already seropositive at the moment of transplantation. Due to the fact that antibodies are formed against antigens that are expressed during infection, the immune response is by definition delayed relative to the onset of infection. Moreover, the immune response is usually further delayed due to the treatment of the patient with immunosuppressive drugs. Furthermore, results of the assay can be blurred by blood transfusions and antibody-based therapy. Serology is therefore of limited diagnostic use in preemptive antiviral strategies and for monitoring the effect of antiviral therapy $(164,195,202,215,238,248)$. However, the serological assays are used to determine a previous infection with HCMV, and thus potential carriership status, in transplant donors and recipients. This is valuable information, since primary infection is considered to be an important risk factor for development of symptomatic infection.

\subsubsection{Viral culture}

Active viral replication results in shedding of the virus into various bodily secretions, as discussed above. The presence of infectious virus in these secretions can be demonstrated by inoculation of samples on cells which are highly permissive for CMV replication, i.e. human fibroblasts. These cultures are screened frequently for the appearance of the typical cytopathogenic effect (CPE) caused by active replication of the virus. However, it can take up to 6 weeks before the CPE is observed. Therefore, this technique is unsuitable for rapid diagnosis of HCMV infection and early start of preemptive antiviral therapy. Results can be obtained much faster by an immunohistochemical staining procedure which is performed 


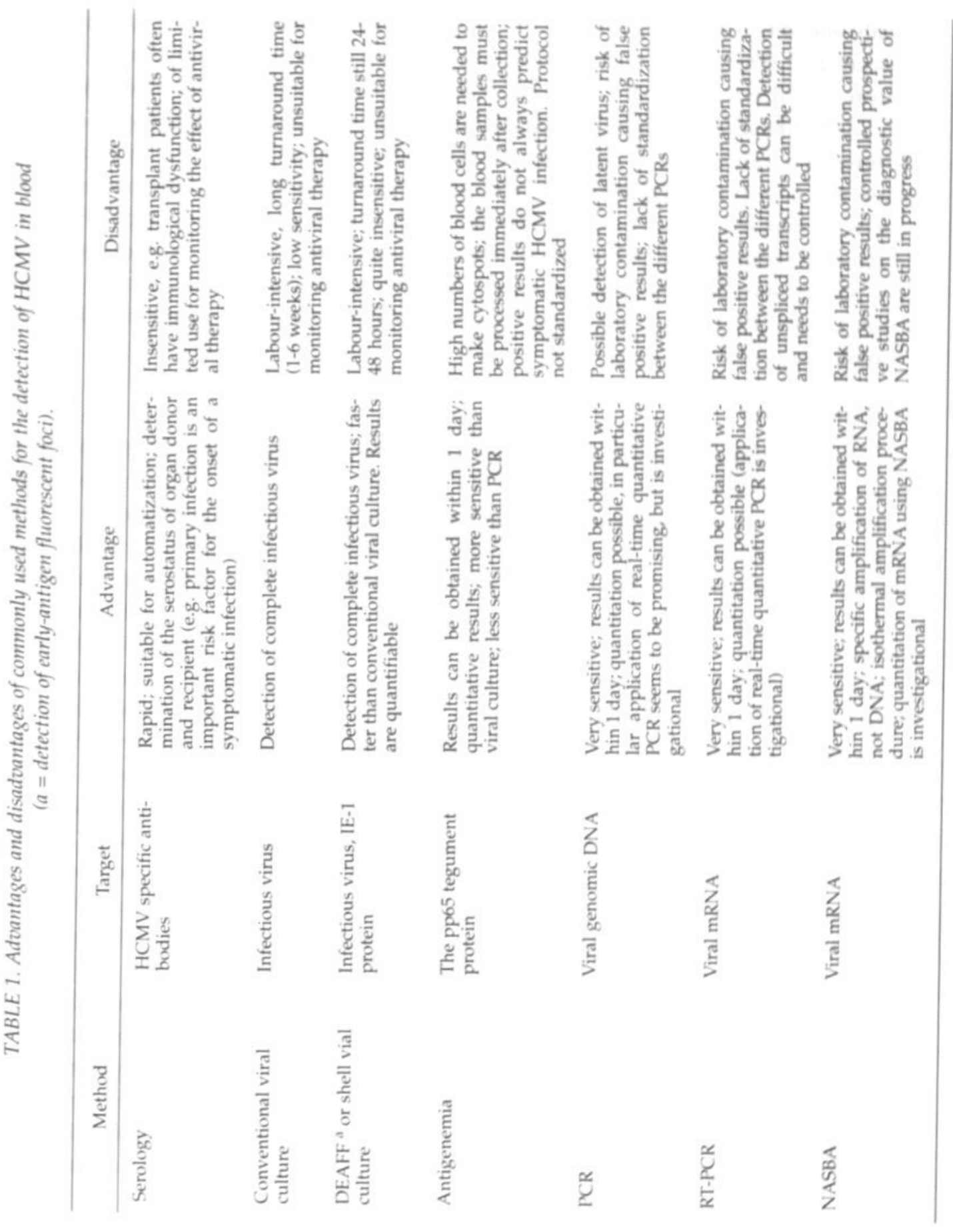


after only one or two days of culture (91). This technique is called detection of early antigen fluorescent foci (DEAFF) or shell vial culture. The monoclonal antibodies used in this procedure are directed against the IE-1 protein of the virus. The presence of infectious HCMV in the blood of immunocompromised individuals, as detected by the viral culture procedures, is a significant risk factor for the onset of symptomatic infection, especially in bone marrow transplant recipients $(162,179)$. However, due to the relatively low levels of infectious virus in blood and secretions, the sensitivity of both slow (detection of CPE) and rapid (DEAFF) viral culture techniques appears to be low $(184,198,248)$. In addition, viral culture results often become negative during therapy, regardless of the outcome of the infection $(20,65)$. Therefore, viral culture is also of limited value for monitoring HCMV infection during antiviral therapy.

\subsubsection{Antigenemia}

The pp65-antigenemia assay, developed by Van der Bij et al. (261) is used in many diagnostic laboratories for monitoring HCMV infections. This assay is performed with polymorphonuclear leukocytes (PMNL) which are isolated from blood samples of the patient and cytocentrifuged onto glass slides. The slides are subsequently used in an immunohistochemical procedure using monoclonal antibodies directed against the major early-late protein pp65 (56). The assay can be performed in one day and generates quantitative results, usually expressed as the number of pp65-antigen positive cells $/ 50 \mathrm{x}$ $10^{3}$ leukocytes. The major disadvantage of the antigenemia assay is that blood samples have to be processed in a short period of time ( 6 hours), in order to prevent a significant decrease in the number of positive cells $(23,229)$. In addition, the test may be difficult to perform after bone marrow or stem cell transplantation, or during a period of severe neutropenia, since high numbers of granulocytes are needed to make the cytospots.

It was recently demonstrated that the presence of HCMV antigens in PMNLs are not the result of a complete viral replication process, but are the result of a direct transmission of previously assembled infectious virus and synthesized viral material to PMNLs through a cell-to-cell contact mechanism with productively infected endothelial cells (86). Thus, the detection of pp65-antigen in circulating PMNLs is not a direct indicator of HCMV replication in vivo and therefore does not always predict the onset of symptomatic HCMV infection $(146,233,248,260)$. Nevertheless, high numbers of positive cells in blood samples obtained from solid organ transplant recipients appear to correlate well with a symptomatic HCMV infection $(87,89,93,253,260)$. This suggests that a cut-off value in the number of pp65-antigen positive cells may be used as a marker for initiation of preemptive therapy. Unfortunately, there does not appear to be a universal cut-off value, since it was found to 
double stranded DNA

5.

denaturation of DNA and

annealing of sequence specific primers

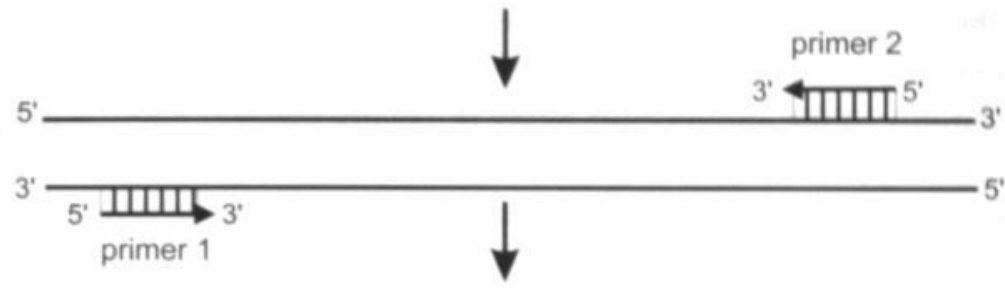

elongation by Taq DNA polymerase enzyme

5.

3.

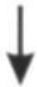

new cycle of denaturation, annealing and elongation

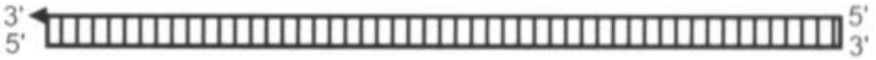

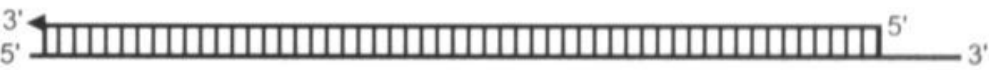

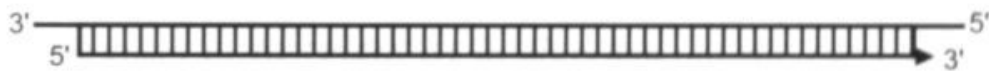

5.

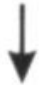

Logarithmic amplification of DNA by repetitive cycles of denaturation, annealing and elongation

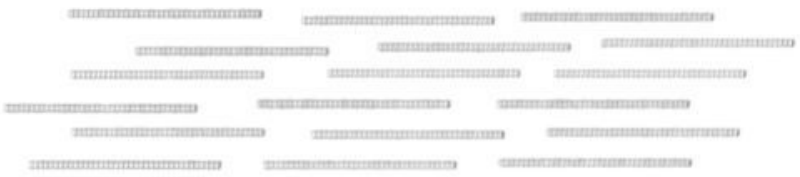

FIG. 3. Amplification of DNA by PCR. 
vary among different types of transplant patients and among different antigenemia protocols $(19,80,142,253)$. Furthermore, such a cut-off value is of limited value for allogeneic bone marrow transplant patients with severe GVHD. Rapid progression towards symptomatic HCMV infection in these patients requires the start of antiviral therapy upon the finding of the first antigenemia positive sample, even if the number of pp65-antigen positive cells in this sample is low (22).

In general, the antigenemia assay is more sensitive than viral culture for the detection of HCMV in blood $(85,146,261)$. Compared to the polymerase chain reaction (PCR, see below), the sensitivity of the antigenemia assay is usually lower $(22,85,253)$. Furthermore, antigenemia results appear to correlate well with the HCMV DNA content in both plasma and leukocytes as determined by quantitative PCR assays $(24,84,85)$. The antigenemia assay is also suitable for monitoring the effect of antiviral therapy, although intermittent rises in the number of pp65-antigen positive cells, which do not seem to correlate with clinical findings, are possible $(22,106,259)$. In addition, recurrence of antigenemia positive results after termination of antiviral therapy can predict the relapse of symptomatic HCMV infection (259).

\subsubsection{PCR}

With the polymerase chain reaction (PCR) it is possible to amplify low concentrations of DNA exponentially to levels which can easily be detected. This is achieved by repetitive cycles of denaturation of DNA, annealing of specific primers and DNA synthesis. Each of these steps requires a different temperature. Characteristic for this procedure is the use of the enzyme Taq DNA polymerase which can withstand the high temperatures used for denaturation of DNA. The procedure is outlined in more detail in Fig. 3. PCR was found to be a very sensitive assay for the detection of HCMV DNA in many studies. However, detection of HCMV DNA does not always predict the onset of symptomatic infection, because DNA of latent virus can be detected as well $(55,89,280)$. The determination of the viral load by means of quantitative PCR assays appears to be more predictive than qualitative PCR for the onset of symptomatic HCMV infection. Also, quantitative PCR is suitable for monitoring HCMV during antiviral therapy $(68,69,72,78,88,162,171,216,225$, 263,268 ). A disadvantage of most quantitative PCR assays is that they are very laborious and results are sometimes difficult to reproduce. Nevertheless, commercially available kits are relatively easy to perform $(24,26,57,119,135)$. Alternatively, the development of realtime PCR offers the possibility to determine the viral DNA load in a fast and convenient manner $(160,185,191,192,249,278)$. The preliminary results obtained with this technique appear to be promising. The equipment to perform these assays is (still) quite expensive, 
and standardized calibration methods need to be established. Nevertheless, it is expected that this approach will be become standard in more routine diagnostic laboratories.

Although HCMV is mainly a cell-associated virus, HCMV DNA can also be detected in cell-free body fluids, such as serum and plasma $(5,38,242)$. Most PCR methods are not standardized, which makes it difficult to compare the different studies in which the diagnostic value of PCR was evaluated. However, the detection of viral DNA in serum and plasma of solid organ transplant recipients appears to correlate better with symptomatic HCMV infection than detection of viral DNA in leukocytes, particularly in transplant recipients with secondary infections $(21,49,60,72,123)$. On the other hand, leukocytes may be more appropriate than plasma or serum for monitoring the effect of antiviral therapy, since residual viral DNA can be detected for a longer period of time in these cells (85).

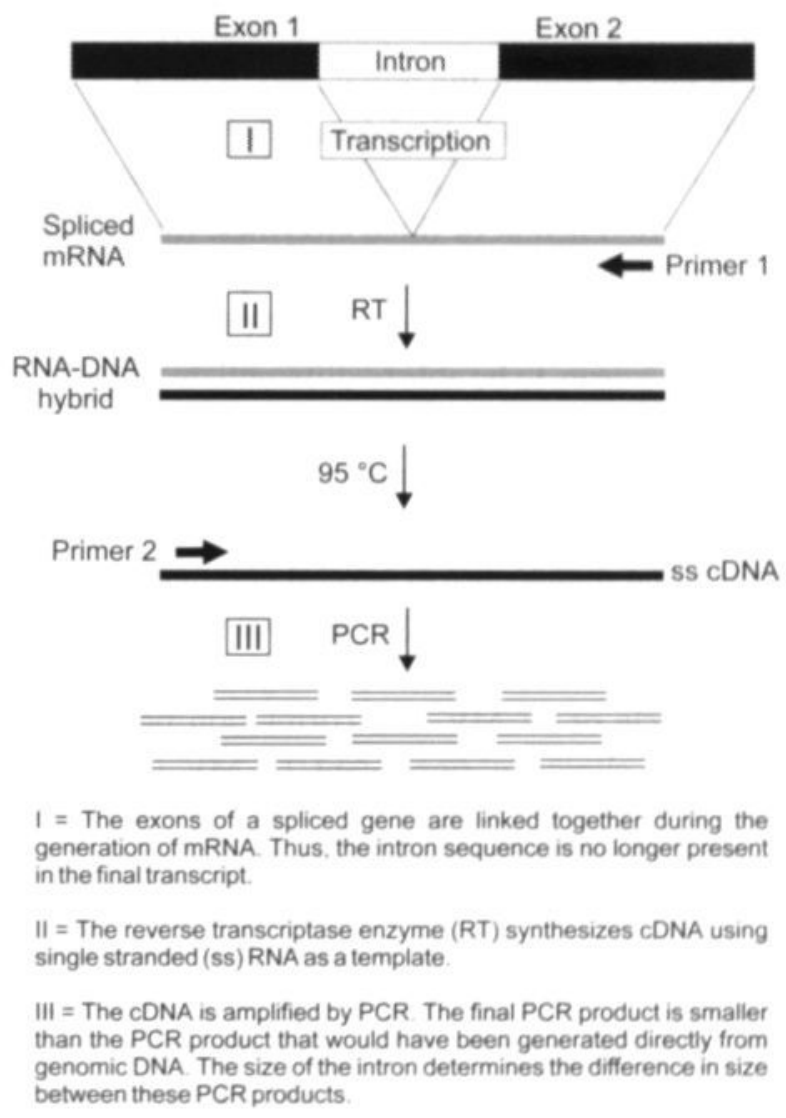

FIG. 4. Amplification of spliced mRNA by RT-PCR. 
Also, the detection of viral DNA in whole blood appeared to be a good marker for monitoring the effect of antiviral therapy in both bone marrow transplant recipients (67) and solid organ transplant recipients (255).

\subsubsection{RT-PCR and NASBA}

As discussed above, it is possible to detect DNA of latent virus with PCR. Positive PCR results are therefore not always correlated with the onset of a symptomatic HCMV infection. It was suggested that the demonstration of actively replicating virus by the detection of viral mRNA would correlate better with symptomatic infection (18). In particular, detection of late mRNA could allow the differentiation between latent and active infection because the former lacks the synthesis of structural proteins.

Two major techniques are available for the detection of mRNA: reverse transcriptase (RT)PCR and nucleic acid sequence-based amplification (NASBA). The detection of RNA by RTPCR has been outlined in Fig. 4. Briefly, the initial step in the RT-PCR procedure consists of the conversion of mRNA into cDNA performed by the RT enzyme. The cDNA is subsequently amplified by PCR. In contrast, NASBA is an isothermal amplification reaction which is based on the concerted action of three enzymes: ribonuclease H, RT and a DNAdependent RNA polymerase (Fig. 5) (47). The final product of this transcription-based amplification method is single-stranded RNA. RT-PCR has to be performed preferentially using primers which span an intron, to be able to differentiate amplified cDNA from genomic DNA (Fig. 4). In contrast, any single-stranded RNA can be used as a substrate in the NASBA reaction, which enables the detection of both spliced and unspliced transcripts in a background of DNA. NASBA and other transcription-based amplification methods have been used in both research and diagnostics of several pathogens, including HCMV (40).

RT-PCR and NASBA were used in various studies to detect HCMV IE, early or late mRNA in the blood of immunocompromised patients. These mRNAs represent different phases in the replication cycle of HCMV. The correlation between the presence of these mRNAs and the onset of a clinically significant HCMV infection was investigated as outlined below.

\subsubsection{Monitoring of IE mRNA expression}

Transcription of IE mRNA is one of the first events occurring in an HCMV-infected cell. Detection of this mRNA is therefore expected to be an early marker of infection. The UL123 mRNA, which encodes the IE-1 protein (246), was the main target for detection of IE transcription by RT-PCR $(18,143,150,174,176,200,211,264)$. However, the correlation between IE mRNA detection and the onset of symptomatic HCMV infection was found to vary considerably in different studies. The reported sensitivity of IE RT-PCR ranged from 


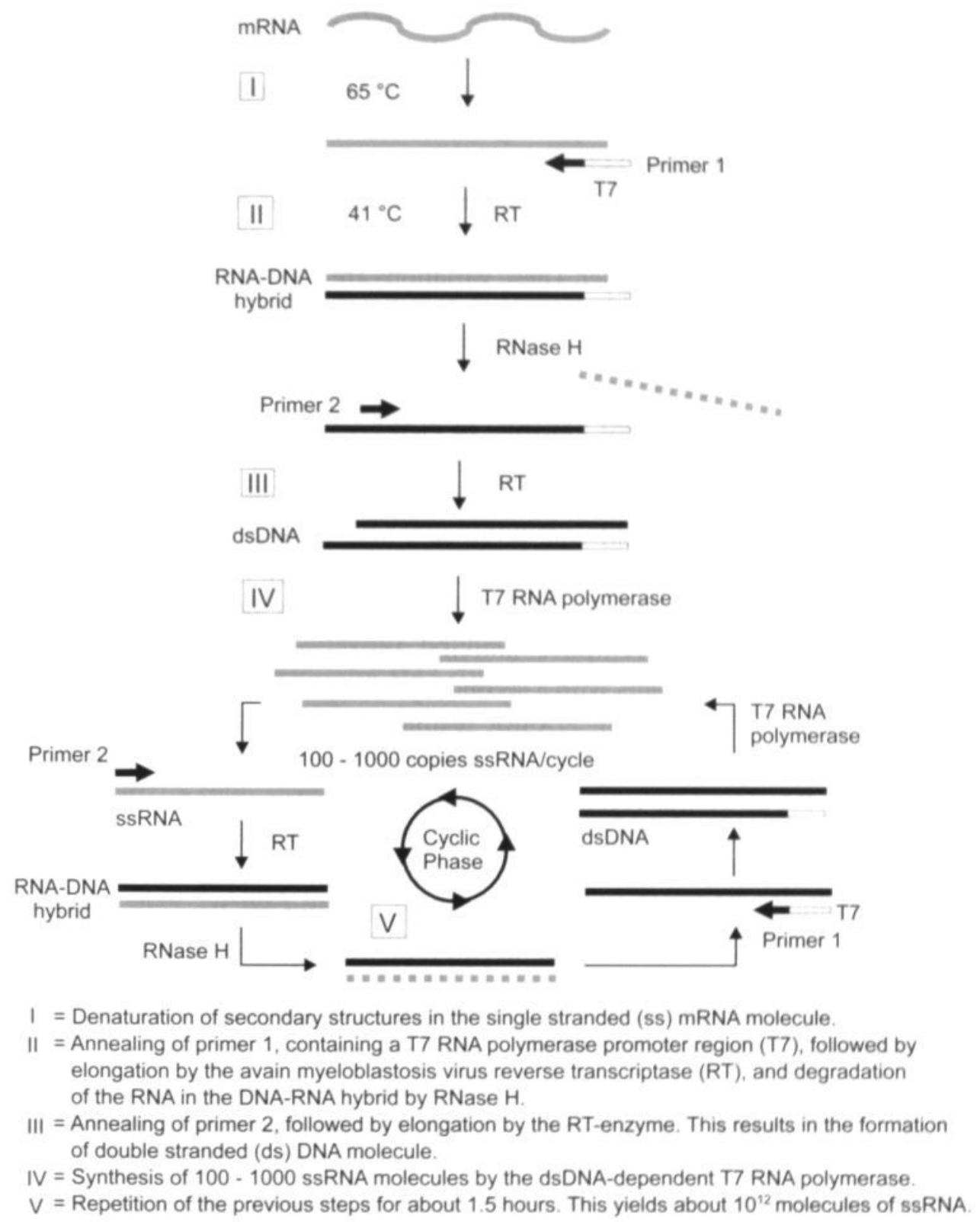

FIG. 5. Isothermal amplification of RNA by NASBA. 
$25 \%$ to $100 \%$. The low sensitivity of $25 \%$ was found in a study in which mononuclear cells were used for extraction of RNA (200). In all other studies whole blood or total leukocyte cell fractions were used. The specificity of IE RT-PCR was found to vary from $100 \%$ to $0 \%$. It was suggested that the low specificity of this assay was due to the detection of abortive infection, most probably induced by allogeneic stimulation of blood cells harbouring HCMV after blood transfusion (143, 180, 241). Compared to the antigenemia assay, the sensitivity of IE RT-PCR was found to be either similar $(18,176)$, higher $(143,264)$ or even lower (174). Compared to PCR, the sensitivity was found to be either similar $(18,264)$ or lower $(176,200,211)$, but never higher. These variations are most probably explained by the lack of standardization of the different RT-PCR methods that were used for the detection of IE mRNA.

Alternatively, a standardized NASBA assay was used for the detection of IE-1 mRNA in the blood of immunocompromised patients. IE NASBA was found to be more sensitive than the antigenemia assay, PCR and viral culture for detection of a HCMV infection in allogeneic bone marrow transplant recipients $(81,82)$. It was therefore suggested that IE- 1 mRNA detection by NASBA could well serve as a new parameter for the start of early preemptive therapy in bone marrow transplant recipients, since these patients are at high risk for the development of symptomatic infection. In contrast, IE NASBA was found not to be suitable for guiding preemptive antiviral treatment in solid organ transplant recipients, in particular in patients with a secondary infection $(81,82,194)$. Due to the high sensitivity of the assay, positive IE NASBA results obtained for these patients are not necessarily correlated with the onset of a symptomatic infection. Nevertheless, a quantitative NASBA assay was recently developed for monitoring IE-1 mRNA expression (102). It was shown that measuring the dynamics of the IE-1 RNA levels in blood samples of lung transplant patients with this assay is useful for monitoring disease progression (104). Quantification offers the possibility to determine cut-off levels for IE-1 mRNA expression that discriminate between asymptomatic infection and the onset of a symptomatic infection.

\subsubsection{Monitoring of early mRNA expression}

Only a few studies were reported in which the correlation between the detection of early mRNA and symptomatic infection was investigated. The detection of early UL112-113 mRNA appeared not to be unsuitable for monitoring symptomatic HCMV infection, due to low sensitivity and specificity of the assay (174). In contrast, detection of the same transcript was found to be a sensitive and specific marker for symptomatic infection when other primers were used and a nested RT-PCR protocol was performed (143). Moreover, early mRNA detection preceded pp65-antigen detection by at least 1 week for most 
patients. Similar results were obtained for the detection of the early B2.7 mRNA by NASBA $(4,194)$. In addition, detection of this transcript also appeared to be useful for monitoring HCMV infection during antiviral therapy. Nevertheless, additional studies should be performed to evaluate the diagnostic value of monitoring the expression of early mRNA expression.

\subsubsection{Monitoring of late mRNA expression}

As mentioned above, the detection of late mRNA could possibly allow the differentiation between latent and active infection because late mRNA is not likely to be expressed during latency. In the majority of the reported RT-PCR methods, either the UL32 mRNA, encoding the major tegument protein pp150 (125), or the ppUL86 mRNA, encoding the major capsid protein (MCP) (41), was detected. In addition, assays were developed for the detection of mRNA transcribed from the natural killer cell decoy gene UL18 $(112,113)$ and for mRNA transcribed from the R27080s gene, which codes for a protein of unknown function (212). Detection of MCP mRNA by RT-PCR appeared to be a sensitive and specific marker for symptomatic HCMV infection in organ transplant patients and AIDS patients $(80,95,96)$. In addition, MCP mRNA could be detected in most cases before the onset of a symptomatic HCMV infection $(80,95)$. Therefore, it appears to be a promising marker for the initiation of preemptive therapy. Similar results were found for monitoring the expression of the r27080s transcript $(143,190)$. In contrast, detection of pp150 mRNA or UL18 mRNA did not appear to be a very good marker for symptomatic infection. Due to the relatively low transcription rates of these transcripts, the sensitivity of the assays was low $(18,25,112,113,176)$.

NASBA was used for the detection of pp67 mRNA, which is one of the most abundantly transcribed late transcripts $(52,53)$. However, the antigenemia assay was found to be more sensitive than pp67 NASBA for the detection of symptomatic HCMV infection in renal transplant recipients (204). Furthermore, pp67 NASBA appeared to be inappropriate for a preemptive therapy approach in a group of bone marrow transplant recipients and solid organ transplant recipients with a primary infection, because the sensitivity was relatively low $(81,83)$. In contrast, it has been reported that pp 67 mRNA could be detected in all solid organ transplant recipients with a secondary infection $(82,83)$. These patients were treated preemptively with ganciclovir when $\geq 100$ pp65-antigen-positive cells per $2 \times 10^{5}$ leukocytes were detected in blood samples. The detection of pp67 mRNA preceded this antigenemia treshold level by a mean time of $3.5 \pm 2.6$ days. Similar findings were reported for thoracic organ transplant patients using a clinically relevant cut-off of $>10$ pp65-antigen-positive cells per $2 \times 10^{5}$ leukocytes (194). Nevertheless, cut-off values for the antigenemia assay are not commonly used and vary between different labs, most probably due to the lack of 
standardization of the assay. This may also underlie the apparent low sensitivity of the pp67 NASBA assay compared to the antigenemia assay in some reports.

In general, the detection of pp67 mRNA correlates strongly with the peak of infection Therefore, in contrast to the quantification of IE-1 mRNA using NASBA (see above) quantification of pp67 mRNA levels appears to have no additional value compared to the qualitative assay for the prediction of the possible onset of a symptomatic infection (104).

\subsubsection{Monitoring of antiviral therapy}

Monitoring of HCMV infection during antiviral therapy is necessary to determine a saft endpoint for discontinuation of the treatment. It was found that the clearance of HCMI mRNA from the blood after the start of antiviral therapy, corresponded with the disappearance of clinical symptoms $(18,25,80,143,174,176,190)$. In most cases, this wa: accompanied by the clearance of the pp65-antigen $(18,80,81,83,176)$ or infectious virus $(81$ 190). In contrast, PCR positive results usually outlasted clinical symptoms and antivira therapy for weeks $(18,25,80,176,190)$. Similar findings were reported for the detection o IE-1 mRNA using NASBA $(81,104)$. It was found that persistence of late mRNA during therapy, as well as renewed detection of late mRNA shortly after termination of therapy could indicate a reląpse of HCMV infection, either șmptomatic (80) or așvmptomatic (143 194). It should be noted that in most studies the follow-up after initiation of antiviral therapy was limited to a few samples or patients. In addition, these studies were retrospective studies, which implies that RT-PCR or NASBA results were not known at the time it was decided to initiate or terminate antiviral therapy. The true value of RT-PCR and NASBA in the management of antiviral therapy should therefore be investigated in prospective studies. These studies are currently in progress.

\subsection{Localization of CMV in blood cells during active infection}

In the previous part of the introduction, the diagnostic value of different assays for monitoring HCMV infection in the blood of immunocompromised patients was discussed. By separate analysis of the different blood cell populations of these patients, it was found that HCMV can be detected in the polymorphonuclear leukocytes (PMNLs) as well as in peripheral blood mononuclear cells (PBMCs) $(50,90,175,266)$. A higher load of virus appeared to be present in the PMNLs compared to the PBMCs, as determined by higher quantities of viral DNA $(224,225)$ and antigens $(90,101)$. In addition, infectious virus could be isolated more frequently from PMNLs than from monocytes $(90,224)$. However, as discussed above, it was recently shown that HCMV abortively infects PMNLs (86). Infectious virus or viral products in the PMNLs were found to be acquired from other 
permissive cells, e.g. infected endothelial cells, mainly by microfusion events with these cells. Therefore, it was concluded that the detection of virus or viral products in PMNLs preparations from immunocompromised patients with disseminated infection, e.g. pp65antigen detection by the antigenemia assay, cannot be considered as direct indicators of HCMV replication in blood cells (86).

In contrast to PMNLs, PBMCs were reported to be the major infected leukocyte cell type during acute infection. This was concluded from the finding that IE-1 mRNA and IE-1 protein could be detected predominantly in PBMCs $(99,257)$. Nevertheless, infection of these cells appears to be primarily abortive both in vivo $(224,232,257)$ and in vitro $(58,63$, $90,214)$. Thus, viral DNA and IE-1 mRNA can be detected in PBMCs but this is not necessarily correlated with the production and release of infectious progeny virus. Studies in which the presence of CMV in different PBMC populations was investigated showed that mainly monocytes could be infected in vitro $(148,240)$. HCMV DNA was rarely detected in lymphocytes $(50,90,266)$.

A possible confounding factor in the results described above for the presence of $\mathrm{CMV}$ in PBMCs and PMNLs, could be contamination of these fractions with circulating HCMVinfected endothelial cells (ECs). These cells were shown to contain viral transcripts and proteins from all three stages of the viral replication cycle, as well as numerous virus particles (98-100). Moreover, the number of CMV-infected ECs was reported to correlate with the severity of infection and presence of organ involvement in CMV infection (100, 205).

Like HCMV, MCMV is also associated with leukocytes during acute infection $(7,46,163$, 247). It is likely that CMV-infected cells circulating in the blood play a crucial role in the dissemination of the virus throughout the infected host. For example, after injection of MCMV in the tail veins of mice, infectious MCMV cannot only be recovered from whole blood, but also from bone marrow, spleen, lungs, and salivary glands during the acute phase of infection (277). Similarly, active replication of HCMV is not restricted to blood cells and can occur in various organs of immunocompromised patients. In particular, transplanted organs appear to be frequently involved in CMV infection (233).

\subsection{Localization of CMV during latent infection}

In contrast to HCMV infections of immunocompromised patients, infections of healthy individuals usually remain asymptomatic. Like all other herpesviruses, CMV can cause acute, persistent and life-long latent infections. Nevertheless, exact sites of viral latency or persistence remain to be defined. In general, the term latency is used when genomic CMV 
DNA is present, while infectious virus cannot be detected. Detection of low leve production of infectious virus is usually described as persistence. Thus, the distinction between latency and persistence has primarily relied on the sensitivity of the assays that are used to detect infectious virus.

CMV can usually not be isolated from the blood of healthy donors $(250,251)$. Nevertheless, CMV can be transmitted by blood transfusion, and leukocyte depletion reduces the incidence of infection (147). It is therefore likely that CMV is present in the blood in a latent form. It was found that CD14+ monocytes are a major site of latency, in contrast to PMNLs and lymphocytes $(250,251)$. In latently-infected monocytes, the viral genome appears to be present as a circular plasmid, similarly as described for other herpesviruses (27). HCMV IE, early and late gene transcription could not be detected in freshly isolated monocytes from healthy HCMV seropositive individuals, although HCMV DNA was readily detected in these cells (252). Similar findings were reported for MCMV (206). Because monocytes circulate in the blood only for several hours and infectious virus is not isolated from the blood during latent infection, it is unlikely that the monocytes have obtained the virus by primary infection in the blood circulation. It was therefore suggested that bone marrow progenitor cells may act as a reservoir for HCMV and can transmit the viraf genome to peripheraf bibod' monocytes, in the absence of lytic gene expressiorr (ifi', $182,277,279)$. This theory is supported by the finding that bone marrow cells obtained from healthy seropositive individuals appear to be a site of latency $(133,170,182)$. In particular, cells which express the myeloid surface markers CD14, CD15 and CD33 along with the dendritic markers CD1a and CD10 contained HCMV DNA $(110,133)$. These cells serve as progenitors for monocytes. The dendritic cells and cells of the monocytic lineage play an important role in the immune system as antigen presenting cells (APCs). The predominant presence of latent CMV in these cells is expected to play a key role in the ability of CMV to evade the immune system of the host and to prevent its own eradication. In fact, it was found that HCMV gene products interfere with the activation of MHC class I- and class IIrestricted $\mathrm{T}$ cells, modify the function of cytokines and their receptors, interact with complement factors and modulate signal transduction and transcription factor activity (157). Furthermore, viral mRNAs transcribed from the immune evasion genes US3, US6, US11 were found to be actively expressed in blood during the acute phase of infection as well as after clinical recovery (103). It was therefore suggested that these genes may play a role in the long-term control of HCMV infection in vivo.

Interestingly, a novel class of HCMV transcripts was detected in experimentally and naturally infected hematopoietic progenitor cells. These transcripts appear to be produced exclusively during latent infection $(110,133,134,236)$. In addition, antibodies directed 
against the proteins encoded by these transcripts have been detected in serum from healthy seropositive blood donors (134, 145) and patients with active HCMV infection (145). However, it was reported that at least one of the latency-associated proteins is dispensable for both productive and latent HCMV infection (271). Furthermore, these transcripts were recently also shown to be expressed in a variety of HCMV-infected cell types during productive infection in vitro (159). Thus, until now the function of the latency-associated transcripts and their encoded proteins is still enigmatic.

In vitro infection of bone marrow progenitor cells resulted in the spread of the virus through the progeny of these cells as they replicate and differentiate (161). Permissiveness of bone marrow progenitor cells for productive infection appeared to be dependent on their state of differentiation. Early after infection of the progenitor cells, infectious virus could not be detected in the supernatant of the culture (279). Moreover, IE and late gene products were absent at that time. However, differentiation of the bone marrow cells resulted in productive CMV infection. This is consistent with the observation that HCMV replication and gene expression in monocytes could be stimulated upon differentiation of these cells into macrophages using granulocyte colony stimulating factor or hydrocortisone $(124,151$, 252). Moreover, full virus replication could be demonstrated after in vitro allogeneic stimulation of latently infected peripheral blood mononuclear cells (241). Thus, immune activation can provide a stimulus which is sufficient for complete reactivation of HCMV. In this respect, cytokines are thought to play an important role. For example, TNF-alpha is able to stimulate the activity of the CMV IE enhancer/promoter region in the human monocytic cell line, HL-60 $(76,245)$. Also, for MCMV it was found that macrophages are able to support complete virus replication $(31,129,181)$. Thus, blood cell progenitors in the bone marrow may act as the main source of latent CMV. The virus can reactivate and disseminate from the bone marrow to other organs via monocytes as they leave the circulation and undergo tissue-specific differentiation to macrophages $(206,247)$.

In addition to the findings of latent CMV in the bone marrow, latent MCMV was reported to be present in various other organs. Moreover, it was hypothesized that cells of the myeloid lineage are only a temporary site of CMV latency and that long-lived stromal and/or parenchymal cells are the cellular site of prolonged latency in organs (140). This theory is supported by the finding that virus is eventually cleared from the blood $(9,10)$. In addition, mature lymphocytes, macrophages, or dendritic cells did not appear to be sites of latency in spleens of latently infected mice (172). Determination of sites of latency or persistence of HCMV in organs of healthy humans has been difficult to perform because of the limited availability of tissue samples. To circumvent this problem, samples were obtained from previously healthy trauma victims. In these samples, CMV DNA and 
antigens could be detected in brain, kidney, spleen, lung, liver and arteries (114, 115, 169, 254). Like HCMV DNA, MCMV DNA could be detected in a variety of organs such as heart, kidney, liver, lung, spleen, brain and salivary gland during latent infection $(45,131,208$, 231). Latent virus could be reactivated from these organs by prolonged co-culturing with permissive cells or by transplantation of tissue to seronegative recipients or SCID mice (42, $111,172,207,223,230,277$ ).

In most studies it was demonstrated that little or no infectious virus is present in organs of chronically infected mice, except in the salivary glands $(10,16,127,128,132,168,172)$. This indicated that the long-term presence of MCMV in mice does not require continuous low level production of infectious virus. Nevertheless, IE- 1 and early-late pp 50 mRNA have been detected in latently infected spleens $(116,276)$, lungs $(139,277)$ and salivary glands $(16,276)$, suggesting that there can be some viral trancriptional activity in the absence of detectable levels of infectious virus. Interestingly, upon induction of immunosuppression in latently infected mice by gamma-irradiation, a switch from focal to generalized IE-1 transcription was found to occur in the lungs (140). In addition, late IE-3 and gB transcripts were generated (141). Nevertheless, infectious virus was not necessarily detected together with late mRNA expression. It was therefore proposed that several sequentially ordered control points exist in the transition from MCMV latency to recurrence, at least in the lungs.

\subsection{Rat CMV}

The rat cytomegalovirus (RCMV) infection model proved to be valuable for studying aspects of CMV infection in relation to organ transplantation $(130,152,165,275)$. Compared to mice, rats are more convenient in transplantation studies, because the organs of rats are easier to handle during surgical procedures than those of mice. The isolation of the Maastricht strain of RCMV from wild rats was reported by Bruggeman et al. in 1982 (35). At about the same time, the English strain of RCMV was isolated by Priscott and Tyrrell (210). However, the two RCMV strains appear to represent different betaherpesvirus species rather than strains (12). This conclusion was based on the results of the comparison of the genomic sequences comprising the major immediate-early genes. The availability of sequences of the English strain is very limited $(226,227)$. In contrast, the complete genomic sequence of the Maastricht strain was recently determined and compared to that of HCMV and MCMV (265). The RCMV genome was found to have counterparts of all but one of the open reading frames that are conserved between MCMV and HCMV.

The pathogenesis of RCMV infection in rats was found to be similar to that of HCMV infection in humans (244). Typically, infection of immunocompetent rats with RCMV is 
usually not life-threatening $(34,244)$, even when a high dose of virus is used $(33,34)$. In contrast, induction of immunosuppression by gamma-irradiation before RCMV infection results in high mortality rates (244). During the first week after primary infection of rats with RCMV, infectious virus can be isolated from most organs, except the salivary glands $(14,34,244)$. In general, no infectious virus can be isolated from the salivary glands before day 10, although RCMV DNA can be detected in this organ as early as day 3 (14). In the following weeks, virus titers increase in this organ up to 28 days post infection (p.i.), whereas infectious virus can no longer be detected in the other organs. Nevertheless, studies in which latently infected renal allografts were transplanted to seronegative rats, showed that virus could reactivate from these organs $(36,37)$. Similar findings were reported with cardiac allografts, although virus reactivated less frequently compared to the renal allografts (36). Apparently, the presence of RCMV in organs of latently infected rats needed to be further characterized, in particular at the level of RCMV DNA and viral mRNA expression. In a preliminary study, RCMV DNA could be detected with a high frequency in salivary glands and liver at 330 days after infection (13). Incidentally, DNA could also be detected in kidney, lungs, pancreas, and thymus at that time-point. However, these studies did not include a similar analysis during acute infection, nor was the expression of viral mRNA determined.

\subsection{Aims of the thesis}

Preemptive therapy approach is a promising concept in the management of HCMV infection following organ transplantation, although it strongly depends on a sensitive assay with a high positive predictive value for the onset of symptomatic infection $(62,221)$. PCR as well as the antigenemia assay appear to be helpful in early diagnosis of active HCMV infection. However, with PCR it is possible to detect latent virus which is not necessarily correlated with the onset of a symptomatic infection $(55,89,280)$. The antigenemia assay is a relatively sensitive method for the detection of HCMV infection, although positive results do not always predict the onset of a symptomatic HCMV infection $(146,233,248,260)$. It was suggested that the demonstration of actively replicating virus by the detection of viral mRNA would correlate better with symptomatic infection (18).

The first aim of this thesis was to evaluate the diagnostic value of monitoring the expression of HCMV pp67 and IE-1 mRNA in blood samples using NASBA, as markers for HCMV infection in kidney and liver transplant patients. The NASBA assays were compared to assays which are routinely used in the laboratory, such as the antigenemia assay, viral culture and serology. The results obtained with pp67 NASBA and IE NASBA for 


\section{CHAPTER 1}

kidney transplant patients are described in chapter 2 and 3 , respectively. These were the first published reports on the technical procedure of the NASBA assays and their diagnostic value. The evaluation of the pp67 and IE NASBA assay for monitoring HCMV infection in liver transplant patients is presented in chapter 4 . Together with the published data for other organ transplant patients, the suitability of IE and pp67 NASBA for monitoring HCMV infection is discussed in chapter 6.

Monitoring of immunocompromised patients for the onset of HCMV infection is usually performed by screening blood samples for the presence of infectious virus or viral constituents. However, CMV infection is not restricted to the blood compartment, since various organs can be involved in an active CMV infection (233). The fact that $\mathrm{CMV}$ can be transmitted by organ transplantation from seropositive donors, indicates that $\mathrm{CMV}$ also resides in organs from immunocompetent individuals. It is virtually impossible to perform extensive studies on active and latent CMV infection in human organs, because the availability of tissue biopsies is usually limited to transplanted organs or organs obtained after autopsy. In the latter organs, the integrity of the purified RNA is usually questionable due to post-mortem changes in the cellular environment. This RNA is therefore unsuitable to perform reliable expression studies. Alternatively, infection of rats with RCMV proved to be a convenient animal model to study aspects of CMV infection in relation to organ transplantation $(130,152,165,275)$. The molecular biology as well as the in vitro and in vivo growth characteristics were found to be highly similar between RCMV and HCMV $(34,244$, 265). Nevertheless, as for HCMV, the mechanisms which play a role in the maintenance of a latent RCMV infection are still unclear. Therefore, the second aim of this thesis was to obtain a more detailed picture of acute and latent RCMV infections in vivo. For this purpose, immunocompetent rats were infected and subsequently sacrificed at defined time points after infection. The presence of RCMV genomic DNA, mRNA, and infectious virus in various tissues and blood was determined. As a result, viral replication and transcriptional activity during acute, persistent and latent infection could be defined (chapter 5). These data as well as the findings from other studies are discussed in chapter 6. 


\section{REFERENCES}

1. Aguado, J. M., M. A. Gomez Sanchez, C. Lumbreras, J. Delgado, M. Lizasoain, J. R. Otero, J. J. Rufilanchas, and A. R. Noriega. 1995. Prospective randomized trial of efficacy of ganciclovir versus that of anti-cytomegalovirus (CMV) immunoglobulin to prevent CMV disease in CMVseropositive heart transplant recipients treated with OKT3. Antimicrob. Agents Chemother. 39:1643-1645.

2. Ahsan, N., M. J. Holman, and H. C. Yang. 1997. Efficacy of oral ganciclovir in prevention of cytomegalovirus infection in post-kidney transplant patients. Clin. Transplant. 11:633-639.

3. Alain, S., P. Honderlick, D. Grenet, M. Stern, C. Vadam, M. J. Sanson Le Pors, and M. C. Mazeron. 1997. Failure of ganciclovir treatment associated with selection of a ganciclovirresistant cytomegalovirus strain in a lung transplant recipient. Transplantation. 63:1533-1536.

4. Aono, T., K. Kondo, H. Miyoshi, K. Tanaka Taya, M. Kondo, Y. Osugi, J. Hara, S. Okada, and K. Yamanishi. 1998. Monitoring of human cytomegalovirus infections in pediatric bone marrow transplant recipients by nucleic acid sequence-based amplification. J. Infect. Dis. 178:1244-1249.

5. Aspin, M. M., G. M. Gallez Hawkins, T. D. Giugni, B. Tegtmeier, D. J. Lang, G. M. Schmidt, S. J. Forman, and J. A. Zaia. 1994. Comparison of plasma PCR and bronchoalveolar lavage fluid culture for detection of cytomegalovirus infection in adult bone marrow transplant recipients. J. Clin. Microbiol. 32:2266-2269.

6. Bailey, T. C., E. P. Trulock, N. A. Ettinger, G. A. Storch, J. D. Cooper, and W. G. Powderly. 1992. Failure of prophylactic ganciclovir to prevent cytomegalovirus disease in recipients of lung transplants. J. Infect. Dis. 165:548-552.

7. Bale, J. F., Jr., and M. E. O'Neil. 1989. Detection of murine cytomegalovirus DNA in circulating leukocytes harvested during acute infection of mice. J. Virol. 63:2667-2673.

8. Balfour, H. H., Jr., B. A. Chace, J. T. Stapleton, R. L. Simmons, and D. S. Fryd. 1989. A randomized, placebo-controlled trial of oral acyclovir for the prevention of cytomegalovirus disease in recipients of renal allografts. N. Engl. J. Med. 320:1381-1387.

9. Balthesen, M., L. Dreher, P. Lucin, and M. J. Reddehase. 1994. The establishment of cytomegalovirus latency in organs is not linked to local virus production during primary infection. J. Gen. Virol. 75:2329-2336.

10. Balthesen, M., M. Messerle, and M. J. Reddehase. 1993. Lungs are a major organ site of cytomegalovirus latency and recurrence. J. Virol. 67:5360-5366.

11. Barkholt, L. M., A. Ehrnst, and B. Veress. 1994. Clinical use of immunohistopathologic methods for the diagnosis of cytomegalovirus hepatitis in human liver allograft biopsy specimens. Scand. J. Gastroenterol. 29:553-560.

12. Beisser, P. S., S. J. Kaptein, E. Beuken, C. A. Bruggeman, and C. Vink. 1998. The Maastricht strain and England strain of rat cytomegalovirus represent different betaherpesvirus species rather than strains. Virology. 246:341-351.

13. Beisser, P. S., J. S. Kloover, G. E. Grauls, M. J. Blok, C. A. Bruggeman, and C. Vink. 2000. The r144 major histocompatibility complex class I-like gene of rat cytomegalovirus is dispensable for both acute and long-term infection in the immunocompromised host. J. Virol. 74:1045-1050. 
14. Beisser, P. S., C. Vink, J. G. Van Dam, G. Grauls, S. J. Vanherle, and C. A. Bruggeman. 1998. The R33 G protein-coupled receptor gene of rat cytomegalovirus plays an essential role in the pathogenesis of viral infection. J. Virol. 72:2352-2363.

15. Best, N. G., A. K. Trull, K. K. Tan, D. J. Spiegelhalter, T. G. Wreghitt, and J. Wallwork. 1995. Blood cyclosporine concentrations and cytomegalovirus infection following heart transplantation. Transplantation. 60:689-694.

16. Bevan, I. S., C. C. Sammons, and C. Sweet. 1996. Investigation of murine cytomegalovirus latency and reactivation in mice using viral mutants and the polymerase chain reaction. J. Med. Virol. 48:308-320.

17. Bienvenu, B., E. Thervet, J. Bedrossian, C. Scieux, M. C. Mazeron, D. Thouvenot, and C. Legendre. 2000. Development of cytomegalovirus resistance to ganciclovir after oral maintenance treatment in a renal transplant recipient. Transplantation. 69:182-184.

18. Bitsch, A., H. Kirchner, R. Dupke, and G. Bein. 1993. Cytomegalovirus transcripts in peripheral blood leukocytes of actively infected transplant patients detected by reverse transcriptionpolymerase chain reaction. J. Infect. Dis. 167:740-743.

19. Boeckh, M., and G. Boivin. 1998. Quantitation of cytomegalovirus: methodologic aspects and clinical applications. Clin. Microbiol. Rev. 11:533-554.

20. Boeckh, M., R. A. Bowden, J. M. Goodrich, M. Pettinger, and J. D. Meyers. 1992. Cytomegalovirus antigen detection in peripheral blood leukocytes after allogeneic marrow transplantation. Blood. 80:1358-1364.

21. Boeckh, M., G. M. Gallez Hawkins, D. Myerson, J. A. Zaia, and R. A. Bowden. 1997. Plasma polymerase chain reaction for cytomegalovirus DNA after allogeneic marrow transplantation: comparison with polymerase chain reaction using peripheral blood leukocytes, pp65 antigenemia, and viral culture. Transplantation. 64:108-113.

22. Boeckh, M., T. A. Gooley, D. Myerson, T. Cunningham, G. Schoch, and R. A. Bowden. 1996. Cytomegalovirus pp65 antigenemia-guided early treatment with ganciclovir versus ganciclovir at engraftment after allogeneic marrow transplantation: a randomized double-blind study. Blood. 88:4063-4071.

23. Boeckh, M., P. M. Woogerd, T. Stevens Ayers, C. G. Ray, and R. A. Bowden. 1994. Factors influencing detection of quantitative cytomegalovirus antigenemia. J. Clin. Microbiol. 32:832-834.

24. Boivin, G., J. Handfield, G. Murray, E. Toma, R. Lalonde, J. G. Lazar, and M. G. Bergeron. 1997. Quantitation of cytomegalovirus (CMV) DNA in leukocytes of human immunodeficiency virusinfected subjects with and without CMV disease by using PCR and the SHARP Signal Detection System. J. Clin. Microbiol. 35:525-526.

25. Boivin, G., J. Handfield, E. Toma, R. Lalonde, and M. G. Bergeron. 1999. Expression of the late cytomegalovirus (CMV) pp150 transcript in leukocytes of AIDS patients is associated with a high viral DNA load in leukocytes and presence of CMV DNA in plasma. J. Infect. Dis. 179:1101-1117.

26. Boivin, G., J. Handfield, E. Toma, G. Murray, R. Lalonde, V. J. Tevere, R. Sun, and M. G. Bergeron. 1998. Evaluation of the AMPLICOR cytomegalovirus test with specimens from human immunodeficiency virus-infected subjects. J. Clin. Microbiol. 36:2509-2513. 
27. Bolovan Fritts, C. A., E. S. Mocarski, and J. A. Wiedeman. 1999. Peripheral blood CD14(+) cells from healthy subjects carry a circular conformation of latent cytomegalovirus genome. Blood. 93:394-398.

28. Boriskin, Y. S., J. C. Booth, C. M. Corbishley, B. P. Madden, W. J. McKenna, A. J. Murday, and H. M. Steel. 1996. Human cytomegalovirus and acute rejection after heart transplantation are not directly associated. J. Med. Virol. 50:59-70.

29. Bowden, R. A., M. Mori, S. Dobbs, R. Hackman, K. Kopecky, and S. Crawford. 1993. Mononuclear cell reconstitution in the lung after marrow transplantation. Lack of influence of cytomegalovirus pneumonia, irradiation, and graft-versus-host disease. Transplantation. 55:557561.

30. Bowden, R. A., S. J. Slichter, M. Sayers, D. Weisdorf, M. Cays, G. Schoch, M. Banaji, R. Haake, K. Welk, L. Fisher, and et al. 1995. A comparison of filtered leukocyte-reduced and cytomegalovirus (CMV) seronegative blood products for the prevention of transfusionassociated CMV infection after marrow transplant. Blood. 86:3598-3603.

31. Brautigam, A. R., F. J. Dutko, L. B. Olding, and M. B. Oldstone. 1979. Pathogenesis of murine cytomegalovirus infection: the macrophage as a permissive cell for cytomegalovirus infection, replication and latency. J. Gen. Virol. 44:349-359.

32. Britt, W. J., L. Vugler, E. J. Butfiloski, and E. B. Stephens. 1990. Cell surface expression of human cytomegalovirus (HCMV) gp55-116 (gB): use of HCMV-recombinant vaccinia virusinfected cells in analysis of the human neutralizing antibody response. J. Virol. 64:1079-1085.

33. Bruggeman, C. A., W. M. Debie, G. Grauls, G. Majoor, and C. P. van Boven. 1983. Infection of laboratory rats with a new cytomegalo-like virus. Arch. Virol. 76:189-199.

34. Bruggeman, C. A., H. Meijer, F. Bosman, and C. P. van Boven. 1985. Biology of rat cytomegalovirus infection. Intervirology. 24:1-9.

35. Bruggeman, C. A., H. Meijer, P. H. Dormans, W. M. Debie, G. E. Grauls, and C. P. van Boven. 1982. Isolation of a cytomegalovirus-like agent from wild rats. Arch. Virol. 73:231-241.

36. Bruning, J. H., C. A. Bruggeman, C. P. van Boven, and P. J. van Breda Vriesman. 1986. Passive transfer of cytomegalovirus by cardiac and renal organ transplants in a rat model. Transplantation. 41:695-698.

37. Bruning, J. H., C. A. Bruggeman, and P. J. van Breda Vriesman. 1989. Transfer of cytomegalovirus infection via renal allografts: role of immunosuppressive regimens on the transfer rate, and effect of cytomegalovirus infections on renal allograft rejection; study in a rat model. Transplant. Proc. 21:2089-2090.

38. Brytting, M., W. Xu, B. Wahren, and V. A. Sundqvist. 1992. Cytomegalovirus DNA detection in sera from patients with active cytomegalovirus infections. J. Clin. Microbiol. 30:1937-1941.

39. Cagle, P. T., G. Buffone, V. A. Holland, T. Samo, G. J. Demmler, G. P. Noon, and E. C. Lawrence. 1992. Semiquantitative measurement of cytomegalovirus DNA in lung and heart-lung transplant patients by in vitro DNA amplification. Chest. 101:93-96.

40. Chan, A. B., and J. D. Fox. 1999. NASBA and other transcription-based amplification methods for research and diagnostic microbiology. Rev. Med. Microbiol. 10 (4):185-196.

41. Chee, M., S. A. Rudolph, B. Plachter, B. Barrell, and G. Jahn. 1989. Identification of the major capsid protein gene of human cytomegalovirus. J. Virol. 63:1345-1353. 
42. Cheung, K. S., and D. J. Lang. 1977. Detection of latent cytomegalovirus in murine salivary and prostate explant cultures and cells. Infect. Immun. 15:568-574.

43. Cohen, A. T., J. G. O'Grady, S. Sutherland, R. Sallie, K. C. Tan, and R. Williams. 1993. Controlled trial of prophylactic versus therapeutic use of ganciclovir after liver transplantation in adults. J. Med. Virol. 40:5-9.

44. Colina, F., N. T. Juca, E. Moreno, C. Ballestin, J. Farina, M. Nevado, C. Lumbreras, and R. Gomez Sanz. 1995. Histological diagnosis of cytomegalovirus hepatitis in liver allografts. J. Clin. Pathol. 48:351-357.

45. Collins, T., C. Pomeroy, and M. C. Jordan. 1993. Detection of latent cytomegalovirus DNA in diverse organs of mice. J. Infect. Dis. 168:725-729.

46. Collins, T. M., M. R. Quirk, and M. C. Jordan. 1994. Biphasic viremia and viral gene expression in leukocytes during acute cytomegalovirus infection of mice. J. Virol. 68:6305-6311.

47. Compton, J. 1991. Nucleic acid sequence-based amplification. Nature. 350:91-92.

48. Crumpacker, C. S. 1996. Ganciclovir. N. Engl. J. Med. 335:721-729.

49. Cunningham, R., A. Harris, A. Frankton, and W. Irving. 1995. Detection of cytomegalovirus using PCR in serum from renal transplant recipients. J. Clin. Pathol. 48:575-577.

50. Dankner, W. M., J. A. McCutchan, D. D. Richman, K. Hirata, and S. A. Spector. 1990. Localization of human cytomegalovirus in peripheral blood leukocytes by in situ hybridization. J. Infect. Dis. 161:31-36.

51. Danner, S. A. 1995. Management of cytomegalovirus disease. Aids. 9 Suppl. 2:S3-S8.

52. Davis, M. G., and E.-S. Huang. 1985. Nucleotide sequence of a human cytomegalovirus DNA fragment encoding a 67 -kilodalton phosphorylated viral protein. J. Virol. 56:7-11.

53. Davis, M. G., E.-C. Mar, Y.-M. Wu, and E.-S. Huang. 1984. Mapping and expression of a human cytomegalovirus major viral protein. J. Virol. 52:129-135.

54. DeArmond, B. 1991. Safety considerations in the use of ganciclovir in immunocompromised patients. Transplant Proc. 23:26-29.

55. Delgado, R., C. Lumbreras, C. Alba, M. A. Pedraza, J. R. Otero, R. Gomez, E. Moreno, A. R. Noriega, and C. V. Paya. 1992. Low predictive value of polymerase chain reaction for diagnosis of cytomegalovirus disease in liver transplant recipients. J. Clin. Microbiol. 30:1876-1878.

56. Depto, A. S., and R. M. Stenberg. 1989. Regulated expression of the human cytomegalovirus pp65 gene: octamer sequence in the promoter is required for activation by viral gene products. J. Virol. 63:1232-1238.

57. DiDomenico, N., H. Link, R. Knobel, T. Caratsch, W. Weschler, Z. G. Loewy, and M. Rosenstraus. 1996. COBAS AMPLICOR: fully automated RNA and DNA amplification and detection system for routine diagnostic PCR. Clin. Chem. 42:1915-1923.

58. Dudding, L. R., and H. M. Garnett. 1987. Interaction of strain AD169 and a clinical isolate of cytomegalovirus with peripheral monocytes: the effect of lipopolysaccharide stimulation. J. Infect. Dis. 155:891-896.

59. Dunn, D. L., K. J. Gillingham, M. A. Kramer, W. J. Schmidt, A. Erice, H. H. Balfour, Jr., P. F. Gores, R. W. Gruessner, A. J. Matas, W. D. Payne, and et al. 1994. A prospective randomized study of acyclovir versus ganciclovir plus human immune globulin prophylaxis of cytomegalovirus infection after solid organ transplantation. Transplantation. 57:876-884. 
60. Eckart, P., J. Brouard, A. Vabret, F. Freymuth, M. Guillot, J. P. Ryckelynck, and B. Hurault de Ligny. 1997. Detection of human cytomegalovirus in renal transplantation: comparison of four diagnostic methods: DNA in sera by polymerase chain reaction (PCR), DNA in leukocyte by PCR, pp65 leukocytic antigenemia, and viremia. Transplant. Proc. 29:2387-2389.

61. Eckhoff, D. E., B. M. McGuire, L. R. Frenette, J. L. Contreras, S. L. Hudson, and J. S. Bynon. 1998. Tacrolimus (FK506) and mycophenolate mofetil combination therapy versus tacrolimus in adult liver transplantation. Transplantation. 65:180-187.

62. Egan, J. J., J. Lomax, L. Barber, S. S. Lok, R. Martyszczuk, N. Yonan, A. Fox, A. K. Deiraniya, A. J. Turner, and A. A. Woodcock. 1998. Preemptive treatment for the prevention of cytomegalovirus disease: in lung and heart transplant recipients. Transplantation. 65:747-752.

63. Einhorn, L., and A. Ost. 1984. Cytomegalovirus infection of human blood cells. J. Infect. Dis. 149:207-214.

64. Einsele, H., G. Ehninger, M. Steidle, I. Fischer, S. Bihler, F. Gerneth, A. Vallbracht, H. Schmidt, H. D. Waller, and C. A. Muller. 1993. Lymphocytopenia as an unfavorable prognostic factor in patients with cytomegalovirus infection after bone marrow transplantation. Blood. 82:1672-1678.

65. Einsele, H., G. Ehninger, M. Steidle, A. Vallbracht, M. Muller, H. Schmidt, J. G. Saal, H. D. Waller, and C. A. Muller. 1991. Polymerase chain reaction to evaluate antiviral therapy for cytomegalovirus disease. Lancet. 338:1170-1172.

66. Einsele, H., H. Hebart, C. Kauffmann Schneider, C. Sinzger, G. Jahn, P. Bader, T. Klingebiel, K. Dietz, J. Loffler, C. Bokemeyer, C. A. Muller, and L. Kanz. 2000. Risk factors for treatment failures in patients receiving PCR-based preemptive therapy for CMV infection. Bone Marrow Transplant. 25:757-763.

67. Einsele, H., M. Steidle, A. Vallbracht, J. G. Saal, G. Ehninger, and C. A. Muller. 1991. Early occurrence of human cytomegalovirus infection after bone marrow transplantation as demonstrated by the polymerase chain reaction technique. Blood. 77:1104-1110.

68. Emery, V. C. 1999. Viral dynamics during active cytomegalovirus infection and pathology. Intervirology. 42:405-411.

69. Emery, V. C., and P. D. Griffiths. 2000. Prediction of cytomegalovirus load and resistance patterns after antiviral chemotherapy. Proc. Natl. Acad. Sci. USA. 97:8039-8044.

70. Enright, H., R. Haake, D. Weisdorf, N. Ramsay, P. McGlave, J. Kersey, W. Thomas, D. McKenzie, and W. Miller. 1993. Cytomegalovirus pneumonia after bone marrow transplantation. Risk factors and response to therapy. Transplantation. 55:1339-1346.

71. Erice, A., N. Borrell, W. Li, W. J. Miller, and H. H. Balfour, Jr. 1998. Ganciclovir susceptibilities and analysis of UL97 region in cytomegalovirus (CMV) isolates from bone marrow recipients with CMV disease after antiviral prophylaxis. J. Infect. Dis. 178:531-534.

72. Evans, P. C., A. Soin, T. G. Wreghitt, and G. J. Alexander. 1998. Qualitative and semiquantitative polymerase chain reaction testing for cytomegalovirus DNA in serum allows prediction of CMV related disease in liver transplant recipients. J. Clin. Pathol. 51:914-921.

73. Falagas, M. E., D. R. Snydman, J. Griffith, and B. G. Werner. 1996. Exposure to cytomegalovirus from the donated organ is a risk factor for bacteremia in orthotopic liver transplant recipients. Boston Center for Liver Transplantation CMVIG Study Group. Clin. Infect. Dis. 23:468-474. 
74. Falagas, M. E., D. R. Snydman, R. Ruthazer, J. Griffith, and B. G. Werner. 1996. Primary cytomegalovirus infection in liver transplant recipients: comparison of infections transmitted via donor organs and via transfusions. Boston Center for Liver Transplantation CMVIG Study Group. Clin. Infect. Dis. 23:292-297.

75. Faulds, D., and R. C. Heel. 1990. Ganciclovir. A review of its antiviral activity, pharmacokinetic properties and therapeutic efficacy in cytomegalovirus infections. Drugs. 39:597-638.

76. Fietze, E., S. Prosch, P. Reinke, J. Stein, W. D. Docke, G. Staffa, S. Loning, S. Devaux, F. Emmrich, R. von Baehr, and et al. 1994. Cytomegalovirus infection in transplant recipients. The role of tumor necrosis factor. Transplantation. 58:675-680.

77. Flye, M. W., K. Burton, T. Mohanakumar, D. Brennan, C. Keller, J. A. Goss, G. A. Sicard, and C. B. Anderson. 1995. Donor-specific transfusions have long-term beneficial effects for human renal allografts. Transplantation. 60:1395-1401.

78. Fox, J. C., I. M. Kidd, P. D. Griffiths, P. Sweny, and V. C. Emery. 1995. Longitudinal analysis of cytomegalovirus load in renal transplant recipients using a quantitative polymerase chain reaction: correlation with disease. J. Gen. Virol. 76:309-319.

79. Freise, C. E., V. Pons, J. Lake, E. Burke, N. L. Ascher, and J. P. Roberts. 1991. Comparison of three regimens for cytomegalovirus prophylaxis in 147 liver transplant recipients. Transplant. Proc. 23:1498-1500.

80. Gaeta, A., C. Nazzari, S. Angeletti, M. Lazzarini, E. Mazzei, and C. Mancini. 1997. Monitoring for cytomegalovirus infection in organ transplant recipients: analysis of pp65 antigen, DNA and late mRNA in peripheral blood leukocytes. J. Med. Virol. 53:189-195.

81. Gerna, G., F. Baldanti, D. Lilleri, M. Parea, E. Alessandrino, A. Pagani, F. Locatelli, J. Middeldorp, and M. G. Revello. 2000. Human cytomegalovirus immediate-early mRNA detection by nucleic acid sequence-based amplification as a new parameter for preemptive therapy in bone marrow transplant recipients. J. Clin. Microbiol. 38:1845-1853.

82. Gerna, G., F. Baldanti, J. Middeldorp, and D. Lilleri. 2000. Use of CMV transcripts for monitoring of CMV infections in transplant recipients. Int. J. Antimicrobial. Agents. 16:455-460.

83. Gerna, G., F. Baldanti, J. M. Middeldorp, M. Furione, M. Zavattoni, D. Lilleri, and M. G. Revello. 1999. Clinical significance of expression of human cytomegalovirus pp67 late transcript in heart, lung, and bone marrow transplant recipients as determined by nucleic acid sequencebased amplification. J. Clin. Microbiol. 37:902-911.

84. Gerna, G., M. Furione, F. Baldanti, E. Percivalle, P. Comoli, and F. Locatelli. 1995. Quantitation of human cytomegalovirus DNA in bone marrow transplant recipients. Br. J. Haematol. 91:674683.

85. Gerna, G., M. Furione, F. Baldanti, and A. Sarasini. 1994. Comparative quantitation of human cytomegalovirus DNA in blood leukocytes and plasma of transplant and AIDS patients. J. Clin. Microbiol. 32:2709-2717.

86. Gerna, G., E. Percivalle, F. Baldanti, S. Sozzani, P. Lanzarini, E. Genini, D. Lilleri, and M. G. Revello. 2000. Human cytomegalovirus replicates abortively in polymorphonuclear leukocytes after transfer from infected endothelial cells via transient microfusion events. J. Virol. 74:56295638. 
87. Gerna, G., M. G. Revello, E. Percivalle, and F. Morini. 1992. Comparison of different immunostaining techniques and monoclonal antibodies to the lower matrix phosphoprotein (pp65) for optimal quantitation of human cytomegalovirus antigenemia. J. Clin. Microbiol. 30:1232-1237.

88. Gerna, G., M. Zavattoni, F. Baldanti, A. Sarasini, L. Chezzi, P. Grossi, and M. G. Revello. 1998. Human cytomegalovirus (HCMV) leukodnaemia correlates more closely with clinical symptoms than antigenemia and viremia in heart and heart-lung transplant recipients with primary HCMV infection. Transplantation. 65:1378-1385.

89. Gerna, G., D. Zipeto, M. Parea, M. G. Revello, E. Silini, E. Percivalle, M. Zavattoni, P. Grossi, and G. Milanesi. 1991. Monitoring of human cytomegalovirus infections and ganciclovir treatment in heart transplant recipients by determination of viremia, antigenemia, and DNAemia. J. Infect. Dis. 164:488-498.

90. Gerna, G., D. Zipeto, E. Percivalle, M. Parea, M. G. Revello, R. Maccario, G. Peri, and G. Milanesi. 1992. Human cytomegalovirus infection of the major leukocyte subpopulations and evidence for initial viral replication in polymorphonuclear leukocytes from viremic patients. J. Infect. Dis. 166:1236-1244.

91. Gleaves, C. A., T. F. Smith, E. A. Shuster, and G. R. Pearson. 1985. Comparison of standard tube and shell vial cell culture techniques for the detection of cytomegalovirus in clinical specimens. J. Clin. Microbiol. 21:217-221.

92. Gold, E., and G. A. Nankervis. 1976. Cytomegalovirus, p. 143-161. In A. S. Evans (ed.), Viral infections of humans: epidemiology and control. Plenum Press, New York.

93. Gomez, E., S. Aguado, S. Melon, A. Martinez, M. de Ona, R. Cimadevilla, M. Gorostidi, E. Gonzalez, and J. Alvarez Grande. 1992. A prospective study of the usefulness of rapid diagnostic tests in monitoring cytomegalovirus infection in renal transplants. Transplant. Proc. 24:2631-2633.

94. Gomez, E., M. de Ona, S. Melon, R. Alvarez, A. Laures, M. Rodriguez, A. Pobes, and J. Alvarez Grande. 1999. Control of cytomegalovirus disease in renal transplant patients treated with prednisone, azathioprine and cyclosporine using intensive monitoring and decreased immunosuppression. Nephron. 82:238-245.

95. Gozlan, J., J. P. Laporte, S. Lesage, M. Labopin, A. Najman, N. C. Gorin, and J. C. Petit. 1996. Monitoring of cytomegalovirus infection and disease in bone marrow recipients by reverse transcription-PCR and comparison with PCR and blood and urine cultures. J. Clin. Microbiol. 34:2085-2088.

96. Gozlan, J., J. M. Salord, C. Chouaid, C. Duvivier, O. Picard, M. C. Meyohas, and J. C. Petit. 1993. Human cytomegalovirus (HCMV) late-mRNA detection in peripheral blood of AIDS patients: diagnostic value for HCMV disease compared with those of viral culture and HCMV DNA detection. J. Clin. Microbiol. 31:1943-1945.

97. Grattan, M. T., C. E. Moreno Cabral, V. A. Starnes, P. E. Oyer, E. B. Stinson, and N. E. Shumway. 1989. Cytomegalovirus infection is associated with cardiac allograft rejection and atherosclerosis. JAMA. 261:3561-3566.

98. Grefte, A., N. Blom, M. van der Giessen, W. van Son, and T. H. The. 1993. Ultrastructural analysis of circulating cytomegalic cells in patients with active cytomegalovirus infection: evidence for virus production and endothelial origin. J. Infect. Dis. 168:1110-1118. 
99. Grefte, A., M. C. Harmsen, M. van der Giessen, S. Knollema, W. J. van Son, and T. H. The. 1994. Presence of human cytomegalovirus (HCMV) immediate early mRNA but not ppUL83 (lower matrix protein pp65) mRNA in polymorphonuclear and mononuclear leukocytes during active HCMV infection. J. Gen. Virol. 75:1989-1998.

100. Grefte, A., M. van der Giessen, W. van Son, and T. H. The. 1993. Circulating cytomegalovirus (CMV)-infected endothelial cells in patients with an active CMV infection. J. Infect. Dis. 167:270277.

101. Grefte, J. M., B. T. van der Gun, S. Schmolke, M. van der Giessen, W. J. van Son, B. Plachter, G. Jahn, and T. H. The. 1992. The lower matrix protein pp65 is the principal viral antigen present in peripheral blood leukocytes during an active cytomegalovirus infection. J. Gen. Virol. 73:29232932.

102. Greijer, A. E., H. M. Adriaanse, M. Kahl, N. M. Tacken, N. Oldenburg, A. Sijlmans, J. M. van de Crommert, C. A. Dekkers, P. T. Sillekens, and J. M. Middeldorp. 2001. Quantitative competitive NASBA for measuring mRNA expression levels of the immediate early 1, late pp67, and immune evasion genes US3, US6 and US11 in cells infected with human cytomegalovirus. J. Virol. Methods. 96:133-147.

103. Greijer, A. E., E. A. Verschuuren, C. A. Dekkers, H. M. Adriaanse, W. van Der Bij, T. H. The, and J. M. Middeldorp. 2001. Expression dynamics of human cytomegalovirus immune evasion genes US3, US6, and US11 in the blood of lung transplant recipients. J. Infect. Dis. 184:247-255.

104. Greijer, A. E., E. A. Verschuuren, M. C. Harmsen, C. A. Dekkers, H. M. Adriaanse, T. H. The, and J. M. Middeldorp. 2001. Direct quantification of human cytomegalovirus immediate-early and late mRNA levels in blood of lung transplant recipients by competitive nucleic acid sequence-based amplification. J. Clin. Microbiol. 39:251-259.

105. Griffiths, P. D., and J. E. Grundy. 1988. The status of CMV as a human pathogen. Epidemiol. Infect. 100:1-15.

106. Grossi, P., S. Kusne, C. Rinaldo, K. St George, M. Magnone, J. Rakela, J. Fung, and T. E. Starzl. 1996. Guidance of ganciclovir therapy with pp65 antigenemia in cytomegalovirus-free recipients of livers from seropositive donors. Transplantation. 61:1659-1660.

107. Grossi, P., L. Minoli, E. Percivalle, W. Irish, M. Vigano, and G. Gerna. 1995. Clinical and virological monitoring of human cytomegalovirus infection in 294 heart transplant recipients. Transplantation. 59:847-851.

108. Grundy, J. E., S. F. Lui, M. Super, N. J. Berry, P. Sweny, O. N. Fernando, J. Moorhead, and P. D. Griffiths. 1988. Symptomatic cytomegalovirus infection in seropositive kidney recipients: reinfection with donor virus rather than reactivation of recipient virus. Lancet. 2:132-135.

109. Gulizia, J. M., R. Kandolf, T. J. Kendall, S. L. Thieszen, J. E. Wilson, S. J. Radio, M. R. Costanzo, G. L. Winters, L. L. Miller, and B. M. McManus. 1995. Infrequency of cytomegalovirus genome in coronary arteriopathy of human heart allografts. Am. J. Pathol. 147:461-475.

110. Hahn, G., R. Jores, and E. S. Mocarski. 1998. Cytomegalovirus remains latent in a common precursor of dendritic and myeloid cells. Proc. Natl. Acad. Sci. USA. 95:3937-3942.

111. Hamilton, J. D., and B. J. Seaworth. 1985. Transmission of latent cytomegalovirus in a murine kidney tissue transplantation model. Transplantation. 39:290-296. 
112. Hassan-Walker, A. F., A. V. Cope, P. D. Griffiths, and V. C. Emery. 1998. Transcription of the human cytomegalovirus natural killer decoy gene, UL18, in vitro and in vivo. J. Gen. Virol. 79:2113-2116.

113. Hassan-Walker, A. F., F. M. Mattes, P. D. Griffiths, and V. C. Emery. 2001. Quantity of cytomegalovirus DNA in different leukocyte populations during active infection in vivo and the presence of gB and UL18 transcripts. J. Med. Virol. 64:283-289.

114. Hendrix, M. G., E. Beuken, R. L. Slobbe, and C. A. Bruggeman. 1996. Detection and sequence analysis of the major immediate early and PP150 gene of latent human cytomegalovirus in spleen, liver, and kidney tissues of trauma victims. J. Med. Virol. 50:193-197.

115. Hendrix, M. G., M. Daemen, and C. A. Bruggeman. 1991. Cytomegalovirus nucleic acid distribution within the human vascular tree. Am. J. Pathol. 138:563-567.

116. Henry, S. C., and J. D. Hamilton. 1993. Detection of murine cytomegalovirus immediate early 1 transcripts in the spleens of latently infected mice. J. Infect. Dis. 167:950-954.

117. Hibberd, P. L., N. E. Tolkoff Rubin, D. Conti, F. Stuart, J. R. Thistlethwaite, J. F. Neylan, D. R. Snydman, R. Freeman, M. I. Lorber, and R. H. Rubin. 1995. Preemptive ganciclovir therapy to prevent cytomegalovirus disease in cytomegalovirus antibody-positive renal transplant recipients. A randomized controlled trial. Ann. Intern. Med. 123:18-26.

118. Hirata, M., P. I. Terasaki, and Y. W. Cho. 1996. Cytomegalovirus antibody status and renal transplantation: 1987-1994. Transplantation. 62:34-37.

119. Hiyoshi, M., S. Tagawa, T. Takubo, K. Tanaka, T. Nakao, Y. Higeno, K. Tamura, M. Shimaoka, A. Fujii, M. Higashihata, Y. Yasui, T. Kim, A. Hiraoka, and N. Tatsumi. 1997. Evaluation of the AMPLICOR CMV test for direct detection of cytomegalovirus in plasma specimens. J. Clin. Microbiol. 35:2692-2694.

120. Ho, M. 1994. Advances in understanding cytomegalovirus infection after transplantation. Transplant Proc. 26:7-11.

121. Ho, M. 1990. Epidemiology of cytomegalovirus infections. Rev. Infect. Dis. 12 Suppl. 7:S701-710.

122. Horn, T. D., E. R. Farmer, G. B. Vogelsang, J. R. Wingard, and G. W. Santos. 1989. Cutaneous graft-versus-host reaction lacks evidence of cutaneous cytomegalovirus by the immunoperoxidase technique. J. Invest. Dermatol. 93:92-95.

123. Humar, A., D. Gregson, A. M. Caliendo, A. McGeer, G. Malkan, M. Krajden, P. Corey, P. Greig, S. Walmsley, G. Levy, and T. Mazzulli. 1999. Clinical utility of quantitative cytomegalovirus viral load determination for predicting cytomegalovirus disease in liver transplant recipients. Transplantation. 68:1305-1311.

124. Ibanez, C. E., R. Schrier, P. Ghazal, C. Wiley, and J. A. Nelson. 1991. Human cytomegalovirus productively infects primary differentiated macrophages. J. Virol. 65:6581-6588.

125. Jahn, G., T. Kouzarides, M. Mach, B. C. Scholl, B. Plachter, B. Traupe, E. Preddie, S. C. Satchwell, B. Fleckenstein, and B. G. Barrell. 1987. Map position and nucleotide sequence of the gene for the large structural phosphoprotein of human cytomegalovirus. J. Virol. 61:1358-1367.

126. Jamil, B., K. M. Nicholls, G. J. Becker, and R. G. Walker. 2000. Influence of anti-rejection therapy on the timing of cytomegalovirus disease and other infections in renal transplant recipients. Clin. Transplant. 14:14-18. 
127. Jonjic, S., I. Pavic, B. Polic, I. Crnkovic, P. Lucin, and U. H. Koszinowski. 1994. Antibodies are not essential for the resolution of primary cytomegalovirus infection but limit dissemination of recurrent virus. J. Exp. Med. 179:1713-1717.

128. Jordan, M. C. 1980. Adverse effects of cytomegalovirus vaccination in mice. J. Clin. Invest. 65:798-803.

129. Jordan, M. C., and V. L. Mar. 1982. Spontaneous activation of latent cytomegalovirus from murine spleen explants. Role of lymphocytes and macrophages in release and replication of virus. J. Clin. Invest. 70:762-768.

130. Kloover, J. S., A. P. Soots, L. A. Krogerus, H. O. Kauppinen, R. J. Loginov, K. L. Holma, C. A. Bruggeman, P. J. Ahonen, and I. T. Lautenschlager. 2000. Rat cytomegalovirus infection in kidney allograft recipients is associated with increased expression of intracellular adhesion molecule-1 vascular adhesion molecule-1, and their ligands leukocyte function antigen-1 and very late antigen-4 in the graft. Transplantation. 69:2641-2647.

131. Klotman, M. E., S. C. Henry, R. C. Greene, P. C. Brazy, P. E. Klotman, and J. D. Hamilton. 1990. Detection of mouse cytomegalovirus nucleic acid in latently infected mice by in vitro enzymatic amplification. J. Infect. Dis. 161:220-225.

132. Koffron, A. J., M. Hummel, B. K. Patterson, S. Yan, D. B. Kaufman, J. P. Fryer, F. P. Stuart, and M. I. Abecassis. 1998. Cellular localization of latent murine cytomegalovirus. J. Virol. 72:95-103.

133. Kondo, K., H. Kaneshima, and E. S. Mocarski. 1994. Human cytomegalovirus latent infection of granulocyte-macrophage progenitors. Proc. Natl. Acad. Sci. USA. 91:11879-11883.

134. Kondo, K., J. Xu, and E. S. Mocarski. 1996. Human cytomegalovirus latent gene expression in granulocyte-macrophage progenitors in culture and in seropositive individuals. Proc. Natl. Acad. Sci. USA. 93:11137-11142.

135. Krajden, M., P. Shankaran, C. Bourke, and W. Lau. 1996. Detection of cytomegalovirus in blood donors by PCR using the digene SHARP signal system assay: effects of sample preparation and detection methodology. J. Clin. Microbiol. 34:29-33.

136. Krech, U., M. Jung, and F. Jung. 1971. Cytomegalovirus infections in man. S. Karger AG, New York.

137. Kroshus, T. J., V. R. Kshettry, K. Savik, R. John, M. I. Hertz, and R. M. Bolman. 1997. Risk factors for the development of bronchiolitis obliterans syndrome after lung transplantation. J. Thorac. Cardiovasc. Surg. 114:195-202.

138. Kruger, R. M., W. D. Shannon, M. Q. Arens, J. P. Lynch, G. A. Storch, and E. P. Trulock. 1999. The impact of ganciclovir-resistant cytomegalovirus infection after lung transplantation. Transplantation. 68:1272-1279.

139. Kurz, S., H. P. Steffens, A. Mayer, J. R. Harris, and M. J. Reddehase. 1997. Latency versus persistence or intermittent recurrences: evidence for a latent state of murine cytomegalovirus in the lungs. J. Virol. 71:2980-2987.

140. Kurz, S. K., M. Rapp, H. P. Steffens, N. K. Grzimek, S. Schmalz, and M. J. Reddehase. 1999. Focal transcriptional activity of murine cytomegalovirus during latency in the lungs. J. Virol. 73:482-494.

141. Kurz, S. K., and M. J. Reddehase. 1999. Patchwork pattern of transcriptional reactivation in the lungs indicates sequential checkpoints in the transition from murine cytomegalovirus latency to recurrence. J. Virol. 73:8612-8622. 
142. Kusne, S., P. Grossi, W. Irish, K. St. George, C. Rinaldo, J. Rakela, and J. Fung. 1999. Cytomegalovirus PP65 antigenemia monitoring as a guide for preemptive therapy: a cost effective strategy for prevention of cytomegalovirus disease in adult liver transplant recipients. Transplantation. 68:1125-1131.

143. Lam, K. M., N. Oldenburg, M. A. Khan, V. Gaylore, G. W. Mikhail, P. D. Strouhal, J. M. Middeldorp, N. Banner, and M. Yacoub. 1998. Significance of reverse transcription polymerase chain reaction in the detection of human cytomegalovirus gene transcripts in thoracic organ transplant recipients. J. Heart Lung Transplant. 17:555-565.

144. Landini, M. P. 1993. New approaches and perspectives in cytomegalovirus diagnosis. Prog. Med. Virol. 40:157-177.

145. Landini, M. P., T. Lazzarotto, J. Xu, A. P. Geballe, and E. S. Mocarski. 2000. Humoral immune response to proteins of human cytomegalovirus latency-associated transcripts. Biol. Blood Marrow Transplant. 6:100-108.

146. Landry, M. L., and D. Ferguson. 1993. Comparison of quantitative cytomegalovirus antigenemia assay with culture methods and correlation with clinical disease. J. Clin. Microbiol. 31:2851-2856.

147. Lang, D. J., P. A. Ebert, B. M. Rodgers, H. P. Boggess, and R. S. Rixse. 1977. Reduction of postperfusion cytomegalovirus-infections following the use of leukocyte depleted blood. Transfusion. 17:391-395.

148. Larsson, S., C. Söderberg-Nauclér, and E. Moller. 1998. Productive cytomegalovirus (CMV) infection exclusively in CD13-positive peripheral blood mononuclear cells from CMV-infected individuals: implications for prevention of CMV transmission. Transplantation. 65:411-415.

149. Laske, A., A. Gallino, P. Mohacsi, E. P. Bauer, T. Carrel, L. K. von Segesser, and M. I. Turina. 1991. Prophylactic treatment with ganciclovir for cytomegalovirus infection in heart transplantation. Transplant. Proc. 23:1170-1173.

150. Lassner, D., F. Geissler, S. Bosse, J. Hofmann, H. Witzigmann, H. Remke, J. Hauss, and O. Wagner. 2000. Diagnosis and monitoring of acute cytomegalovirus infection in peripheral blood of transplant recipients by nested reverse transcriptase polymerase chain reaction (RT-PCR). Transpl. Int. 13:S366-371.

151. Lathey, J. L., and S. A. Spector. 1991. Unrestricted replication of human cytomegalovirus in hydrocortisone-treated macrophages. J. Virol. 65:6371-6375.

152. Lautenschlager, I., A. Soots, L. Krogerus, H. Kauppinen, O. Saarinen, C. Bruggeman, and J. Ahonen. 1997. Effect of cytomegalovirus on an experimental model of chronic renal allograft rejection under triple-drug treatment in the rat. Transplantation. 64:391-398.

153. Lewis, R. M., P. C. Johnson, D. Golden, C. T. Van Buren, R. H. Kerman, and B. D. Kahan. 1988. The adverse impact of cytomegalovirus infection on clinical outcome in cyclosporine-prednisone treated renal allograft recipients. Transplantation. 45:353-359.

154. Li, W., F. Anwar, J. Jesurrun, and A. Erice. 1999. Cytomegalovirus UL97 and glycoprotein B (gB) sequences in tissues from immunocompromised patients with ganciclovir-resistant virus infection. Scand. J. Infect. Dis. 31:549-553.

155. Ljungman, P., J. Aschan, I. Lewensohn Fuchs, S. Carlens, K. Larsson, B. Lonnqvist, J. Mattsson, E. Sparrelid, J. Winiarski, and O. Ringden. 1998. Results of different strategies for reducing cytomegalovirus-associated mortality in allogeneic stem cell transplant recipients. Transplantation. 66:1330-1334. 
156. Ljungman, P., D. Niederwieser, M. S. Pepe, G. Longton, R. Storb, and J. D. Meyers. 1990. Cytomegalovirus infection after marrow transplantation for aplastic anemia. Bone Marrow Transplant. 6:295-300.

157. Loenen, W. A. M., C. A. Bruggeman, and E. J. H. J. Wiertz. 2001. Immune evasion by human cytomegalovirus: lessons in immunology and cell biology. Semin. Immunol. 13:41-49.

158. Lumbreras, C., J. R. Otero, J. A. Herrero, R. Gomez, M. Lizasoain, J. M. Aguado, F. Colina, I. Garcia, E. Moreno, and A. R. Noriega. 1993. Ganciclovir prophylaxis decreases frequency and severity of cytomegalovirus disease in seropositive liver transplant recipients treated with OKT3 monocional antibodies. Antimicrob. Agents Chemother. 37:2490-2492.

159. Lunetta, J. M., and J. A. Wiedeman. 2000. Latency-associated sense transcripts are expressed during in vitro human cytomegalovirus productive infection. Virology. 278:467-476.

160. Machida, U., M. Kami, T. Fukui, Y. Kazuyama, M. Kinoshita, Y. Tanaka, Y. Kanda, S. Ogawa, H. Honda, S. Chiba, K. Mitani, Y. Muto, K. Osumi, S. Kimura, and H. Hirai. 2000. Real-time automated PCR for early diagnosis and monitoring of cytomegalovirus infection after bone marrow transplantation. J. Clin. Microbiol. 38:2536-2542.

161. Maciejewski, J. P., E. E. Bruening, R. E. Donahue, E. S. Mocarski, N. S. Young, and S. C. St Jeor. 1992. Infection of hematopoietic progenitor cells by human cytomegalovirus. Blood. 80:170-178.

162. Manez, R., S. Kusne, C. Rinaldo, J. M. Aguado, K. St George, P. Grossi, B. Frye, J. J. Fung, and G. D. Ehrlich. 1996. Time to detection of cytomegalovirus (CMV) DNA in blood leukocytes is a predictor for the development of CMV disease in CMV-seronegative recipients of allografts from CMV-seropositive donors following liver transplantation. J. Infect. Dis. 173:1072-1076.

163. Manning, W. C., C. A. Stoddart, L. A. Lagenaur, G. B. Abenes, and E. S. Mocarski. 1992. Cytomegalovirus determinant of replication in salivary glands. J. Virol. 66:3794-3802.

164. Marsano, L., R. P. Perrillo, M. W. Flye, D. W. Hanto, E. D. Spitzer, J. R. Thomas, P. R. Murray, D. W. Windus, E. M. Brunt, and G. A. Storch. 1990. Comparison of culture and serology for the diagnosis of cytomegalovirus infection in kidney and liver transplant recipients. J. Infect. Dis. 161:454-461.

165. Martelius, T., L. Krogerus, K. Hockerstedt, C. Bruggeman, and I. Lautenschlager. 1998. Cytomegalovirus infection is associated with increased inflammation and severe bile duct damage in rat liver allografts. Hepatology. 27:996-1002.

166. Martin, M., R. Manez, P. Linden, D. Estores, J. Torre Cisneros, S. Kusne, L. Ondick, R. Ptachcinski, W. Irish, D. Kisor, and et. al. 1994. A prospective randomized trial comparing sequential ganciclovir-high dose acyclovir to high dose acyclovir for prevention of cytomegalovirus disease in adult liver transplant recipients. Transplantation. 58:779-785.

167. Mathew, T. H. 1998. A blinded, long-term, randomized multicenter study of mycophenolate mofetil in cadaveric renal transplantation: results at three years. Tricontinental Mycophenolate Mofetil Renal Transplantation Study Group. Transplantation. 65:1450-1454.

168. Mayo, D., J. A. Armstrong, and M. Ho. 1978. Activation of latent murine cytomegalovirus infection: cocultivation, cell transfer, and the effect of immunosuppression. J. Infect. Dis. 138:890896.

169. Melnick, J. L., C. Hu, J. Burek, E. Adam, and M. E. DeBakey. 1994. Cytomegalovirus DNA in arterial walls of patients with atherosclerosis. J. Med. Virol. 42:170-174. 
170. Mendelson, M., S. Monard, P. Sissons, and J. Sinclair. 1996. Detection of endogenous human cytomegalovirus in CD34+ bone marrow progenitors. J. Gen. Virol. 77:3099-3102.

171. Mendez, J., M. Espy, T. F. Smith, J. Wilson, R. Wiesner, and C. V. Paya. 1998. Clinical significance of viral load in the diagnosis of cytomegalovirus disease after liver transplantation. Transplantation. 65:1477-1481.

172. Mercer, J. A., C. A. Wiley, and D. H. Spector. 1988. Pathogenesis of murine cytomegalovirus infection: identification of infected cells in the spleen during acute and latent infections. J. Virol. 62:987-997.

173. Merigan, T. C., D. G. Renlund, S. Keay, M. R. Bristow, V. Starnes, J. B. O'Connell, S. Resta, D. Dunn, P. Gamberg, R. M. Ratkovec, and et al. 1992. A controlled trial of ganciclovir to prevent cytomegalovirus disease after heart transplantation. N. Engl. J. Med. 326:1182-1186.

174. Meyer, T., U. Reischl, H. Wolf, C. Schuller, and R. Arndt. 1994. Identification of active cytomegalovirus infection by analysis of immediate-early, early and late transcripts in peripheral blood cells of immunodeficient patients. Mol. Cell. Probes. 8:261-271.

175. Meyer-Konig, U., F. T. Hufert, and D. M. von Laer. 1997. Infection of blood and bone marrow cells with the human cytomegalovirus in vivo. Leuk. Lymphoma. 25:445-454.

176. Meyer-Koning, U., A. Serr, D. von Laer, G. Kirste, C. Wolff, O. Haller, D. Neumann Haefelin, and E. T. Hufert. 1995. Human cytomegalovirus immediate early and late transcripts in peripheral blood leukocytes: diagnostic value in renal transplant recipients. J. Infect. Dis. 171:705-709.

177. Meyers, J. D., N. Flournoy, and E. D. Thomas. 1982. Nonbacterial pneumonia after allogeneic marrow transplantation: a review of ten years' experience. Rev. Infect. Dis. 4:1119-1132.

178. Meyers, J. D., N. Flournoy, and E. D. Thomas. 1986. Risk factors for cytomegalovirus infection after human marrow transplantation. J. Infect. Dis. 153:478-488.

179. Meyers, J. D., P. Ljungman, and L. D. Fisher. 1990. Cytomegalovirus excretion as a predictor of cytomegalovirus disease after marrow transplantation: importance of cytomegalovirus viremia. J. Infect. Dis. 162:373-380.

180. Middeldorp, J. M., P. Sillekens, and J. Lunenberg. 2000. Diagnosis of active HCMV infection: the mRNA approach. Organs Tissues. 2:99-107.

181. Mims, C. A., and J. Gould. 1978. The role of macrophages in mice infected with murine cytomegalovirus. J. Gen. Virol. 41:143-153.

182. Minton, E. J., C. Tysoe, J. H. Sinclair, and J. G. Sissons. 1994. Human cytomegalovirus infection of the monocyte/macrophage lineage in bone marrow. J. Virol. 68:4017-4021.

183. Mocarski, E. S. 1996. Cytomegaloviruses and their replication, p. 2447-2492. In B. N. Fields and D. M. Knipe and P. M. Howley (ed.), Fields Virology, 3th ed, vol. 2. Lippincott - Raven Publishers, Philadelphia.

184. Monte, P. D., T. Lazzarotto, A. Ripalti, and M. P. Landini. 1996. Human cytomegalovirus infection: a complex diagnostic problem in which molecular biology has induced a rapid evolution. Intervirology. 39:193-203.

185. Mori, T., S. Okamoto, S. Matsuoka, T. Yajima, M. Wakui, R. Watanabe, A. Ishida, Y. Iwao, M. Mukai, T. Hibi, and Y. Ikeda. 2000. Risk-adapted pre-emptive therapy for cytomegalovirus disease in patients undergoing allogeneic bone marrow transplantation. Bone Marrow Transplantation. 25:765-769. 
186. Muller, C. A., H. Hebart, A. Roos, H. Roos, M. Steidle, and H. Einsele. 1995. Correlation of interstitial pneumonia with human cytomegalovirus-induced lung infection and graft-versushost disease after bone marrow transplantation. Med. Microbiol. Immunol. Berl. 184:115-121.

187. Mutimer, D., A. Matyi Toth, J. Shaw, E. Elias, K. O'Donnell, and P. Stalhandske. 1997. Patterns of viremia in liver transplant recipients with symptomatic cytomegalovirus infection. Transplantation. 63:68-73.

188. Mutimer, D., D. Mirza, J. Shaw, K. O'Donnell, and E. Elias. 1997. Enhanced (cytomegalovirus) viral replication associated with septic bacterial complications in liver transplant recipients. Transplantation. 63:1411-1415.

189. Nakazato, P. Z., W. Burns, P. Moore, R. Garcia Kennedy, K. Cox, and C. Esquivel. 1993. Viral prophylaxis in hepatic transplantation: preliminary report of a randomized trial of acyclovir and gancyclovir. Transplant. Proc. 25:1935-1937.

190. Nelson, P. N., B. K. Rawal, Y. S. Boriskin, K. E. Mathers, R. L. Powles, H. M. Steel, Y. S. Tryhorn, P. D. Butcher, and J. C. Booth. 1996. A polymerase chain reaction to detect a spliced late transcript of human cytomegalovirus in the blood of bone marrow transplant recipients. J. Virol. Methods. 56:139-148.

191. Nitsche, A., N. Steuer, C. A. Schmidt, O. Landt, H. Ellerbrok, G. Pauli, and W. Siegert. 2000. Detection of human cytomegalovirus DNA by real-time quantitative PCR. J. Clin. Microbiol. 38:2734-2737

192. Nitsche, A., N. Steuer, C. A. Schmidt, O. Landt, and W. Siegert. 1999. Different real-time PCR formats compared for the quantitative detection of human cytomegalovirus DNA. Clin. Chem. 45:1932-1937.

193. O'Grady, J. G., G. J. Alexander, S. Sutherland, P. T. Donaldson, F. Harvey, B. Portmann, R. Y. Calne, and R. Williams. 1988. Cytomegalovirus infection and donor/recipient HLA antigens: interdependent co-factors in pathogenesis of vanishing bile-duct syndrome after liver transplantation. Lancet. 2:302-305.

194. Oldenburg, N., K. M. Lam, M. A. Khan, B. Top, N. M. Tacken, A. McKie, G. W. Mikhail, J. M. Middeldorp, A. Wright, N. R. Banner, and M. Yacoub. 2000. Evaluation of human cytomegalovirus gene expression in thoracic organ transplant recipients using nucleic acid sequence-based amplification. Transplantation. 70:1209-1215.

195. Panjwani, D. D., M. G. Ball, N. J. Berry, J. Z. Wimperis, H. A. Blacklock, H. G. Prentice, A. V. Hoffbrand, and P. D. Griffiths. 1985. Virological and serological diagnosis of cytomegalovirus infection in bone marrow allograft recipients. J. Med. Virol. 16:357-365.

196. Pass, R. F., W. K. Long, R. J. Whitley, S. J. Soong, A. G. Diethelm, D. W. Reynolds, and C. A. Alford, Jr. 1978. Productive infection with cytomegalovirus and herpes simplex virus in renal transplant recipients: role of source of kidney. J. Infect. Dis. 137:556-563.

197. Pass, R. F., R. J. Whitley, A. G. Diethelm, J. D. Whelchel, D. W. Reynolds, and C. A. Alford. 1980. Cytomegalovirus infection in patients with renal transplants: potentiation by antithymocyte globulin and an incompatible graft. J. Infect. Dis. 142:9-17.

198. Patel, R., D. W. Klein, M. J. Espy, W. S. Harmsen, D. M. Ilstrup, C. V. Paya, and T. F. Smith. 1995. Optimization of detection of cytomegalovirus viremia in transplantation recipients by shell vial assay. J. Clin. Microbiol. 33:2984-2986. 
199. Patel, R., and C. V. Paya. 1997. Infections in solid-organ transplant recipients. Clin. Microbiol. Rev. 10:86-124.

200. Patel, R., T. F. Smith, M. Espy, D. Portela, R. H. Wiesner, R. A. Krom, and C. V. Paya. 1995. A prospective comparison of molecular diagnostic techniques for the early detection of cytomegalovirus in liver transplant recipients. J. Infect. Dis. 171:1010-1014.

201. Patel, R., T. F. Smith, M. Espy, R. H. Wiesner, R. A. Krom, D. Portela, and C. V. Paya. 1994. Detection of cytomegalovirus DNA in sera of liver transplant recipients. J. Clin. Microbiol. 32:1431-1434.

202. Paya, C. V., T. F. Smith, J. Ludwig, and P. E. Hermans. 1989. Rapid shell vial culture and tissue histology compared with serology for the rapid diagnosis of cytomegalovirus infection in liver transplantation. Mayo Clin. Proc. 64:670-675.

203. Paya, C. V., R. H. Wiesner, P. E. Hermans, J. J. Larson Keller, D. M. Ilstrup, R. A. Krom, S. Rettke, and T. F. Smith. 1993. Risk factors for cytomegalovirus and severe bacterial infections following liver transplantation: a prospective multivariate time-dependent analysis. J. Hepatol. 18:185-195.

204. Pellegrin, I., I. Garrigue, D. Ekouevi, L. Couzi, P. Merville, P. Merel, G. Chene, M. H. Schrive, P. Trimoulet, M. E. Lafon, and H. Fleury. 2000. New molecular assays to predict occurrence of cytomegalovirus disease in renal transplant recipients. J. Infect. Dis. 182:36-42.

205. Percivalle, E., M. G. Revello, L. Vago, F. Morini, and G. Gerna. 1993. Circulating endothelial giant cells permissive for human cytomegalovirus (HCMV) are detected in disseminated HCMV infections with organ involvement. J. Clin. Invest. 92:663-670.

206. Pollock, J. L., R. M. Presti, S. Paetzold, and H. W. Virgin. 1997. Latent murine cytomegalovirus infection in macrophages. Virology. 227:168-179.

207. Pollock, J. L., and H. W.t. Virgin. 1995. Latency, without persistence, of murine cytomegalovirus in the spleen and kidney. J. Virol. 69:1762-1768.

208. Pomeroy, C., P. J. Hilleren, and M. C. Jordan. 1991. Latent murine cytomegalovirus DNA in splenic stromal cells of mice. J.Virol. 65:3330-3334.

209. Portela, D., R. Patel, J. J. Larson Keller, D. M. Ilstrup, R. H. Wiesner, J. L. Steers, R. A. Krom, and C. V. Paya. 1995. OKT3 treatment for allograft rejection is a risk factor for cytomegalovirus disease in liver transplantation. J. Infect. Dis. 171:1014-1018.

210. Priscott, P. K., and D. A. Tyrrell. 1982. The isolation and partial characterisation of a cytomegalovirus from the brown rat, Rattus norvegicus. Arch. Virol. 73:145-160.

211. Randhawa, P. S., R. Manez, B. Frye, and G. D. Ehrlich. 1994. Circulating immediate-early mRNA in patients with cytomegalovirus infections after solid organ transplantation. J. Infect. Dis. 170:1264-1267.

212. Rawlinson, W. D., and B. G. Barrell. 1993. Spliced transcripts of human cytomegalovirus. J. Virol. 67:5502-5513.

213. Reusser, P., L. D. Fisher, C. D. Buckner, E. D. Thomas, and J. D. Meyers. 1990. Cytomegalovirus infection after autologous bone marrow transplantation: occurrence of cytomegalovirus disease and effect on engraftment. Blood. 75:1888-1894.

214. Rice, G. P., R. D. Schrier, and M. B. Oldstone. 1984. Cytomegalovirus infects human lymphocytes and monocytes: virus expression is restricted to immediate-early gene products. Proc. Natl. Acad. Sci. USA. 81:6134-6138. 
215. Rice, P. S., G. Kudesia, C. Price, and G. H. Smith. 1992. Diagnosis of cytomegalovirus infection in heart transplant recipients. J. Clin. Pathol. 45:636-637.

216. Roberts, T. C., D. C. Brennan, R. S. Buller, M. Gaudreault Keener, M. A. Schnitzler, K. E. Sternhell, K. A. Garlock, G. G. Singer, and G. A. Storch. 1998. Quantitative polymerase chain reaction to predict occurrence of symptomatic cytomegalovirus infection and assess response to ganciclovir therapy in renal transplant recipients. J. Infect. Dis. 178:626-635.

217. Rosen, H. R., K. G. Benner, K. D. Flora, J. M. Rabkin, S. L. Orloff, A. Olyaei, and S. Chou. 1997. Development of ganciclovir resistance during treatment of primary cytomegalovirus infection after liver transplantation. Transplantation. 65:1476-478.

218. Ross, D. J., P. F. Waters, M. Levine, M. Kramer, S. Ruzevich, and R. M. Kass. 1998. Mycophenolate mofetil versus azathioprine immunosuppressive regimens after lung transplantation: preliminary experience. J. Heart Lung Transplant. 17:768-774.

219. Rubie, H., M. Attal, A. M. Campardou, C. Gayet Mengelle, C. Payen, F. Sanguignol, J. P. Calot, J. P. Charlet, A. Robert, F. Huguet, and et. al. 1993. Risk factors for cytomegalovirus infection in BMT recipients transfused exclusively with seronegative blood products. Bone Marrow Transplant. 11:209-214.

220. Rubin, R. H. 1990. Impact of cytomegalovirus infection on organ transplant recipients. Rev. Infect. Dis. 12 Suppl. 7:S754-S766.

221. Rubin, R. H. 1991. Preemptive therapy in immunocompromised hosts. N. Engl. J. Med. 324:10571059.

222. Rubin, R. H., N. E. Tolkoff Rubin, D. Oliver, T. R. Rota, J. Hamilton, R. F. Betts, R. F. Pass, W. Hillis, W. Szmuness, M. L. Farrell, and et. al. 1985. Multicenter seroepidemiologic study of the impact of cytomegalovirus infection on renal transplantation. Transplantation. 40:243-249.

223. Rubin, R. H., E. J. Wilson, L. V. Barrett, and D. N. Medearis. 1984. Primary cytomegalovirus infection following cardiac transplantation in a murine model. Transplantation. 37:306-310.

224. Saltzman, R. L., M. R. Quirk, and M. C. Jordan. 1988. Disseminated cytomegalovirus infection. Molecular analysis of virus and leukocyte interactions in viremia. J. Clin. Invest. 81:75-81.

225. Saltzman, R. L., M. R. Quirk, and M. C. Jordan. 1992. High levels of circulating cytomegalovirus DNA reflect visceral organ disease in viremic immunosuppressed patients other than marrow recipients. J. Clin. Invest. 90:1832-1838.

226. Sandford, G. R., and W. H. Burns. 1996. Rat cytomegalovirus has a unique immediate early gene enhancer. Virology. 222:310-317.

227. Sandford, G. R., K. Ho, and W. H. Burns. 1993. Characterization of the major locus of immediate-early genes of rat cytomegalovirus. J. Virol. 67:4093-4103.

228. Sarmiento, J. M., S. R. Munn, C. V. Paya, J. A. Velosa, and J. H. Nguyen. 1998. Is cytomegalovirus infection related to mycophenolate mofetil after kidney transplantation? A case-control study. Clin. Transplant. 12:371-374.

229. Schafer, P., W. Tenschert, K. Gutensohn, and R. Laufs. 1997. Minimal effect of delayed sample processing on results of quantitative PCR for cytomegalovirus DNA in leukocytes compared to results of an antigenemia assay. J. Clin. Microbiol. 35:741-744.

230. Schmader, K., S. C. Henry, R. J. Rahija, Y. Yu, G. G. Daley, and J. D. Hamilton. 1995. Mouse cytomegalovirus reactivation in severe combined immune deficient mice after implantation of latently infected salivary gland. J. Infect. Dis. 172:531-534. 
231. Schmader, K. E., R. J. Rahija, K. R. Porter, and J. D. Hamilton. 1991. Murine cytomegalovirus gene amplification and culture after submaxillary salivary gland biopsy. Lab. Anim. Sci. 41:396400.

232. Schrier, R. D., J. A. Nelson, and M. B. Oldstone. 1985. Detection of human cytomegalovirus in peripheral blood lymphocytes in a natural infection. Science. 230:1048-1051.

233. Sia, I. G., and R. Patel. 2000. New strategies for prevention and therapy of cytomegalovirus infection and disease in solid-organ transplant recipients. Clin. Microbiol. Rev. 13:83-121.

234. Simpson, J. A., J. C. Chow, J. Baker, N. Avdalovic, S. Yuan, D. Au, M. S. Co, M. Vasquez, W. J. Britt, and K. L. Coelingh. 1993. Neutralizing monoclonal antibodies that distinguish three antigenic sites on human cytomegalovirus glycoprotein $\mathrm{H}$ have conformationally distinct binding sites. J. Virol. 67:489-496.

235. Singh, N., J. S. Dummer, S. Kusne, M. K. Breinig, J. A. Armstrong, L. Makowka, T. E. Starzl, and M. Ho. 1988. Infections with cytomegalovirus and other herpesviruses in 121 liver transplant recipients: transmission by donated organ and the effect of OKT3 antibodies. J. Infect. Dis. 158:124-131.

236. Slobedman, B., and E. S. Mocarski. 1999. Quantitative analysis of latent human cytomegalovirus. J. Virol. 73:4806-48112.

237. Smiley, M. L., C. G. Wlodaver, R. A. Grossman, C. F. Barker, L. J. Perloff, N. B. Tustin, S. E. Starr, S. A. Plotkin, and H. M. Friedman. 1985. The role of pretransplant immunity in protection from cytomegalovirus disease following renal transplantation. Transplantation. 40:157-161.

238. Smith, T. F., and C. D. Shelley. 1988. Detection of IgM antibody to cytomegalovirus and rapid diagnosis of this virus infection by the shell vial assay. J. Virol. Methods. 21:87-96.

239. Smyth, R. L., J. P. Scott, L. K. Borysiewicz, L. D. Sharples, S. Stewart, T. G. Wreghitt, J. J. Gray, T. W. Higenbottam, and J. Wallwork. 1991. Cytomegalovirus infection in heart-lung transplant recipients: risk factors, clinical associations, and response to treatment. J. Infect. Dis. 164:10451050 .

240. Söderberg, C., S. Larsson, S. Bergstedt Lindqvist, and E. Moller. 1993. Definition of a subset of human peripheral blood mononuclear cells that are permissive to human cytomegalovirus infection. J. Virol. 67:3166-3175.

241. Söderberg-Nauclér, C., K. N. Fish, and J. A. Nelson. 1997. Reactivation of latent human cytomegalovirus by allogeneic stimulation of blood cells from healthy donors. Cell. 91:119-126.

242. Spector, S. A., R. Merrill, D. Wolf, and W. M. Dankner. 1992. Detection of human cytomegalovirus in plasma of AIDS patients during acute visceral disease by DNA amplification. J. Clin. Microbiol. 30:2359-2365.

243. Stagno, S., D. W. Reynolds, A. Tsiantos, D. A. Fuccillo, W. Long, and C. A. Alford. 1975. Comparative serial virologic and serologic studies of symptomatic and subclinical congenitally and natally acquired cytomegalovirus infections. J. Infect. Dis. 132:568-577.

244. Stals, F. S., F. Bosman, C. P. van Boven, and C. A. Bruggeman. 1990. An animal model for therapeutic intervention studies of CMV infection in the immunocompromised host. Arch. Virol. 114:91-107.

245. Stein, J., H. D. Volk, C. Liebenthal, D. H. Kruger, and S. Prosch. 1993. Tumour necrosis factor alpha stimulates the activity of the human cytomegalovirus major immediate early enhancer/promoter in immature monocytic cells. J. Gen. Virol. 74:2333-2338. 
246. Stenberg, R. M., D. R. Thomsen, and M. F. Stinski. 1984. Structural analysis of the major immediate early gene of human cytomegalovirus. J. Virol. 49:190-199.

247. Stoddart, C. A., R. D. Cardin, J. M. Boname, W. C. Manning, G. B. Abenes, and E. S. Mocarski. 1994. Peripheral blood mononuclear phagocytes mediate dissemination of murine cytomegalovirus. J. Virol. 68:6243-6253.

248. Tanabe, K., T. Tokumoto, N. Ishikawa, I. Koyama, K. Takahashi, S. Fuchinoue, T. Kawai, S. Koga, T. Yagisawa, H. Toma, K. Ota, and H. Nakajima. 1997. Comparative study of cytomegalovirus (CMV) antigenemia assay, polymerase chain reaction, serology, and shell vial assay in the early diagnosis and monitoring of CMV infection after renal transplantation. Transplantation. 64:1721-1725.

249. Tanaka, N., H. Kimura, K. Iida, Y. Saito, I. Tsuge, A. Yoshimi, T. Matsuyama, and T. Morishima. 2000. Quantitative analysis of cytomegalovirus load using a real-time PCR assay. J. Med. Virol. 60:455-462.

250. Taylor Wiedeman, J., G. P. Hayhurst, J. G. Sissons, and J. H. Sinclair. 1993. Polymorphonuclear cells are not sites of persistence of human cytomegalovirus in healthy individuals. J. Gen. Virol. 74:265-268.

251. Taylor Wiedeman, J., J. G. Sissons, L. K. Borysiewicz, and J. H. Sinclair. 1991. Monocytes are a major site of persistence of human cytomegalovirus in peripheral blood mononuclear cells. J. Gen. Virol. 72:2059-2064.

252. Taylor Wiedeman, J., P. Sissons, and J. Sinclair. 1994. Induction of endogenous human cytomegalovirus gene expression after differentiation of monocytes from healthy carriers. J. Virol. 68:1597-1604.

253. The, T. H., M. van der Ploeg, A. P. van den Berg, A. M. Vlieger, M. van der Giessen, and W. J. van Son. 1992. Direct detection of cytomegalovirus in peripheral blood leukocytes-a review of the antigenemia assay and polymerase chain reaction. Transplantation. 54:193-198.

254. Toorkey, C. B., and D. R. Carrigan. 1989. Immunohistochemical detection of an immediate early antigen of human cytomegalovirus in normal tissues. J. Infect. Dis. 160:741-751.

255. Toyoda, M., J. B. Carlos, O. A. Galera, K. Galfayan, X. Zhang, Z. Sun, L. S. Czer, and S. C. Jordan. 1997. Correlation of cytomegalovirus DNA levels with response to antiviral therapy in cardiac and renal allograft recipients. Transplantation. 63:957-963.

256. Turgeon, N., J. A. Fishman, N. Basgoz, N. E. Tolkoff Rubin, M. Doran, A. B. Cosimi, and R. H. Rubin. 1998. Effect of oral acyclovir or ganciclovir therapy after preemptive intravenous ganciclovir therapy to prevent cytomegalovirus disease in cytomegalovirus seropositive renal and liver transplant recipients receiving antilymphocyte antibody therapy. Transplantation. 66:1780-1786.

257. Turtinen, L. W., R. Saltzman, M. C. Jordan, and A. T. Haase. 1987. Interactions of human cytomegalovirus with leukocytes in vivo: analysis by in situ hybridization. Microb. Pathog. 3:287-297.

258. van den Berg, A. P., I. J. Klompmaker, B. G. Hepkema, A. S. Gouw, E. B. Haagsma, S. P. Lems, T. H. The, and M. J. Slooff. 1996. Cytomegalovirus infection does not increase the risk of vanishing bile duct syndrome after liver transplantation. Transpl. Int. 9 Suppl. 1:S171-S173. 
259. van den Berg, A. P., W. J. van Son, E. B. Haagsma, I. J. Klompmaker, A. M. Tegzess, J. Schirm, G. Dijkstra, M. van der Giessen, M. J. Slooff, and T. H. The. 1993. Prediction of recurrent cytomegalovirus disease after treatment with ganciclovir in solid-organ transplant recipients. Transplantation. 55:847-851.

260. van den Berg, A. P., W. Ven der Bij, W. J. Van Son, J. Anema, M. Van der Giessen, J. Schirm, A. M. Tegzess, and T. H. The. 1989. Cytomegalovirus antigenemia as a useful marker of symptomatic cytomegalovirus infection after renal transplantation- a report of 130 consecutive patients. Transplantation. 48:991-995.

261. van der Bij, W., J. Schirm, R. Torensma, W. J. van Son, A. M. Tegzess, and T. H. The. 1988. Comparison between viremia and antigenemia for detection of cytomegalovirus in blood. J. Clin. Microbiol. 26:2531-2535.

262. van Son, W. J., A. P. van den Berg, T. H. The, and A. M. Tegzess. 1993. Preemptive therapy with gancyclovir for early high-risk CMV infection allows effective treatment with antithymocyte globulin of steroid-resistant rejection after renal transplantation. Transplant. Proc. 25:1436-1438.

263. Vanpoucke, H., B. Van Vlem, R. Vanholder, and L. Van Renterghem. 1999. Significance of qualitative polymerase chain reaction combined with quantitation of viral load in the diagnosis and follow-up of cytomegalovirus infection after solid-organ transplantation. Intervirology. 42:398-404.

264. Velzing, J. P. H. Rothbarth, A. C. Kroes, and W. G. Quint. 1994. Detection of cytomegalovirus mRNA and DNA encoding the immediate early gene in peripheral blood leukocytes from immunocompromised patients. J. Med. Virol. 42:164-169.

265. Vink, C., E. Beuken, and C. A. Bruggeman. 2000. Complete DNA sequence of the rat cytomegalovirus genome. J. Virol. 74:7656-7665.

266. von Laer, D., A. Serr, U. Meyer Konig, G. Kirste, F. T. Hufert, and O. Haller. 1995. Human cytomegalovirus immediate early and late transcripts are expressed in all major leukocyte populations in vivo. J. Infect. Dis. 172:365-370.

267. Wagner, J. A., H. Ross, S. Hunt, P. Gamberg, H. Valantine, T. C. Merigan, and E. B. Stinson. 1995. Prophylactic ganciclovir treatment reduces fungal as well as cytomegalovirus infections after heart transplantation. Transplantation. 60:1473-1477.

268. Weinberg, A., T. N. Hodges, S. Li, G. Cai, and M. R. Zamora. 2000. Comparison of PCR, antigenemia assay, and rapid blood culture for detection and prevention of cytomegalovirus disease after lung transplantation. J. Clin. Microbiol. 38:768-772.

269. Weir, M. R., M. L. Henry, M. Blackmore, J. Smith, M. R. First, B. Irwin, S. Shen, G. Genemans, J. W. Alexander, R. J. Corry, and et. al. 1988. Incidence and morbidity of cytomegalovirus disease associated with a seronegative recipient receiving seropositive donor-specific transfusion and living-related donor transplantation. A multicenter evaluation. Transplantation. 45:111-116.

270. Weller, T. H., J. C. Macaulay, J. M. Craig, and P. Wirth. 1957. Isolation of intranuclear inclusion producing agents from infants with illnesses resembling cytomegalic inclusion disease. Proc. Soc. Exp. Biol. Med. 94:4-12.

271. White, K. L., B. Slobedman, and E. S. Mocarski. 2000. Human cytomegalovirus latencyassociated protein pORF94 is dispensable for productive and latent infection. J. Virol. 74:93339337. 
272. Wingard, J. R., S. Piantadosi, W. H. Burns, M. L. Zahurak, G. W. Santos, and R. Saral. 1990. Cytomegalovirus infections in bone marrow transplant recipients given intensive cytoreductive therapy. Rev. Infect. Dis. 12 Suppl. 7:S793-804.

273. Winston, D. J., W. G. Ho, K. Bartoni, and R. E. Champlin. 1993. Intravenous immunoglobulin and CMV-seronegative blood products for prevention of CMV infection and disease in bone marrow transplant recipients. Bone Marrow Transplant. 12:283-288.

274. Winston, D. J., W. G. Ho, and R. E. Champlin. 1990. Cytomegalovirus infections after allogeneic bone marrow transplantation. Rev. Infect. Dis. 12 Suppl. 7:S776-792.

275. Yilmaz, S., P. K. Koskinen, E. Kallio, C. A. Bruggeman, P. J. Hayry, and K. B. Lemstrom. 1996. Cytomegalovirus infection-enhanced chronic kidney allograft rejection is linked with intercellular adhesion molecule-1 expression. Kidney Int. 50:526-537.

276. Yu, Y., S. C. Henry, F. Xu, and J. D. Hamilton. 1995. Expression of a murine cytomegalovirus early-late protein in "latently" infected mice. J. Infect. Dis. 172:371-379.

277. Yuhasz, S. A., V. B. Dissette, M. L. Cook, and J. G. Stevens. 1994. Murine cytomegalovirus is present in both chronic active and latent states in persistently infected mice. Virology. 202:272280.

278. Yun, Z. B., I. Lewensohn Fuchs, P. Ljungman, and A. Vahlne. 2000. Real-time monitoring of cytomegalovirus infections after stem cell transplantation using the TaqMan polymerase chain reaction assays. Transplantation. 69:1733-1736.

279. Zhuravskaya, T., J. P. Maciejewski, D. M. Netski, E. Bruening, F. R. Mackintosh, and S. St Jeor. 1997. Spread of human cytomegalovirus (HCMV) after infection of human hematopoietic progenitor cells: model of HCMV latency. Blood. 90:2482-2491.

280. Zipeto, D., M. G. Revello, E. Silini, M. Parea, E. Percivalle, M. Zavattoni, G. Milanesi, and G. Gerna. 1992. Development and clinical significance of a diagnostic assay based on the polymerase chain reaction for detection of human cytomegalovirus DNA in blood samples from immunocompromised patients. J. Clin. Microbiol. 30:527-530. 


\title{
Diagnostic Value of Monitoring Human Cytomegalovirus Late pp67 mRNA Expression in Renal-Allograft Recipients by Nucleic Acid Sequence-Based Amplification
}

\author{
MARINUS J. BLOK, ${ }^{1}$ VALERE J. GOOSSENS, ${ }^{1}$ SABINA J. V. \\ VANHERLE, ${ }^{1}$ BERT TOP, ${ }^{2}$ NICOLE TACKEN, ${ }^{2}$ JAAP M. \\ MIDDELDORP, ${ }^{2}$ MAARTEN H. L. CHRISTIAANS, ${ }^{3}$ JOHANNES \\ P. VAN HOOFF, ${ }^{3}$ AND CATHRIEN A. BRUGGEMAN ${ }^{1}$
}

Departments of Medical Microbiology ${ }^{1}$ and Internal Medicine, ${ }^{3}$ University Hospital Maastricht, 6202 AZ Maastricht, and Organon Teknika B.V., 5280 $A B$ Boxtel, ${ }^{2}$ The Netherlands

Journal of Clinical Microbiology, May 1998, Vol. 36(5), p. 1341-1346 
CHAPTER 2 


\section{ABSTRACT}

The diagnostic value of monitoring human cytomegalovirus (HCMV) late pp67 mRNA expression by nucleic acid sequence-based amplification (NASBA) after renalallograft transplantation was evaluated. RNAs were isolated from 489 whole-blood specimens of 42 patients for the specific amplification of the late pp67 (UL65) mRNA. NASBA results were compared to results from the pp65 antigenemia assay, virus isolation by cell culture, and serology. The sensitivity value for NASBA proved to be higher than that for the antigenemia assay ( 50 versus $35 \%$ ) for the detection of HCMV infection, while the sensitivity values of cell culture and NASBA were comparable (54 and $50 \%$, respectively). NASBA detected the onset of HCMV infection simultaneously with cell culture and the antigenemia assay. Both the antigenemia assay and NASBA are very specific $(100 \%)$ and highly predictive $(100 \%)$ for the onset of HCMV infection. Antiviral therapy with ganciclovir resulted in negative results for cell culture, the antigenemia assay, and NASBA. In conclusion, monitoring HCMV pp67 mRNA expression by NASBA is a highly specific method for the detection of HCMV infection in renal-allograft recipients and is more sensitive than the antigenemia assay. Furthermore, NASBA can be used to monitor the progression of HCMV infections and the effect of antiviral therapy on viral activity. 


\section{INTRODUCTION}

Human cytomegalovirus (HCMV) belongs to the group of betaherpesviruses. Primary infection of immunocompetent individuals with HCMV usually does not lead to complications. In contrast, immunocompromised patients, like AIDS and transplantation patients, may suffer severe complications during primary infection and to a lesser degree during secondary infection. In fact, HCMV infections are the most common single cause of death in allograft recipients (9). Detection of HCMV at an early stage of infection is a prerequisite for effective preemptive antiviral therapy (22). Currently, several routine diagnostic tests are available for the direct or indirect detection of HCMV infection. Direct isolation of HCMV by cultivation of permissive human fibroblasts with samples from blood or urine is a sensitive method, but results are obtained rather late. The cytopathic effects (CPE) of replicating virus in the cells can be detected only after several days or weeks of cultivation. The presence of virus can be detected much earlier in cell cultures by detection of early-antigen fluorescent foci (DEAFF) with monoclonal antibodies directed against immediate-early 1 antigen of the virus (8). Although the cell culture assay was previously considered the "gold standard," the HCMV antigenemia assay is more commonly used to monitor patients for HCMV disease. The antigenemia assay was developed by Van der Bij et al. (29) to detect the viral lower matrix protein pp65 (UL83) in blood leukocytes. By this immunocytochemical technique, test results can be obtained within 1 day, but it requires direct processing of fresh clinical specimens. The number of pp65-positive cells was shown to correlate with HCMV disease $(26,28)$. PCR is another method to detect the presence of HCMV. Although amplification of the viral genome by PCR proved to be a highly sensitive technique (up to $100 \%$ ), it does not necessarily correlate with active infection, due to the possible amplification of latently present viral DNA and/or incomplete viral genomes $(17,24,27)$. It was suggested that the detection of viral immediate-early and late mRNAs in blood leukocytes may improve HCMV diagnosis (1), as it directly reflects viral transcriptional activity. Indeed, reverse transcriptase PCR (RT$\mathrm{PCR}$ ) of viral late mRNA was found to have a high positive predictive value for HCMV disease, although sensitivity appeared to be low $(6,16,21)$. The detection of mRNA by nucleic acid sequence-based amplification (NASBA) is a highly sensitive method. Unlike RT-PCR, NASBA allows detection of unspliced mRNA in a background of DNA (3). A qualitative and quantitative NASBA assay is currently available for the detection of human immunodeficiency virus (HIV) RNA $(10,30)$. The technique has now been used for the detection of HCMV RNA in blood leukocytes. In contrast to the methods just mentioned, serological diagnosis gives only indirect evidence of the presence of the virus and can be problematic because of the immunological disorders occurring in most patients at risk of 
developing HCMV infection (13, 23). However, detection of HCMV-specific antibodies can provide supportive evidence for the diagnosis of HCMV infection. Detection of immunoglobulin M (IgM) especially can be used as a diagnostic tool during both primary and secondary infections $(7,12)$.

Using a qualitative NASBA assay, we evaluated retrospectively the diagnostic value of monitoring late pp67 mRNA expression as a marker for HCMV infections after renalallograft transplantation. The results of the NASBA assay were compared with the results of prospectively performed standard virological techniques, i.e., detection of the presence of infectious virus in blood by cell culture (CPE and DEAFF), testing for pp65 antigenemia, and serology.

\section{MATERIALS AND METHODS}

Patients. From January 1995 to July 1996, a total of 60 kidney transplantations were carried out at the Department of Internal Medicine, University Hospital Maastricht. For this study, we selected 42 patients, from whom a minimum of four blood specimens were collected during the first three months after transplantation. Patients could be grouped according to the HCMV serostatus of the recipient before transplantation and the HCMV serostatus of the donor, which resulted in the following distribution of patients with different serogroups: $13 \mathrm{D}+$ and $\mathrm{R}+$ patients, $8 \mathrm{D}+$ and $\mathrm{R}$ - patients, $13 \mathrm{D}$ - and $\mathrm{R}+$ patients, and 8 D- and R-patients, where D+ and D- indicate seropositive and -negative donors, respectively, and $\mathrm{R}+$ and $\mathrm{R}$ - indicate seropositive and -negative recipients, respectively.

Maintenance of immunosuppression consisted of treatment with cyclosporin or tacrolimus together with low-dose prednisolone. In addition, some patients received azathioprine. Allograft rejection was assessed clinically and confirmed by needle core biopsy. Treatment for allograft rejection consisted of a 10-day course of rabbit antilymphocyte globulin (National Institute of Public Health and the Environment, Bilthoven, The Netherlands) or three doses of methyl-prednisolone.

$\mathrm{HCMV}$ infection was defined by positive results for at least two samples for one or more of the following items: cell culture, antigenemia, seroconversion of anti-HCMV IgM, and/or a significant rise (at least fourfold) in the anti-HCMV IgG level compared to the pretransplantation titer. HCMV infection could be further classified as a primary or secondary infection, depending on whether the patient was HCMV seronegative or seropositive before transplantation, respectively.

Ganciclovir (Cymevene; Hoffmann-La Roche Ltd., Basel, Switzerland) was given intravenously for 2 weeks, in case HCMV infection was detected and the patient showed clinical signs suggesting HCMV disease. The perioperative protocol did not include 
routinely prophylactic anti-HCMV therapy. If possible, the dosage of the immunosuppressive drug was diminished in case of HCMV infection. However, if a patient was treated with ATG or methylprednisolone and HCMV infection was indicated by positive laboratory tests, ganciclovir was given for 2 weeks intravenously, even when there were no clinical signs of HCMV disease.

Specimens. Heparinized whole-blood and serum specimens were collected weekly during the clinical period after transplantation. After this period specimens were collected monthly or more frequently if the patient showed clinical symptoms of HCMV infection. Specimens were screened prospectively for the presence of HCMV by routine cell culture and the pp65 antigenemia assay. In addition, $1 \mathrm{ml}$ of heparinized blood was added to $9 \mathrm{ml}$ of NASBA lysis buffer (4.7 M guanidium thiocyanate, $46 \mathrm{mM}$ Tris [pH 6.4], $20 \mathrm{mM}$ EDTA, $1.2 \%$ [wt/vol] Triton $\mathrm{X}-100)$, and the mixture was stored at $-70^{\circ} \mathrm{C}$. From the 42 patients, a total of 489 blood specimens was collected.

Cell culture. For the detection of infectious HCMV in blood, both conventional cell culture and DEAFF were performed as described previously (11). Briefly, leukocytes were separated from heparinized whole blood with dextran and screened for the presence of HCMV by inoculation of human embryo fibroblasts monolayers. Cell cultures were observed weekly during a period of 6 weeks for the appearance of a typical CPE of replicating HCMV. DEAFF was performed after 2 days of cultivation with the monoclonal antibody E13 (Biosoft, Paris, France) to the HCMV immediate-early 1 antigen. For analysis, DEAFF and CPE results were combined to give one outcome for the cell culture assay. Results are presented for either the day on which a positive specimen was obtained or the day on which a positive result could be reported to the clinic.

pp65 antigenemia assay. The pp65 antigen was detected immunocytochemically essentially as described by Van der Bij et al. (29). Briefly, $45 \times 10^{4}$ leukocytes were isolated from heparinized whole blood with dextran and centrifuged onto a glass slide within $4 \mathrm{~h}$ of collection. The cells were subsequently fixed for $10 \mathrm{~min}$ in methanol and incubated with mouse monoclonal antibodies, namely, anti-pp65 IgG (produced in our laboratory). After incubation with horseradish peroxidase-coupled rabbit anti-mouse IgG (DAKO A/S, Glostrup, Denmark), the substrate 3-amino-9-ethylcarbazole was added to stain the pp65positive cells. Finally, slides were examined microscopically. Results are expressed as numbers of pp65-positive cells per $15 \times 10^{4}$ leukocytes.

Serology. Sera were tested retrospectively to obtain more information about viral activity, in addition to the antigenemia assay and cell culture results. For the qualitative detection of IgM against HCMV in serum, the IMx CMV assay (Abbott Laboratories, North Chicago, Ill.) was used, and for the semiquantitative detection of IgG against HCMV, the 
AXSym assay (Abbott Laboratories) was used. Both tests are based on microparticle enzyme immunoassay technology. Results from the IMx CMV assay were expressed as index values. Sera with index values of $\geq 0.500$ were considered positive. Levels of antiHCMV IgG were expressed as numbers of antibody units (AU) per milliliter. Sera with IgG levels of $\geq 15 \mathrm{AU} / \mathrm{ml}$ were considered positive. The detection limit of $250 \mathrm{AU} / \mathrm{ml}$ could be obtained for sera with high levels of IgG.

NASBA SC RNA. A transcription vector was constructed to generate system control (SC) RNA, which served as a positive control during isolation, amplification, and detection of RNA in the NASBA procedure. The vector was constructed essentially as described by Morré et al. (18). Briefly, part of the pp67 region from strain AD169 (nucleotides 95920 to 96247 ) was cloned into the vector $\mathrm{pG} 3 \mathrm{O}$, downstream of a T7 RNA polymerase promoter region. pG3O is a pGEM3 derivative (Promega, Madison, Wis.) lacking the Pstl and Sphl sites in the multiple-cloning sequence. In addition, a new BamHI site was introduced after the BamHI site in the multiple-cloning sequence was removed. A PstI site downstream of position 96073 and an SphI site upstream of position 96094 were generated by PCR for the insertion of an additional DNA sequence. This 134-bp fragment, with 5' Pstl and 3' SphI ends, comprised nucleotides 1015 to 1146 from the $5^{\prime}$ noncoding region of the HIV-1 pv22 sequence (19). This resulted in a plasmid from which the 20-bp wild-type HCMV sequence was deleted and replaced by the 134-bp HIV-1 pv22 fragment. This plasmid was linearized with BamHI, and in vitro RNA was generated by using T7 RNA polymerase (25). The RNA was treated with DNase I to remove plasmid DNA and purified on an anionic-exchange column (Qiagen, Leusden, The Netherlands). The recovered in vitro-generated SC RNA was quantified spectrophotometrically and stored at $-70^{\circ} \mathrm{C}$.

Nucleic acid isolation for NASBA. For analysis, $1 \mathrm{ml}$ of the lysed-whole-blood suspension, which equals $100 \mu \mathrm{l}$ of whole-blood input sample, was used. Twenty microliters of SC RNA containing 3,000 copies of pp67 SC RNA in $1.0 \mathrm{mM}$ Tris buffer, pH 8.5 , was added. Nucleic acid isolation was performed essentially as described by Boom et al. (2). Briefly, lysates were incubated with $50 \mu \mathrm{l}$ of activated silica $(0.4 \mathrm{~g}$ of suspension in $0.1 \mathrm{~N} \mathrm{HCl}$ per $\mathrm{ml}$ ). Subsequently, the silica particles carrying adsorbed nucleic acids were washed twice with $1 \mathrm{ml}$ of wash buffer $(5.25 \mathrm{M}$ guanidium thiocyanate, $50 \mathrm{mM}$ Tris IpH 6.4]), twice with $1 \mathrm{ml}$ of $70 \%$ ethanol, and once with $1 \mathrm{ml}$ of acetone. Finally, after the silica was dried at $56^{\circ} \mathrm{C}$ for $10 \mathrm{~min}$, the nucleic acids were eluted in $50 \mu \mathrm{l}$ of $1.0 \mathrm{mM}$ Tris buffer, $\mathrm{pH} 8.5$, and stored at $-20^{\circ} \mathrm{C}$.

Qualitative NASBA. The primers CMVpp67-1.2 and CMVpp67-2.4 were designed to amplify part of the mRNA encoding pp67 (Table 1). NASBA reactions were carried out as described by Kievits et al. (10), with minor modifications. Reactions were performed with 
TABLE 1. Sequences of NASBA primers and probes used, respectively, for amplification and detection of pp67 WT and SC RNAs

\begin{tabular}{lll}
\hline Oligonucleotide & \multicolumn{1}{c}{ Function } & \multicolumn{1}{c}{ Sequence } \\
\hline CMVPp67-1.2 & T7 primer & 5'-AATTCTAATACGACTCACTATAGGGAGAGGGTCGATTCAGACTGA-3' \\
CMVPp67-2.4 & Primer 2 & 5'-CTGGAGATATATGTTGACCA-3' \\
CMVPp67CAP1 & $\begin{array}{l}\text { Capture probe for WT } \\
\text { and SC RNAs }\end{array}$ & 5'-GGATTCGGACTTTCCGTTCGA-3' \\
CMVpp67ECL1 & ECL probe for WT RNA & 5'CCAAAAAGCTAGCCGTCACG-3' \\
SC-ECL1 & ECL probe for SC RNA & 5'-GAAAAAAGCACAGCAAGCAGCAGG-3' \\
\hline
\end{tabular}

a 20- $\mu \mathrm{l}$ reaction mixture containing $40 \mathrm{mM}$ Tris ( $\mathrm{pH}$ 8.5; Sigma, St. Louis, Mo.); $12 \mathrm{mM}$ $\mathrm{MgCl}_{2}$ (Sigma); $70 \mathrm{mM} \mathrm{KCl}$ (Baker, Concord, Ontario, Canada); $15 \%$ (vol/vol) dimethyl sulfoxide (Sigma); $5 \mathrm{mM}$ dithiothreitol (Sigma); $1 \mathrm{mM}$ each deoxynucleoside triphosphate (Pharmacia, Uppsala, Sweden); 2 mM ATP, CTP, and UTP; 1.5 mM GTP (Pharmacia); 0.5 mM ITP (Boehringer, Mannheim, Germany); $2 \mu \mathrm{g}$ of bovine serum albumin (Boehringer); $0.08 \mathrm{U}$ of RNase H (Pharmacia); $32 \mathrm{U}$ of T7 RNA polymerase (Pharmacia); $6.4 \mathrm{U}$ of avian myeloblastosis RT (Seikagaku, Ijamsville, Md.); $0.2 \mu \mathrm{M}$ each primer; and $5 \mu \mathrm{l}$ of the isolated nucleic acids. The NASBA reaction mixtures were incubated for $5 \mathrm{~min}$ at $65^{\circ} \mathrm{C}$. before the enzymes were added, to allow destabilization of secondary RNA structures and subsequently cooled down for $5 \mathrm{~min}$ to $41^{\circ} \mathrm{C}$ to allow primer annealing. After the enzymes were added, reactions mixtures were incubated at $41^{\circ} \mathrm{C}$ for $90 \mathrm{~min}$ and subsequently stored at $-20^{\circ} \mathrm{C}$.

ECL-based detection. A twofold dilution of the amplification products was made in detection diluent $(1.0 \mathrm{mM}$ Tris $[\mathrm{pH} 8.5], 0.2 \mathrm{~g}$ of 2-methylisothiazolone $\mathrm{HCl}$ per liter). Subsequently, $5 \mu \mathrm{l}$ of the diluted amplification products (wild type [WT] and SC) was incubated for $30 \mathrm{~min}$ at $41^{\circ} \mathrm{C}$ with $0.084 \mu \mathrm{M}$ pp67 mRNA-specific biotine probe (CMVpp67CAP1) (Table 1) bound to $5 \mu \mathrm{g}$ of streptavidin-coated magnetic beads (mean diameter \pm standard deviation, $2.8 \pm 0.2 \mu \mathrm{m}$; Dynal, Great Neck, N.Y.) and $3 \times 10^{11}$ molecules of an electrochemiluminescence (ECL) complex (tris[2,2-bipyridine]ruthenium [II])-labeled oligonucleotide probe, specific for either pp67 WT RNA (CMVpp67ECL1) or SC RNA (SC-ECL1), in a total volume of $25 \mu \mathrm{l}$ of $5 \times \mathrm{SSC}$ ( $1 \times$ SSC is $0.15 \mathrm{M} \mathrm{NaCl}$ plus 0.015 $\mathrm{M}$ sodium citrate). As negative controls, detection diluent was also incubated with the different bead-oligonucleotide and ECL complex-probe mixtures for WT and SC RNA detection. During incubation, tubes were agitated every $10 \mathrm{~min}$ to keep the beads in suspension. Subsequently, $300 \mu \mathrm{l}$ of assay buffer solution ( $100 \mathrm{mM}$ tripropylamine, $\mathrm{pH} 7.5$ ) was added and the tubes were placed in an ECL detection instrument (NASBA QR system, model 2000; Organon Teknika B.V., Boxtel, The Netherlands). In order to check the instrument and to be able to compare ECL signals from different runs, a tube with reference 
solution containing $66.67 \mu \mathrm{g}$ of streptavidin-coated magnetic beads per $\mathrm{ml}$ in assay buffer solution was included. ECL signals for WT and SC RNA were adjusted with the values obtained for the reference solution [(ECL signal for reference solution $\left./ 40 \times 10^{3}\right) \times \mathrm{ECL}$ signal for WT or SC RNA] and for background signals (i.e., negative controls). ECL signals higher than $600\left(1.5 \%\right.$ of $\left.40 \times 10^{3}\right)$ were considered positive.

Statistical analysis. Statistical analysis was carried out by the Wilcoxon matched-pair signed-rank test. P values of $\leq 0.05$ were considered significant.

\section{RESULTS}

Incidence of $\mathrm{HCMV}$ infection and disease. A group of 42 patients was monitored for the occurrence of HCMV infection and HCMV disease after renal transplantation. Seropositive patients receiving a kidney from a seropositive donor showed the highest incidence of HCMV infection (85\% [11 of 13 patients]). For patients of the D+ and Rserogroup and those of the D- and R+ serogroup, the incidence of HCMV infection was $75 \%$ ( 6 of 8 patients) and $69 \%$ (9 of 13 patients), respectively. HCMV was not detected by any of the assays in blood samples from patients from the D- and R-serogroup. For four patients, HCMV disease was diagnosed according to the criteria of Metselaar (15), namely, fever for at least three consecutive days, leukocytopenia, thrombocytopenia, liver abnormalities, and organ involvement, and was confirmed by concomitant positive cell culture and/or antigenemia assay results. Three of these patients belonged to the D+and $\mathrm{R}$ - serogroup ( $38 \%$ [ 3 of 8 patients]), while one belonged to the $\mathrm{D}+$ and $\mathrm{R}+\operatorname{serogroup}(8 \%$ [1 of 13 patients]). All patients with HCMV disease underwent antiviral therapy with ganciclovir. Two additional patients received ganciclovir when HCMV infection was detected during treatment for rejection.

Detection of HCMV infection. HCMV infection could be classified as primary or secondary, depending on whether the patient was seronegative or seropositive before transplantation, respectively. In each patient with a primary infection $(n=6)$, HCMV was detected by cell culture, the antigenemia assay, and NASBA. In 20 patients, a secondary infection was detected. Forty percent of these infections were detected by cell culture, whereas $35 \%$ were detected by NASBA. The antigenemia assay appeared to be the leastsensitive assay (15\%).

A total of 489 blood specimens was collected from the 42 patients. In one sample, NASBA repeatedly failed to amplify both WT RNA and the added SC RNA. This result was considered invalid. Antigenemia assay results could be compared to NASBA results for 173 samples. In this study, we found $56 \%$ of the positive antigenemia results to be positive also by NASBA (Table 2). Of 141 antigenemia assay-negative samples, 134 were NASBA 
TABLE 2. pp67 NASBA results compared to antigenemia assay and cell culture results

\begin{tabular}{|c|c|c|c|c|}
\hline \multirow[t]{2}{*}{ Test } & \multirow[t]{2}{*}{ Result } & \multirow{2}{*}{$\begin{array}{l}\text { No. of test } \\
\text { samples }\end{array}$} & \multicolumn{2}{|c|}{$\begin{array}{l}\text { No. (\%) of test samples with indica- } \\
\text { ted result by pp67 NASBA }\end{array}$} \\
\hline & & & Positive & Negative \\
\hline \multirow[t]{3}{*}{ Antigenemia assay } & Positive & 32 & $18(56)$ & $14(44)$ \\
\hline & Negative & 141 & $7(5)$ & $134(95)$ \\
\hline & No result & 315 & $11(4)$ & $304(96)$ \\
\hline \multirow[t]{3}{*}{ Cell culture ${ }^{a}$} & Positive & 36 & $16(44)$ & $20(56)$ \\
\hline & Negative & 422 & $19(5)$ & 403 (95) \\
\hline & No result & 30 & $1(3)$ & $29(97)$ \\
\hline
\end{tabular}

$a$ DEAFF and CPE results were combined.

$b$ The total number of test samples was 488 ( 1 sample was invalid for NASBA).

negative (95\%). Cell culture and NASBA results could be compared for 458 of the 489 samples. Of 36 positive cell culture results, $44 \%$ were found to be positive by NASBA. There was $96 \%$ agreement of negative cell culture results with negative NASBA results.

Table 3 shows sensitivities, specificities, and positive and negative predictive values (PPV and NPV) of NASBA, the antigenemia assay, and cell culture for HCMV infection (see Materials and Methods for the criteria used to diagnose HCMV infection). The sensitivity values of NASBA (50\%) and cell culture $(54 \%)$ are comparable, while the sensitivity value of NASBA proved to be higher than that of the antigenemia assay: $50 \%$ versus $35 \%$. Comparable results were obtained for the NPV. Specificity and PPV of cell culture for HCMV infection were 94 and $93 \%$, respectively, whereas for NASBA and the antigenemia assay they were as high as $100 \%$.

Time of detection of HCMV infection. In this study, 26 of the 42 patients (62\%) developed signs of HCMV infection. The onset of HCMV infection was detected by NASBA at a median of 36 days after transplantation (range, 21 to 75 days). For the antigenemia assay and cell culture, detection occurred at 35 days (range, 28 to 69 days) and 65 days (range, 27 to 103 days), respectively. Results of NASBA and the antigenemia assay were

TABLE 3. Diagnostic values for the detection of HCMV infection by pp67 NASBA, cell culture, and the antigenemia assay ${ }^{a}$

\begin{tabular}{ccccc}
\hline \multicolumn{1}{c}{ Test } & \% Sensitivity & \% Specificity & \% PPV & \% NPV \\
\hline Pp67 NASBA & 50 & 100 & 100 & 55 \\
Cell culture & 54 & 94 & 93 & 56 \\
Antigenemia assay & 35 & 100 & 100 & 49 \\
\hline
\end{tabular}

a See Materials and Methods for the criteria used to diagnose HCMV infection. 
found to be positive for HCMV infection simultaneously in four cases, while results of the antigenemia assay indicated positivity earlier than those of NASBA in three cases. However, this difference appeared not to be statistically significant $(P=0.11)$. Results of NASBA were found to be positive before those of cell culture were found to be positive in seven cases, while results of cell culture were earlier in three cases. This difference also appeared not to be significant $(P=0.11)$. In five cases, results of the antigenemia assay were found to be positive before positive cell culture results could be reported to the clinic. Although this appears to be significant $(P=0.04)$, the numbers are low.

Figure 1 shows representative examples of NASBA results, compared to antigenemia assay, cell culture, and serology results. Patient I ( $D+$ and $R+$ ) was treated twice for rejection with methylprednisolone from days 18 to 22 and days 30 to 33 . The onset of HCMV infection was first detected at day 36 by the antigenemia assay, followed by NASBA at day 39. The first cell culture-positive result (CPE) could be reported to the clinic at day 76 (specimen was obtained at day 41). Serology confirmed the onset of a secondary infection, with a rise in IgM levels from day 33. No significant rise in IgG levels was detected because assay results were as high as the detection limit of $250 \mathrm{AU} / \mathrm{ml}$ during the tested period (results not shown). HCMV disease was not diagnosed, and the patient did not receive antiviral therapy with ganciclovir. By NASBA, pp67 mRNA was detected up to day 64 , while positive antigenemia assay and cell culture specimens were obtained up to day 71 . Patient II (D+ and R-) was also treated twice for rejection with methylprednisolon from days 9 to 13 and days 33 to 35 . The onset of HCMV infection was detected by the antigenemia assay and NASBA at day 29. A cell culture-positive specimen was also obtained at day 29 , although this result was not known before day 56 . Serology results indicated the onset of a primary infection, with seroconversion of $\operatorname{IgM}$ and $\operatorname{IgG}$ at days 33 and 40, respectively. HCMV was detected during the period that the patient was treated for rejection. In addition, the patient had fever at day 37, indicative of HCMV infection. Therefore, antiviral therapy with ganciclovir was started at day 37 and maintained until day 50, although HCMV disease was not diagnosed for this patient. During that period, the samples became antigenemia assay, cell culture, and NASBA negative.

\section{DISCUSSION}

In this study, we evaluated the diagnostic value of monitoring late pp67 mRNA expression by NASBA as a marker for HCMV infection. The expression of HCMV late mRNA, such as pp67 (UL65), in circulating blood leukocytes is considered to directly reflect HCMV replication and dissemination in the infected host and should cease upon effective blockage of viral polymerase by antiviral agents, such as ganciclovir (14). The mRNA 

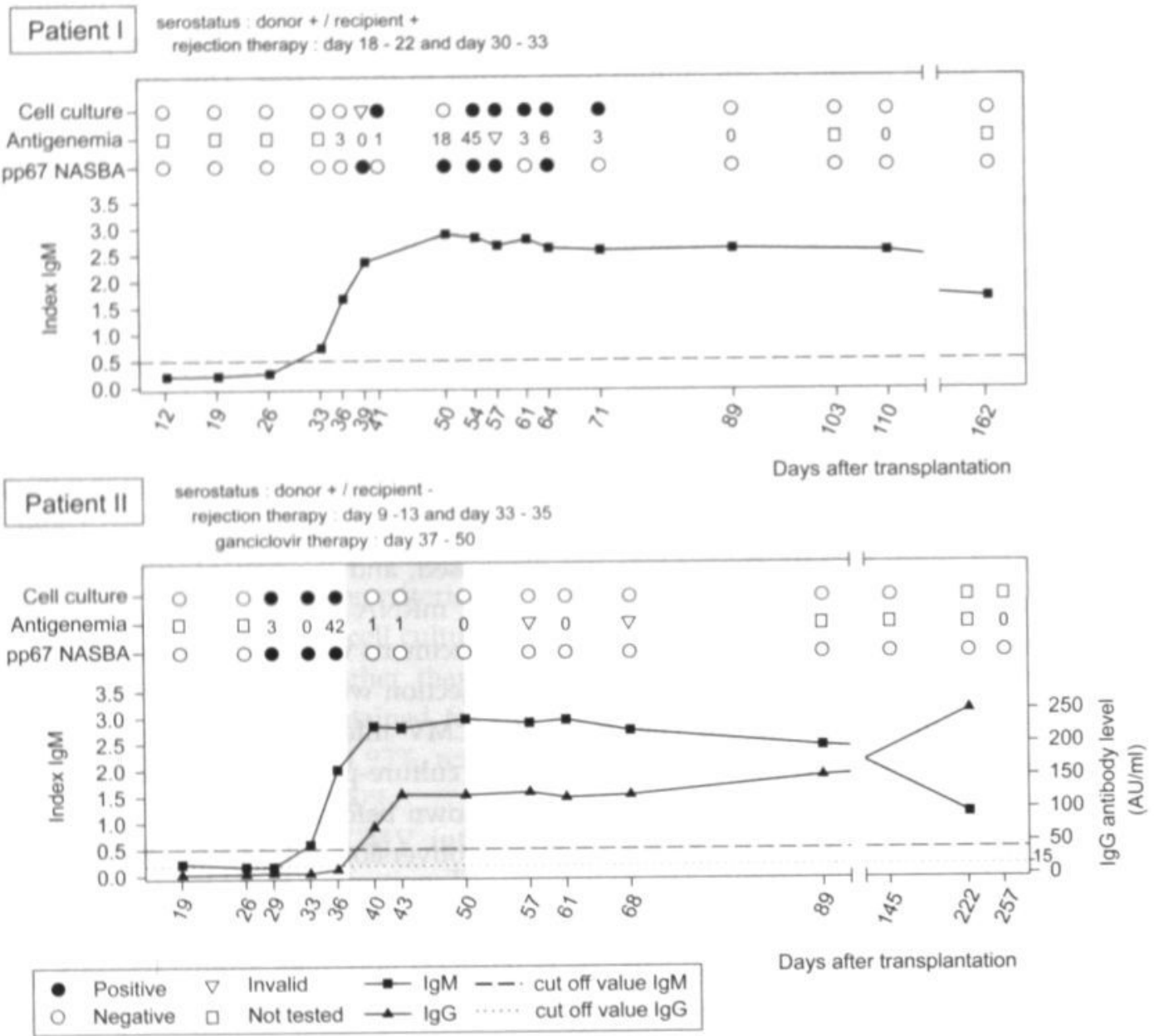

Days after transplantation

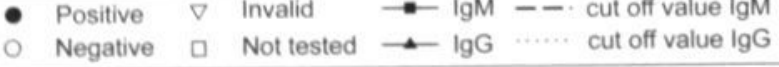

Days after transplantation

FIG. 1. Detection of HCMV in patients after renal-allograft transplantation by pp67 NASBA, antigenemia, cell culture, and serological assays. HCMV infection was diagnosed for both patient I and patient II after a period of therapy for allograft rejection. Antiviral therapy with ganciclovir was initiated for patient II (indicated by the shaded area), because the patient had fever and HCMV was detected during a period of rejection therapy with methylprednisolone. However, the patient did not meet the criteria for diagnosis of HCMV disease. Antigenemia results are expressed as numbers of positive cells $/ 15 \times 10^{4}$ leukocytes. DEAFF and CPE results were combined to give one outcome for the cell culture assay. Cell culture results are given for the day on which the sample was taken from the patient. 
encoding the viral structural protein pp67 is one of the most abundant late transcripts (5). It was suggested that pp67 may have important functions in the replication cycle of HCMV, such as protein kinase activity, DNA binding, and possible transcriptional activity of immediate-early genes (4). In contrast to what occurs in RT-PCR, the unspliced pp67 mRNA can be specifically amplified by NASBA in a background of DNA (3).

We evaluated the sensitivity of pp67 NASBA by testing blood specimens collected from 42 patients after renal-allograft transplantation. HCMV infection is defined in Materials and Methods. According to this definition, the combined results for cell culture (CPE and DEAFF), the antigenemia assay, and serology are considered the gold standard for the calculation of the sensitivity, specificity, and PPV and NPV of the NASBA assay. For 26 patients $(62 \%)$ HCMV infection was diagnosed according to these criteria, and 4 of these patients (15\%) developed HCMV disease.

Table 2 shows that $44 \%$ of antigenemia assay-positive samples were NASBA negative. It should be noted, however, that for all these samples, only weakly positive antigenemia assay results had been obtained ( 1 to 3 positive cells $/ 15 \times 10^{4}$ leukocytes). Furthermore, for all patients in whom HCMV infection was detected by the antigenemia assay, the results of NASBA were also found to be positive. Importantly, for four patients, HCMV infection was detected by NASBA but not by the antigenemia assay, which resulted in a higher sensitivity value for the NASBA assay than for the antigenemia assay (50 versus $35 \%$ ). The sensitivity values of cell culture and the NASBA assay for HCMV infection were comparable (54 and $50 \%$, respectively), although $56 \%$ of cell culture-positive samples were NASBA negative (Table 2). However, cell cultures were maintained for a minimum of 21 days before being reported as CPE negative, or for 2 days in case of DEAFF, while the NASBA assay can be performed in 1 day. In addition, there appears to be no significant difference between the moment at which positive cell culture results can be reported to the clinic and the moment at which HCMV infection is detected by NASBA. Furthermore, results of NASBA and the antigenemia assay were also found positive simultaneously. It should be noted, however, that the results of the statistical analysis in this study are based on low numbers.

pp67 NASBA was also evaluated as a prognostic marker of HCMV disease in thoracic organ transplant recipients (20). A PPV of $100 \%$ was found for HCMV disease. Also, NASBA-positive results occurred in $84 \%$ of cases before a clinically significant number of antigenemia assay-positive results occurred ( $>10$ positive cells $/ 2 \times 10^{5}$ leukocytes). In our study, only four patients developed HCMV disease. HCMV infection in these patients was detected by all assays.

Six patients received ganciclovir to treat HCMV infection. Figure 1 shows the data for one of these patients (patient II). Ganciclovir therapy was started at day 37, while the 
patient was being treated for rejection and had fever suggesting HCMV infection, confirmed by concomitant positive antigenemia assay results (the first cell culture-positive result was not known before day 56). Results of NASBA were found to be positive simultaneously with those of the antigenemia assay, which demonstrates that pp67 NASBA results can be conclusive enough for the clinician to initiate antiviral therapy. Antiviral therapy was sustained for 2 weeks. During that period, leukocytes became pp65 antigen negative. Comparatively, pp67 mRNA expression was no longer detected. Thus, reduction of viral activity can also be monitored by pp67 NASBA, which was expected, because ganciclovir inhibits replication by acting on the viral DNA polymerase (14) while late mRNAs, including pp67 mRNA, are transcribed only after replication of the viral genome. Patient I was not treated with ganciclovir. However, negative cell culture and antigenemia assay results after day 71 indicated reduction of viral activity. Again, NASBA results were comparable to cell culture and antigenemia assay results.

Meyer-König et al. (16) and Bitsch et al. (1) used RT-PCR to detect immediate-early and late pp150 mRNAs in the pheripheral blood leukocytes of renal-allograft recipients. Bitsch et al. found immediate-early mRNA to be present in almost every patient with HCMV infection. Late pp150 mRNA was detected only in leukocytes from a patient with HCMV disease who showed very high numbers of pp65-antigen-positive cells. Meyer-König et al. also found the presence of HCMV mRNA to correlate positively with the number of pp65antigen-positive cells. However, their RT-PCR assay was not superior to the pp65 antigenemia test for diagnosis and monitoring of HCMV disease.

The NASBA assay offers some practical advantages compared to other tests. For example, $100 \mu \mathrm{l}$ of whole blood is sufficient to perform one NASBA assay. The blood sample does not need to be processed before uptake in the NASBA lysis buffer. In addition, it is possible to store whole-blood samples in NASBA lysis buffer at $-70^{\circ} \mathrm{C}$ until they are needed for further processing for nucleic acid isolation. For the antigenemia assay, leukocytes have to be isolated from the whole-blood sample within a few hours after it is taken from the patient. The pp67 NASBA assay will be commercially available as a ready-to-use kit, named the NucliSens CMV pp67 assay kit (Organon Teknika B.V.) and will contain all primer and enzyme mixes needed. One person can perform the NASBA assay for 20 blood samples in 1 day, using the kit and the ECL detection instrument. In the near future it will also be possible to use an automated extraction instrument for isolation of nucleic acids from blood samples, with which more blood samples can be handled in 1 day.

From our study it can be concluded that NASBA of late pp67 mRNA is more sensitive than the antigenemia assay for the detection of HCMV infection in renal-allograft recipients. Both the antigenemia assay and pp67 NASBA are very specific and highly 
predictive of the onset of HCMV infection. Furthermore, pp67 NASBA can be used to monitor progression of $\mathrm{HCMV}$ infections and the effect of antiviral therapy, with results comparable to those of the antigenemia assay. Alternatively, detection and monitoring of immediate-early or early antigen mRNA expression by NASBA may provide an additional protocol for early identification of infection. Such studies are in progress.

\section{ACKNOWLEDGMENT}

We thank Kees Vink for reading the manuscript critically and for helpful discussions. 


\section{REFERENCES}

1. Bitsch, A., H. Kirchner, R. Dupke, and G. Bein. 1993. Cytomegalovirus transcripts in peripheral blood leukocytes of actively infected transplant patients detected by reverse transcriptionpolymerase chain reaction. J. Infect. Dis. 167:740-743.

2. Boom, R., C. J. A. Sol, M. M. M. Salimans, C. L. Jansen, P. M. E. Wertheim-van Dillen, and J. van der Noordaa. 1990. Rapid and simple method for purification of nucleic acids. J. Clin. Microbiol. 28:495-503.

3. Compton, J. 1991. Nucleic acid sequence-based amplification. Nature 350: 91-92.

4. Davis, M. G., and E.-S. Huang. 1985. Nucleotide sequence of a human cytomegalovirus DNA fragment encoding a 67-kilodalton phosphorylated viral protein. J. Virol. 56:7-11.

5. Davis, M. G., E.-C. Mar, Y.-M. Wu, and E.-S. Huang. 1984. Mapping and expression of a human cytomegalovirus major viral protein. J. Virol. 52:129-135.

6. Gozlan, J., J. P. Laporte, S. Lesage, M. Labopin, A. Najman, N. C. Gorin, and J. C. Petit. 1996. Monitoring of cytomegalovirus infection and disease in bone marrow recipients by reverse transcription-PCR and comparison with PCR and blood and urine cultures. J. Clin. Microbiol. 34:2085-2088.

7. Griffiths, P. D., S. Stagno, R. F. Pass, R. J. Smith, and C. A. Alford, Jr. 1982. Infection with cytomegalovirus during pregnancy: specific $\operatorname{IgM}$ antibodies as a marker of recent primary infection. J. Infect. Dis. 145:647-653.

8. Griffiths, P. D., P. R. Stirk, M. Ganczakowski, D. D. Panjwani, M. G. Ball, H. A. Blacklock, and H. G. Prentice. 1984. Rapid diagnosis of cytomegalovirus infection in immunocompromised patients by detection of early antigen fluorescent foci. Lancet ii:1242-1244.

9. Ho, M. 1994. Advances in understanding cytomegalovirus infection after transplantation. Transplant. Proc. 26:7-11.

10. Kievits, T., B. van Gemen, D. van Strijp, R. Schukkink, M. Dircks, H. Adriaanse, L. Malek, R. Sooknanan, and P. Lens. 1991. NASBA isothermal enzymatic in vitro nucleic acid amplification optimized for the diagnosis of HIV-1 infection. J. Virol. Methods 35:273-286.

11. Kraat, Y. J., M. H. L. Christiaans, F. H. M. Nieman, P. M. van de Berg, J. P. van Hooff, and C. A. Bruggeman. 1994. Risk factors for cytomegalovirus infection and disease in renal transplant recipients: HLA-DR7 and triple therapy. Transplant International 7:362-367.

12. Kraat, Y. J., F. S. Stals, M. H. Christiaans, T. Lazzarotto, M. P. Landini, and C. A. Bruggeman. 1996. IgM antibody detection of ppUL80A and ppUL32 by immunoblotting: an early parameter for recurrent cytomegalovirus infection in renal transplant recipients. J. Med. Virol. 48:289-294.

13. Landini, M. P., G. Mirolo, P. Coppolecchia, M. C. Re, and M. La Placa. 1986. Serum antibodies to individual cytomegalovirus structural polypeptides in renal transplant recipients during viral infection. Microbiol. Immunol. 30:683-695.

14. Matthews, T., and R. Boehme. 1988. Antiviral activity and mechanism of action of ganciclovir. Rev. Infect. Dis. 10(Suppl. 3):S490-S494.

15. Metselaar, H. J. 1990. Diagnosis and prevention of cytomegalovirus infection after organ transplantation. Ph.D. thesis. University of Rotterdam, Rotterdam, The Netherlands. 
16. Meyer-König, U., A. Serr, D. von Laer, G. Kirste, C. Wolff, O. Haller, D. Neumann Haefelin, and F. T. Hufert. 1995. Human cytomegalovirus immediate early and late transcripts in peripheral blood leukocytes: diagnostic value in renal transplant recipients. J. Infect. Dis. 171:705-709.

17. Miller, M. J., S. Bovey, K. Pado, D. A. Bruckner, and E. A. Wagar. 1994. Application of PCR to multiple specimen types for diagnosis of cytomegalovirus infection: comparison with cell culture and shell vial assay. J. Clin. Microbiol. 32:5-10.

18. Morré, S. A., P. Sillekens, M. V. Jacobs, P. van Aarle, S. de Blok, B. van Gemen, J. M. Walboomers, C. J. Meijer, and A. J. van den Brule. 1996. RNA amplification by nucleic acid sequence-based amplification with an internal standard enables reliable detection of Chlamydia trachomatis in cervical scrapings and urine samples. J. Clin. Microbiol. 34:3108-3114.

19. Muesing, M. A., D. H. Smith, C. D. Cabradilla, C. V. Benton, L. A. Lasky, and D. J. Capon. 1995. Nucleic acid structure and expression of the human AIDS/lymphadenopathy retrovirus. Nature (London) 313:450-458.

20. Oldenburg, N., K. M. C. Lam, B. Top, M. A. Khan, N. Tacken, G. W. Mikhail, N. R. Banner, and M. Yacoub. 1997. A novel strategy to monitor CMV immediate early and late gene expression as prognostic markers of CMV disease in thoracic organ transplant recipients using NASBA, abstr. 58, p. A-29. In Program and abstracts of the 6th International Cytomegalovirus Workshop.

21. Patel, R., T. F. Smith, M. Espy, D. Portela, R. H. Wiesner, R. A. Krom, and C. V. Paya. 1995. A prospective comparison of molecular diagnostic techniques for the early detection of cytomegalovirus in liver transplant recipients. J. Infect. Dis. 171:1010-1014.

22. Patel, R., D. R. Snydman, R. H. Rubin, M. Ho, M. Pescovitz, M. Martin, and C. V. Paya. 1996. Cytomegalovirus prophylaxis in solid organ transplant recipients. Transplantation 61:1279-1289.

23. Rasmussen, L., D. Kelsall, R. Nelson, W. Carney, M. Hirsch, D. Winston, J. Preisaitis, and T. C. Merican. 1982. Virus-specific IgG and IgM antibodies in normal and immunocompromised subjects infected with cytomegalovirus. J. Infect. Dis. 145:191-199.

24. Roseff, S. D., M. Rockis, J. F. Keiser, M. M. Caparas, J. Comerford, R. L. Sandin, and C. T. Garrett. 1993. Optimization for detection of cytomegalovirus by the polymerase chain reaction (PCR) in clinical samples. J. Virol. Methods 42:137-146.

25. Sambrook, J., E. F. Fritsch, and T. Maniatis. 1989. Molecular cloning: a laboratory manual, 2nd ed. Cold Spring Harbor Laboratory Press, Cold Spring Harbor, N.Y.

26. The, T. H., W. Van der Bij, A. P. Van den Berg, M. Van der Giessen, J. Weits, H. G. Sprenger, and W. J. Van Son. 1990. Cytomegalovirus antigenemia. Rev. Infect. Dis. 12:S737-S744.

27. The, T. H., M. van der Ploeg, A. P. van den Berg, A. M. Vlieger, M. van der Giessen, and W. J. van Son. 1992. Direct detection of cytomegalovirus in peripheral blood leukocytes - a review of the antigenemia assay and polymerase chain reaction. Transplantation 54:193-198.

28. Van den Berg, A. P., W. Ven der Bij, W. J. Van Son, J. Anema, M. Van der Giessen, J. Schirm, A. M. Tegzess, and T. H. The. 1989. Cytomegalovirus antigenemia as a useful marker of symptomatic cytomegalovirus infection after renal transplantation-a report of 130 consecutive patients. Transplantation 48:991-995. 
29. Van der Bij, W., J. Schirm, R. Torensma, W. J. van Son, A. M. Tegzess, and T. H. The. 1988. Comparison between viremia and antigenemia for detection of cytomegalovirus in blood. J. Clin. Microbiol. 26:2531-2535.

30. Van Gemen, B., R. van Beuningen, A. Nabbe, D. van Strijp, S. Jurriaans, P. Lens, and T. Kievits. 1994. A one-tube quantitative HIV-1 RNA NASBA nucleic acid amplification assay using electrochemiluminescent (ECL) labelled probes. J. Virol. Methods 49:157-167. 


\title{
Early Detection of Human Cytomegalovirus Infection after Kidney Transplantation by Nucleic Acid Sequence-Based Amplification
}

\author{
MARINUS J. BLOK, ${ }^{1}$ MAARTEN H.L. CHRISTIAANS, ${ }^{2}$ VALERE \\ J. GOOSSENS, ${ }^{1}$ JOHANNES P. VAN HOOFF, ${ }^{2}$ PETER \\ SILLEKENS, ${ }^{3}$ JAAP M. MIDDELDORP, ${ }^{3}$ AND CATHRIEN A. \\ BRUGGEMAN $^{1}$
}

Departments of Medical Microbiology ${ }^{1}$ and Internal Medicine, ${ }^{2}$ University Hospital Maastricht, 6202 AZ Maastricht; Organon Teknika B.V., 5280 AB Boxtel, ${ }^{3}$ The Netherlands

Transplantation, May 1999, Vol. 67(9), p. $1274-1277$ 
CHAPTER 3 


\begin{abstract}
Background. The early detection of human cytomegalovirus infection after organ transplantation is a prerequisite for effective antiviral therapy. We evaluated the diagnostic value of monitoring the viral immediate-early (IE) 1 mRNA expression in blood leukocytes by nucleic acid sequence-based amplification (NASBA).

Methods. Nucleic acids were isolated from 489 blood samples collected from $\mathbf{4 2}$ kidney transplant recipients and subjected to amplification by IE NASBA. The IE NASBA results were compared to those from pp67 NASBA, pp65 antigenemia, cell culture (DEAFF and CPE), and serology.

Results. IE NASBA proved to be the most sensitive assay which detected the onset of both primary and secondary cytomegalovirus infection significantly earlier than the other assays.

Conclusions. The early detection of cytomegalovirus infection with IE NASBA would enable the start of effective antiviral therapy at an early state of infection to prevent cytomegalovirus disease in patients at risk.
\end{abstract}




\section{INTRODUCTION}

In immunocompromised individuals such as neonates, and AIDS and transplantation patients, cytomegalovirus (CMV) infection can cause severe symptoms and even lead to death. Early detection of the onset of CMV infection after organ transplantation is a prerequisite for effective antiviral therapy to prevent CMV disease. Cell culture, pp65 antigenemia and serology are commonly used as diagnostic tools. In a previous study, we investigated the diagnostic value of nucleic acid sequence-based amplification (NASBA) for the detection of CMV. By this technique the viral pp67 late mRNA expression in blood leukocytes of kidney transplant recipients was monitored (1). We found pp67 NASBA to be more sensitive than the pp 65 antigenemia assay ( $50 \%$ vs. $35 \%)$. However, both assays were very specific (100\%) and detected the onset of infection simultaneously. The goal of this study was to investigate whether monitoring the expression of immediate-early (IE) 1 mRNA by NASBA, has additional value as a marker for CMV infection in kidney transplant recipients. The IE1 protein plays an essential role in the initiation of the viral lytic replication cycle (6). The mRNA encoding this protein is synthesized during the very early stages of viral lytic gene expression.

\section{MATERIALS AND METHODS}

A total of 60 patients received a kidney allograft during the period January 1995 to July 1996, at the Department of Internal Medicine, University Hospital Maastricht. For a group of 42 patients, a minimum of four bloodspecimens was collected during the first 3 months after transplantation. These patients were included in this study and were also used in the previous study for the evaluation of the pp67 NASBA assay (1). Twenty-six patients were seropositive before transplantation. Half of these patients received a kidney from a seropositive donor and the other half received a kidney from a seronegative donor. Eight patients were seronegative before transplantation, whereas the kidney originated from a seropositive donor. For eight other patients, both donor and recipient were seronegative. Maintenance immunosuppression consisted of treatment with cyclosporine or tacrolimus together with low-dose prednisolone.

CMV infection was defined by at least two positive results for one or more of the following items: cell culture, antigenemia, seroconversion of anti-CMV IgM, and/or a significant rise (at least four times) of anti-CMV IgG levels compared to the pretransplantation titer. CMV infections in patients who were either seronegative or seropositive before transplantation were designated as primary or secondary infections, respectively. CMV disease was defined according to the criteria of Metselaar et al. (4): fever 
for at least 3 consecutive days, leukocytopenia, thrombocytopenia, liver abnormalities and organ involvement, confirmed by concomitant positive cell culture and/or antigenemia results.

If a patient showed signs of CMV disease, ganciclovir was given i.v. for at least 2 weeks until two subsequent blood samples were negative for the antigenemia assay. The perioperative protocol did not include routinely prophylactic anti-CMV therapy. However, patients with a primary infection (D+, R-) also received ganciclovir during rejection therapy with antithymocyte globulin, even in the absence of clinical signs of CMV disease. In addition, all patients with positive antigenemia assay results during rejection also received ganciclovir.

Heparinized whole blood and serum specimens were collected weekly from the patients during hospitalization. After discharge, specimens were collected either monthly or more frequently, if the patient showed clinical symptoms of CMV infection. Specimens were screened prospectively for the presence of CMV by routine cell culture and the pp65antigenemia assay. In addition, $1 \mathrm{ml}$ of heparinized blood was added to $9 \mathrm{ml}$ of NASBA lysis buffer (4.7 M guanidinium thiocyanate; $46 \mathrm{mM}$ Tris, $\mathrm{pH} 6.4 ; 20 \mathrm{mM}$ EDTA; $1.2 \% \mathrm{w} / \mathrm{v}$ Triton X-100) and stored at $-70^{\circ} \mathrm{C}$. A total of 489 blood specimens was collected from the patients.

Cell culture (DEAFF and CPE), pp65 antigenemia, serology lanti-HCMV IgG and IgM (Abbott Laboratories, Abbott Park, IL)] and the pp67 NASBA assay were performed as described previously (1). The IE NASBA procedure was carried out essentially as described for the pp67 NASBA assay. Briefly, the assay was performed on a 1-ml aliquot of lysed blood suspension ( $100 \mu \mathrm{l}$ of whole blood added to $900 \mu \mathrm{l}$ of NASBA lysis buffer). Nucleic acids were isolated using the method described by Boom et al. (2). System control (SC) RNA was added to the sample prior to isolation and subsequently served as a positive control for isolation, amplification and detection. The SC RNA comprised part of the IE1 mRNA corresponding to the positions 171,797 to 172,050 of the HCMV (AD169) genome (3). SC RNA could be distinguished from WT RNA by insertion of a fragment of 134 nucleotides between nucleotides 172,028 and 172,050. This fragment originates from the $5^{\prime}$ noncoding region of the human immunodeficiency virus-type 1 pv22 sequence (5). IE WT and SC mRNA were amplified using a T7 promoter containing primer and a reverse primer. Amplification products were detected by electrochemiluminescense, using capture probes coupled to magnetic beads and WT and SC specific tris-[2,2-bipyridine]-ruthenium[II] complex-labeled oligonucleotide probes. 


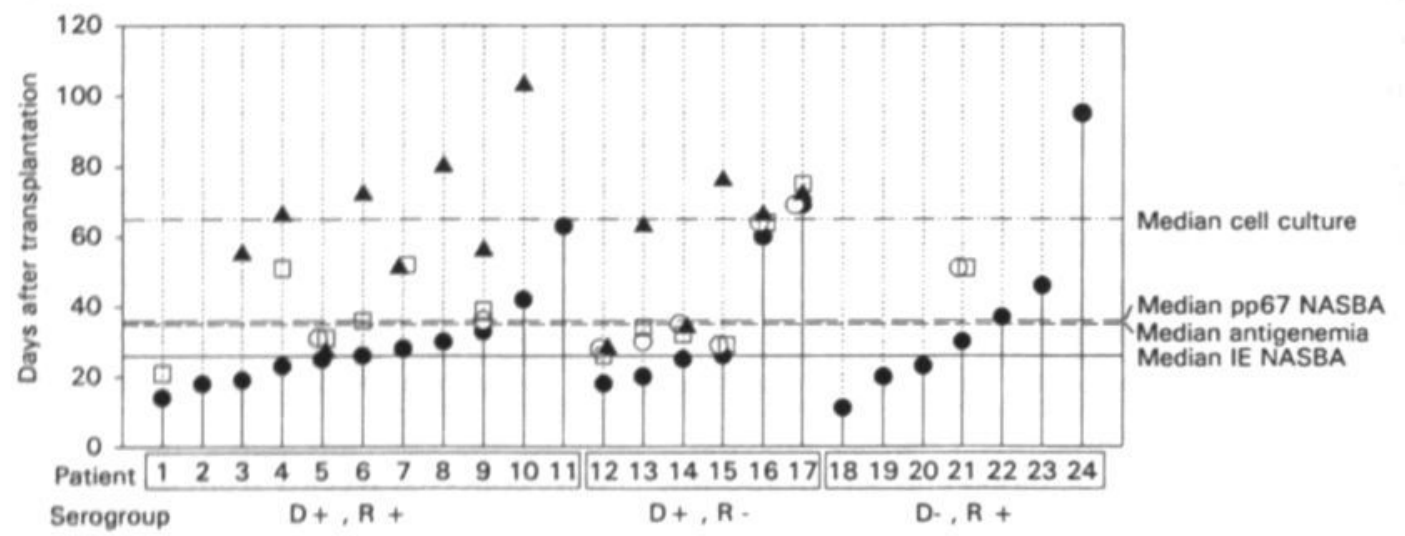

$\begin{array}{llll}- & \text { First IE NASBA positive result } & 0 & \text { First pp67 NASBA positive result } \\ - & \text { First antigenemia positive result } & \text { A } & \text { First cell culture positive result }\end{array}$

FIG. 1. Time point at which active CMV infection was detected for the first time after transplantation by the pp65 antigenemia assay, cell culture, IE and pp67 NASBA. DEAFF and CPE results were combined to give a single outcome for cell culture. The assay results are clustered for the different serogroups ICMV serostatus donor positive or negative ( $D+$ or $D-), C M V$ serostatus recipient positive or negative $(R+$ or $R-)]$. For patients $2,11,18,19,20,22,23$, and 24 the specificity of the IE NASBA results was confirmed by seroconversion of $\lg M$ and/or a significant rise of the $\lg G$ titer. This is shown in more detail for patient 19 in Figure 2 (patient I).

\section{RESULTS AND DISCUSSION}

Early detection of CMV enables the clinician to take adequate measures to prevent CMV disease. Figure 1 shows for each individual patient with CMV infection (see definition described above) at which time-point after transplantation, CMV was detected for the first time. This demonstrates that in each serogroup, IE NASBA detected CMV (median: 26 days after transplantation; range 11-95 days) before the antigenemia (median: 35; range 28-69), pp67 NASBA (median: 36; range 21-75) or cell culture assay (median: 65; range 27-103) was also found positive. In most cases, cell culture results were obtained several weeks after IE-, pp67 NASBA and antigenemia were found positive for the first time, except in four patients with a primary infection (patients 12,14, 16 and 17) and one with a secondary infection (patient 5).

Table 1 shows the incidence of active CMV infection per serogroup. In addition, the sensitivity and specificity for active CMV infection of cell culture, antigenemia assay, IEand pp67 NASBA are indicated. CMV was not detected in the group of seronegative patients who received a kidney from a seronegative donor (D-, R-). CMV infections were 
TABLE 1. The sensitivity and specificity of the pp65 antigenemia assay, cell culture a, IE-and pp67 NASBA assay for $\mathrm{CMV}$ infection ${ }^{b}$ in the different serogroups

\begin{tabular}{|c|c|c|c|c|c|c|c|c|c|c|}
\hline \multicolumn{2}{|c|}{ Serostatus } & \multirow{4}{*}{$\begin{array}{l}\text { Incidence } \\
\text { CMV } \\
\text { infection }\end{array}$} & \multicolumn{8}{|c|}{ Diagnostic values } \\
\hline \multirow{3}{*}{ Donor } & \multirow{3}{*}{ Recipient } & & \multicolumn{4}{|c|}{ Sensitivity } & \multicolumn{4}{|c|}{ Specificity } \\
\hline & & & \multicolumn{2}{|c|}{ NASBA } & \multirow{2}{*}{$\begin{array}{l}\text { Cell } \\
\text { culture }\end{array}$} & \multirow{2}{*}{$\begin{array}{c}\text { Pp65 } \\
\text { anti- } \\
\text { genemia }\end{array}$} & \multicolumn{2}{|c|}{ NASBA } & \multirow{2}{*}{$\begin{array}{l}\text { Cell } \\
\text { culture }\end{array}$} & \multirow{2}{*}{$\begin{array}{c}\text { Pp65 } \\
\text { anti- } \\
\text { genemia }\end{array}$} \\
\hline & & & IE & pp67 & & & IE & pp67 & & \\
\hline+ & + & $\begin{array}{c}85 \%^{6} \\
(11 / 13)\end{array}$ & $100 \%$ & $55 \%$ & $73 \%$ & $18 \%$ & $100 \%$ & $100 \%$ & $100 \%$ & $100 \%$ \\
\hline+ & - & $\begin{array}{l}75 \% d \\
(6 / 8)\end{array}$ & $100 \%$ & $100 \%$ & $100 \%$ & $100 \%$ & $100 \%$ & $100 \%$ & $50 \%$ & $100 \%$ \\
\hline - & + & $\begin{array}{c}69 \% \\
(9 / 13)\end{array}$ & $78 \%$ & $11 \%$ & $0 \%$ & $11 \%$ & $50 \%$ & $100 \%$ & $100 \%$ & $100 \%$ \\
\hline - & - & $0 \%$ & - & - & - & - & - & - & - & - \\
\hline
\end{tabular}

a DEAFF and CPE results were combined to give a single outcome for cell culture.

$b C M V$ infection was defined as described in the text, and served as the gold standard.

$c$ One patient developed CMV disease.

$d$ Three patients developed CMV disease.

most frequent $(85 \%)$ in the serogroup in which both donor and recipient were seropositive $(\mathrm{D}+, \mathrm{R}+)$. The sensitivity value of IE NASBA for these infections was $100 \%$, in contrast to $73 \%$ and $55 \%$ for cell culture and pp67 NASBA, respectively. The sensitivity of the antigenemia assay was as low as $18 \%$. For two patients ( 2 and 11 ), CMV infection was detected by IE NASBA, whereas pp67 NASBA, antigenemia and cell culture assay results were negative. However, in these two patients a significant rise of anti-CMV IgG titers and seroconversion of anti-CMV IgM indicated CMV infection (results not shown). This demonstrates that the IE NASBA positive results were specific. This can also be seen for the detection of reactivating CMV by IE NASBA in the group of seropositive patients who received a kidney from a seronegative donor ( $D-, R+)$. CMV infection occurred in 9 of the 13 patients $(69 \%)$. The IE NASBA assay detected $78 \%$ of the CMV infections in this patient group. Again serology confirmed CMV infection, whereas the antigenemia and pp67 NASBA assays were negative, except for patient 21. For two other patients of the same serogroup, IE mRNA was detected in several subsequent samples, whereas all other assays remained negative, including serology. For IE NASBA, this results in a specificity of $50 \%$ for the detection of infections caused by reactivating endogenous virus, since the assays that are considered as the gold standard (see definition of CMV infection) were negative.

One of the 20 patients with a secondary infection developed CMV disease. In contrast, three of the six patients with a primary CMV infection suffered from CMV disease. Although 

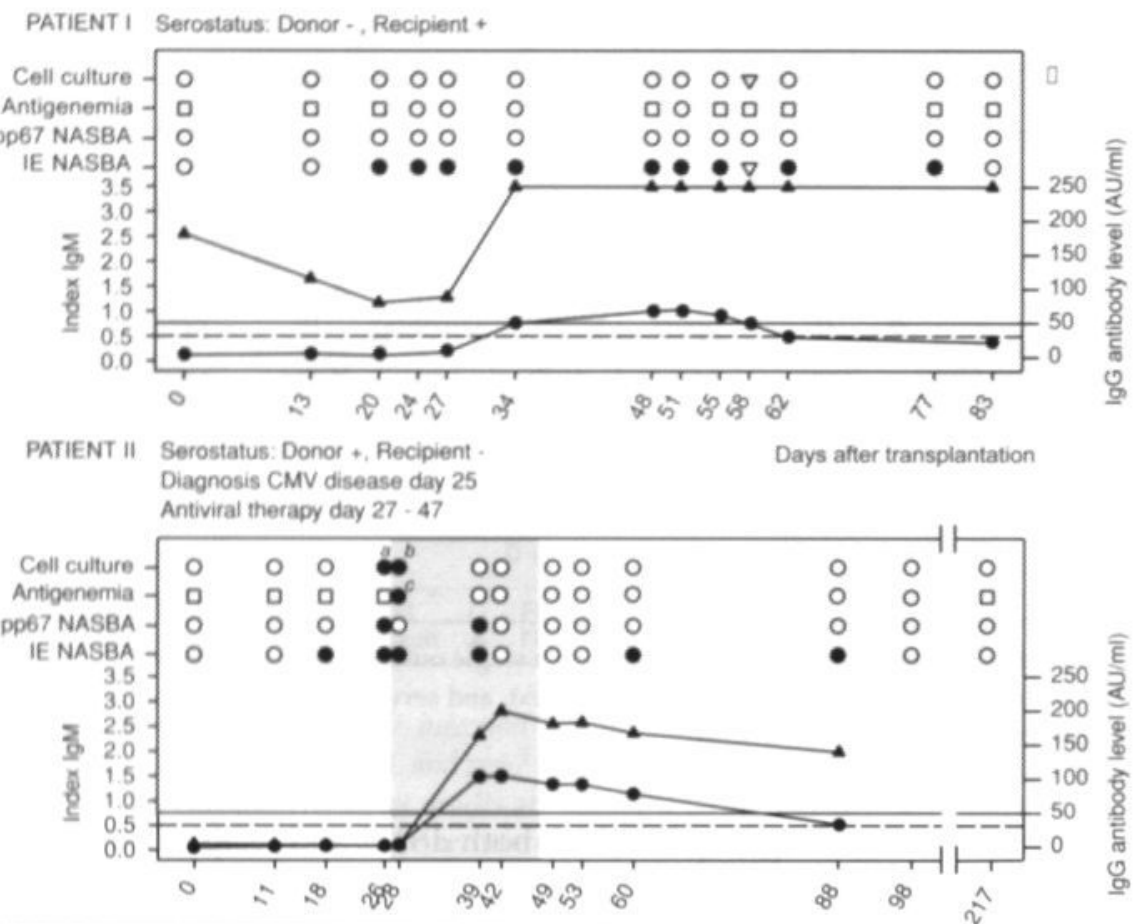

\begin{tabular}{|c|c|c|c|c|c|}
\hline$\bullet$ & Positive & $\nabla$ & Invalid & $\rightarrow \lg M$ & -- - Cut-oft lgM \\
\hline 0 & Negative & 口 & Not tested & $\multimap \lg G$ & $\longrightarrow$ Cut-off lgG \\
\hline
\end{tabular}

Days after transplantation

FIG. 2. Typical examples of results obtained by the pp65 antigenemia assay, cell culture, serology, IE- and pp67 NASBA. Patient I and II belong to the serogroup $D_{-}, R+$ and $D_{+}, R-$, respectively. The cell culture results are presented by the day the blood sample was taken from the patient (DEAFF and CPE results were combined to give a single outcome for cell culture). The gray area indicates the period of antiviral therapy. ${ }^{a}$ Result reported to the clinic at day $28 ;{ }^{b}$ result reported to the clinic at day $30 ;{ }^{c} 1$ pp65 positive cell per $50 \times 10^{3}$ leukocytes.

the primary infections were detected by all CMV detection assays used in this study, IE NASBA always detected the onset of CMV infection first.

Figure 2 shows typical results for patients from two of the four patient groups. Patient I was seropositive before transplantation, whereas the kidney donor was seronegative. These results are an example of CMV infection caused by reactivation of endogenous virus. It is likely that the IE NASBA positive results for the subsequent samples from day 20 to 77 , represent true reactivation of the virus, because anti-CMV IgG and IgM levels increased during this period. The other patient (II) suffered from a primary infection that resulted in the appearance of clinical symptoms of CMV disease at day 25. The onset of CMV infection in this patient was first detected by IE NASBA at day 18 , followed by pp67 NASBA at day 
26 and the antigenemia assay at day 28 . The first cell culture positive sample was taken from the patient at day 26 . However, this result was not known in the clinic before day 28 , because it took 2 days before the DEAFF procedure could be performed. Ganciclovir was administered to the patient from day 27 to 47 . During antiviral therapy all assays became negative. Interestingly, IE NASBA results became positive again for patient II after the therapy had stopped, at days 60 and 88 . These results probably reflect residual viral activity that was not cleared by the antiviral therapy but was controlled by improved immune reactivity, reflected by an increase in antibody titers, preventing lytic virus replication.

The IE NASBA assay proved to be a highly sensitive method for the detection of both primary and secondary CMV infections after kidney transplantation. IE NASBA indicated CMV infection significantly earlier than the other assays. This would enable the start of effective antiviral therapy at an early state of infection for the prevention of CMV disease in patients at risk, i.e. patients with a primary $\mathrm{CMV}$ infection and patients under rejection therapy. Further research needs to be done to evaluate the diagnostic value of IE NASBA for other organ transplant patients, such as bone marrow or liver transplant patients, in which CMV infection often causes disease.

\section{ACKNOWLEDGMENTS}

The authors thank Kees Vink for reading the manuscript critically and helpful discussions and Bieke Vanherle and Nicole Tacken for their help with the NASBA assays. 


\section{REFERENCES}

1. Blok, M. J., V. J. Goossens, S. J. V. Vanherle, B. Top, N. Tacken, J. M. Middeldorp, M. H. L. Christiaans, J. P. van Hooff, and C. A. Bruggeman. 1998. Diagnostic value of monitoring human cytomegalovirus late pp67 mRNA expression in renal-allograft recipients by nucleic acid sequence-based amplification. J. Clin. Microbiol. 36: 1341-1346.

2. Boom, R., C. J. A. Sol, M. M. M. Salimans, C. L. Jansen, P. M. E. Wertheim-van Dillen, and J. van der Noordaa. 1990. Rapid and simple method for purification of nucleic acids. J. Clin. Microbiol. 28:495-503.

3. Chee, M.S., A. T. Bankier, S. Beck, R. Bohni, C. M. Brown, R. Cerny, T. Horsnell, C. A. Hutchison, T. Kouzarides, J. A. Martignetti, E. Preddie, S. C. Satchwell, P. Tomlinson, K. M. Weston, and B. G. Barrell. 1990. Analysis of the protein-coding content of the sequence of human cytomegalovirus strain AD169. Curr. Top. Microbiol. Immunol. 154: 125-169.

4. Metselaar, H.J. 1990. Diagnosis and prevention of cytomegalovirus infection after organ transplantation. Ph.D. thesis, University of Rotterdam, Rotterdam, The Netherlands.

5. Muesing, M. A., D. H. Smith, C. D. Cabradilla, C. V. Benton, L. A. Lasky, and D. J. Capon. 1995. Nucleic acid structure and expression of the human AIDS/lymphadenopathy retrovirus. Nature (London) 313:450-458.

6. Stenberg, R.M., D. R.Thomsen, M. F. Stinski. 1984. Structural analysis of the major immediate early gene of human cytomegalovirus. J. Virol. 49: 190-199. 


\title{
Diagnostic Implications of Human
}

Cytomegalovirus Immediate Early-1 and pp67 mRNA Detection in Whole-Blood Samples from Liver Transplant Patients

Using Nucleic Acid Sequence-Based Amplification

\author{
M. J. BLOK, ${ }^{1}$ I. LAUTENSCHLAGER, ${ }^{2}$ V. J. GOOSSENS, ${ }^{1}$ \\ J. M. MIDDELDORP,${ }^{3}$ C. VINK, ${ }^{1}$ K. HÖCKERSTEDT, ${ }^{4}$ AND C. A. \\ BRUGGEMAN $^{1}$
}

Department of Medical Microbiology, University Hospital Maastricht, 6202 AZ Maastricht, ${ }^{1}$ and Department of Pathology, Free University Hospital, 1081 HV Amsterdam, ${ }^{3}$ The Netherlands, and Department of Virology ${ }^{2}$ and Transplantation and Liver Surgery Unit, ${ }^{4}$ Department of Surgery, ${ }^{4}$ University Hospital Helsinki, FIN-00130 Helsinki, Finland

Journal of Clinical Microbiology, December 2000, Vol. 38(12), p. 4485-4491 
CHAPTER 4 


\begin{abstract}
Nucleic acid sequence-based amplification (NASBA) was used for detection of the human cytomegalovirus (CMV) immediate early-1 (IE) and the late pp67 mRNA in 353 blood samples collected from 34 liver transplant patients. The diagnostic value of these assays was compared to that of the pp65 antigenemia assay. Overall, 95 and $42 \%$ of the antigenemia-positive samples were IE NASBA and pp67 NASBA positive, respectively. Although the results from pp67 NASBA and the antigenemia assay appeared to correspond poorly, a clear correlation was seen between pp67 NASBA-negative results and low numbers of pp65 antigen-positive cells. Twenty patients $(59 \%)$ were treated with ganciclovir after the diagnosis of symptomatic CMV infection. Before initiation of the antiviral therapy, the antigenemia assay detected the onset of symptomatic infection in all patients, whereas 95 and $60 \%$ of these patients were IE NASBA and pp67 NASBA positive, respectively. Although the sensitivity of IE NASBA was very high, the positive predictive value (PPV) of this assay for the onset of a symptomatic infection was only $63 \%$. The PPV of the antigenemia assay as well as pp67 NASBA was considerably higher ( 80 and $86 \%$, respectively). Thus, the detection of IE mRNA using NASBA appears to be particularly useful as a marker for early initiation of antiviral therapy in patients at high risk for the development of a symptomatic infection. Also, IE NASBA was found to be more sensitive than the antigenemia assay for monitoring CMV infection during antiviral therapy. On the contrary, pp67 NASBA did not appear to have additional diagnostic value compared to the antigenemia assay.
\end{abstract}




\section{INTRODUCTION}

Although the majority of the adult human population is seropositive for cytomegalovirus (CMV), symptomatic infections are mostly restricted to immunocompromised individuals, such as transplant recipients. Early detection of the virus is necessary to start effective antiviral treatment for the prevention of severe complications and death. The diagnostic value of monitoring the expression of viral immediate early (IE) and late (L) mRNAs in blood as markers for active CMV infection and disease has previously been evaluated in several studies using reverse transcriptase PCR (RT-PCR) $(3,7,13,17,18,21,23,24,27,29,31,38)$. However, controversial results were obtained regarding the clinical significance of the detection of IE and L mRNAs, most probably due to varying sensitivities of the different RT-PCR assays. Alternatively, nucleic acid sequence-based amplification (NASBA) has been developed for specific amplification of RNA (19). This technique has recently been adapted for the detection of CMV $(2,4,5,15)$ as well as other microorganisms (8). In previous studies we evaluated the diagnostic value of monitoring the expression of the CMV IE-1 and pp67 mRNA in peripheral blood of kidney transplant patients using NASBA $(4,5)$. The IE-1 mRNA is expressed directly after entrance of the virus into the cell (34), whereas pp67 mRNA is expressed in the late phase of the replication cycle in vitro $(9,10)$.

In this study, we present an evaluation of the diagnostic value of IE NASBA and pp67 NASBA for monitoring CMV infection in liver transplant patients. These patients are at higher risk for symptomatic CMV infection than kidney transplant patients (28). Liver transplant patients are usually in a critical clinical condition at the moment of transplantation and frequently require antirejection treatment. As a consequence, these patients are highly susceptible to infections with opportunistic pathogens, such as CMV. It is therefore essential to have a sensitive diagnostic assay that can predict the onset of symptomatic CMV infections at an early stage, such that antiviral therapy can be initiated in a timely fashion.

\section{MATERIALS AND METHODS}

Patients. The patient population consisted of 26 adult patients who received a liver allograft at the Helsinki University Hospital in the period from December 1996 to November 1997 and another 10 adult patients who received transplants during the period September to December 1998. The number of blood samples collected after transplantation was used as a selection criterion. Patients from which a minimum of five blood samples were obtained were included in this study $(n=34)$. 
As basic immunosuppression, the patients received triple-drug therapy with various combinations of steroids, azathioprine, and oral cyclosporine or tacrolimus. Acute rejections were treated with a high dose of methylprednisolone, and steroid-resistant rejections were treated with OKT3. Diagnosis of rejection was based on histological findings at biopsy (11). The patients were grouped according to the CMV serostatus (positive $[+]$ or negative $[-]$ ) of the transplant donor (D) and recipient (R), which resulted in the following serogroups: $\mathrm{D}+\mathrm{R}+(n=19), \mathrm{D}+\mathrm{R}-(n=4), \mathrm{D}-\mathrm{R}+(n=8)$, and $\mathrm{D}-\mathrm{R}-(n=2)$. There was one additional patient who was seropositive at the moment of transplantation, while the serostatus of the donor was unknown. Thus, $82 \%$ ( 28 of 34 ) of the liver transplant recipients were seropositive at the moment of transplantation.

Antiviral therapy. Symptomatic CMV infections were treated with ganciclovir (intravenously, $5 \mathrm{mg} / \mathrm{kg}$ of body weight twice daily) for at least 2 weeks. The diagnosis of symptomatic CMV infection was based on positive pp65 antigenemia assay results and clinical signs of CMV infection, mostly fever which could not be explained otherwise. Symptomatic CMV infection was also diagnosed in case of pneumonia with a CMVpositive finding from a bronchoalveolar lavage (BAL). Five patients with a relapse of $\mathrm{CMV}$ infection after former antiviral therapy were again treated with intravenous ganciclovir. Furthermore, for five patients the antiviral therapy was switched to orally administered ganciclovir, allowing the patients to be treated at home. In general, the patients received no antiviral prophylaxis. However, eight patients received ganciclovir intravenously during antirejection therapy in order to prevent CMV reactivation due to increased immunosuppression.

Blood samples. A total of 353 whole-blood samples were prospectively collected from 34 liver transplant recipients, including samples which were obtained shortly before the operation. Additional blood samples were collected at least once a week during hospitalization directly after transplantation and on all occasions when viral infection was suspected. Otherwise, blood samples were obtained monthly, or more frequently if the patients were again hospitalized.

pp65 antigenemia. The CMV pp65 antigenemia assay was performed as described previously $(36,37)$. Briefly, cytospot preparations were made with $1.5 \times 10^{5}$ dextran-isolated leukocytes per spot. The cells were subsequently fixed with a mixture of formaldehyde and NP-40. The pp 65 antigen was stained by an indirect immunoperoxidase protocol using the antibodies $\mathrm{c} 10$ and $\mathrm{c} 11$ (Biotest Pharma, Frankfurt, Germany). The results were expressed as the number of positive cells per $50 \times 10^{3}$ leukocytes. 
Shell vial culture. A modification of the rapid shell vial culture (16) was performed on BAL specimens as described previously (22). The BAL samples were collected from the patients when CMV pneumonia was suspected.

Serology. Patient sera were subjected to both the IMx CMV and AxSym CMV assays (Abbott Laboratories, North Chicago, III.) in order to detect CMV-specific immunoglobulin M (IgM) and IgG antibodies, respectively. The IgM titers were expressed as index values. Index values $\geq 0.500$ were considered positive. IgG titers were expressed as numbers of antibody units (AU) per milliliter. Sera with IgG levels of $\geq 15 \mathrm{AU} / \mathrm{ml}$ were considered positive. The detection limit of $250 \mathrm{AU} / \mathrm{ml}$ could be obtained for sera with high levels of IgG.

NASBA. The isolation of nucleic acids from blood samples and the NASBA procedure for amplification of the CMV IE and pp67 mRNA were carried out as described previously $(4,5)$. Briefly, nucleic acids were isolated according to the method of Boom et al. (6). First, $100 \mathrm{ml}$ of whole EDTA-treated blood was added to $900 \mathrm{ml}$ of NASBA lysis buffer, containing guanidine thiocyanate (Organon Teknika B.V., Boxtel, The Netherlands). The nucleic acids were subsequently bound to silica and washed with ethanol and acetone to remove residual cell debris. The nucleic acids were eluted from the silica after drying and used as input in the NASBA reaction. This isothermal amplification reaction $\left(41^{\circ} \mathrm{C}, 90 \mathrm{~min}\right)$ depends on the concerted action of three enzymes: T7 RNA polymerase, avian myeloblastosis virus reverse transcriptase, and RNase H. Different primer sets were used for the amplification of either IE mRNA (T7 primer, 5'-AATTCTAATACGACTCACTATAGGGAGACTTAATACAAGCCATCCACA-3'; primer 2, 5'-TAGATAAGGTTCATGAGCCT-3') or the pp67 mRNA (T7 primer, 5'AATTCTAATACGACTCACTATAGGGAGAGGGTCGATTCAGACTGA-3'; primer 2, 5'-CTGGAGATATATGTTGACCA-3'). The amplification products were detected using specific ruthenium-labeled probes and electrochemiluminescence. The assays included an internal control RNA, which served as a positive control for the isolation, amplification, and detection procedures.

Statistical analysis. The Student $\mathrm{t}$ test was used for statistical analysis of the correlation between NASBA results and the number of pp65 antigen-positive cells. The Wilcoxon matched-pair signed-rank test was used to compare the assays with respect to detection of CMV in time. $P$ values of $\leq 0.05$ were considered significant.

\section{RESULTS}

Interassay correlations. A total of 353 blood samples was prospectively collected from 34 liver transplant patients. The presence of CMV in these blood samples was routinely tested using the antigenemia assay. Part of the blood sample was stored at $-70^{\circ} \mathrm{C}$ in NASBA lysis buffer (Organon Teknika B.V.). Retrospectively, we used NASBA for the detection of 


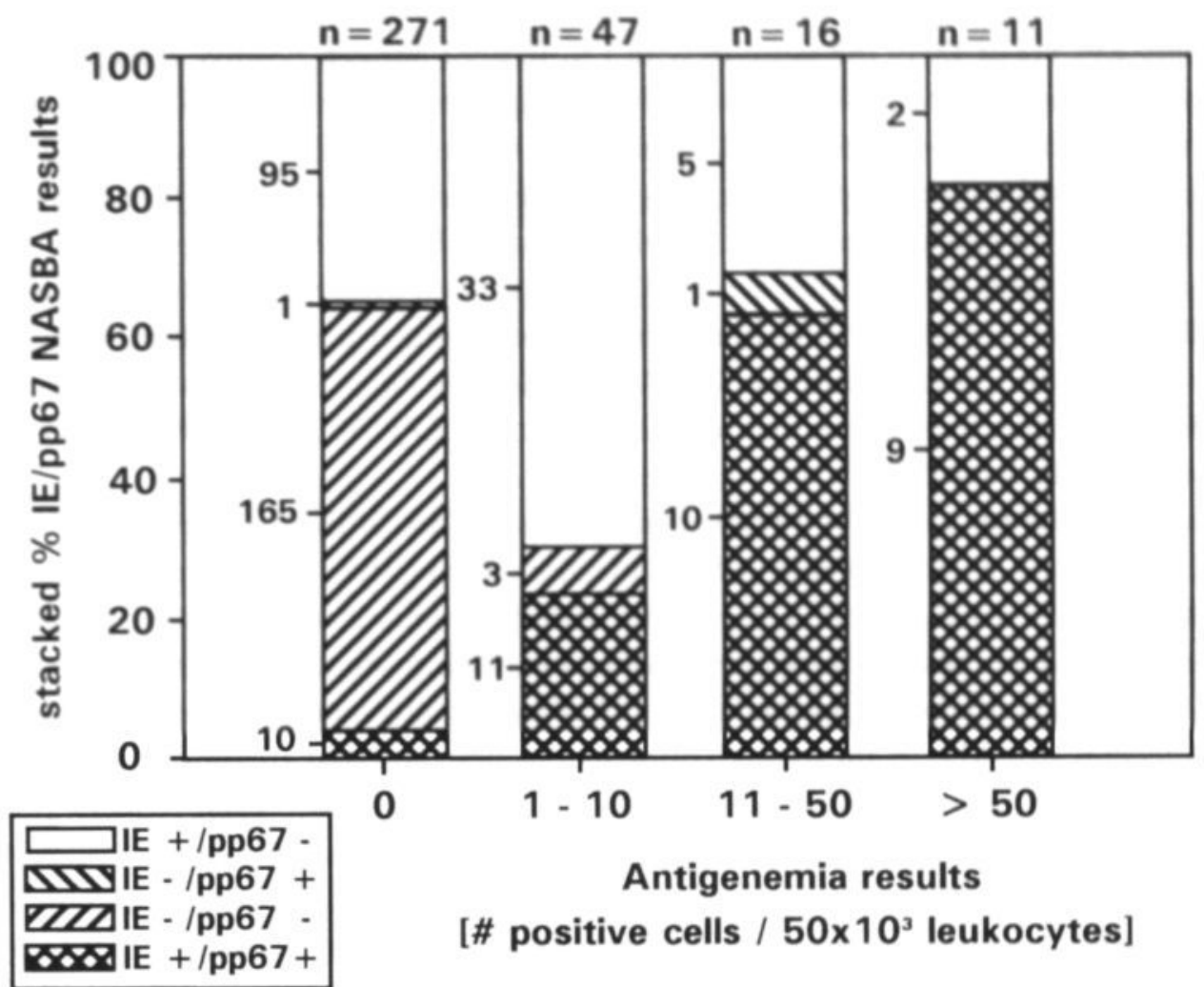

FIG. 1. Correlation between the results of the NASBA assays and the number of pp65 antigen-positive cells. The antigenemia results are divided into four groups according to the amount of pp65 antigen-positive cells/50 $\times 10^{3}$ leukocytes: 0,1 to 10,11 to 50, and $>50$. The total number of samples in each of these groups is marked above the graph. The NASBA results are also divided into four groups in which the IE NASBA and pp67 NASBA results are either positive or negative. The NASBA results are expressed as a percentage of the number of antigenemia-positive samples and are represented by a differently hatched bar. The absolute number of $N A S B A$ results is indicated on the left side of each bar.

IE mRNA and pp67 mRNA in these samples. The antigenemia and NASBA results were subsequently compared for each individual blood sample. Overall, the pp65 antigen was detected in 74 samples (21\%). IE mRNA and pp67 mRNA were detected in 175 and 42 samples (50 and $12 \%$ ), respectively. It was found that $70(95 \%)$ of the antigenemia-positive samples were also IE NASBA positive. However, $105(38 \%)$ of the IE NASBA-positive samples were antigenemia negative. Only $31(42 \%)$ of the antigenemia-positive samples were also pp67 NASBA positive. On the other hand, $11(26 \%)$ of the pp67 NASBA-positive samples were antigenemia negative. Negative pp67 NASBA results strongly correlated 
with low numbers of pp65 antigen-positive cells. This is demonstrated in Fig. 1 by the fact that only $23 \%$ ( 11 of 47 ) of the samples with 1 to 10 pp 65 antigen-positive cells per $50 \times 10^{3}$ leukocytes were pp67 NASBA positive. Of the samples with 11 to 50 pp 65 antigen-positive cells, $69 \%$ ( 11 of 16 ) were pp67 NASBA positive. A value of $82 \%$ ( 9 of 11 ) was found for the group of samples with $>50$ pp 65 antigen-positive cells. In contrast, $94 \%$ of the samples with 1 to 10 or 11 to 50 pp65 antigen-positive cells, was also IE NASBA positive ( 44 of 47 and 15 of 16 , respectively). All samples with $>50$ pp65 antigen-positive cells $(n=11)$ were IE NASBA positive. Together, the mean number of pp65 antigen-positive cells in samples that were IE NASBA positive and pp67 NASBA negative $(n=135)$ was four. This was significantly higher for samples that were both IE and pp67 NASBA positive $(n=40)$ (mean, 36 positive cells; $P<0.0001$ ).

Assay results for ganciclovir-treated infections. Of the 34 liver transplant patients, 20 (59\%) developed a symptomatic CMV infection during the follow-up (four primary infections and 16 reactivations). The patients with symptomatic infection were treated with ganciclovir. Five of these patients were given ganciclovir more than once to treat a relapse of CMV infection. In the evaluation of the NASBA and antigenemia results we focused on the detection of CMV in the period prior to the first antiviral treatment. In 17 of the symptomatic patients, the first antiviral treatment was initiated on the basis of positive antigenemia results together with clinical signs of CMV infection. For the other three patients, antiviral therapy was initiated after the diagnosis of pneumonia, with concomitant detection of CMV in a BAL sample by the shell vial assay. CMV was also present in the blood of these patients as determined by the antigenemia assay. Thus, all symptomatic infections were detected by the antigenemia assay. However, the positive predictive value (PPV) of antigenemia was $80 \%$ (20 of 25), indicating that 5 of 25 antigenemia-positive patients remained asymptomatic. IE NASBA- and pp67 NASBApositive results were obtained for $19(95 \%)$ and $12(60 \%)$ of the ganciclovir-treated patients before initiation of the first antiviral therapy. The PPV of IE NASBA was only 63\% (19 of 30 ), whereas the PPV of pp67 NASBA was $86 \%$ (12 of 14). However, IE NASBA detected the onset of CMV infection significantly earlier than both pp67 NASBA and the antigenemia assay $(P<0.001)$. No significant difference was found between the latter assays with respect to the detection of CMV in time $(P>0.05)$.

Monitoring of CMV during antiviral therapy. Blood samples were collected from patients to monitor the CMV infection during antiviral therapy. In total, 37 samples were obtained from 13 different patients (Fig. 2) during the first antiviral treatment after transplantation. This first treatment was maintained for a minimum of 2 weeks. As shown in Fig. 2, there is a clear correlation between IE NASBA- and antigenemia-positive samples 
Week $1(n=14)$

Ant.

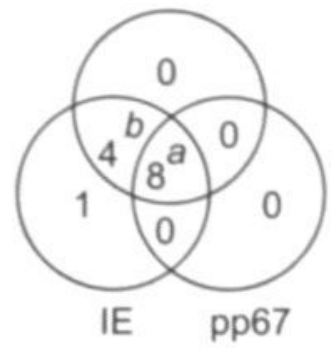

Week $2(n=10)$

Ant.

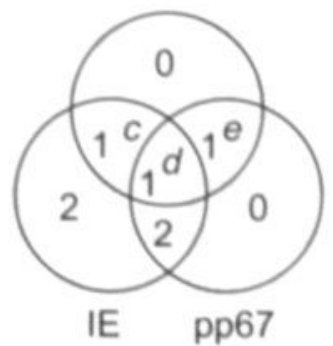

Week $3(n=3)$

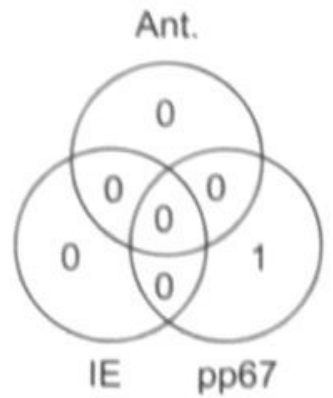

Week $4(n=3)$

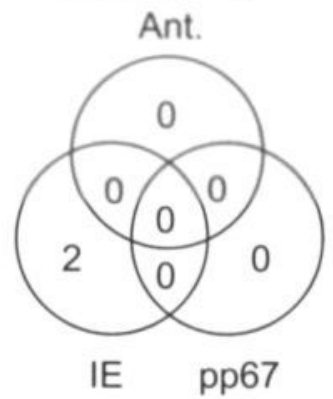

Week $>4(n=7)$

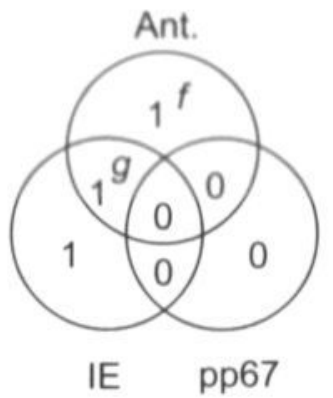

FIG. 2. Venn diagrams for antigenemia, IE, and pp67 NASBA-positive results during the first antiviral therapy after transplantation. The results are shown for 1, 2, 3, 4, and $>4$ weeks after initiation of therapy. The total number of samples that was collected from different patients in the respective weeks is indicated in parentheses. A total of 37 samples was collected from 13 different patients. Ant., antigenemia assay; IE and pp67, IE and pp67 NASBA assay, respectively. The number of pp65 antigenemia-positive cells $/ 50 \times 10^{3}$ leukocytes for each individual sample was as follows: $a: 2,10,10,50,100,100,150$, and $150 ; b: 1,2,2$, and $5 ; c: 10 ; d: 40 ; e: 30 ; f: 2 ; g: 5$.

during the first week. Furthermore, 8 of the 12 samples that were both IE NASBA and antigenemia positive were also pp67 NASBA positive. The number of antigenemia-positive cells was much higher in these samples than in samples that were only IE NASBA- and antigenemia-positive. In the second week, the number of samples that were antigenemia, IE NASBA, or pp67 NASBA positive decreased. In the third week, only one sample was pp67 NASBA positive, whereas in the fourth week only IE mRNA was detected in two samples. After more than 4 weeks of treatment, two samples were either IE NASBA positive or antigenemia positive. One sample was positive for both IE NASBA and the antigenemia assay. The antigenemia-positive samples were obtained from patients that were treated orally with ganciclovir. IE mRNA could be detected at a median of 10.5 days after the start 
of antiviral therapy (range, 0 to 63 days), whereas pp67 mRNA and pp65 antigen were detected at a median of 9 and 3.5 days (range, 0 to 17 and 0 to 63 days), respectively. Compared to the antigenemia assay, IE NASBA detected the presence of CMV significantly longer $(P<0.05)$, whereas no significant difference was found between IE NASBA and pp67 NASBA. Furthermore, there also appeared to be no significant difference between pp67 NASBA and the antigenemia assay.

Patient examples. Figure 3 shows representative examples of assay results obtained for three different liver transplant patients. Patient I suffered from a primary infection that was first detected at day 20 by IE NASBA. The pp65 antigen was detected in the subsequent sample at day 27. The pp67 NASBA test was not positive until day 38. At day 42 , symptomatic CMV infection was diagnosed and treatment with ganciclovir was initiated. Ganciclovir was given intravenously until day 51. Subsequently, the treatment was continued by oral administration until day 110, in order to prevent a recurrent CMV infection. However, during this period, positive results were again obtained for both IE NASBA and the antigenemia assay, although only few cells (two to five) were pp65 antigen positive. After antiviral therapy, IE mRNA was still detected in several samples, whereas all other assays remained negative. In the early period after transplantation, i.e., from day 27 to day 57, CMV infection was indicated by a significant rise of IgG and seroconversion of IgM. Patient I is an example of one of the four patients with a primary infection. However, the majority of the CMV infections were reactivations. In fact, $82 \%$ of the 34 patients were seropositive at the moment of transplantation. The results shown for patient II demonstrate the results for a patient with reactivating CMV. Both donor and recipient were CMV seropositive at the moment of transplantation. IE NASBA was the first assay to become positive, at day 15, followed at day 29 by both the antigenemia assay and pp67 NASBA. Then, antiviral therapy with ganciclovir was initiated and maintained for a standard period of approximately 14 days. Antiviral therapy was again initiated after the finding of an antigenemia-positive sample at day 75 . However, at this time point, no blood samples were taken that were suitable for performing NASBA assays. The antiviral treatment was continued until day 106. At day 178, the antigenemia assay was found positive, albeit at a low level. Because the patient showed no clinical symptoms of CMV infection, antiviral therapy was not initiated. The overall serological results showed a significant rise of IgG and seroconversion of IgM. Reactivation of CMV was also seen in patient III. Initially, the patient received ganciclovir prophylaxis from day 9 to 22 in order to prevent symptomatic CMV infection during antirejection therapy. Retrospectively, both IE mRNA and pp67 mRNA could be detected during that period, whereas the antigenemia assay became positive at day 26. At days 48 and 50, an increase in the number of pp65 antigen-positive 

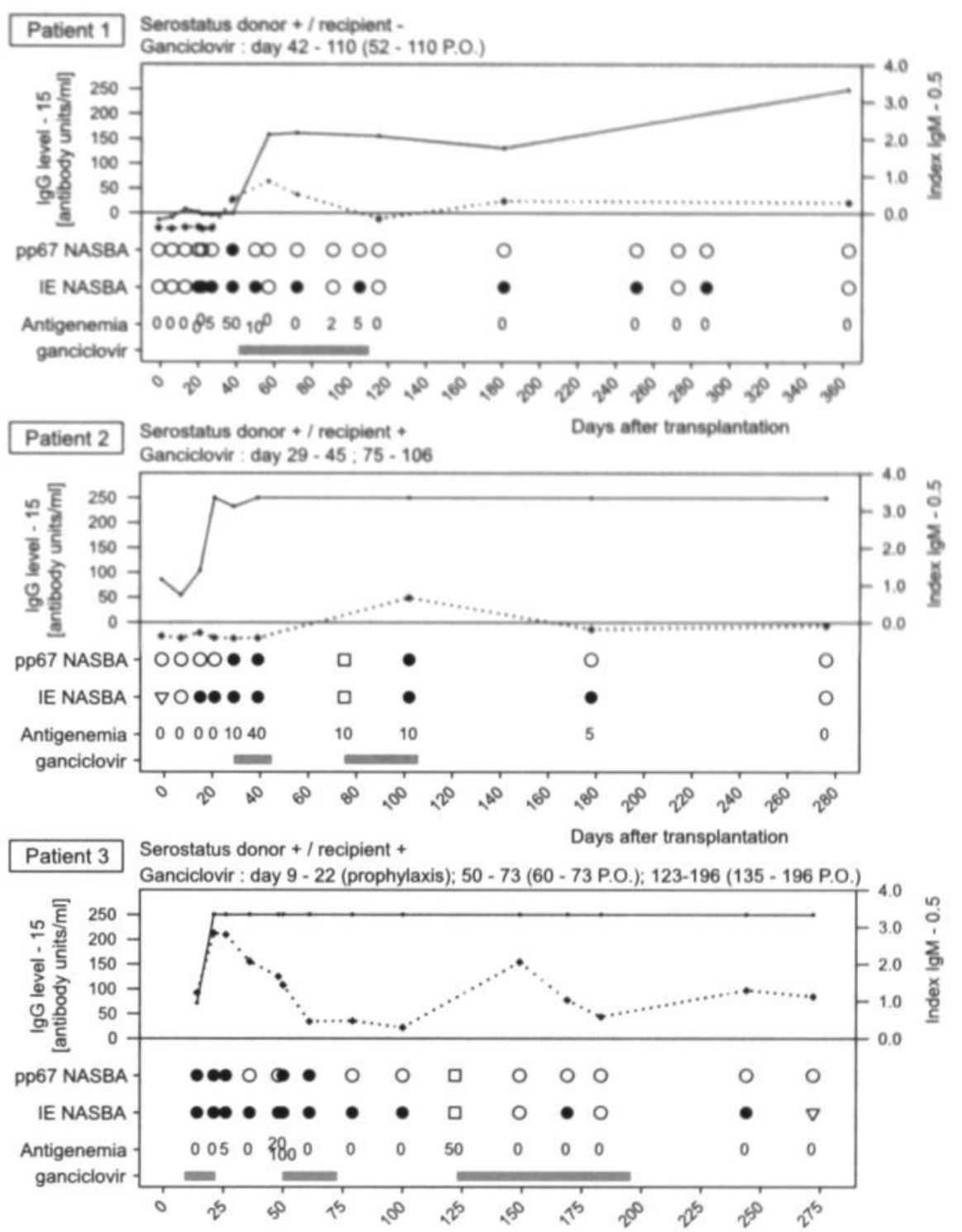

\begin{tabular}{|c|c|c|c|c|}
\hline$\bullet$ & Positive & ם & Not tested & $\because \lg G$ \\
\hline 0 & Negative & $\nabla$ & Invalid & $\cdots * \cdots \lg M$ \\
\hline
\end{tabular}

Days after transplantation

FIG. 3. Representative antigenemia, serology, and IE and pp67 NASBA assay results for three liver transplant patients. Periods of antiviral therapy with ganciclovir are indicated with grey horizontal bars. Antigenemia results are expressed as the number of positive cells $/ 50 \times 10^{3}$ leukocytes. The IgG and IgM titers are represented as the assay result minus the cutoff value (15 for IgG and 0.5 for IgM). Thus, titers above the $x$ axis are considered positive. P.O., antiviral therapy with orally administered ganciclovir. 
cells was found together with the onset of symptoms of CMV infection, which urged the start of antiviral therapy at day 50. The pp67 NASBA test was also positive at day 50 , whereas IE NASBA was positive in every subsequent sample until day 100 . At day 123 , the patient developed recurrent $\mathrm{CMV}$ infection with positive antigenemia results. Consequently, the patient was again treated with ganciclovir. NASBA results are not available for this time point. The IgG titers soon reached the detection limit of the assay ( 250 $\mathrm{AU} / \mathrm{ml}$ ), and remained high in all subsequent samples. The fluctuation of the IgM titers corresponded well with the course of infection, as indicated by the NASBA and antigenemia results.

\section{DISCUSSION}

Severe symptomatic infection after organ transplantation can be prevented by an early start of antiviral therapy with ganciclovir. The adverse effects of ganciclovir (33) and the chance of development of drug-resistant virus strains $(1,20)$ do not favor prolonged prophylactic use of this antiviral drug in every transplant recipient. Therefore, unnecessary prophylaxis in patients who are not at risk for symptomatic CMV infection should be avoided. Alternatively, preemptive therapy seems to be an effective approach to prevent the onset of a symptomatic infection $(32,33)$. This approach strongly depends on the availability of an assay which is sensitive enough to detect CMV infections before the actual onset of symptoms. Moreover, the assay should have a high predictive value for the onset of a symptomatic infection.

In this study, we investigated the diagnostic value of monitoring the expression of the CMV IE-1 and pp67 mRNA in whole-blood samples from liver transplant patients using NASBA. The results of these NASBA assays were compared to the results of the pp65 antigenemia assay. This assay is widely used for detection of CMV infections in immunocompromised patients. In general, the antigenemia assay is a sensitive assay. However, for solid-organ transplant recipients, positive antigenemia results do not always correlate with symptomatic infection (33). In this study, the initiation of antiviral therapy in liver transplant patients was guided by both positive antigenemia results and clinical signs of symptomatic CMV infection. In order to investigate the relevance of IE mRNA and pp67 mRNA detection as possible markers for early preemptive therapy, the evaluation of the NASBA results was focused on the period prior to initiation of the first antiviral treatment with ganciclovir.

Fifty-nine percent of the liver transplant patients received antiviral therapy with ganciclovir to treat symptomatic CMV infection. IE NASBA detected the onset of symptomatic CMV infection in all but one of these patients. Moreover, IE NASBA was 
positive significantly earlier than pp67 NASBA and the antigenemia assay. However, the PPV for symptomatic infection of IE NASBA was only $63 \%$. Similar findings were reported for kidney transplant recipients (4). As suggested for those patients, early detection of CMV with IE NASBA would be particularly useful for patients at high risk for a symptomatic CMV infection, e.g., patients with a primary infection or undergoing antirejection treatment. In these patients, the early detection of IE mRNA is likely to be correlated with the onset of a symptomatic infection and could possibly serve as an early marker for initiation of antiviral therapy. However, the majority of the studied population of liver transplant patients was CMV seropositive at the moment of transplantation. Therefore, most CMV infections were reactivations rather than primary infections. In addition, some of the seropositive patients were already IE NASBA positive at the moment of transplantation. This is probably due to the critical condition of most liver transplant patients, which may be accompanied by a degree of immunosuppression that allows CMV to reactivate at an early phase. Furthermore, IE mRNA could be detected in some patients after a period of antiviral treatment, although there was no relapse of a symptomatic infection (Fig. 3). Thus, the detection of IE mRNA does not necessarily predict the onset of a symptomatic infection. In contrast, it was recently reported that IE NASBA could serve as a new parameter for preemptive therapy in allogeneic bone marrow transplant recipients (14). These transplant patients are usually considered a distinct group, because mortality rates due to CMV infections in this group are higher than in other transplant patients (39, 40). Graft-versus-host disease and severe impairment in the development of specific antiviral immunity are important risk factors for development of symptomatic CMV infection in these patients $(25,26)$. Instant initiation of antiviral therapy upon the first detection of CMV after tranplantation is mandatory to prevent life-threatening disease. Therefore, early detection of the presence of CMV by monitoring the expression of IE mRNA is particularly relevant for allogeneic bone marrow transplant recipients. For kidney and liver transplant recipients, however, IE NASBA results are not sufficient for evaluation of the risk for the onset of a symptomatic infection, in particular for patients with a reactivation.

In this study, it was found that $58 \%$ (43 of 74 ) of the antigenemia-positive samples were pp67 NASBA negative. As a possible explanation for these discrepancies, we hypothesized that samples that were collected during antiviral treatment with ganciclovir are more likely to be positive by the antigenemia assay than by pp67 NASBA. Ganciclovir exerts its antiviral activity by inhibition of the viral DNA polymerase (35). This should result in a block of the synthesis of viral late transcripts, such as the pp 67 mRNA. Because, the pp 65 protein may be more stable than the pp 67 mRNA, it may still be present in the blood at time points 
at which the pp67 mRNA has already been degraded. In addition, it is possible that pp65 protein is still synthesized during ganciclovir treatment. Unlike the pp67 mRNA, the pp65 mRNA is not a true late transcript (12). Its transcription is therefore not directly affected by inhibitors of viral DNA synthesis. However, of the 43 samples that were antigenemia positive and pp67 NASBA negative, only 7 were obtained during a period of antiviral treatment with ganciclovir. In fact, for eight patients these discrepancies were found before initiation of antiviral therapy. As a consequence, the sensitivity of pp67 NASBA for the detection of a symptomatic CMV infection was low (60\%). Nevertheless, for six of these patients, the number of pp65 antigen-positive cells was low, ranging from 2 to 30 . The other two patients became pp67 NASBA positive several days after the start of antiviral treatment.

The low sensitivity of pp67 NASBA found in this study is in contrast with the previous findings reported for kidney transplant recipients (5). In these patients, pp67 mRNA could be detected in all patients with a symptomatic infection. A high sensitivity of pp67 NASBA was also reported by Gerna et al. for heart and lung transplant recipients with a reactivated $\mathrm{CMV}$ infection (15). A cutoff level of $\geq 100$ pp65 antigen-positive cells $/ 2 \times 10^{5}$ leukocytes was used for the initiation of preemptive antiviral therapy in these patients. The pp67 mRNA could be detected in all patients who were treated according to these criteria. In this study, we also found a positive correlation between the number of pp65 antigen-positive cells and the positivity of pp67 NASBA (Fig. 1). However, we did not use a cutoff level for the antigenemia assay. Instead, an antigenemia-positive sample together with clinical symptoms of CMV infection was an indication for the start of antiviral treatment of the liver transplant patients. The discrepancy between the different studies with respect to the sensitivity of pp67 NASBA is probably explained by the difference in timing of the start of antiviral therapy with ganciclovir. As explained above, ganciclovir should inhibit the synthesis of late mRNA. As a consequence, early onset of antiviral therapy could prevent the detection of pp67 mRNA. In fact, in studies in which patients were preemptively treated with ganciclovir, based on the first antigenemia-positive samples after transplantation, the sensitivity of pp67 NASBA for the detection of symptomatic CMV infection was found to be lower than the sensitivity of the antigenemia assay $(14,15,30)$. It is difficult to investigate this hypothesis because delayed initiation of antiviral therapy based on pp67 NASBA-positive results in these patients may increase the risk for the development of symptomatic infection to an unacceptable level. Nevertheless, detection of pp67 mRNA appears to have no additional diagnostic value compared to the antigenemia assay as a marker for the early start of preemptive therapy in patients at high risk for the onset of symptomatic CMV infection. 
In previous studies, no significant difference was found between the disappearance of CMV from the blood during antiviral therapy as determined by pp67 NASBA and the antigenemia assay $(5,14,15)$. A similar result was found in this study. However, it should be noted that for several patients the pp67 NASBA assay was negative before and during antiviral therapy, whereas the antigenemia assay was found to be positive. In agreement with the results described above, the pp67 NASBA-negative results obtained during antiviral therapy corresponded with low levels of pp65 antigen-positive cells. For IE NASBA, a clear correlation was found with the results of the antigenemia assay, in particular during the first week of antiviral therapy. Thereafter, IE mRNA could still be detected, whereas the antigenemia assay was negative. In addition, it was found that IE mRNA could be detected after termination of therapy (Fig. 3). Similar findings were reported for individual allogeneic bone marrow transplant recipients (14). Nevertheless, for most of these patients, the times to disappearance of CMV during antiviral therapy, as demonstrated by IE NASBA, pp67 NASBA, and the antigenemia assay, were comparable. It should be investigated in more detail whether prolonged IE mRNA detection has clinical implications. As such, this could justify prolonged antiviral treatment with ganciclovir.

In conclusion, the detection of IE mRNA appears to be particularly useful as a marker for early initiation of preemptive antiviral therapy in patients at high risk for the development of a symptomatic infection. In contrast to IE NASBA, pp67 NASBA did not appear to have additional diagnostic value compared to the antigenemia assay.

\section{ACKNOWLEDGMENTS}

We thank Bieke Vanherle, Martine Hulsbosch, Annick Hermans, and Magdalena Garcia for their help with the NASBA tests and serological assays and Raisa Loginov, Kristina Messina, and Kaarina Inkinen for performing the pp65 antigenemia assays and collecting the samples for NASBA and serology. Finally, we thank Organon Teknika B.V. for providing the NASBA reagents. 


\section{REFERENCES}

1. Alain, S., P. Honderlick, D. Grenet, M. Stern, C. Vadam, M. J. Sanson Le Pors, and M. C. Mazeron. 1997. Failure of ganciclovir treatment associated with selection of a ganciclovirresistant cytomegalovirus strain in a lung transplant recipient. Transplantation 63:1533-1536.

2. Aono, T., K. Kondo, H. Miyoshi, K. Tanaka Taya, M. Kondo, Y. Osugi, J. Hara, S. Okada, and K. Yamanishi. 1998. Monitoring of human cytomegalovirus infections in pediatric bone marrow transplant recipients by nucleic acid sequence-based amplification. J. Infect. Dis. 178:1244-1249.

3. Bitsch, A., H. Kirchner, R. Dupke, and G. Bein. 1993. Cytomegalovirus transcripts in peripheral blood leukocytes of actively infected transplant patients detected by reverse transcriptionpolymerase chain reaction. J. Infect. Dis. 167:740-743.

4. Blok, M. J., M. H. Christiaans, V. J. Goossens, J. P. van Hooff, P. Sillekens, J. M. Middeldorp, and C. A. Bruggeman. 1999. Early detection of human cytomegalovirus infection after kidney transplantation by nucleic acid sequence-based amplification. Transplantation 67:1274-1277.

5. Blok, M. J., V. J. Goossens, S. J. V. Vanherle, B. Top, N. Tacken, J. M. Middeldorp, M. H. L. Christiaans, J. P. van Hooff, and C. A. Bruggeman. 1998. Diagnostic value of monitoring human cytomegalovirus late pp67 mRNA expression in renal-allograft recipients by nucleic acid sequence-based amplification. J. Clin. Microbiol. 36:1341-1346.

6. Boom, R., C. J. A. Sol, M. M. M. Salimans, C. L. Jansen, P. M. E. Wertheim-van Dillen, and J. van der Noordaa. 1990. Rapid and simple method for purification of nucleic acids. J. Clin. Microbiol. 28:495-503.

7. Buffone, G. J., E. Hine, and G. J. Demmler. 1990. Detection of mRNA from the immediate early gene of human cytomegalovirus in infected cells by in vitro amplification. Mol. Cell. Probes 4:143-151.

8. Chan, A. B., and J. D. Fox. 1999. NASBA and other transcription-based amplification methods for research and diagnostic microbiology. Rev. Med. Microbiol. 10(4):185-196.

9. Davis, M. G., and E.-S. Huang. 1985. Nucleotide sequence of a human cytomegalovirus DNA fragment encoding a 67-kilodalton phosphorylated viral protein. J. Virol. 56:7-11.

10. Davis, M. G., E.-C. Mar, Y.-M. Wu, and E.-S. Huang. 1984. Mapping and expression of a human cytomegalovirus major viral protein. J. Virol. 52:129-135.

11. Demetris, J. A., K. P. Batts, A. P. Dhillon, L. Ferrell, J. Fung, S. A. Geller, J. Hart, P. Havry, W. J. Hofman, S. Hubscher, J. Kemnitz, G. Koukoulis, R. G. Lee, K. J. Lewin, J. Ludwig, R. S. Markin, L. M. Petrovic, M. J. Phillips, B. Portmann, J. Rakela, P. Randhawa, F. P. Reinholt, M. Reynès, M. J. Robert, H. Schlitt, K. Solez, D. Snover, E. Taskinen, S. N. Thung, G. W. Tillery, R. H. Wiesner, D. G. D. Wight, W. Williams, and H. Yamabe. 1997. Banff schema for grading liver allograft rejection: an international consensus document. Hepatology 25:658-663.

12. Depto, A. S., and R. M. Stenberg. 1989. Regulated expression of the human cytomegalovirus pp65 gene: octamer sequence in the promoter is required for activation by viral gene products. J. Virol. 63:1232-1238.

13. Gaeta, A., C. Nazzari, S. Angeletti, M. Lazzarini, E. Mazzei, and C. Mancini. 1997. Monitoring for cytomegalovirus infection in organ transplant recipients: analysis of pp65 antigen, DNA and late mRNA in peripheral blood leukocytes. J. Med. Virol. 53:189-195. 
14. Gerna, G., F. Baldanti, D. Lilleri, M. Parea, E. Alessandrino, A. Pagani, F. Locatelli, J. Middeldorp, and M. G. Revello. 2000. Human cytomegalovirus immediate-early mRNA detection by nucleic acid sequence-based amplification as a new parameter for preemptive therapy in bone marrow transplant recipients. J. Clin. Microbiol. 38:1845-1853.

15. Gerna, G., E. Baldanti, J. M. Middeldorp, M. Furione, M. Zavattoni, D. Lilleri, and M. G. Revello. 1999. Clinical significance of expression of human cytomegalovirus pp67 late transcript in heart, lung, and bone marrow trans-plant recipients as determined by nucleic acid sequencebased amplification. J. Clin. Microbiol. 37:902-911.

16. Gleaves, C. A., T. F. Smith, E. A. Shuster, and G. R. Pearson. 1984. Rapid detection of cytomegalovirus in MRC-5 cells inoculated with urine specimens by using low-speed centrifugation and monoclonal antibody to an early antigen. J. Clin. Microbiol. 19:917-919.

17. Gozlan, J., J. P. Laporte, S. Lesage, M. Labopin, A. Najman, N. C. Gorin, and J. C. Petit. 1996. Monitoring of cytomegalovirus infection and disease in bone marrow recipients by reverse transcription-PCR and comparison with PCR and blood and urine cultures. J. Clin. Microbiol. 34:2085-2088.

18. Gozlan, J., J. M. Salord, C. Chouaid, C. Duvivier, O. Picard, M. C. Meyohas, and J. C. Petit. 1993. Human cytomegalovirus (HCMV) late-mRNA detection in peripheral blood of AIDS patients: diagnostic value for HCMV disease compared with those of viral culture and HCMV DNA detection. J. Clin. Microbiol. 31:1943-1945.

19. Kievits, T., B. van Gemen, D. van Strijp, R. Schukkink, M. Dircks, H. Adriaanse, L. Malek, R. Sooknanan, and P. Lens. 1991. NASBA isothermal enzymatic in vitro nucleic acid amplification optimized for the diagnosis of HIV-1 infection. J. Virol. Methods 35:273-286.

20. Kruger, R. M., W. D. Shannon, M. Q. Arens, J. P. Lynch, G. A. Storch, and E. P. Trulock. 1999. The impact of ganciclovir-resistant cytomegalovirus infection after lung transplantation. Transplantation 68:1272-1279.

21. Lam, K. M., N. Oldenburg, M. A. Khan, V. Gaylore, G. W. Mikhail, P. D. Strouhal, J. M. Middeldorp, N. Banner, and M. Yacoub. 1998. Significance of reverse transcription polymerase chain reaction in the detection of human cytomegalovirus gene transcripts in thoracic organ transplant recipients. J. Heart Lung Transplant 17:555-565.

22. Lautenschlager, I., J. Suni, J. Ahonen, C. Gronhagen Riska, P. Ruutu, T. Ruutu, and P. Tukiainen. 1989. Detection of cytomegalovirus by the early-antigen immunofluorescence test versus conventional tissue culture. Eur. J. Clin. Microbiol. Infect. Dis. 8:610-613.

23. Meyer, T., U. Reischl, H. Wolf, C. Schuller, and R. Arndt. 1994. Identification of active cytomegalovirus infection by analysis of immediate-early, early and late transcripts in peripheral blood cells of immunodeficient patients. Mol. Cell. Probes 8:261-271.

24. Meyer-König, U., A. Serr, D. von Laer, G. Kirste, C. Wolff, O. Haller, D. Neumann Haefelin, and F. T. Hufert. 1995. Human cytomegalovirus immediate early and late transcripts in peripheral blood leukocytes: diagnostic value in renal transplant recipients. J. Infect. Dis. 171:705-709.

25. Meyers, J. D., N. Flournoy, and E. D. Thomas. 1986. Risk factors for cytomegalovirus infection after human marrow transplantation. J. Infect. Dis. 153:478-488. 
26. Muller, C. A., H. Hebart, A. Roos, H. Roos, M. Steidle, and H. Einsele. 1995. Correlation of interstitial pneumonia with human cytomegalovirus-induced lung infection and graft-versushost disease after bone marrow transplantation. Med. Microbiol. Immunol. Berl. 184:115-121.

27. Nelson, P. N., B. K. Rawal, Y. S. Boriskin, K. E. Mathers, R. L. Powles, H. M. Steel, Y. S. Tryhorn, P. D. Butcher, and J. C. Booth. 1996. A polymerase chain reaction to detect a spliced late transcript of human cytomegalovirus in the blood of bone marrow transplant recipients. J. Virol. Methods 56:139-148.

28. Patel, R., and C. V. Paya. 1997. Infections in solid-organ transplant recipients. Clin. Microbiol. Rev. 10:86-124.

29. Patel, R., T. F. Smith, M. Espy, D. Portela, R. H. Wiesner, R. A. Krom, and C. V. Paya. 1995. A prospective comparison of molecular diagnostic techniques for the early detection of cytomegalovirus in liver transplant recipients. J. Infect. Dis. 171:1010-1014.

30. Pellegrin, I., I. Garrigue, D. Ekouevi, L. Couzi, P. Merville, P. Merel, G. Chene, M. H. Schrive, P. Trimoulet, M. E. Lafon, and H. Fleury. 2000. New molecular assays to predict occurrence of cytomegalovirus disease in renal transplant recipients. J. Infect. Dis. 182:36-42.

31. Randhawa, P. S., R. Manez, B. Frye, and G. D. Ehrlich. 1994. Circulating immediate-early mRNA in patients with cytomegalovirus infections after solid organ transplantation. J. Infect. Dis. 170:1264-1267.

32. Rubin, R. H. 1991. Preemptive therapy in immunocompromised hosts. N. Engl. J. Med. 324:1057-1059.

33. Sia, I. G., and R. Patel. 2000. New strategies for prevention and therapy of cytomegalovirus infection and disease in solid-organ transplant recipients. Clin. Microbiol. Rev. 13:83-121.

34. Stenberg, R. M., D. R. Thomsen, and M. F. Stinski. 1984. Structural analysis of the major immediate early gene of human cytomegalovirus. J. Virol. 49:190-199.

35. Swierkosz, E. M., and R. L. Hodinka. 1999. Antiviral agents and susceptibility tests, p. 1624-1639. In P. R. Murray, E. J. Baron, M. A. Pfaller, F. C. Tenover, and R. H. Yolken (ed.), Manual of clinical microbiology, 7th ed. American Society for Microbiology, Washington, D.C.

36. The, T. H., A. P. van den Berg, M. C. Harmsen, W. Van der Bij, and W. J. van Son. 1995. The cytomegalovirus antigenemia assay: a plea for standardization. Scand. J. Infect. Dis. 99(Suppl.):25-29.

37. Van der Bij, W., J. Schirm, R. Torensma, W. J. van Son, A. M. Tegzess, and T. H. The. 1988. Comparison between viremia and antigenemia for detection of cytomegalovirus in blood. J. Clin. Microbiol. 26:2531-2535.

38. Velzing, J., P. H. Rothbarth, A. C. Kroes, and W. G. Quint. 1994. Detection of cytomegalovirus mRNA and DNA encoding the immediate early gene in peripheral blood leukocytes from immunocompromised patients. J. Med. Virol. 42:164-169.

39. Wingard, J. R., S. Piantadosi, W. H. Burns, M. L. Zahurak, G. W. Santos, and R. Saral. 1990. Cytomegalovirus infections in bone marrow transplant recipients given intensive cytoreductive therapy. Rev. Infect. Dis. 12(Suppl. 7):S793-804.

40. Winston, D. J., W. G. Ho, and R. E. Champlin. 1990. Cytomegalovirus infections after allogeneic bone marrow transplantation. Rev. Infect. Dis. 12 (Suppl. 7):S776-792. 


\section{Immediate Early-1 mRNA Expression and Virus Production are Restricted During the Acute Phase of Rat Cytomegalovirus Infection in Immunocompetent Rats}

MARINUS J. BLOK, KIM G. M. SAVELKOULS, GERT E. L. M. GRAULS, CATHRIEN A. BRUGGEMAN AND CORNELIS VINK

Department of Medical Microbiology, Cardiovascular Research Institute Maastricht, Maastricht University, 6202 AZ Maastricht, The Netherlands

A modified version of this chapter is submitted to Virology 
CHAPTER 5 


\begin{abstract}
We characterized the dissemination of rat cytomegalovirus (RCMV) after primary infection of immunocompetent rats. The presence of infectious virus, viral DNA and mRNA (immediate-early R123 [IE-1], early R44 and late R32 transcripts) in different organs was determined at defined time-points post infection (pi). During the first week pi, RCMV DNA could be detected in virtually every organ. In addition, late and/or early mRNA was found in several organs and tissues, such as salivary glands, spleen, liver, lungs, heart, brain, bone marrow and blood leukocytes. However, infectious virus and IE-1 mRNA were rarely detected. Together, these results indicated that the replication of RCMV in immunocompetent rats is severely restricted compared to that in immunocompromised rats during the first week pi. At 4 months pi, infectious virus, viral DNA and each of the three viral transcripts were detected in the salivary glands of the majority of the rats. In the other organs, RCMV DNA was found occasionally, but neither infectious virus nor any of the viral transcripts were detected in these organs. Interestingly, we identified two novel antisense transcripts from the major IE region that are partly complementary to the IE-1 transcript. These antisense transcripts, IE-AS1 and IE-AS2, were detected in blood leukocytes in the absence of IE-1 mRNA expression. However, IE-1 and IE-AS mRNA were found to be expressed simultaneously in the salivary glands and in RCMV-infected fibroblasts in vitro. Although the function of the RCMV IE-AS transcripts is still enigmatic, their expression adds yet another intriguing feature to the compact and complex pattern of herpesviral gene expression.
\end{abstract}




\section{INTRODUCTION}

Human cytomegalovirus (HCMV) is an important cause of morbidity and mortality in immunocompromised patients, such as organ transplant recipients and individuals with AIDS $(30,47)$. In our laboratory, rat cytomegalovirus (RCMV) is being studied as a model for HCMV. Like HCMV infections, RCMV infections of immunocompetent hosts are usually not life-threatening even when a high dose of virus is used $(10,11,55)$. In contrast, RCMV infection of immunocompromised rats results in severe complications and high mortality rates (55). During the first week after primary infection of immunocompetent rats with RCMV, infectious virus can be isolated from several organs, except the salivary glands $(11,55)$. In general, infectious virus cannot be isolated from the salivary glands within 10 days post infection (pi), although RCMV DNA can be detected in these glands as early as 3 days pi (7). Up to 28 days pi, virus titers increase in the salivary glands, whereas infectious virus can no longer be detected in other organs. However, it is likely that RCMV is still present in these organs in a latent form, since studies in which latently infected renal allografts were transplanted to seronegative rats indicated that virus could reactivate although infectious virus could not be isolated from this organ (13, 15). Similar findings were reported with cardiac allografts, although virus reactivated less frequently from these allografts than from renal allografts (13). RCMV could also be isolated from latently infected spleens by long-term cocultivation with rat embryonic fibroblasts (REF) (10). In contrast, transfer of latent virus could not be accomplished by means of syngeneic or allogeneic transfusion of peripheral blood leukocytes (PBL) or thoracic duct cells into immunocompromised hosts (13).

In the majority of the previous studies on RCMV infections in vivo, rats were subjected to immune suppression prior to virus administration. This allowed the virus to replicate efficiently and induce a full-blown, severe infection (55). Nevertheless, natural CMV infections generally occur in immunocompetent hosts, which usually do not suffer from serious complications due to the infection. Despite the stringent control of the infection, however, the virus is still able to establish a life-long, latent infection in these hosts.

In order to study the pathogenesis of RCMV infection, virus dissemination as well as viral gene expression under 'natural' conditions in vivo, we set out to monitor the course of RCMV infection of immunocompetent rats at various time points pi. To this end, organs and tissues of rats were subjected to different (RT-) PCR assays, which allow the highly sensitive detection of RCMV genomic DNA as well as transcripts. Previously, we developed a nested PCR that enables the reliable detection of approximately 10 copies of viral DNA (6). Here, we describe the generation of three novel RT-PCR assays that monitor the expression of genes that are transcribed during different phases of RCMV infection in 
vitro. These genes include R32, a late gene that encodes the homolog of the HCMV major tegument protein $(8,61)$, R44, an early-late gene that encodes the homolog of the HCMV DNA polymerase accessory protein $(31,61)$, and R123, an immediate early (IE) gene encoding the homolog of the HCMV major IE-1 protein (5). By using the PCR and RT-PCR assays, we demonstrate that RCMV DNA is present in many organs during the acute phase of infection in immunocompetent rats. Although early and late mRNA were found in several of these organs at 7 days pi, infectious virus was not detected at that time-point. Interestingly, expression of IE-1 mRNA was only rarely observed. After 4 months, infectious virus, viral DNA and mRNAs were found to be present in the salivary glands. In the other organs, RCMV DNA was occasionally detected, but not viral mRNA or infectious virus. Finally, we describe the identification of two novel, antisense transcripts from the RCMV major IE (MIE) region. These mRNAs could be detected in PBL and salivary glands at 7 days pi, in salivary glands at 120 days pi, and in vitro, in productively infected REF.

\section{MATERIALS AND METHODS}

Rats and virus. Three-week-old male specific-pathogen-free Wistar Kyoto rats (Central Animal Facility, Maastricht University, Maastricht, the Netherlands) were infected with $1 \mathrm{x}$ $10^{5}$ PFU of RCMV (Maastricht strain). In an initial experiment (experiment I), 30 rats were infected of which 5 were sacrificed at either 3,5, 7, 14, 31 or 120 days pi. Salivary glands, spleen, kidney, liver, lungs, heart, thymus, pancreas, brain, aorta, left carotid artery, PBL, blood plasma, and bone marrow were collected and stored immediately at $-70^{\circ} \mathrm{C}$ until nucleic acid isolation or plaque assay analysis. In this experiment, nucleic acid isolates of the organs were analyzed for the presence of RCMV DNA using PCR (see below). The plaque assay was performed as described previously (12). Virus titers were expressed as PFU per $\mathrm{ml}$ of a $10 \% \mathrm{w} / \mathrm{v}$ organ suspension.

In a second experiment (experiment II), a group of 10 three-week-old rats were infected with $1 \times 10^{5}$ PFU of RCMV. Five rats were sacrificed at either 7 or 120 days pi, respectively, and a similar set of organs and tissues as described above was collected from these animals. From these organs, nucleic acids were isolated and analyzed for the presence of both genomic RCMV DNA and mRNA using PCR and RT-PCR, respectively (see below). In addition, plaque assay was performed for salivary glands, spleen and liver.

In vitro RCMV infection of REF cells. REF cells were grown in EMEM supplemented with $10 \%$ NCS until confluency. The cells were subsequently incubated with RCMV at a multiplicity of infection of 1 in EMEM supplemented with $2 \%$ NCS for 1 hour. Thereafter, the medium was replaced with fresh EMEM supplemented with $2 \%$ NCS. After 48 hours, 
the cells were collected using a cell-scraper and centrifuged at $725 \times \mathrm{g}$ for $10 \mathrm{~min}$ at $4^{\circ} \mathrm{C}$. A total of $3 \times 10^{6}$ cells was used for isolation of total nucleic acids.

Blood plasma preparation and isolation of PBL. EDTA-blood was collected from the rats by puncture of the abdominal aorta. The blood samples were centrifuged at 1,250 $\mathrm{g}$ for $10 \mathrm{~min}$ at $4^{\circ} \mathrm{C}$. Hundred $\mu \mathrm{l}$ of plasma was collected and stored at $-70^{\circ} \mathrm{C}$ until nucleic acid isolation. The layer of buffy coat cells was subsequently aspirated and transferred to a new tube. Contaminating erythrocytes were lysed for $10 \mathrm{~min}$ at $4^{\circ} \mathrm{C}$ in a buffer containing 0.155 $\mathrm{M} \mathrm{NH}_{4} \mathrm{Cl}, 0.01 \mathrm{M} \mathrm{KHCO}_{3}$ and $0.1 \mathrm{mM}$ EDTA. The leukocytes were centrifuged at $725 \times \mathrm{g}$ for $10 \mathrm{~min}$ at $4^{\circ} \mathrm{C}$ and washed three times with PBS. After the final wash step, $0.5 \times 10^{7}$ to $1.0 \times 10^{7}$ cells were stored at $-70^{\circ} \mathrm{C}$ until nucleic acid isolation. In addition, $0.5 \times 10^{6}$ to $1.0 \times 10^{6}$ cells were resuspended in $1 \mathrm{ml}$ of EMEM supplemented with $2 \% \mathrm{NCS}$ and kept at $-70^{\circ} \mathrm{C}$ until plaque titration.

Preparation of bone marrow samples. Bone marrow cells were extracted from both femurs of a rat and subsequently washed three times with PBS. A total of $1.5 \times 10^{7}$ cells was resuspended in $1 \mathrm{ml}$ EMEM supplemented with $2 \%$ NCS for plaque titration. In addition, $1 \times 10^{7}$ cells were used for isolation of nucleic acids.

Isolation of DNA and RNA. The XTRAX DNA isolation kit (Gull Laboratories, Salt Lake City, Utah) was used for the isolation of total cellular DNA. Extractions were performed according to the manufacturer with some technical modifications. Briefly, various tissue samples (50 - $200 \mathrm{mg}$ ), bone marrow, blood cells and plasma were resuspended in $1 \mathrm{ml}$ of lysis buffer and lysed during rotation for at least 3 hours. A water sample was included after every ninth organ sample to serve as a negative control for cross-contamination during the isolation procedure. The samples were centrifuged at $20,000 \times \mathrm{g}$ for $1 \mathrm{~min}$ and $800 \mu \mathrm{l}$ of the supernatant was transferred to a new reaction tube. Proteins were subsequently denatured by heating the samples to $95^{\circ} \mathrm{C}$ for $5 \mathrm{~min}$, followed by cooling at room temperature. After another round of heating and cooling, the samples were centrifuged for $2 \mathrm{~min}$ at $20,000 \mathrm{xg}$. Five hundred $\mu \mathrm{l}$ of the supernatant was transferred to a new reaction tube and an equal volume of isopropanol was added. The nucleic acids were precipitated during $5 \mathrm{~min}$ at room temperature. After centrifugation at $20,000 \times \mathrm{g}$ for $2 \mathrm{~min}$, the pellet was washed with $70 \% \mathrm{EtOH}$, air-dried and dissolved in $35 \mu \mathrm{l}$ of $\mathrm{H}_{2} \mathrm{O}$. The nucleic acid concentration was determined by measuring the optical density (OD) at $260 \mathrm{~nm}$ in a spectrophotometer.

In experiments in which the presence of both RCMV DNA and mRNA in tissue samples or RCMV-infected REF cells was evaluated, the Wizard genomic DNA purification kit (Promega, Leiden, the Netherlands) was used. The isolation was performed essentially as prescribed by the manufacturers, with some modifications. Briefly, cells or small tissue 
samples $( \pm 25 \mathrm{mg}$ ) were added to $300 \mu \mathrm{l}$ of the Nuclei Lysis Solution containing $60 \mu \mathrm{g}$ of proteinase K (Roche molecular diagnostics, Mannheim, Germany) and incubated at $56^{\circ} \mathrm{C}$ for 1 to 2 hours until complete lysis. A water sample was included after every ninth tissue sample to serve as a negative control for cross-contamination during the isolation procedure. The subsequent RNase step in the standard protocol was omitted to allow the isolation of both total cellular DNA and RNA. Instead, the samples were directly incubated for $5 \mathrm{~min}$ at $4^{\circ} \mathrm{C}$ after $100 \mu \mathrm{l}$ of the Protein Precipitation Solution was added. The samples were subsequently centrifuged at $20,000 \times \mathrm{g}$ for $20 \mathrm{~min}$. The supernatant was transferred to a new reaction tube which contained 1 volume of isopropanol and $1 \mu \mathrm{g}$ of glycogen. After incubation for $10 \mathrm{~min}$ at room temperature and subsequent centrifugation at $20,000 \times \mathrm{g}$ for $10 \mathrm{~min}$, the pellet was washed with $70 \% \mathrm{EtOH}$ and air-dried for $30 \mathrm{~min}$ at room temperature. The pellet was dissolved in $50 \mu \mathrm{l}$ of $\mathrm{H}_{2} \mathrm{O}$ by incubation for 1 hour at $65^{\circ} \mathrm{C}$. The total nucleic acid concentration was determined by measuring the $O D$ at $260 \mathrm{~nm}$. Part of this total nucleic acid preparation was used to perform a single-tube nested PCR reaction for the detection of RCMV DNA. The remaining DNA and RNA was treated with 20 units of DNase I (Amersham Pharmacia Biotech, Roosendaal, the Netherlands), in the presence of $10 \mathrm{mM} \mathrm{MgCl}, 1 \mathrm{mM}$ DTT, 10 units of RNAguard (Amersham Pharmacia Biotech), and $10 \mathrm{mM}$ Tris $\mathrm{pH} 7.5$ in a total volume of $100 \mu \mathrm{l}$ for 1 hour at $37^{\circ} \mathrm{C}$. Thereafter, the DNasel was inactivated at $70^{\circ} \mathrm{C}$ for $10 \mathrm{~min}$. The RNA was directly precipitated by adding 1 volume of isopropanol and incubation of the samples at $-70^{\circ} \mathrm{C}$ for at least one hour. After centrifugation at $20,000 \times \mathrm{g}$ for $10 \mathrm{~min}$, the pellet was washed with $70 \% \mathrm{EtOH}$, air-dried at room temperature for $30 \mathrm{~min}$ and dissolved in $50 \mu \mathrm{l}$ of $\mathrm{H}_{2} \mathrm{O}$. The RNA concentration was determined by measuring the OD at $260 \mathrm{~nm}$. For the majority of samples from the salivary glands, it was found that RT-PCR was frequently inhibited. Therefore, isolation of RNA from salivary gland tissues was repeated using an alternative method for the direct isolation of total RNA by guanidine thiocyanate, essentially as described by Chomczynski and Sacchi (20).

Plasmid constructs. The single-tube nested PCR reaction was optimized in vitro using a plasmid that contains the target DNA sequence. This plasmid was also used to spike PCR reactions in order monitor the presence of PCR inhibitors. The PCR control DNA was constructed by cloning part of the RCMV genomic sequence (61), corresponding to position 172,719 to 173,428 (GenBank accession number AF232689), cloned into the HincII site of pUC119. An additional EcoRI fragment of $129 \mathrm{bp}$, corresponding to position 215,968 to 216,096 of the RCMV genomic sequence, was cloned into the EcoRI site of the insert at position 173,042 . As a result of this insertion, the fragment generated by PCR from this control plasmid is $123 \mathrm{bp}$ larger than the PCR fragment that is generated from RCMV 
genomic DNA ( 369 bp versus $246 \mathrm{bp}$ ). These fragments can easily be distinguished by agarose gel electrophoresis.

The control RNA that was used in the different RT-PCR assays was generated in vitro from plasmids that contain a T7 RNA polymerase promoter directly upstream of the inserted cDNA. The control RNA was used to optimize the different RT-PCR reactions in vitro and was also used as a spike to monitor the presence of RT-PCR inhibitors. The IE-1 and $B$-actin proteins are encoded by spliced transcripts $(5,46)$. The cDNA of these transcripts was obtained by the isolation of poly(A) mRNA from RCMV-infected REF cells, using the Quickprep Micro mRNA purification kit (Amersham Pharmacia Biotech). Firststrand cDNA was subsequently generated by reverse transcription using an oligo-dT primer (3'RACE-1; 5'-GTACGATTCGGACACCCTGCAG(T) $17^{\prime} 3^{\prime}$ ) and Superscript II RT, as described by the manufacturer. For cloning part of the cDNA encoding IE- 1 , the primers RCMVMIE-2a (5'-ATGGAACTCAGCAACCCCAGG-3'; corresponding to the complement of position 173,715 to 173,735 of the RCMV genomic sequence) and RCMVMIE-3b (5'GTTGTAGGACCTTAGCGATGATGTTC-3'; corresponding to position 172,719 to 172,744 of the RCMV genomic sequence) were used. The amplified cDNA fragment contained part of exon 3 and 4 of the IE-1 mRNA (5). The PCR fragments were treated with T4 DNA polymerase to generate blunt ends, 5 '-phosphorylated using polynucleotide kinase and cloned into the Hincll site of vector pBluescriptSK(+) (Stratagene, Heidelberg, Germany), which was dephosphorylated before ligation. The cDNA for the B-actin gene was generated using primers RT-ACT-B (5'-GGTGGGTATGGGTCAGAAGG-3'; corresponding to position 1,462 to 1,481 of the DNA sequence with Genbank accession no. J00691) and RT-ACT-F (5'TGCCGATAGTGATGACCTGA-3'; corresponding to the complement of the DNA sequence from position 2,529 to 2,548). The PCR fragments were treated with T4 DNA polymerase, 5'-phosphorylated, and cloned into vector pGEM3z (Promega), which was restricted with EcoRI, treated with Klenow enzyme, and dephosphorylated before ligation. This vector was also used for cloning of the R32 and R44 cDNA fragments. In contrast to IE-1 and B-actin, the mRNAs that are transcribed from these genes are not spliced $(8,31)$. The cDNA of these genes was directly subcloned from genomic RCMV DNA. For the R44 gene, a Narl-Ncol restriction fragment was cloned, corresponding to position 41,295 to 42,300 of the RCMV genomic sequence. The fragment was trei.ed with Klenow before ligation. For the R32 gene, a Smal-Sacl restriction fragment was cloned, corresponding to position 25,458 to 26,011 of the RCMV genomic sequence. The fragment was treated with T4 DNA polymerase to generate blunt ends before ligation. The DNA sequence of all inserts was determined to check the orientation of the insert and to confirm the absence of mutations. 
In vitro synthesis of RNA. T7 RNA polymerase was used to synthesize RNA in vitro from PCR fragments. These PCR fragments were generated from pGEM $3 z$ or pBluescript plasmids that contain IE-1, R44 or R32 cDNA, using the universal pUC/M13 forward and reverse primers. The T7 RNA polymerase (Roche molecular diagnostics) was incubated with 100 to $200 \mathrm{ng}$ of purified PCR fragment for 2 hours at $37^{\circ} \mathrm{C}$ in a total volume of $20 \mu \mathrm{l}$ using reaction conditions as described by the manufacturer. Thereafter, 10 units of DNasel (Amersham Pharmacia Biotech) were added to the reaction mixture, which was subsequently incubated for another $30 \mathrm{~min}$ at $37^{\circ} \mathrm{C}$. After addition of $2 \mu \mathrm{l}$ of $0.2 \mathrm{M}$ EDTA (pH 8.0), the RNA was precipitated by adding $2.5 \mu \mathrm{l}$ of $4 \mathrm{M} \mathrm{LiCl}$ and $75 \mu \mathrm{l}$ of prechilled $\left(-20^{\circ} \mathrm{C}\right) \mathrm{EtOH}$, and incubation at $-70^{\circ} \mathrm{C}$ for at least 1 hour. The RNA was pelleted by centrifugation at $20,000 \times \mathrm{g}$, and subsequently washed with ice-cold $70 \% \mathrm{EtOH}$. The pellet was dissolved in $100 \mu \mathrm{l} \mathrm{H}_{2} \mathrm{O}$ and the concentration of RNA was determined by measuring the OD at $260 \mathrm{~nm}$. The RNA was aliquoted in portions of $1 \times 10^{8} \mathrm{copies} / \mu \mathrm{l}$ and stored at $-70^{\circ} \mathrm{C}$. For each new RT-PCR run, an aliquot was thawed and used to make fresh dilutions.

PCR. For the detection of genomic RCMV DNA, we used a single-tube nested PCR with primers which are located within exon 4 of the IE-1 gene, as described previously (6), except that the $\mathrm{MgCl}_{2}$ concentration was $2.0 \mathrm{mM}$ in stead of $1.5 \mathrm{mM}$. This PCR results in the amplification of a 246-bp DNA fragment. In experiment I, $1 \mu \mathrm{g}$ of the isolated nucleic acids was added to the PCR reactions. However, for blood plasma, PBL, aorta and left carotid artery the yield of isolated nucleic acids was relatively low. Therefore, it was not always possible to include $1 \mu \mathrm{g}$ of nucleic acids in the PCR reaction. To dilute potential PCR inhibitors, reactions were also performed with 0.1 or $0.01 \mu \mathrm{g}$ of nucleic acids. In experiment II, PCR reactions were performed using an input of 1 or $0.1 \mu \mathrm{g}$. To determine the presence of potential PCR inhibitors in this experiment, each of the reactions was performed in duplicate, either in the presence or absence of 10 copies of the PCR control DNA. A PCR result was considered as invalid if the PCR control DNA could not be detected. Again, the yield of isolated nucleic acids from PBL, aorta, left carotid artery and, in particular, blood plasma, was not always sufficient to include $1 \mu \mathrm{g}$ of nucleic acids in the PCR reaction. However, this occurred less frequently in experiment II than in experiment I. In both experiments, the sensitivity of the single-tube nested PCR was monitored during every run by testing dilutions of the PCR control DNA in water. Furthermore, PCR reactions with water instead of nucleic acids were included as negative controls. After amplification, PCR products were analyzed by agarose gel electrophoresis and ethidium bromide-staining.

RT-PCR. The synthesis of CDNA and its subsequent amplification by PCR was performed in a single tube. Improved sensitivity for the detection of IE-1, R32 and R44 mRNA was obtained by performing an additional nested PCR. The reaction mixtures for 
RT-PCR were prepared on ice and contained $1 \mu \mathrm{g}$ of total RNA isolate, $2 \mu \mathrm{g}$ of brewer's yeast tRNA (Roche molecular diagnostics), $0.2 \mathrm{mM}$ dNTPs, $5 \mathrm{mM}$ DTT, $0.2 \mu \mathrm{M}$ of each primer (for RCMV RT-PCR primers, see Table 1), 10 units of RNAguard (Amersham Pharmacia Biotech), 1.25 units of HotstarTaq DNA polymerase (Qiagen, Leusden, the Netherlands), 10 units of Superscript II RT (Gibco BRL Life technologies, Breda, the Netherlands), and $1 \times$ HotstarTaq reaction buffer, containing $1.5 \mathrm{mM} \mathrm{MgCl} 2$ (Qiagen). For the detection of IE-1 mRNA by RT-PCR, the reaction was supplemented with $0.5 \mathrm{mM}$ $\mathrm{MgCl}_{2}$ (Qiagen). As a positive control, we also performed RT-PCR on cellular B-actin mRNA using the primers RT-ACT-B and RT-ACT-F (see plasmid constructs section above). RT-PCR using these primers results in the amplification of a fragment of $622 \mathrm{bp}$. Since the primers flank an intron in the B-actin gene, the RT-PCR product is 464 bp smaller than the PCR product that would be generated on genomic DNA (46).

The total RNA isolates were used as input for each RT-PCR. For each measurement three control reactions were included. One of these reactions contained only the total RNA isolate, and amplification was performed without RT. The other two reactions contained the total RNA isolate, and were spiked with in vitro synthesized control RNA. The amplification of these samples was also performed either with or without RT. The spiked samples served to monitor the presence of potential PCR inhibitors. An RT-PCR result was considered as invalid if the control RNA could not be detected. As a spike, 10 copies of both IE-1 and R44 control RNA were used, whereas 50 and $5 \times 10^{3}$ copies of R32 and B-actin control RNA were used, respectively. The reactions with and without RT were used to demonstrate the specific amplification of mRNA instead of genomic DNA. Furthermore,

TABLE 1. Primers used for single-tube RT-PCR, followed by additional nested PCR.

\begin{tabular}{|c|c|c|c|c|}
\hline Primer & Sequence $\left(5^{\prime}-3^{\prime}\right)$ & $\begin{array}{l}\text { Position in RCMV } \\
\text { genomic sequence }\end{array}$ & Function & $\begin{array}{c}\text { Size of } \\
\text { PCR product [bp] }\end{array}$ \\
\hline RT-IE1-F2 & CTCTCTGTGCGGCTTC & $172,857-172,872$ & $1^{\text {st }}$ strand $\mathrm{CDNA}$ synthesis & \\
\hline RT-IE1-B2 & AACCCAGACCACCGAAC & $173,497-173,513^{b}$ & $2^{\text {nd }}$ strand cDNA synthesis & 559 \\
\hline IE1-NRT-F & TTCTAACCGATCCAGAACCA & $173,447-173,466^{b}$ & nested PCR forward primer & \\
\hline IEI-NRT-R & GCGAATCTCATCACCATTTC & $173,174-173,193$ & nested PCR reverse primer & 195 \\
\hline RT-R44-F1 & GAGTTGGCCTGGTAGTTGGA & $41,391-41,410$ & $1^{\text {st }}$ strand $\mathrm{cDNA}$ synthesis & \\
\hline RT-R44-B1 & CCCGACTTCAACATGGACTT & $41,895 \cdot 41,914^{b}$ & $2^{\text {nd }}$ strand $C D N A$ synthesis & 523 \\
\hline R44-NRT-B2 & AACACCGAGGTCGAGTTCAC & $41,655-41,674^{b}$ & nested PCR forwand primer & \\
\hline R44-NRT-F2 & GCTGAGGAAGTTCTCGATGG & $41,462-41,481$ & nested PCR reverse primer & 212 \\
\hline RT-R32-F3 & CGTATGAGGTTGAGGCGAT & $25,505-25,523$ & $1^{\text {st }}$ strand $\mathrm{CDNA}$ synthesis & \\
\hline RT-R32-B3 & CTATGGCTCCGCTACTACGA & $25,988-26,007^{b}$ & $2^{\text {nd }}$ strand CDNA synthesis & 502 \\
\hline R32-NRT-B2 & AACTCTCGCCCTACTTC & $25,876-25,892^{b}$ & nested PCR forwand primer & \\
\hline R32-NRT-A2 & TAGGTGTGGAGGTTATC & $25,655-25,671$ & nested PCR reverse primer & 237 \\
\hline
\end{tabular}

a Genbank sequence accession no. AF232689 (61).

b Primer sequence is complementary to RCMV genomic sequence. 
the sensitivity of the RT-PCR assay was monitored during every single run by testing dilutions of control RNA in a background of $2 \mu \mathrm{g}$ of brewer's yeast tRNA. Negative controls consisted of RT-PCR reactions on water instead of nucleic acids.

Total RNA was first incubated at $65^{\circ} \mathrm{C}$ for $5 \mathrm{~min}$ and subsequently cooled on ice for $5 \mathrm{~min}$, before it was added to the RT-PCR reaction mixtures. The reaction tubes were transferred from the ice to the thermal cycler once they had reached the appropriate temperature for reverse transcription. The RT-PCR reactions were performed on a PTC-200 thermal cycler (MJ Research Inc., Watertown, Massachussets), which was programmed to perform an initial incubation step of $20 \mathrm{~min}$ at the temperature for reverse transcription (Trt; see below), followed by $15 \mathrm{~min}$ at $95^{\circ} \mathrm{C}, 40$ cycles (for IE-1, R44 and R32 RT-PCR) or 50 cycles (for B-actin RT-PCR) of $30 \mathrm{~s}$ at $95^{\circ} \mathrm{C}, 30 \mathrm{~s}$ at melting temperature ( $\mathrm{Tm}$; see below) and $30 \mathrm{~s}$ at $72^{\circ} \mathrm{C}$, concluded with $5 \mathrm{~min}$ at $72^{\circ} \mathrm{C}$. For the detection of IE and B-actin mRNA, Trt was $55^{\circ} \mathrm{C}$, and $\mathrm{Tm}$ was 58.5 or $65^{\circ} \mathrm{C}$, respectively. For the detection of R32 and R44 mRNA, Trt was $50^{\circ} \mathrm{C}$ and $\operatorname{Tm}$ was $63^{\circ} \mathrm{C}$ or $60^{\circ} \mathrm{C}$, respectively. For nested PCR, $5 \mu$ of the RT-PCR reaction was transferred to a reaction mixture containing $0.2 \mu \mathrm{M}$ of each of the nested primers (see Table 1), $0.1 \mathrm{mM}$ dNTPs, 1 x HotstarTaq PCR buffer, containing $1.5 \mathrm{mM}$ $\mathrm{MgCl}_{2}$, and 1.25 units of HotstarTaq in a total volume of $50 \mu \mathrm{l}$. The PCR reaction was performed by incubation for $15 \mathrm{~min}$ at $95^{\circ} \mathrm{C}, 35 \mathrm{cycli}$ of $30 \mathrm{~s}$ at $94^{\circ} \mathrm{C}, 30 \mathrm{~s}$ at $\mathrm{Tm}, 30 \mathrm{~s}$ at $72^{\circ} \mathrm{C}$, and a final incubation step of $5 \mathrm{~min}$ at $72^{\circ} \mathrm{C}$. The $\mathrm{Tm}$ for the nested amplification of cDNA from IE-1, R32, and R44 mRNA was 60,58 and $65^{\circ} \mathrm{C}$, respectively. The PCR products were analyzed by agarose gel electrophoresis and ethidium bromide-staining.

Rapid amplification of cDNA ends (RACE). The 5'RACE System Version 2.0 (Gibco BRL Life technologies) was used for determination of the $5^{\prime}$ ends of the antisense transcripts as described previously (5). First, poly(A) mRNA was isolated from RCMV-infected REF cells at 48 hours after infection, using the QuickPrep Micro mRNA Purification kit. Firststrand CDNA was generated using primer RT-IE1-B2 (for primer sequences see Fig. 9). After tailing the cDNA with $\mathrm{dCTP}$ and terminal deoxynucleotidyl transferase, PCR was performed using the " 5 'RACE Abridged Anchor Primer" (AAP, Gibco BRL Life technologies) and the internal gene-specific primer IE1-NRT-F. A second, semi-nested PCR was subsequently performed using the "Abridged Universal Amplification Primer" (AUAP, Gibco BRL Life technologies) and the gene-specific primer $3 \mathrm{~F} 2$.

To amplify the $3^{\prime}$ end of the antisense transcripts, 3'RACE was performed using poly(A) mRNA from RCMV-infected REF. The primer 3'RACE-RL-1 was used to generate cDNA using Superscript II RT under conditions as described by the manufacturer. A first round of PCR was subsequently performed with primer 3'RACE-N1 and the gene-specific primer pInt3IE. A second, nested PCR was performed with primer 3'RACE-N2 and the gene-specific 
primer p-Int3IEnes. PCR mixtures contained $0.4 \mu \mathrm{M}$ of each primer, $0.1 \mathrm{mM}$ of each dNTP, 1.25 units of HotstarTaq DNA polymerase, $1 \times$ HotstarTaq polymerase buffer, and $5 \mu$ of cDNA or $100 \times$ diluted first-round PCR product, in a total volume of $50 \mu \mathrm{l}$. Amplification $\left(15 \mathrm{~min}\right.$ at $95^{\circ} \mathrm{C}, 35$ cycles of subsequently $1 \mathrm{~min}$ at $94^{\circ} \mathrm{C}, 1 \mathrm{~min}$ at $55^{\circ} \mathrm{C}$, and $1 \mathrm{~min}$ at $72^{\circ} \mathrm{C}$, and a final incubation of $5 \mathrm{~min}$ at $72^{\circ} \mathrm{C}$ ) was performed in a PTC-200 thermal cycler. The resulting RACE fragments were T-A cloned using the pGemTeasy vector (Promega) and sequenced.

\section{RESULTS}

Dissemination of RCMV in immunocompetent rats. In an initial experiment, which will be further referred to as experiment I, 30 immunocompetent rats were infected with RCMV. Five rats were subsequently sacrificed at either day $3,5,7,14,31$ or 120 pi. Organs were collected from these rats and analyzed for the presence of infectious virus using the plaque titration assay. In addition, total nucleic acids were isolated and used for the detection of RCMV DNA by a PCR assay. As shown in Fig. 1 (lane 4), this assay is able to reproducibly detect at least 10 copies of PCR control DNA. The number of DNA-positive organs in each group of 5 rats at the different time-points after infection was determined (Fig. 2). RCMV DNA could first be detected in spleen, liver, lungs, heart, pancreas, thymus and aorta, at day 3. However, within the first week pi, RCMV DNA was also detected in the other tissues and organs, except in blood plasma. The inability to detect RCMV DNA in

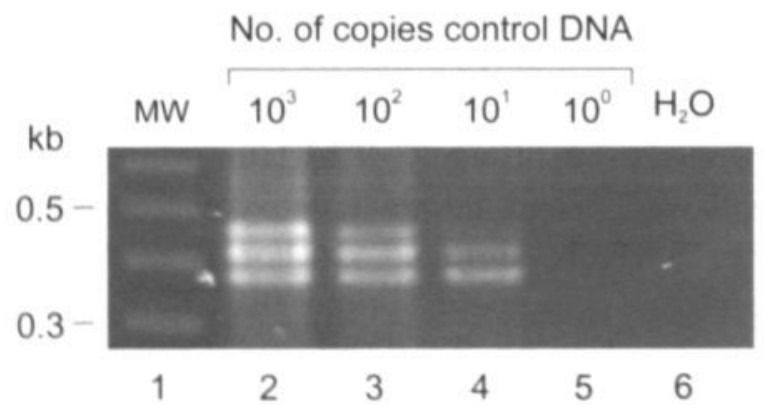

FIG. 1. Sensitivity of the single-tube, nested RCMV PCR. Ten-fold dilutions of PCR control DNA were made from $1 \times 10^{3}$ copies down to 1 copy and tested by PCR (lane 2,3,4,5). Water was also used as input in the PCR and served as a negative control (lane 6). Molecular weight (MW) marker sizes are indicated on the left of the panel (lane 1). The expected size for the amplification product of PCR control DNA is $369 \mathrm{bp}$. This is 123 bp larger than the fragment that would be generated from RCMV genomic DNA (see Materials and Methods). The additional DNA fragments with sizes greater than $369 \mathrm{bp}$ are the result of amplification mediated by different inner and outer primer pair combinations. 


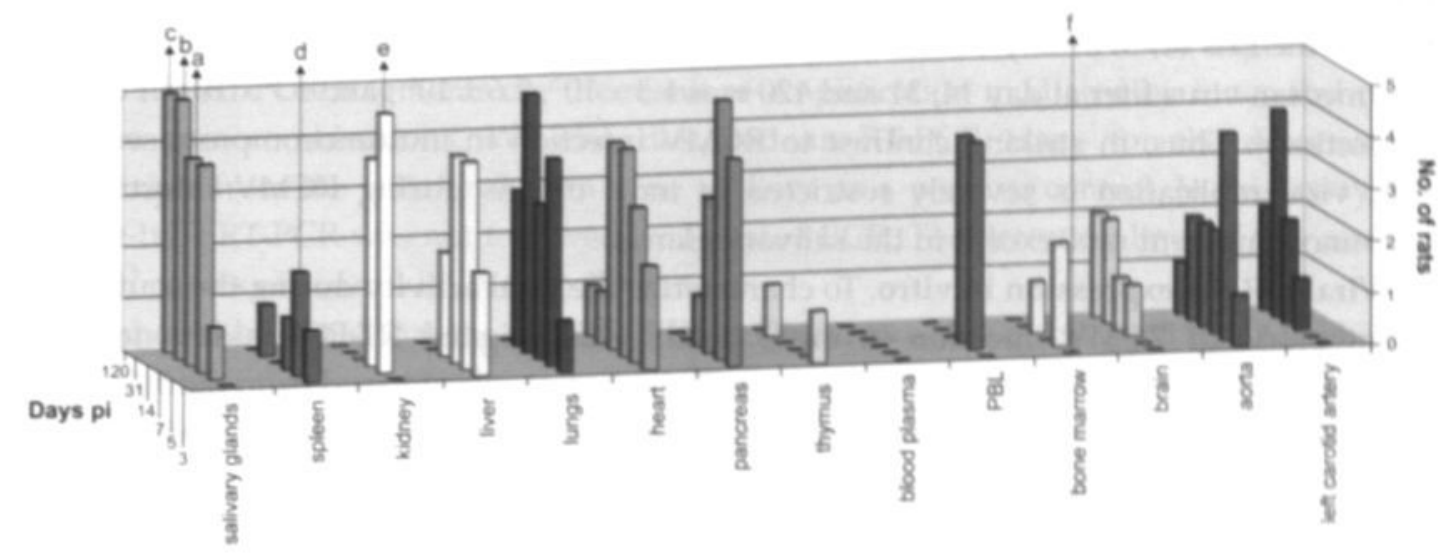

FIG. 2. Detection of RCMV DNA by PCR in rat organs and tissues at various time-points pi. At cach timepoint, 5 rats were sacrificed and organs were collected for PCR and plaque titration-assay. Bars indicate the number of rats that are RCMV DNA-positive for each organ at a given time-point. The arrows mark the plaque assay-positive organs. a, 4 plaque assay-positive rats, median virus titer $1.3 \times 10^{5} \mathrm{PFU} / \mathrm{ml} ; b, 5$ plaque assaypositive rats, median virus titer $2.6 \times 10^{6} \mathrm{PFU} / \mathrm{ml} ; \mathrm{c}, 5$ plaque assay-positive rats, median virus titer $5.7 \times 10^{4}$ PFU/ml; d, 1 plaque assay-positive rat, $110 \mathrm{PFU} / \mathrm{ml} ; \mathrm{e}, 1$ plaque assay-positive rat, $67 \mathrm{PFU} / \mathrm{ml} ; \mathrm{f}, 1$ plaque assay-positive rat, $167 \mathrm{PFU} / \mathrm{ml}$.

blood plasma indicates that the virus is predominantly cell-associated. For most organs, the highest number of RCMV DNA-positive samples was seen within the first week pi. However, the highest number of positive samples from salivary glands, lungs, brain and left carotid artery was found at later time-points, namely at day 14 (lungs) or day 31 (salivary glands, brain and left carotid artery). In one of the rats that was sacrificed at day 7, RCMV DNA was not detected in any organ. Therefore, it is likely that this animal had not been successfully infected with RCMV.

At 120 days pi, the salivary glands of all rats contained RCMV DNA, whereas in the other organs RCMV DNA could be detected in the heart, brain, aorta and left carotid artery for a maximum of two rats. However, detection appeared to be random and was not restricted to the same rat(s) within the group of 5 (data not shown).

Although RCMV DNA could be detected at least once in most organs from 3 to 120 days pi, infectious virus was only detected in three organs in that period (bone marrow at day 3 , spleen and kidney at day 5), obtained from three different rats. Moreover, the virus titers in these organs were low: 167, 110 and $67 \mathrm{PFU} / \mathrm{ml}$ of a $10 \% \mathrm{w} / \mathrm{v}$ organ suspension for bone marrow, spleen and kidney, respectively. Surprisingly, RCMV DNA was not detected by PCR in the plaque assay-positive bone marrow. Most likely, this was due to the presence of PCR inhibitors in the nucleic acid isolate. In contrast to the limited number of plaque assay- 
positive results for most organs, infectious virus could be detected in the salivary glands of $80 \%$ of the rats $(4 / 5)$ at day 14 , and in $100 \%$ of the rats $(5 / 5)$ at both day 31 and day 120 . The median virus titer at day 14,31 and 120 was $1.3 \times 10^{5}, 2.6 \times 10^{6}$, and $5.7 \times 10^{4} \mathrm{PFU} / \mathrm{ml}$, respectively. Thus, in striking contrast to RCMV infection in immunocompromised rats (55), viral replication is severely restricted in most organs during RCMV infection of immunocompetent rats, except in the salivary gland.

Viral mRNA expression in vitro. To characterize the viral activity during the acute and latent phase of RCMV infection in more detail, we designed RT-PCR assays for the detection of three different RCMV transcripts. These transcripts, derived from the R123 (IE1), R44 and R32 genes, are representatives of each of the kinetic classes of viral gene expression in vitro, namely IE, early and late, respectively. Each RT-PCR was performed in a single tube, followed by a separate nested PCR for increased sensitivity. The assays are able to detect at least 10 copies of in vitro generated control RNA (Fig. 3A, lane 6; Fig. 3B,

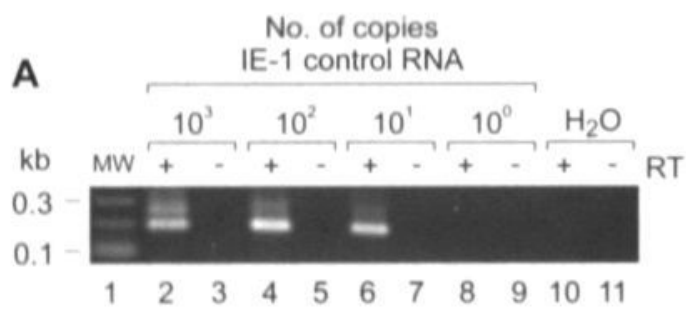

No. of copies

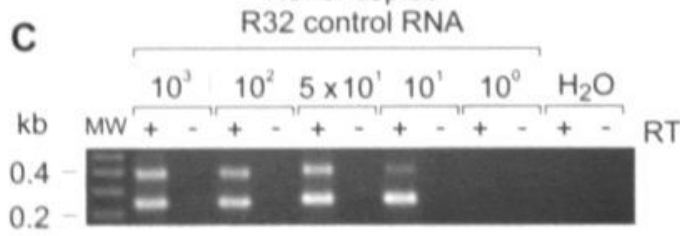

$\begin{array}{llllllllllllll}1 & 2 & 3 & 4 & 5 & 6 & 7 & 8 & 9 & 10 & 11 & 12 & 13\end{array}$

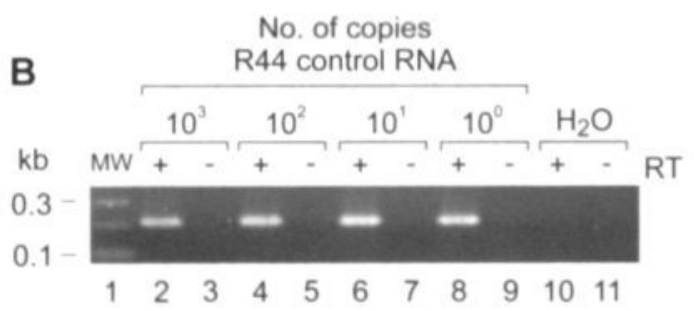

No. of copies

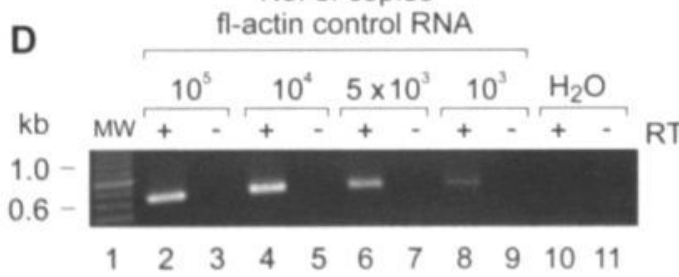

FIG.3. The sensitivity of single-tube (nested) RT-PCR for the detection of RCMV IE-1, R44 and R32 control RNA and the cellular B-actin control RNA. Ten-fold dilutions of $I E-1(A), R 44(B)$ and $R 32$ (C) control RNA were made from $1 \times 10^{3}$ copies down to 1 copy, and tested by $R T-P C R$ in the presence $(+)$ or absence $(-)$ of reverse transcriptase (RT) as indicated above each panel. Water was also used as input in the RT-PCR and served as a negative control $\left(\mathrm{H}_{2} \mathrm{O}\right)$. Molecular weight ( $\left.\mathrm{MW}\right)$ marker sizes are indicated on the left side of each panel (lane 1). The expected size of the nested PCR fragments after amplification of CDNA is 195 bp for IE-1. 212 bp for R44 and 237 bp for R32 RNA (see Table 1). For R32 RT-PCR, 50 copies of control RNA were also tested (lane 6 and 7). (D) Dilutions of 6-actin control RNA were made from $1 \times 10^{5}$ down to $1 \times 10^{3}$ copies, and tested by RT-PCR in the presence (+) or absence (-) of RT as indicated above the panel. Water was included as a negative control (lane 10 and 11). The expected size for PCR fragments is $622 \mathrm{bp}$. 
lane 6; Fig. 3C, lane 8). Incidentally, also 1 copy of the IE-1 (data not shown) and R44 control RNA could be detected (Fig. 3B, lane 8). The observed fragments with a size larger than that of the nested PCR fragments are the result of amplification mediated by inner and outer primer pair combinations. We also designed an RT-PCR assay for the detection of transcripts from the cellular B-actin gene to serve as a positive control. In this assay, the single-tube RT-PCR was not followed by a nested PCR. The detection limit of this assay is $1 \times 10^{3}$ copies of control RNA (Fig. 3D, lane 8).

It should be noted that the amplified IE-1 CDNA has a size of 195 bp (Fig. 3A), which is 97-bp smaller than amplified genomic DNA, since primers were used that flank intron 3 of R123. The primers that were used to amplify B-actin mRNA also flank an intron. As a consequence, amplified B-actin cDNA has a size of 622 bp (Fig. 3D), whereas amplified cellular DNA has a size of 1086 bp (data not shown). In contrast, the R32 and R44 genes are not spliced. Therefore, it is not possible to discriminate between RT-PCR products derived from either genomic DNA or cDNA. Nevertheless, the RT-PCRs that were performed for the analysis of viral mRNA expression in rat organs were always accompanied by a control reaction from which RT was omitted. Thus, possible amplification of residual genomic DNA could always be excluded.

For the combined isolation of DNA and RNA from the same sample, we used a different isolation method than that used in experiment I (see Materials and Methods). The complete procedure, from total nucleic acid isolation to PCR and RT-PCR, was tested on RCMVinfected REF (Fig. 4). At 48 hours after infection, total nucleic acids were isolated and used as input in the single-tube nested PCR. Ten-fold dilutions of the total nucleic acids were tested from $10 \mathrm{ng}$ to $10 \mathrm{fg}$. The lowest amount of total nucleic acids in which RCMV DNA could still be detected was $0.1 \mathrm{pg}$ (Fig. 4A, lane 7). Subsequently, total nucleic acid samples were treated with DNaseI, and the remaining total RNA was used as input for the different RT-PCRs. Again, ten-fold dilutions of total RNA were tested, from $0.1 \mu \mathrm{g}$ to $0.1 \mathrm{pg}$, both with or without addition of RT to the reaction mixtures. The lowest amount of total RNA in which R44, R32 and B-actin mRNA could still be detected was 1 pg (Fig. 4C, 4D and 4E, lane 12), whereas for IE-1 mRNA this was $10 \mathrm{pg}$ (Fig 4B, lane 10). For IE-1, R44 and R32 RT-PCR results, fragments were observed with a size larger than that of the nested PCR fragments, in particular with higher RNA input concentrations. Again, these are the result of amplification mediated by inner and outer primer pair combinations. In addition, amplification occurred in the minus RT reaction for IE-1 (Fig. 4B, lane 3 and 5), R44 (Fig. 4C, lane 3), and R32 (Fig. 4D, lane 3 and 5), with a high input of total RNA. These results demonstrate that only at high input concentrations, residual DNA can be amplified. Nevertheless, as mentioned above, the possible amplification of residual DNA in our RTPCR assays is controlled for by performing reactions both in the presence and absence of RT. 


\section{A DNA}

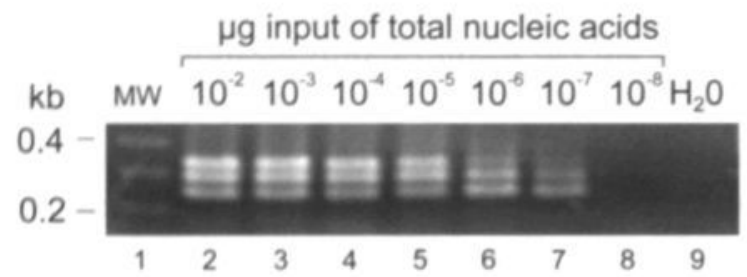

B IE-1

$\mu \mathrm{g}$ input of total RNA

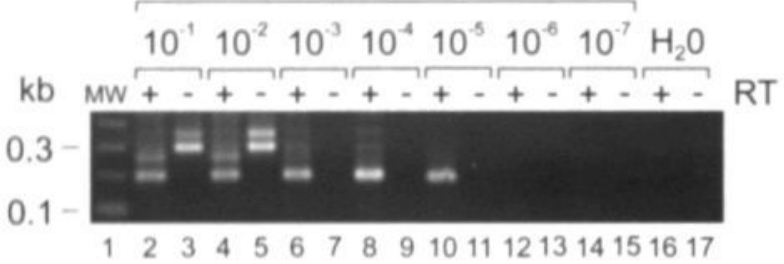

C $\mathbf{R 4 4}$

$\mu \mathrm{g}$ input of total RNA

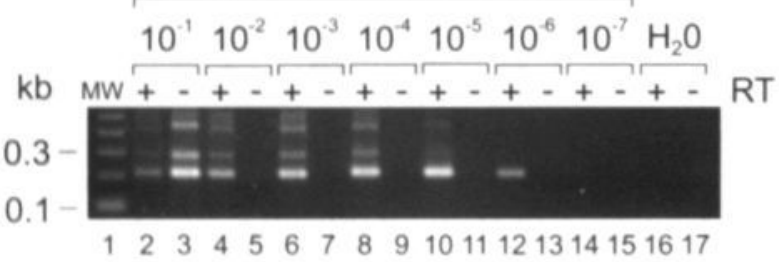

D R32

$\mu \mathrm{g}$ input of total RNA

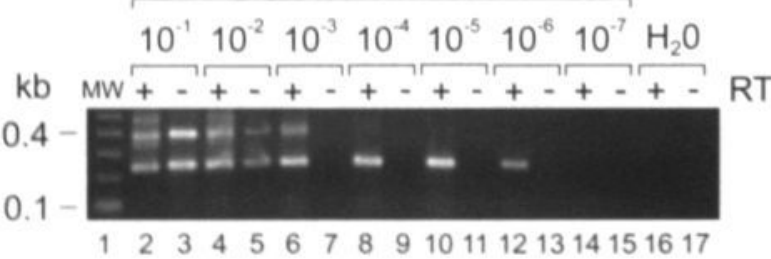

\section{E Actin}

$\mu \mathrm{g}$ input of total RNA

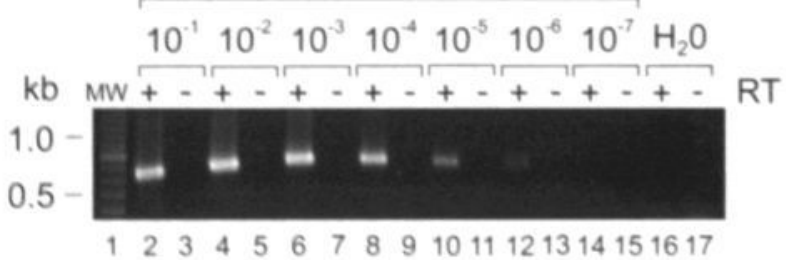


\& FIG. 4. Detection of RCMV DNA and mRNA in RCMV-infected REF at 48 hours pi. (A) Ten-fold dilutions of total nucleic acid isolates were made from 10 ng to $10 \mathrm{fg}$ and tested by single-tube, nested PCR. Water was also used as imput in the PCR and served as a negatioe control (lane 9). Molecular weight (MW) size markers are indicated on the left of the panel (lane 1). The expected size for the amplification product of genomic RCMV DNA is $246 \mathrm{bp}$. The additional larger DNA fragments are the result of amplification mediated by different imner and outer primer pair combinations. For the detection of $m R N A$, ten-fold dilutions of total RNA isolates were made from $0.1 \mu \mathrm{g}$ to $0.1 \mathrm{pg}$ and tested by the IE-1 (B), R44 (C), R32 (D), and B-actin (E) RT-PCR assary, in the presence $(+)$ or absence $(-)$ of reverse transcriptase $(R T)$ as indicated above cach panel. Water served as a negative control (lane 17). MW size markers are indicated on the left side of each panel. The expected size of the nested PCR fragments after amplification of cDNA is 195 bp for IE-1, 212 bp for R44 and 237 bp for R32 RNA (see Table 1). For IE-1, RT-PCR primers were used that flank intron 3 of the R123 gene (see Materials and Methods). As a consequence, the PCR product generated from IE-1 genomic R123 DNA is larger than that generated from IE-1 cDNA (292 bp versus 195 bp). Since the R44 and R32 genes do not contain intron sequences, a similar approach to discriminate between amplified genomic DNA and cDNA is not possible.

In conclusion, the combined isolation of DNA and RNA from RCMV-infected REF enabled efficient amplification of RCMV DNA as well as mRNAs. Furthermore, the expression of IE-1 mRNA at 48 hours pi appears to be 10-fold lower than that of both R44 and R32 mRNA. This is in concordance with previous reports, which demonstrated that R44 and R32 mRNA are detected by Northern blot analysis during the late phase of infection in vitro $(8,31)$, whereas IE-1 mRNA is not (5).

In vivo RCMV mRNA expression at day 7 and 120 after infection. After optimization of the different RT-PCR assays as well as the protocol for combined isolation of DNA and RNA, we set out to analyze viral mRNA expression in vivo. Since the DNA isolates from experiment I were not suitable for mRNA analysis and the amount of residual organ and tissue material was not sufficient for the extraction of both DNA and RNA, we performed a second infection experiment. In this experiment (experiment II) a group of 10 rats was infected with an equal amount of virus from the same virus pool as used in experiment $\mathrm{I}$. The rats were sacrificed at either day $7(n=5)$ or day $120 \mathrm{pi}(n=5)$. These time-points were chosen since they are representative for acute and persistent/latent RCMV infection, respectively. Both DNA and RNA were isolated from a similar set of organs as described for experiment $I$. The detection of infectious virus by plaque assay was restricted to the salivary glands, spleen and liver. Since infectious virus is generally not detected in the salivary glands before day 10 (11), the plaque assay was carried out exclusively on salivary gland samples obtained at day 120 pi.

As shown in Fig. 5 and 6, the number of RCMV DNA-positive organs and the number of positive rats per organ was found to be somewhat higher in experiment II than in experiment I, both at day 7 and 120. This difference between experiment I and experiment II can be explained by the use of different nucleic acid isolation procedures in these experiments. 
experiment 1 day 7 p.i.

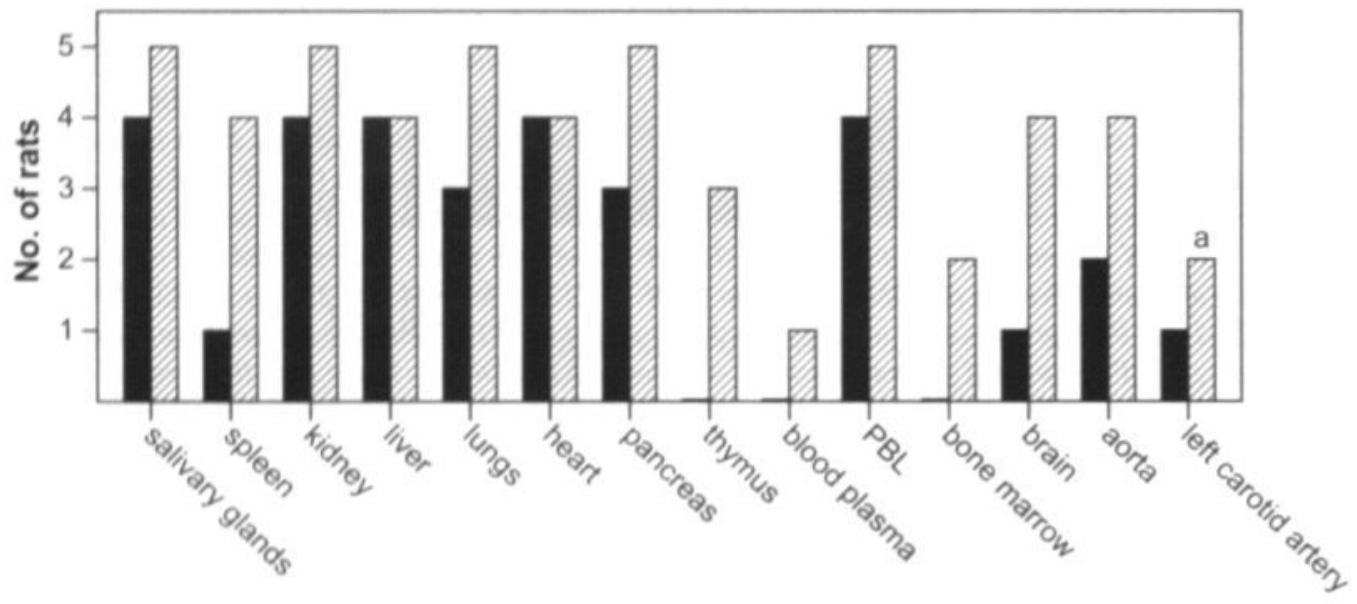

FIG. 5. RCMV DNA detection by PCR in various rat organs and tissues at 7 days pi, in experiment I and II. The number of rats that were RCMV DNA-positive for one specific organ is indicated by black and hatched bars, representing experiment I and II, respectively. a indicates that for two samples an invalid PCR result was obtained due to the inability to amplify the spike of control DNA added to the PCR reaction.

RCMV DNA could be detected in all organs at day 7 (Fig. 5), including thymus, blood plasma and bone marrow, which were DNA-negative in experiment I. Further analysis of the viral mRNA expression at day 7 was performed for 2 of the 5 rats (Fig. 7). The PCR results from these selected rats were representative for those of the whole group. As a result of the combined isolation of DNA and RNA, the results for PCR and RT-PCR can be directly related to the same isolate from the same sample. As a positive control, RT-PCR was performed on cellular B-actin mRNA. This mRNA could be detected in all organs, except in the pancreas and blood plasma, which is a cell-free fraction. The inability to detect B-actin mRNA in pancreas tissue may be caused by either low expression of this mRNA or unsuccessful isolation of RNA due to a high concentration of RNases in this organ.

The expression of early R44 as well as late R32 mRNA was detected in the salivary glands, spleen, lungs and PBL at day 7 pi (Fig. 7). In addition, R44 mRNA was found in liver, heart, brain and bone marrow. Nevertheless, infectious virus was not isolated from any of these organs at 7 days pi, either in experiment II or I (Fig. 2). Interestingly, IE-1 mRNA could not be detected in all organs that were positive for R32 and/or R44 mRNA. More specifically, the detection of IE-1 mRNA was limited to the salivary glands and lungs. Since infectious virus is usually isolated from the salivary glands from day $10 \mathrm{pi}$ (11), the detection of IE-1 mRNA early after primary infection of immunocompetent rats appears to 
have a higher positive predictive value for the onset of a productive infection than the detection of R44 or R32 mRNA.

At 120 days pi in experiment II, viral DNA was found in the salivary glands, spleen, liver, lungs, pancreas, blood plasma, PBL, brain and left carotid artery (Fig. 6). For most of these organs, only one of the five rats was RCMV DNA-positive. Only two organs were found positive in at least two rats. Furthermore, each infected rat contained at least one RCMV DNA-positive organ, with a maximum of five (data not shown). The salivary glands appeared to be the site of persistent infection, since it was found to contain RCMV DNA and infectious virus in 5 out of 5 and 4 out of 5 rats in experiment I and II, respectively (Fig. 6). The presence of DNA in the salivary glands of one animal could not be determined due to the presence of PCR inhibitors. However, viral DNA was also undetectable in other organs of this rat. Moreover, infectious virus could not be isolated from the salivary glands of this rat, whereas for the other rats these glands were found to contain relatively high titers of virus (median $=6.8 \times 10^{3} \mathrm{PFU} / \mathrm{ml}$ ). Therefore, it is most likely that the viral DNAnegative rat had not been successfully infected with RCMV.

All tissues and organs obtained from 2 selected rats at day 120 pi were subjected to the different RT-PCR assays. IE-1, R32 as well as R44 mRNA were found in the salivary glands, but not in any other organ (data not shown). Identical results were obtained after further

a experiment $1 \square$ experiment 2

day 120 p.i.

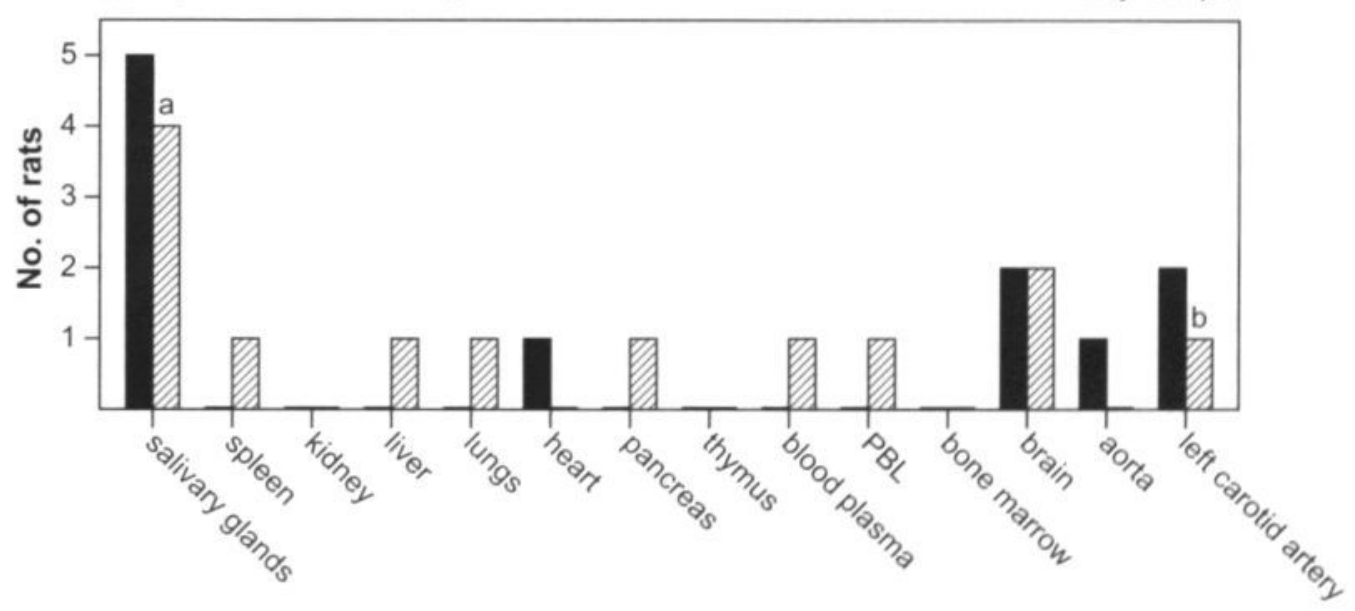

FIG. 6. RCMV DNA detection by PCR in various rat organs and tissues at 120 days pi, in experiment I and II. The number of rats that were RCMV DNA-positive for one specific organ is indicated by black and hatched bars, representing experiment I and II, respectively. $a$ and $b$ indicate that for one sample an invalid PCR result was obtained due to the inability to amplify the spike of control DNA added to the PCR reaction. 
- DNA $\square$ actin $\quad \mathbb{R}$ R32 $\square$ R44 $\mathbb{Q}$ IE-1
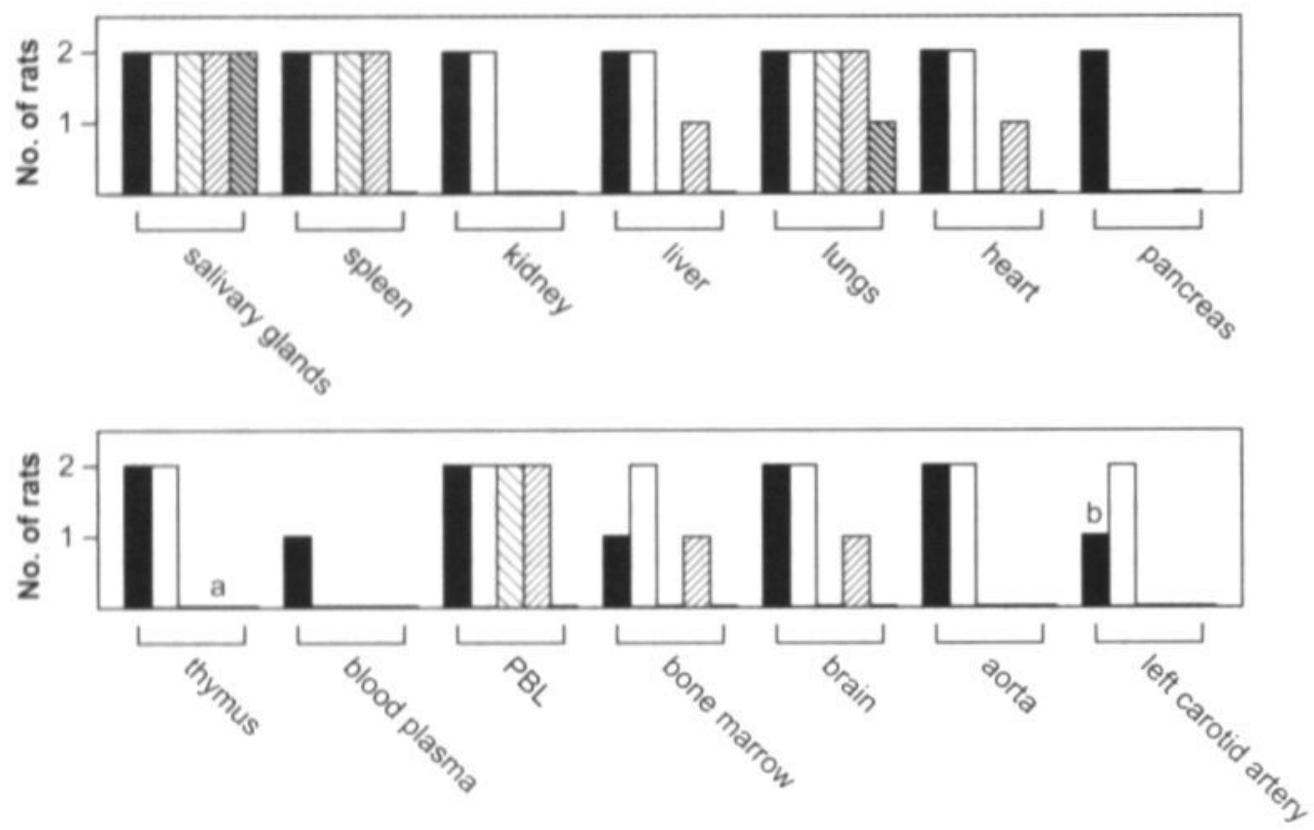

FIG. 7. Detection of RCMV DNA and mRNA in various organs and tissues obtained from two RCMV-infected rats at 7 days pi. The number of DNA- or mRNA-positive rats is indicated by differently hatched bars. $a$ and $b$ indicate that for one sample an invalid (RT-)PCR result was obtained due to the inability to amplify the spike of control RNA or DNA added to the (RT-)PCR reaction.

analysis of viral mRNA expression in viral DNA-positive organs from the other 3 animals. Taken together, our data show that, in contrast to other organs and tissues, the salivary glands contain a high load of replicating virus at 120 days pi. This situation is similar to that in immunocompromised, RCMV-infected rats at several months pi $(13,14)$. Apparantly, differences in the course of RCMV infection between immunocompetent and immunocompromised rats exist mainly during the first weeks after infection. This can be explained by the fact that rats are immunosuppressed by a single treatment with gamma irradiation before infection. After infection with a sublethal dose of RCMV, the immunocompromised rats will usually recover and develop a similar antiviral immune response as do immunocompetent rats $(60)$. Thus the status of the infection may be similar in immunocompetent and irradiated rats, after the immune system of the irradiated rats has fully recovered. 
Detection of an antisense transcript of the RCMV major IE region. In RCMV-infected rats, IE-1 mRNA was not frequently detected and its expression appears to be mainly restricted to organs in which infectious virus can also be detected, in particular the salivary glands. Interestingly, the IE-1 RT-PCR on total RNA from PBL, harvested 7 days pi, resulted in the amplification of a fragment of which the length, $292 \mathrm{bp}$, corresponds with that of a fragment that would be generated by amplification of either genomic RCMV DNA or unspliced IE-1 mRNA (Fig. 8, lane 2). Since the amplification of this fragment was dependent on the use of RT, it is not likely that it was generated by amplification of genomic DNA. Similar fragments were observed in the salivary glands of rats sacrificed at 7 and 120 days pi, and also in vitro, in RCMV-infected REF at 48 hours pi. (Fig. 8, lane 8 and 14 , respectively). We further investigated the structure of this transcript by performing strand-specific RT-PCR reactions in order to determine the sense or antisense orientation of the mRNA. To this purpose, one of the primers of the RT-PCR primer set was omitted from the reaction during the conversion of mRNA to CDNA. The omitted primer was subsequently added after the inactivation of RT and activation of the HotstarTaq polymerase for $15 \mathrm{~min}$ at $95^{\circ} \mathrm{C}$. Using this procedure, reverse transcription in the presence of primer RT-IE1-F2, resulted for salivary glands and REF in the amplification of a 195-bp fragment that was derived from the spliced, sense IE-1 transcript (Fig. 8, lane 12 and 18). Reverse transcription in the presence of RT-IE1-B2, resulted for PBL, salivary glands and REF in the amplification of a 292-bp product that was derived from an antisense, unspliced mRNA (Fig. 8, lane 4, 10 and 16). The observed fragments with a size other than 195-bp or 292-bp, are the result of amplification mediated by outer and inner primer pair combinations. From these results we conclude that the 292-bp fragment is derived from an unspliced antisense transcript of the MIE region. This antisense, unspliced mRNA will be further referred to as IE-AS. Interestingly, IE-AS was detected in blood leukocytes in the absence of IE-1 mRNA (Fig. 8, compare lane 4 to lane 6). This suggested that the expression of IE-AS may be involved in downregulation of IE-1 synthesis. On the other hand, in the salivary glands and in REF, IE-AS and IE-1 could be detected simultaneously. Furthermore, IE-AS expression was not found in all tissues and organs in which IE-1 mRNA expression appeared to be absent.

By Northern blot analysis, IE-AS could not be detected in RCMV-infected REF at either IE, early or late times of infection (data not shown). We therefore conclude that IE-AS is only expressed at low levels. As an alternative to Northern analysis, limited dilution RTPCR was performed on IE-AS, using total RNA isolates from RCMV-infected REF at IE, early or late times of infection. Surprisingly, IE-AS was found in each phase of infection at approximately similar levels (data not shown). Thus, in contrast to IE-1, which was 
Strand-specific detection of IE-1 and IE-AS mRNA in

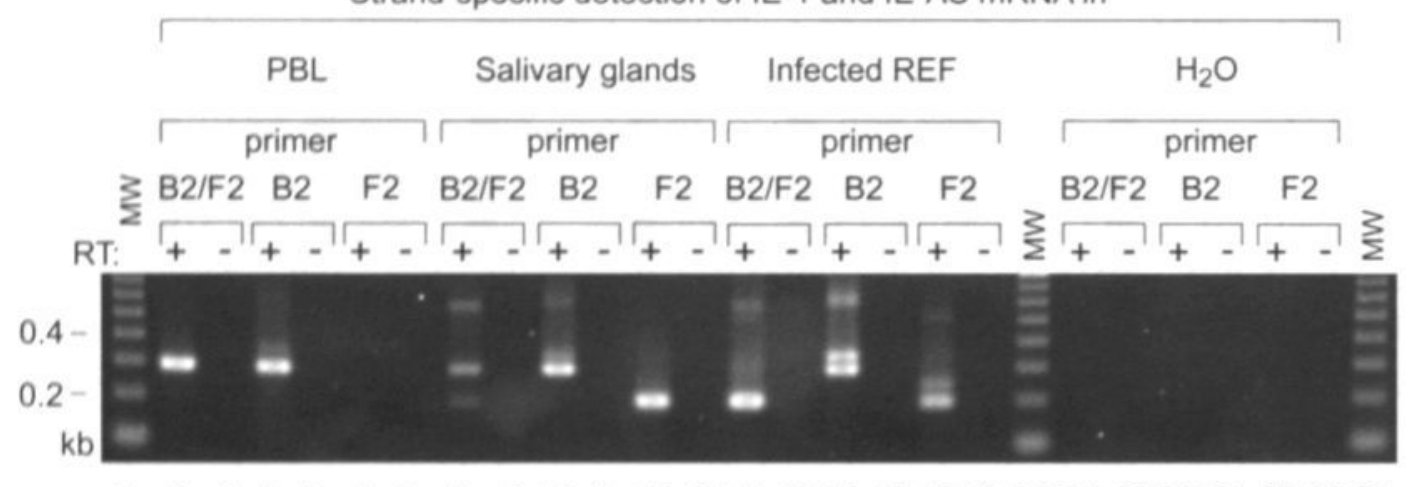

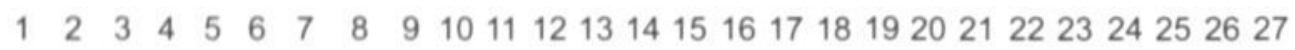

FIG. 8. Identification of an antisense transcript in the RCMV MIE region. Primers from the IE-1 RT-PCR assay were used for (strand-specific) amplification on total RNA isolated from peripheral blood leukocytes (PBL, lane 2-7), salivary glands at 120 days pi (lane 8-13) and RCMV-infected REF at 48 hours pi (lane 14-19). Water was also used as input for RT-PCR and served as a negative control (lane 21-26). Molecular weight (MW) size markers are indicated on the left side of the panel (lane 1) and in two lanes (20 and 27) on the right side of the panel. Initially, the original protocol for single-tube IE-1 RT-PCR was performed with the primers RT-IE1-B2 and RT-IE1-F2 (Table 1, Fig. 9). These primers were simultaneously present during the reverse transcription step at $55^{\circ} \mathrm{C}$, in the presence (+; lane $2,8,14$, and 21) or absence (-; lane 3, 9, 15, and 22) of reverse transcriptase (RT). The expected size for amplification of sense, spliced IE-1 CDNA is $195 \mathrm{bp}$, whereas for cDNA generated from antisense, unspliced mRNA this is $292 \mathrm{bp}$. For the strand-specific detection of sense IE-1 mRNA in PBL (lane 6), salivary glands (lane 12), REF (lane 18) and water (lane 25), the primer RT-IE1$B 2$ was omitted from the reaction mixture during the reverse transcription step, but was subsequently added after inactivation of $R T\left(15 \mathrm{~min}\right.$ at $\left.95^{\circ} \mathrm{C}\right)$, prior to $P C R$. Control reactions in the absence of $R T$ were included (-; lane 7, 13, 19, and 26). For the strand-specific detection of antisense $m R N A$ in PBL (lane 4), salivary glands (lane 10), REF (lane 16) and water (lane 23), the primer RT-IE1-F2 was omitted from the reaction mixture during the reverse transcription step, but was subsequently added after inactivation of RT, prior to PCR. Control reactions in the absence of $R T$ were included (-; lane $5,11,17,24)$.

exclusively detected during the IE phase of infection (5), expression of IE-AS does not seem to be restricted to either the IE, early or late phase of infection in vitro.

The structure of the RCMV IE-AS transcript. In order to elucidate the structure of the novel IE-AS transcript, we amplified its $5^{\prime}$ and $3^{\prime}$ ends by RACE. Two major fragments of approximately 1,100 and 570 bp were amplified by 5' RACE (data not shown). These fragments were cloned and sequenced. For the largest $5^{\prime}$ RACE product 4 independent clones were obtained with identical 5' ends (5'-GGGGCCGTGAGGGTGACC-3'; in which the $5^{\prime}$ terminal G residue corresponds to position 172,229 of the RCMV genomic sequence). This transcription start site is localized within exon 4 of the MIE region (Fig. 9). The exact 5 '-terminal nucleotide could not be determined since a stretch of C-residues was added to 
the first strand CDNA in the 5' RACE procedure. As a consequence, each of the nucleotides in italics may represent the actual $5^{\prime}$ end of the IE-AS mRNA. For the smaller 5' RACE product, 3 independent clones were obtained with identical $5^{\prime}$ ends ( $5^{\prime}$ ACCTGATCCTGTTTCCACC-3'; in which the 5'-terminal A residue corresponds to position 172,772 of the RCMV genomic sequence). This $5^{\prime}$ end is also located within exon 4 of the MIE region, 543 bp downstream of the first transcription start site.

To determine the 3 ' end of the IE-AS transcripts, $3^{\prime}$ RACE was performed. The primers that were selected for the $3^{\prime}$ RACE would result in a PCR fragment that partially overlaps the $5^{\prime}$ RACE products. Amplification using these primers generated one major fragment of approximately $400 \mathrm{bp}$ (data not shown), which was cloned. Two independent clones were sequenced and found to differ only 8 nucleotides in length. Both 3 '-terminal sequences, 5 'AAAATAAAAATGTCCCACCTTAAA-3' and 5'-AAAATAAAAATGTCCCACCTTTTTATGTT $A A A-3^{\prime}$, contain a consensus polyadenylation site (underlined) and a polyA stretch (in italics). The 3'- terminal T residues of the transcripts correspond to position 173,622 and 173,630 , respectively, of the RCMV genomic sequence, and are both localized within intron 2 of the MIE region (Fig. 9). Thus, it can be concluded that at least two different major IEAS transcripts exist, IE-AS1 and IE-AS2, with a length of approximately $0.86 \mathrm{~kb}$ and $1.4 \mathrm{~kb}$, respectively.

The transcription of antisense mRNA from the MIE region has also been reported for HCMV in granulocyte-macrophage progenitor cells and in the bone marrow of healthy seropositive individuals (34). The transcription start site of the HCMV antisense transcript was found to be situated within exon 4 of the IE- 1 transcript, at a position that corresponds with the start site of RCMV IE-AS2 (Fig. 9). A second, downstream start site for the HCMV antisense transcript has not been reported. In analogy to what has been described for the HCMV antisense transcript, sequence analysis of the region upstream of the two start sites of the RCMV IE-AS1 and IE-AS2 transcripts showed that a consensus TATA element is lacking. Thus, the sequence upstream of the IE-AS transcription start sites is likely to possess alternative signals governing transcription initiation.

Sequence analysis of the HCMV antisense transcript revealed the presence of six open reading frames (ORFs) greater than 30 codons (Fig. 9). The RCMV IE-AS1 and IE-AS2 were found to harbor only one and two of such ORFs, respectively. These ORFs, ORF58 and ORF45, have the potential to encode small proteins with a predicted molecular mass of 6.4 and $5.0 \mathrm{kDa}$, respectively. Interestingly, the $3^{\prime}$ end of the HCMV antisense trancript was found to be localized in intron 1 of the IE- 1 transcript, whereas the RCMV IE-AS transcripts both terminated within intron 2. As a consequence, the RCMV IE-AS transcripts do not encode putative homologs of the proteins encoded by HCMV ORF152, ORF35 and ORF50. 


\section{CHAPTER 5}

\section{HCMV}

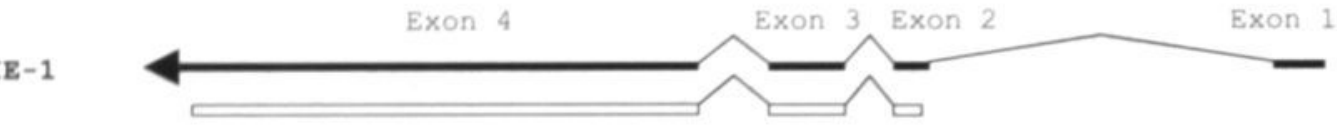

Antisense CLT

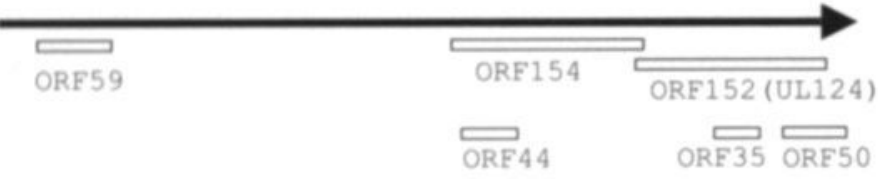

\section{$\underline{R C M V}$}

IE-AS1

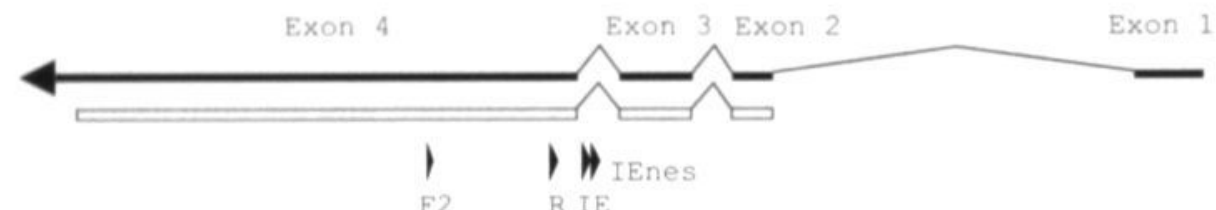

F2

RIE

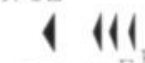

3 F2 3AF

IE-AS2

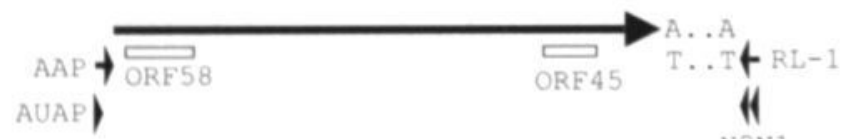

N2N1

\begin{tabular}{|c|c|c|}
\hline $\begin{array}{l}\text { Gene-specific } \\
\text { primers }\end{array}$ & Sequence $\left(5^{\prime}-3^{\prime}\right)$ & $\begin{array}{l}\text { osition primers in } \\
\text { MV genomic sequence }\end{array}$ \\
\hline $\mathrm{RT}-\mathrm{IE} 1-\mathbf{B} 2$ & AACCCAGACCACCGAAC & $173,497-173,513^{b}$ \\
\hline IE $1-\mathrm{NRT}-\mathbf{F}$ & TTCTAACCGATCCAGAACCA & $173,447-173,466^{b}$ \\
\hline 3A & CCTATGATCGAAGCCATGGACAC & $173,406-173,428^{b}$ \\
\hline $3 F 2$ & AGGGGGTGGTAAACAAGAGGCAATAAGCAA & $173,278-173,307^{b}$ \\
\hline $\mathrm{RT}-\mathrm{IE} 1-\mathbf{F} \mathbf{2}$ & сTCTCTGTGCGGCTTC & $172,857-172,872$ \\
\hline IE1-NRT-R & GCGAATCTCATCACCATTTC & $173,174-173,193$ \\
\hline pint $3-\mathbf{I E}$ & CTGTAAACCATAGATAGAGGCAAAG & $173,253-173,277$ \\
\hline Plint 3-IEnes & CAGTAAGCTTTTGCTTATTGCCTCTTGTTTACCAC & $173,278-173,302$ \\
\hline RACE-primers & Sequence $\left(5^{\prime}-3^{\prime}\right)$ & \\
\hline 31RACE-RL-1 & \multirow{2}{*}{\multicolumn{2}{|c|}{$\begin{array}{l}\text { CCTATGATATTTCTTCCAGGGTAAAGCTTGGGTAGTCCCCACCTTCTGCAG (T) } 17 \\
\text { CCTATGATATTTCTTCCAGGGTAAAGCTT }\end{array}$}} \\
\hline 3\RACE-N1 & & \\
\hline 31 RACE-N2 & \multicolumn{2}{|l|}{ GGGTAGTCCCCACCTTCTGCAG } \\
\hline 5IRACE- AAP & \multicolumn{2}{|l|}{ GGCCACGCGTCGACTAGTACGGGIIGGGIIGGGIIG } \\
\hline AUAP & \multicolumn{2}{|l|}{ GGCCACGCGTCGACTAGTAC } \\
\hline
\end{tabular}


\&IG. 9. Schematic representation of RCMV and HCMV (AD169) MIE sense and antisense transcripts. The transcripts are indicated by black arrows. Their orientation is drawn relative to the genomic sequence. Open reading frames (ORFs) greater than 30 codons are indicated by open bars below the transcripts. The number of codons contained within each ORF is indicated by a number, i.e. ORF154 contains 154 codons. The position of the primers used in this study for RT-PCR and RACE procedures is indicated by black triangles. The sequences of the primers are shown below the maps. a. The RCMV DNA sequences are derived from Vink et al. (61). The primer sequences indicated by $b$ are complementary to the published RCMV genomic sequence. CLT, HCMV latency associated transcript (34); IE-AS, immediate carly-antisense transcript.

Based on position and size, the RCMV ORF58 and HCMV ORF59, as well as the RCMV ORF45 and HCMV ORF44 appear to be conserved. However, the sequence homology between the proteins predicted to be encoded by the corresponding HCMV and RCMV ORFs is very low (data not shown). Further studies on the expression of the IE-AS transcripts and their putative gene products may lead to a better understanding of the regulation of RCMV MIE gene expression.

\section{DISCUSSION}

We investigated the dissemination of RCMV after primary infection of immunocompetent Wistar rats, using PCR and RT-PCR assays for the sensitive detection of RCMV DNA and mRNA, respectively. In addition, the production of infectious virus was determined by plaque assay. We found that RCMV DNA was readily detected in most organs during the first week pi. However, the presence of infectious virus in this period was limited to the bone marrow, spleen and kidney. In a previous study with immunocompetent Brown Norway $(\mathrm{BN})$ rats, infectious RCMV was not only detected in these organs in the first week pi, but also in heart, thymus, and PBL, albeit at low titers (11). It is highly likely that the differences between these data and the results from the present study are the consequence of using different rat strains. In analogy, it was found for murine CMV (MCMV) that the susceptibility for infection can vary considerably between different strains of mice $(2,21,42,52)$.

The inability to detect infectious RCMV in the majority of organs or blood cells during acute infection, indicated either that infectious virus was not produced at all or that the amount of infectious virus was below the detection level of the plaque assay. Nevertheless, the findings from this study on RCMV infection of immunocompetent rats are in striking contrast with previous studies in immunocompromised rats. Infections in those rats with similar doses of RCMV as used in this study usually result in high titers of infectious virus $(48,55)$. Therefore, this study emphasizes once again the crucial role of a fully functional immune system in controlling CMV infections. 
Analysis of IE, early and late mRNA expression was performed to investigate the viral activity at 7 days pi in more detail. Late R32 mRNA could be detected in blood cells, salivary glands, spleen, and lungs at 7 days pi, although infectious virus was not isolated from any of these organs. This showed that the presence of late RCMV mRNA is not necessarily correlated with the production of detectable amounts of infectious virus. In liver, heart, bone marrow and brain, early R44 mRNA was detected in the absence of both late mRNA expression and production of infectious virus. Thus, full replication of RCMV leading to production of infectious virus may be arrested after either early or late mRNA expression. This notion is supported by recent studies on MCMV infections, in which it was found that the viral replication cycle can be blocked at several checkpoints on the way from latency to complete reactivation $(36,37)$.

With respect to the possible existence of checkpoints in the replication cycle of RCMV, the general absence of RCMV IE-1 mRNA at 7 days pi, in particular in those organs in which early and late mRNA are detected, is intriguing. In contrast to RCMV IE-1 transcripts, MCMV IE-1 mRNA can be detected in various organs during primary infection of mice $(9,33,64)$. However, there are clear differences between MCMV infections and RCMV infections in vivo. In contrast to RCMV infections of immunocompetent rats, infection of immunocompetent mice with MCMV leads to replication of virus to high titers in various tissues and blood $(2,43,56,65)$. Moreover, a high dose of virus inocculated in susceptible strains of immunocompetent mice can be lethal $(1,24)$, whereas RCMV infections in immunocompetent rats is not lethal, even when a high dose of virus is used (10, 11, 55). Similarly, HCMV infections in healthy individuals usually remain asymptomatic. Unfortunately, due to the limited availability of human tissue or blood samples, little is known about the production of infectious HCMV and viral mRNA during the acute phase of primary infections in healthy individuals.

In addition to the general absence of RCMV IE-1 mRNA expression at 7 days pi, this transcript was also undetectable in all organs at 120 days pi, except in the salivary glands. Also, early and late mRNA as well as infectious virus could only be detected in the salivary glands at 120 days pi. Thus, infection of the salivary glands can be characterized as a persistent infection rather than a latent infection at this time-point.

The inability to detect IE-1 mRNA in organs other than the salivary glands at 120 days pi is in agreement with data from previous studies which reported that the expression of the MCMV IE-1 gene could not be detected during latent MCMV infection in various organs, including spleen, lungs and blood $(9,33,45,65)$. Expression of HCMV IE-1 mRNA was also not found in blood cells during latent infection in healthy seropositive individuals $(25,59)$. On the contrary, several authors reported the detection of MCMV IE-1 mRNA in 
latently infected spleen and lungs $(29,36,64,65)$. It was proposed that during latent infection of the lungs, MCMV IE-1 transcripts are produced in a random, focal fashion, but this expression does not necessarily lead to the production of infectious virus $(26,36,37)$.

RCMV IE-1 mRNA expression was found to be strongly correlated with production of infectious virus, since it was mainly detected during persistent infection in the salivary glands at 120 days pi, and during productive in vitro infection of REF. IE-1 mRNA was also detected in the salivary glands and lungs at 7 days pi in the absence of infectious virus. However, previous studies have shown that RCMV can be isolated from salivary glands as early as 10 days pi (11). Thus, the expression of RCMV IE-1 has a high positive predictive value for the onset of production of infectious virus. The absence of detectable levels of the RCVM IE-1 transcript during acute and latent infection in most organs suggests that the IE1 expression is significantly repressed in immunocompetent rats.

At 120 days pi, infectious virus was only detected in the salivary glands. This is in agreement with previous studies with $\mathrm{BN}$ and Lewis rats $(11,12)$. In addition, similar findings were reported for MCMV infection in mice $(3,53)$. It has previously been shown that the rat salivary glands are not subject to natural killer cell surveillance (60). Consequently, RCMV may persist in this organ for at least several months. Nevertheless, the salivary glands are not the only organs that harbour RCMV at 120 days pi, as indicated by the occasional presence of RCMV DNA in other organs.

It was reported for both HCMV and MCMV, that blood monocytes are a predominant site for latent infection $(33,49,57,58)$. Moreover, it was suggested that the bone marrow, which harbors the progenitor cells of monocytes, acts as a reservoir from which CMV can be transmitted $(40,44,65,66)$. However, RCMV DNA was not detected in bone marrow 120 days after infection, and detection of RCMV DNA in blood was restricted to a single rat at that time-point. In agreement with these data, it was previously shown that blood leukocytes from latently infected donor rats were not capable of transferring RCMV to a seronegative immunocompromised recipient (13). Therefore, bone marrow and blood cells do not appear to be a major site of latent RCMV infection. Similarly, MCMV was found to be cleared from bone marrow and blood several months after infection $(3,4,21)$. Conversely, latent MCMV DNA was detected in various other organs of mice (19, 21, 32, 43, 63). The preferred sites for latent MCMV infection were reported to be spleen and, in particular, lungs $(4,43,50)$. The lungs were found to contain a 10 -fold higher viral DNA load than the spleen during latency (4). In the present study, RCMV DNA was detected in spleen and lungs, as well as in other organs at 120 days pi. The presence of RCMV in various organs during latent infection is probably explained by the fact that the virus is present in similar cell types in different organs. This theory is supported by the fact that 
latent HCMV and MCMV have been detected in vascular cells and tissue macrophages of various organs $(23,28,32,33,50)$. In conclusion, RCMV can reside in many different rat organs during latent infection. It is important to note, however, that at 120 days pi, virus is still produced in the salivary glands. Thus, although RCMV latency may have been established locally at various sites within the infected rats, viral latency at the level of the whole organism has not yet been set in at 120 days pi. In fact, it was previously found that infectious virus can be detected in salivary glands for up to 7 months pi in BN rats, whereas for Lewis rats this can be up to at least 1 year pi (10).

An interesting aspect with regard to the regulation of RCMV gene expression is the identification of novel unspliced transcripts that are derived from the RCMV MIE region and that are complementary to part of the IE-1 transcript. These antisense transcripts (IEAS1 and IE-AS2) were initially detected at 7 days pi in PBL in the absence of IE- 1 mRNA expression. This suggested that the antisense transcripts might be involved in downregulation of IE-1 transcription. However, in the salivary glands and during in vitro infection, IE-1 and IE-AS transcripts could be detected simultaneously. Furthermore, the IEAS transcripts could not be detected in every organ in which IE-1 mRNA was absent.

For HCMV, transcription of a similar antisense transcript from the MIE region was detected in granulocyte-macrophage progenitor cells and in bone marrow of healthy seropositive individuals in the absence of transcripts that are generated during productive infection. Therefore, the antisense transcript was designated as a CMV latency-associated transcript (CLT, 34). In addition, sense CLTs were found with transcription start sites in the HCMV MIE promoter-enhancer region, upstream of the start site from which IE-1 and IE2 mRNA are transcribed. Nevertheless, the sense CLTs were recently also shown to be expressed in a variety of HCMV-infected cell types, including human fibroblasts, during productive infection in vitro (39). Similar findings for the HCMV antisense CLT have hitherto not been reported.

The HCMV antisense CLT was found to contain six ORFs greater than 30 codons (Fig. 9). The function of the HCMV CLTs and/or their encoded proteins is still unclear (62). Nevertheless, putative homologs of the largest proteins encoded by the HCMV antisense CLT, ORF154 and ORF152, are not encoded by the RCMV IE-AS transcripts. Instead, two small ORFs, ORF58 and ORF45, were found to have a similar position as well as orientation as HCMV ORF59 and ORF44, respectively (Fig. 9). The corresponding HCMV and RCMV proteins encoded by these ORFs, however, show only limited similarity (data not shown). Antibodies directed against HCMV antisense CLT-encoded proteins ORF59, ORF154 as well as ORF152 were found in the serum of healthy seropositive individuals and patients with active CMV infection, which indicates that these proteins are expressed in vivo 
$(34,38)$. Since similar analysis for the HCMV antisense CLT-encoded protein ORF44 was not performed, it is still unknown whether this protein is expressed in vivo.

Although the RCMV IE-AS transcripts may indeed encode functional proteins, it is also possible that they play a role in the regulation of gene expression by the formation of double stranded (ds) RNA with the complementary, sense transcript. In fact, the formation of dsRNA is recently being recognized as an important mechanism in post-transcriptional gene silencing in higher eukaryotes $(27,35,54)$. A role for antisense transcripts in the regulation of herpesvirus gene expression, inhibition of viral replication, and establishment of latent infection, has been suggested for herpes simplex virus type-1 (18, 22, 41), Epstein Barr virus (51) as well as Marek's disease virus $(16,17)$. Nevertheless, no direct evidence for the existence of dsRNA formation during herpesvirus infection has yet been reported. Clearly, the subject of future studies will be the elucidation of the function of the RCMV IEAS transcripts during RCMV infections in vitro and in vivo.

\section{ACKNOWLEDGMENTS}

We thank Monique Coomans, Martine Hulsbosch, Joanne van Dam, Marjorie Nelissen for their excellent technical assistance and Patrick Beisser and Koen van Cleef for critical reading of the manuscript. The research of Dr. C. Vink has been made possible by a fellowship of the Royal Netherlands Academy of Arts and Sciences. 


\section{REFERENCES}

1. Allan, J. E., and G. R. Shellam. 1984. Genetic control of murine cytomegalovirus infection: virus titres in resistant and susceptible strains of mice. Arch. Virol. 81:139-150.

2. Bale, J. F., Jr., and M. E. O'Neil. 1989. Detection of murine cytomegalovirus DNA in circulating leukocytes harvested during acute infection of mice. J. Virol. 63:2667-2673.

3. Balthesen, M., L. Dreher, P. Lucin, and M. J. Reddehase. 1994. The establishment of cytomegalovirus latency in organs is not linked to local virus production during primary infection. J. Gen. Virol. 75:2329-2336.

4. Balthesen, M., M. Messerle, and M. J. Reddehase. 1993. Lungs are a major organ site of cytomegalovirus latency and recurrence. J. Virol. 67:5360-5366.

5. Beisser, P. S., S. J. Kaptein, E. Beuken, C. A. Bruggeman, and C. Vink. 1998. The Maastricht strain and England strain of rat cytomegalovirus represent different betaherpesvirus species rather than strains. Virology. 246:341-351.

6. Beisser, P. S., J. S. Kloover, G. E. Grauls, M. J. Blok, C. A. Bruggeman, and C. Vink. 2000. The r144 major histocompatibility complex class I-like gene of rat cytomegalovirus is dispensable for both acute and long-term infection in the immunocompromised host. J. Virol. 74:1045-1050.

7. Beisser, P. S., C. Vink, J. G. Van Dam, G. Grauls, S. J. Vanherle, and C. A. Bruggeman. 1998. The R33 G protein-coupled receptor gene of rat cytomegalovirus plays an essential role in the pathogenesis of viral infection. J. Virol. 72:2352-2363.

8. Beuken, E., G. Grauls, C. A. Bruggeman, and C. Vink. 1999. The rat cytomegalovirus R32 gene encodes a virion-associated protein that elicits a strong humoral immune response in infected rats. J. Gen. Virol. 80:2719-2728.

9. Bevan, I. S., C. C. Sammons, and C. Sweet. 1996. Investigation of murine cytomegalovirus latency and reactivation in mice using viral mutants and the polymerase chain reaction. J. Med. Virol. 48:308-320.

10. Bruggeman, C. A., W. M. Debie, G. Grauls, G. Majoor, and C. P. van Boven. 1983. Infection of laboratory rats with a new cytomegalo-like virus. Arch. Virol. 76:189-199.

11. Bruggeman, C. A., H. Meijer, F. Bosman, and C. P. van Boven. 1985. Biology of rat cytomegalovirus infection. Intervirology. 24:1-9.

12. Bruggeman, C. A., H. Meijer, P. H. Dormans, W. M. Debie, G. E. Grauls, and C. P. van Boven. 1982. Isolation of a cytomegalovirus-like agent from wild rats. Arch. Virol. 73:231-241.

13. Bruning, J. H., C. A. Bruggeman, C. P. van Boven, and P. J. van Breda Vriesman. 1986. Passive transfer of cytomegalovirus by cardiac and renal organ transplants in a rat model. Transplantation. 41:695-698.

14. Bruning, J. H., C. A. Bruggeman, and P. J. van Breda Vriesman. 1988. The transfer of cytomegalovirus infection in rats by latently infected renal allografts, and the role of various immunosuppressive regimens in virus reactivation. Transplantation. 46:623-624.

15. Bruning, J. H., C. A. Bruggeman, and P. J. van Breda Vriesman. 1989. Transfer of cytomegalovirus infection via renal allografts: role of immunosuppressive regimens on the transfer rate, and effect of cytomegalovirus infections on renal allograft rejection; study in a rat model. Transplant. Proc. 21:2089-2090. 
16. Cantello, J. L., A. S. Anderson, and R. W. Morgan. 1994. Identification of latency-associated transcripts that map antisense to the ICP4 homolog gene of Marek's disease virus. J. Virol. 68:6280-6290.

17. Cantello, J. L., M. S. Parcells, A. S. Anderson, and R. W. Morgan. 1997. Marek's disease virus latency-associated transcripts belong to a family of spliced RNAs that are antisense to the ICP4 homolog gene. J. Virol. 71:1353-1361.

18. Carter, K. L., P. L. Ward, and B. Roizman. 1996. Characterization of the products of the U(L) 43 gene of herpes simplex virus 1: potential implications for regulation of gene expression by antisense transcription. J. Virol. 70:7663-7668.

19. Cheung, K. S., and D. J. Lang. 1977. Detection of latent cytomegalovirus in murine salivary and prostate explant cultures and cells. Infect. Immun. 15:568-574.

20. Chomczynski, P., and N. Sacchi. 1987. Single-step method of RNA isolation by acid guanidinium thiocyanate-phenol-chloroform extraction. Anal. Biochem. 162:156-159.

21. Collins, T., C. Pomeroy, and M. C. Jordan. 1993. Detection of latent cytomegalovirus DNA in diverse organs of mice. J. Infect. Dis. 168:725-729.

22. Cook, W. J., K. K. Wobbe, J. Boni, and D. M. Coen. 1996. Regulation of neighboring gene expression by the herpes simplex virus type 1 thymidine kinase gene. Virology. 218:193-203.

23. Fish, K. N., C. Söderberg-Nauclér, L. K. Mills, S. Stenglein, and J. A. Nelson. 1998. Human cytomegalovirus persistently infects aortic endothelial cells. J. Virol. 72:5661-5668.

24. Furrarah, A. M., and C. Sweet. 1994. Studies of the pathogenesis of wild-type virus and six temperature-sensitive mutants of mouse cytomegalovirus. J. Med. Virol. 43:317-330.

25. Gerna, G., F. Baldanti, D. Lilleri, M. Parea, E. Alessandrino, A. Pagani, F. Locatelli, J. Middeldorp, and M. G. Revello. 2000. Human cytomegalovirus immediate-early mRNA detection by nucleic acid sequence-based amplification as a new parameter for preemptive therapy in bone marrow transplant recipients. J. Clin. Microbiol. 38:1845-1853.

26. Grzimek, N. K., D. Dreis, S. Schmalz, and M. J. Reddehase. 2001. Random, asynchronous, and asymmetric transcriptional activity of enhancer-flanking major immediate-early genes ie1/3 and ie2 during murine cytomegalovirus latency in the lungs. J. Virol. 75:2692-2705.

27. Hammond, S. M., A. A. Caudy, and G. J. Hannon. 2001. Post-transcriptional gene silencing by double-stranded RNA. Nat. Rev. Genet. 2:110-119.

28. Hendrix, M. G., M. Daemen, and C. A. Bruggeman. 1991. Cytomegalovirus nucleic acid distribution within the human vascular tree. Am. J. Pathol. 138:563-567.

29. Henry, S. C., and J. D. Hamilton. 1993. Detection of murine cytomegalovirus immediate early 1 transcripts in the spleens of latently infected mice. J. Infect. Dis. 167:950-954.

30. Ho, M. 1990. Epidemiology of cytomegalovirus infections. Rev. Infect. Dis. 12 Suppl. 7:S701-710.

31. Kaptein, S. J. F., E. Beuken, G. E. L. M. Grauls, C. A. Bruggeman, and C. Vink. 2001. Rat cytomegalovirus open reading frame R44 is an early-late gene that encodes a nuclear protein. Arch. Virol. in press.

32. Klotman, M. E., S. C. Henry, R. C. Greene, P. C. Brazy, P. E. Klotman, and J. D. Hamilton. 1990. Detection of mouse cytomegalovirus nucleic acid in latently infected mice by in vitro enzymatic amplification. J. Infect. Dis. 161:220-225.

33. Koffron, A. J., M. Hummel, B. K. Patterson, S. Yan, D. B. Kaufman, J. P. Fryer, F. P. Stuart, and M. I. Abecassis. 1998. Cellular localization of latent murine cytomegalovirus. J. Virol. 72:95-103. 
34. Kondo, K., J. Xu, and E. S. Mocarski. 1996. Human cytomegalovirus latent gene expression in granulocyte-macrophage progenitors in culture and in seropositive individuals. Proc. Natl. Acad. Sci. USA. 93:11137-11142.

35. Kumar, M., and G. G. Carmichael. 1998. Antisense RNA: function and fate of duplex RNA in cells of higher eukaryotes. Microbiol. Mol. Biol. Rev. 62:1415-1434.

36. Kurz, S. K., M. Rapp, H. P. Steffens, N. K. Grzimek, S. Schmalz, and M. J. Reddehase. 1999. Focal transcriptional activity of murine cytomegalovirus during latency in the lungs. J. Virol. 73:482-494.

37. Kurz, S. K., and M. J. Reddehase. 1999. Patchwork pattern of transcriptional reactivation in the lungs indicates sequential checkpoints in the transition from murine cytomegalovirus latency to recurrence. J. Virol. 73:8612-8622.

38. Landini, M. P., T. Lazzarotto, J. Xu, A. P. Geballe, and E. S. Mocarski. 2000. Humoral immune response to proteins of human cytomegalovirus latency-associated transcripts. Biol. Blood Marrow Transplant. 6:100-108.

39. Lunetta, J. M., and J. A. Wiedeman. 2000. Latency-associated sense transcripts are expressed during in vitro human cytomegalovirus productive infection. Virology. 278:467-476.

40. Maciejewski, J. P., E. E. Bruening, R. E. Donahue, E. S. Mocarski, N. S. Young, and S. C. St Jeor. 1992. Infection of hematopoietic progenitor cells by human cytomegalovirus. Blood. 80:170-178.

41. Mador, N., D. Goldenberg, O. Cohen, A. Panet, and I. Steiner. 1998. Herpes simplex virus type 1 latency-associated transcripts suppress viral replication and reduce immediate-early gene mRNA levels in a neuronal cell line. J. Virol. 72:5067-5075.

42. Mercer, J. A., and D. H. Spector. 1986. Pathogenesis of acute murine cytomegalovirus infection in resistant and susceptible strains of mice. J. Virol. 57:497-504.

43. Mercer, J. A., C. A. Wiley, and D. H. Spector. 1988. Pathogenesis of murine cytomegalovirus infection: identification of infected cells in the spleen during acute and latent infections. J. Virol. 62:987-997.

44. Minton, E. J., C. Tysoe, J. H. Sinclair, and J. G. Sissons. 1994. Human cytomegalovirus infection of the monocyte/macrophage lineage in bone marrow. J. Virol. 68:4017-4021.

45. Mitchell, B. M., A. Leung, and J. G. Stevens. 1996. Murine cytomegalovirus DNA in peripheral blood of latently infected mice is detectable only in monocytes and polymorphonuclear leukocytes. Virology. 223:198-207.

46. Nudel, U., R. Zakut, M. Shani, S. Neuman, Z. Levy, and D. Yaffe. 1983. The nucleotide sequence of the rat cytoplasmic beta-actin gene. Nucleic Acids Res. 11:1759-1771.

47. Patel, R., and C. V. Paya. 1997. Infections in solid-organ transplant recipients. Clin. Microbiol. Rev. 10:86-124.

48. Persoons, M. C. J., F. S. Stals, M. C. E. VandamMieras, and C. A. Bruggeman. 1998. Multiple organ involvement during experimental cytomegalovirus infection is associated with disseminated vascular pathology. J. Pathol. 184:103-109.

49. Pollock, J. L., R. M. Presti, S. Paetzold, and H. W. Vingin. 1997. Latent murine cytomegalovirus infection in macrophages. Virology. 227:168-179.

50. Pomeroy, C., P. J. Hilleren, and M. C. Jordan. 1991. Latent murine cytomegalovirus DNA in splenic stromal cells of mice. J.Virol. 65:3330-3334. 
51. Prang, N., H. Wolf, and E. Schwarzmann. 1999. Latency of Epstein-Barr virus is stabilized by antisense-mediated control of the viral immediate-early gene BZLF-1. J. Med.Virol. 59:512-519.

52. Price, P., J. G. Winter, S. Nikoletti, J. B. Hudson, and G. R. Shellam. 1987. Functional changes in murine macrophages infected with cytomegalovirus relate to $\mathrm{H}$-2-determined sensitivity to infection. J. Virol. 61:3602-3606.

53. Reddehase, M. J., M. Balthesen, M. Rapp, S. Jonjic, I. Pavic, and U. H. Koszinowski. 1994. The conditions of primary infection define the load of latent viral genome in organs and the risk of recurrent cytomegalovirus disease. J. Exp. Med. 179:185-193.

54. Sharp, P. A. 2001. RNA interference-2001. Genes. Dev. 15:485-490.

55. Stals, F. S., F. Bosman, C. P. van Boven, and C. A. Bruggeman. 1990. An animal model for therapeutic intervention studies of CMV infection in the immunocompromised host. Arch. Virol. 114:91-107.

56. Stoddart, C. A., R. D. Cardin, J. M. Boname, W. C. Manning, G. B. Abenes, and E. S. Mocarski. 1994. Peripheral blood mononuclear phagocytes mediate dissemination of murine cytomegalovirus. J. Virol. 68:6243-6253.

57. Taylor Wiedeman, J., G. P. Hayhurst, J. G. Sissons, and J. H. Sinclair. 1993. Polymorphonuclear cells are not sites of persistence of human cytomegalovirus in healthy individuals. J. Gen. Virol. 74:265-268.

58. Taylor Wiedeman, J., J. G. Sissons, L. K. Borysiewicz, and J. H. Sinclair. 1991. Monocytes are a major site of persistence of human cytomegalovirus in peripheral blood mononuclear cells. J. Gen. Virol. 72:2059-2064.

59. Taylor Wiedeman, J., P. Sissons, and J. Sinclair. 1994. Induction of endogenous human cytomegalovirus gene expression after differentiation of monocytes from healthy carriers. J. Virol. 68:1597-1604.

60. van Dam, J. G., J. G. Damoiseaux, H. A. Van der Heijden, G. Grauls, P. J. Van Breda Vriesman, and C. A. Bruggeman. 1997. Infection with rat cytomegalovirus (CMV) in the immunocompromised host is associated with the appearance of a T cell population with reduced CD8 and T cell receptor (TCR) expression. Clin. Exp. Immunol. 110:349-357.

61. Vink, C., E. Beuken, and C. A. Bruggeman. 2000. Complete DNA sequence of the rat cytomegalovirus genome. J. Virol. 74:7656-7665.

62. White, K. L., B. Slobedman, and E. S. Mocarski. 2000. Human cytomegalovirus latencyassociated protein pORF94 is dispensable for productive and latent infection. J. Virol. 74:93339337.

63. Wilson, E. J., D. N. Medearis, Jr., L. V. Barrett, and R. H. Rubin. 1985. Activation of latent murine cytomegalovirus in cardiac explant and cell cultures. J. Infect. Dis. 152:625-626.

64. Yu, Y., S. C. Henry, F. Xu, and J. D. Hamilton. 1995. Expression of a murine cytomegalovirus early-late protein in "latently" infected mice. J. Infect. Dis. 172:371-379.

65. Yuhasz, S. A., V. B. Dissette, M. L. Cook, and J. G. Stevens. 1994. Murine cytomegalovirus is present in both chronic active and latent states in persistently infected mice. Virology. 202:272280.

66. Zhuravskaya, T., J. P. Maciejewski, D. M. Netski, E. Bruening, F. R. Mackintosh, and S. St Jeor. 1997. Spread of human cytomegalovirus (HCMV) after infection of human hematopoietic progenitor cells: model of HCMV latency. Blood. 90:2482-2491. 
CHAPTER 5 
CHAPTER 6

General Discussion 
CHAPTER 6 
Infections with $\mathrm{HCMV}$ are very common. In general, infections of immunocompetent individuals remain asymptomatic. In contrast, infection of immunocompromised individuals, such as patients with AIDS, solid organ and bone marrow transplant recipients, can result in a symptomatic infection and may even lead to death. Currently, effective antiviral treatment is possible. Ganciclovir is the most commonly used antiviral drug for the prevention and treatment of symptomatic HCMV infection. However, antiviral treatment is most effective when the patient is treated at an early stage of infection. In general, the preferred approach is therefore to initiate antiviral treatment before onset of apparent symptoms of infection. This preemptive strategy relies on the early detection of aberrant HCMV activity using a diagnostic assay (24). On the other hand, due to the adverse side effects of the drug and possible development of viral resistance against the drug, treatment of patients should be limited. Furthermore, delayed initiation of therapy may allow priming of host antiviral immune responses which may contribute to recovery and long-term control of the infection. Therefore, the assay should not only be sensitive but also have a high positive predictive value (PPV) for the onset of symptomatic infection.

Detection of infectious virus in blood is considered as the hallmark for development of symptomatic infection. The assays used in most routine diagnostics laboratories for the detection of HCMV in blood samples are based either on the detection of infectious virus, viral antigen, or viral DNA (see also chapter 1). The detection of infectious virus by cell culture is relatively slow and insensitive and therefore not suitable to act as a guide for preemptive antiviral therapy. The pp65-antigenemia assay is the most commonly used assay for the detection of viral antigen. This assay is more sensitive than viral culture, although its specificity for the onset of symptomatic infection can be low. The qualitative detection of viral DNA by PCR is highly sensitive. However, since PCR can also detect latent viral DNA, the specificity of this test is very low. Alternatively, the viral DNA load can be measured using quantitative PCR. The dynamics of the viral load in the blood are better correlated with disease progression. Nevertheless, quantitation of DNA in blood is not consistently correlated with actual virus replication in vivo (7). The detection of viral mRNA expression by RT-PCR or NASBA is expected to reflect viral activity more directly, due to high turnover of RNA molecules and the possibility to detect viral transcripts that are selectively expressed during active viral replication. Previously, various studies on the detection of viral mRNA expression as markers for viral activity were performed. However, these studies are difficult to compare due to the lack of standardization between the different assays. In this thesis, the development of standardized NASBA assays is described for the detection of two different viral transcripts: the immediate-early (IE)-1 and the late pp67 mRNA. The IE-1 mRNA is expressed during the very early stages of viral lytic gene 
expression (26). In contrast, the pp67 mRNA is abundantly expressed in the late phase of infection $(3,4)$. The diagnostic value of the NASBA assays for the detection of IE- 1 and pp67 mRNA in blood samples of renal and liver allograft recipients was determined. In studies by other groups, these assays were also evaluated for other patient groups as outlined below.

Initially, the use of monitoring pp67 mRNA expression in whole blood samples was investigated for renal transplant patients (chapter 2). From this study it was concluded that the sensitivity of the pp67 NASBA assay is higher than that of the antigenemia assay for the detection of active CMV infection ( $50 \%$ versus $34 \%$ ). In a subsequent study, the evaluation of the pp67 NASBA assay was extended for a larger group of renal transplant patients. This study had a similar outcome $(8,9)$. A higher sensitivity of the pp67 NASBA assay compared to the antigenemia assay for the detection of active CMV infection was also reported in a study for thoracic organ transplant recipients by Oldenburg et al. (21). In the studies on renal and thoracic organ transplant patients, active CMV infection was defined by the combined positive results for cell culture, antigenemia and serological assays. Since renal transplant patients receive relatively low doses of immunosuppressive drugs they are at lower risk for the development of symptomatic infection compared to other organ transplant recipients (22). The antigenemia or cell culture results were therefore not used to guide early preemptive antiviral treatment (chapter 2). If possible, the dosage of immunosuppressive drugs was diminished upon detection of HCMV, to allow the development of an adequate immune response by the patient. Antiviral treatment with ganciclovir was only initiated based on the first clinical symptoms of a symptomatic infection, confirmed by positive results for viral culture and/or the antigenemia assay. In these symptomatic patients, both pp67 mRNA and pp65-antigen could be detected. This demonstrated that the diagnostic value of these assays for monitoring HCMV infection in renal transplant patients was comparable. In the study with thoracic organ transplant patients described by Oldenburg et al. (21), the start of antiviral treatment was based on clinical symptoms or antigenemia results of $\geq 10$ pp65-antigen positive cells per $2 \times 10^{5}$ leukocytes. The expression of pp67 mRNA was found 1.1 weeks before this treshold was reached. It was therefore suggested that the pp67 NASBA assay could be used to guide preemptive antiviral treatment in these patients (21). These results are in agreement with the findings of Gerna et al. (6), who used a cut-off level of $\geq 100$ pp65-antigen positive cells per $2 \times 10^{5}$ leukocytes for the initiation of antiviral therapy in solid organ transplant recipients with a secondary infection. Positive pp67 NASBA results also preceded this cutoff value by several days. In contrast, pp67 NASBA positive results were found to be delayed compared to the first antigenemia positive results in bone marrow and solid organ 
transplant recipients with a primary infection. Antiviral therapy in these patients was initiated upon the finding of the first positive antigenemia results. Delayed detection of pp67 mRNA compared to clinically relevant levels of pp65 antigen were also reported for a group of lung transplant patients (13). However, it should be noted that the reported discrepancies between the antigenemia assay and the pp67 NASBA assay in the retrospective studies are possibly related to the early start of antiviral treatment based on the first antigenemia-positive results. Since ganciclovir exerts its antiviral effect by the inhibition of the viral DNA polymerase, it is expected that the expression of late mRNA, which is dependent upon viral replication, is also inhibited. This notion is further supported by the outcome of a study performed for liver transplant patients (chapter 3). In this study, the start of antiviral therapy was based on the first clinical signs of a symptomatic CMV infection and antigenemia positive results. The sensitivity of the pp67 NASBA assay for the onset of a symptomatic infection in the liver transplant patients was found to be only $60 \%$. The pp67 NASBA assay was also found to be less sensitive than the antigenemia assay in a study on renal transplant patients by Pellegrin et al. (23). These patients were preemptively treated with ganciclovir based on the first positive antigenemia results.

In conclusion, the detection of pp67 mRNA appears to be mainly correlated with the peak of systemic HCMV replication and spread and its detection can therefore be delayed compared to the antigenemia assay. This raises the question whether the pp67 NASBA assay results can be used to guide a preemptive therapy approach since this could result in an unacceptable increase in the risk for the onset of a symptomatic infection. Conversely, delayed initiation of antiviral therapy may be beneficial for the patient if this results in the development of an adequate immune response that accelerates recovery and generates improved long-term immunity against the virus. These issues should be investigated in controlled prospective studies. It is expected that for some patients delayed initiation of antiviral treatment could be justified, such as low risk solid organ transplant recipients with a secondary infection. For the patients at high risk, such as bone marrow transplant patients and specific groups of solid organ transplant recipients, delayed initiation of antiviral therapy may be unacceptable.

In addition to the pp67 NASBA assay, the IE NASBA assay was used for monitoring CMV infection in renal (chapter 3) and liver transplant patients (chapter 4). In studies performed by other laboratories, the diagnostic value of the IE NASBA assay was also evaluated for other solid organ and bone marrow transplant recipients $(5,13,21)$. In all these studies it was consistently found that the IE NASBA assay is very sensitive. However, detection of IE mRNA is not necessarily correlated with the onset of aberrant viral activity 
or symptomatic infection. As a consequence, the specificity of the IE NASBA assay for the onset of a symptomatic infection is low. Nevertheless, the IE NASBA assay was usually the first assay that indicated the onset of CMV infection. In particular in those patients at high risk for symptomatic infection, i.e. solid organ transplant recipients with a primary infection, bone marrow transplant patients, or patients that receive anti-rejection therapy, preemptive therapy could be based on the early detection of IE-1 mRNA (chapter 3 and 4; (5)). In patients at low risk for symptomatic HCMV infection, this would result in the unnecessary treatment of many patients, due to low PPV of the assay in these patients. Recently, a quantitative assay for the detection of IE-1 mRNA was developed (11). Using this assay, a good correlation between the levels of IE-1 mRNA expression and progression of HCMV infection was found in lung transplant patients (13). More extensive studies are needed to determine cut-off levels for IE-1 mRNA expression. Ideally, levels of mRNA expression above the cut-off should be predictive for the onset of symptomatic infection and provide a rationale for the initiation of antiviral therapy. Expression levels below the cut-off level could be indicative for low viral activity, whereas intensified monitoring of a patient is needed if the IE-1 levels start to rise but have not reached the cut-off value yet. In contrast to the quantification of IE-1 mRNA expression, quantification of the levels of pp67 mRNA did not appear to have additional value compared to the qualitative assay, since detection of this mRNA is strongly correlated with the peak of infection, as discussed above (13).

In conclusion, detection of CMV mRNA expression using NASBA is of added diagnostic value compared to existing assays for monitoring the course of infection because of its dynamic nature which more directly reflects viral activity. Simultaneous quantitation of the levels of IE-1 mRNA expression, and qualitative determination of the presence of pp67 mRNA in a multiplex assay as recently described (10), may result in an assay that is highly sensitive and predictive for the onset of a symptomatic HCMV infection. Monitoring the expression of other viral genes, such as the immune evasion genes US3, US6 and US11 did not appear to have much additional diagnostic value compared to the IE and pp67 NASBA assays (12). However, it may be useful to investigate the diagnostic value of detection of other viral transcripts or transcripts generated by the host in response to viral infection. It is expected that broad analysis of viral and host gene expression in microarrays may result in the identification of several of these transcripts and further fine-tuning of diagnostic parameters in transplant populations.

The second aim of this thesis was to monitor viral activity of RCMV in immunocompetent rats during acute and latent infection (chapter 5). In previous studies, rats were usually immunocompromised by gamma-irradiation before infection to allow 
efficient replication of the virus. Under these conditions, pathogenic effects of RCMV infection are more pronounced and can be studied more easily. In contrast, similar to HCMV infection in humans, RCMV infection of immunocompetent rats remains asymptomatic and is not lethal, even when high a dosis of virus is administered. In this respect, the RCMV infection model is a better animal model for HCMV infection than MCMV infection, since infection of healthy mice results in high virus titers in different organs and can even be lethal $(1,27)$.

Using PCR, RT-PCR and plaque assay, it was found that RCMV replication is severely restricted in immunocompetent rats (chapter 5). Although the expression of early and late mRNA could be detected at 7 days pi in various organs and blood, detectable levels of infectious virus were not found. In addition, IE-1 mRNA expression was only occasionally detected. At 120 days pi, virus persisted in the salivary glands as indicated by the presence of infectious virus, whereas in other organs exclusively viral DNA was detected in a limited number of cases. The presence of latent virus in multiple organs during long-term RCMV infection has also been reported for $\operatorname{MCMV}(2,17)$ and parallels observations in autopsy specimens of humans $(15,16,30)$. In contrast, molecular studies on mechanisms of latent HCMV infection focussed primarily on blood and bone-marrow cells $(20,28,29,31)$. This could merely reflect the problem to obtain biopsies of other organs and tissues from healthy individuals to study latent HCMV infection.

The inability to detect RCMV IE-1 mRNA during acute infection in blood cells of immunocompetent rats appears to contradict the findings reported above for monitoring HCMV IE-1 mRNA expression in blood using NASBA. From these studies it was concluded that detection of HCMV IE-1 mRNA is not necessarily correlated with the production of detectable levels of infectious virus. In contrast, RCMV IE-1 mRNA was mainly detected during productive infection in salivary glands and during lytic infection of REF in vitro. Importantly, the studies for HCMV were performed with immunocompromised patients after organ transplantation, whereas the infected rats were healthy and immunocompetent. In this respect, it is relevant to note that in healthy HCMV-infected humans also no HCMV transcripts could be detected $(12,13)$. This suggest that the presence of a fully functional immune system is responsible for the restriction of IE-1 mRNA expression. It may well be that HCMV IE-1 mRNA expression is also restricted upon primary infection in healthy subjects, however this is difficult to investigate due to the limited availability of samples during this phase of infection.

The mechanisms that are directly involved in the restriction of RCMV IE-1 mRNA expression are currently unknown. Interestingly, two novel antisense mRNAs were identified in the MIE region. These transcripts are complementary to and partly overlap 
with the IE-1 transcript (chaper 5). The role of these transcripts is still enigmatic. A similar antisense transcript was detected for HCMV (18). Interestingly, the expression of this transcript was reported to be strictly associated with a latent HCMV infection. By contrast, the detection of the RCMV antisense transcripts was detected at 7 days pi in blood cells, and in productively infected salivary glands at 120 days pi. It is tempting to speculate that direct hybridization of antisense to sense mRNA is involved in the downregulation of IE-1 mRNA expression. Formation of double stranded RNA was recently recognized as an important mechanism in post-transcriptional gene silencing in higher eukaryotes (14, 19 , 25). However, the existence of such a mechanism in herpesvirus gene expression has not yet been demonstrated. 


\section{REFERENCES}

1. Allan, J. E., and G. R. Shellam. 1984. Genetic control of murine cytomegalovirus infection: virus titres in resistant and susceptible strains of mice. Arch. Virol. 81:139-150.

2. Collins, T., C. Pomeroy, and M. C. Jordan. 1993. Detection of latent cytomegalovirus DNA in diverse organs of mice. J. Infect. Dis. 168:725-729.

3. Davis, M. G., and E.-S. Huang. 1985. Nucleotide sequence of a human cytomegalovirus DNA fragment encoding a 67 -kilodalton phosphorylated viral protein. J. Virol. 56:7-11.

4. Davis, M. G., E.-C. Mar, Y.-M. Wu, and E.-S. Huang. 1984. Mapping and expression of a human cytomegalovirus major viral protein. J. Virol. 52:129-135.

5. Gerna, G., F. Baldanti, D. Lilleri, M. Parea, E. Alessandrino, A. Pagani, F. Locatelli, J. Middeldorp, and M. G. Revello. 2000. Human cytomegalovirus immediate-early mRNA detection by nucleic acid sequence-based amplification as a new parameter for preemptive therapy in bone marrow transplant recipients. J. Clin. Microbiol. 38:1845-1853.

6. Gerna, G., F. Baldanti, J. M. Middeldorp, M. Furione, M. Zavattoni, D. Lilleri, and M. G. Revello. 1999. Clinical significance of expression of human cytomegalovirus pp67 late transcript in heart, lung, and bone marrow transplant recipients as determined by nucleic acid sequencebased amplification. J. Clin. Microbiol. 37:902-911.

7. Gerna, G., M. Zavattoni, F. Baldanti, A. Sarasini, L. Chezzi, P. Grossi, and M. G. Revello. 1998. Human cytomegalovirus (HCMV) leukodnaemia correlates more closely with clinical symptoms than antigenemia and viremia in heart and heart-lung transplant recipients with primary HCMV infection. Transplantation. 65:1378-1385.

8. Goossens, V. J., M. J. Blok, M. H. Christiaans, P. Sillekens, J. M. Middeldorp, and C. A. Bruggeman. 2000. Early detection of cytomegalovirus in renal transplant recipients: comparison of PCR, NASBA, pp65 antigenemia, and viral culture. Transplant. Proc. 32:155-158.

9. Goossens, V. J., M. J. Blok, M. H. Christiaans, J. P. van Hooff, P. Sillekens, K. Hockerstedt, I. Lautenschlager, J. M. Middeldorp, and C. A. Bruggeman. 1999. Diagnostic value of nucleicacid-sequence- based amplification for the detection of cytomegalovirus infection in renal and liver transplant recipients. Intervirology. 42:373-381.

10. Greijer, A. E., H. M. Adriaanse, C. A. Dekkers, and J. M. Middeldorp. Multiplex real-time NASBA for monitoring expression dynamics of human cytomegalovirus encoded IE1 and pp67 RNA. J. Clin. Virol. in press.

11. Greijer, A. E., H. M. Adriaanse, M. Kahl, N. M. Tacken, N. Oldenburg, A. Sijlmans, J. M. van de Crommert, C. A. Dekkers, P. T. Sillekens, and J. M. Middeldorp. 2001. Quantitative competitive NASBA for measuring mRNA expression levels of the immediate early 1, late pp67, and immune evasion genes US3, US6 and US11 in cells infected with human cytomegalovirus. J. Virol. Methods. 96:133-147.

12. Greijer, A. E., E. A. Verschuuren, C. A. Dekkers, H. M. Adriaanse, W. van Der Bij, T. H. The, and J. M. Middeldorp. 2001. Expression dynamics of human cytomegalovirus immune evasion genes US3, US6, and US11 in the blood of lung transplant recipients. J. Infect. Dis. 184:247-255. 
13. Greijer, A. E., E. A. Verschuuren, M. C. Harmsen, C. A. Dekkers, H. M. Adriaanse, T. H. The, and J. M. Middeldorp. 2001. Direct quantification of human cytomegalovirus immediate-early and late mRNA levels in blood of lung transplant recipients by competitive nucleic acid sequence-based amplification. J. Clin. Microbiol. 39:251-259.

14. Hammond, S. M., A. A. Caudy, and G. J. Hannon. 2001. Post-transcriptional gene silencing by double-stranded RNA. Nat. Rev. Genet. 2:110-119.

15. Hendrix, M. G., E. Beuken, R. L. Slobbe, and C. A. Bruggeman. 1996. Detection and sequence analysis of the major immediate early and PP150 gene of latent human cytomegalovirus in spleen, liver, and kidney tissues of trauma victims. J. Med. Virol. 50:193-197.

16. Hendrix, M. G., M. Daemen, and C. A. Bruggeman. 1991. Cytomegalovirus nucleic acid distribution within the human vascular tree. Am. J. Pathol. 138:563-567.

17. Klotman, M. E., S. C. Henry, R. C. Greene, P. C. Brazy, P. E. Klotman, and J. D. Hamilton. 1990. Detection of mouse cytomegalovirus nucleic acid in latently infected mice by in vitro enzymatic amplification. J. Infect. Dis. 161:220-225.

18. Kondo, K., J. Xu, and E. S. Mocarski. 1996. Human cytomegalovirus latent gene expression in granulocyte-macrophage progenitors in culture and in seropositive individuals. Proc. Natl. Acad. Sci. USA. 93:11137-11142.

19. Kumar, M., and G. G. Carmichael. 1998. Antisense RNA: function and fate of duplex RNA in cells of higher eukaryotes. Microbiol. Mol. Biol. Rev. 62:1415-1434.

20. Minton, E. J., C. Tysoe, J. H. Sinclair, and J. G. Sissons. 1994. Human cytomegalovirus infection of the monocyte/macrophage lineage in bone marrow. J. Virol. 68:4017-4021.

21. Oldenburg, N., K. M. Lam, M. A. Khan, B. Top, N. M. Tacken, A. McKie, G. W. Mikhail, J. M. Middeldorp, A. Wright, N. R. Banner, and M. Yacoub. 2000. Evaluation of human cytomegalovirus gene expression in thoracic organ transplant recipients using nucleic acid sequence-based amplification. Transplantation. 70:1209-1215.

22. Patel, R., and C. V. Paya. 1997. Infections in solid-organ transplant recipients. Clin. Microbiol. Rev. 10:86-124.

23. Pellegrin, I., I. Garrigue, D. Ekouevi, L. Couzi, P. Merville, P. Merel, G. Chene, M. H. Schrive, P. Trimoulet, M. E. Lafon, and H. Fleury. 2000. New molecular assays to predict occurrence of cytomegalovirus disease in renal transplant recipients. J. Infect. Dis. 182:36-42.

24. Rubin, R. H. 1991. Preemptive therapy in immunocompromised hosts. N. Engl. J. Med. 324:10571059.

25. Sharp, P. A. 2001. RNA interference--2001. Genes. Dev. 15:485-490.

26. Stenberg, R. M., D. R. Thomsen, and M. F. Stinski. 1984. Structural analysis of the major immediate early gene of human cytomegalovirus. J. Virol. 49:190-199.

27. Stoddart, C. A., R. D. Cardin, J. M. Boname, W. C. Manning, G. B. Abenes, and E. S. Mocarski. 1994. Peripheral blood mononuclear phagocytes mediate dissemination of murine cytomegalovirus. J. Virol. 68:6243-6253.

28. Taylor Wiedeman, J., J. G. Sissons, L. K. Borysiewicz, and J. H. Sinclair. 1991. Monocytes are a major site of persistence of human cytomegalovirus in peripheral blood mononuclear cells. J. Gen. Virol. 72:2059-2064. 
29. Taylor Wiedeman, J., P. Sissons, and J. Sinclair. 1994. Induction of endogenous human cytomegalovirus gene expression after differentiation of monocytes from healthy carriers. J. Virol. 68:1597-1604.

30. Toorkey, C. B., and D. R. Carrigan. 1989. Immunohistochemical detection of an immediate early antigen of human cytomegalovirus in normal tissues. J. Infect. Dis. 160:741-751.

31. Zhuravskaya, T., J. P. Maciejewski, D. M. Netski, E. Bruening, E. R. Mackintosh, and S. St Jeor. 1997. Spread of human cytomegalovirus (HCMV) after infection of human hematopoietic progenitor cells: model of HCMV latency. Blood. 90:2482-2491. 


\section{SUMMARY}

Human cytomegalovirus (HCMV) is an important cause of morbidity and mortality in immunocompromised patients. Effective antiviral treatment is possible provided that it is initiated in the early phase of infection. In the first part of this thesis, the expression of the viral immediate early (IE)-1 and late pp67 mRNA in whole blood samples of renal and liver transplant patients was monitored using nucleic acid sequence-based amplification (NASBA). The IE- 1 and pp67 transcripts represent different stages in the replication cycle of the virus. The diagnostic value of these two assays for detection of CMV infection was investigated.

In chapter 2, the pp67 NASBA assay results obtained for renal transplant patients were compared in a retrospective study to the results of the pp65-antigenemia assay and viral culture. The sensitivity of the pp67 NASBA assay for the detection of active CMV infection appeared to be higher compared to the sensitivity of the antigenemia assay, whereas it was similar to that of viral culture. Active CMV infection was defined by combined positive results for antigenemia, viral culture and serological assays. Some patients developed clinical symptoms as a consequence of the onset of active CMV infection and received antiviral therapy. For these patients it was found that the sensitivity of the pp67 NASBA assay was similar to that of the pp65 antigenemia assay as well as viral culture. Finally, the pp67 NASBA assay appeared to be suitable for monitoring the effect of antiviral therapy. Taken together, it was concluded that the diagnostic value of the pp67 NASBA assay for detecting HCMV infection in renal transplant patients is comparable to that of the antigenemia assay and viral culture.

The blood samples of the same group of renal transplant patients as described in chapter 2, were also used for a retrospective evaluation of the diagnostic value of the IE NASBA assay (chapter 3). This assay proved to be the most sensitive assay, detecting the onset of both primary and secondary infection significantly earlier than viral culture, the pp67 NASBA and antigenemia assay. However, the specificity of this assay was low, indicating that the detection of IE-1 mRNA in blood of renal transplant patients is not necessarily correlated with the onset of a clinically relevant HCMV infection. It was therefore concluded that only for patients at high risk for the development of a symptomatic infection, i.e. patients with a primary infection or under rejection therapy, early detection of CMV transcriptional activity is valuable and could possibly be used as a parameter for the start of preemptive antiviral treatment.

A similar evaluation as described for renal transplant patients using the IE and pp67 NASBA assays was performed for liver transplant patients and is described in chapter 4 . In general, liver transplant patients are at higher risk for the onset of symptomatic infection than kidney transplant patients. Liver transplant patients are usually in a critical clinical condition 
at the moment of transplantation and frequently require anti-rejection treatment. As a consequence, these patients are highly susceptible to infections with opportunistic pathogens, such as CMV. Nevertheless, the specificity of the IE NASBA assay for the onset of a symptomatic infection in liver transplant patients was low. Thus, as was concluded for kidney transplant patients, IE NASBA results are not suitable as a guide to initiate antiviral therapy, except for those patients that are at high risk for the onset of symptomatic infection. In contrast to what was reported for renal transplant patients, pp67 NASBA appeared to be less sensitive than the antigenemia assay for the detection of a symptomatic infection. However, in this study, initiation of antiviral therapy was based on the first clinical signs of a symptomatic infection confirmed by antigenemia-positive results. Since antiviral treatment using ganciclovir rapidly results in the inhibition of viral replication and late mRNA expression, it is possible that an early start of antiviral therapy prevented subsequent detection of late pp67 mRNA by NASBA. Prospective studies should be performed to investigate whether delayed initiation of antiviral therapy for these liver transplant patients based on positive pp67 NASBA results would still allow the start of effective antiviral therapy, without an unacceptable increased risk on the onset of severe symptomatic infection.

In contrast to HCMV infection in immunocompromised transplant patients, infection of healthy, immunocompetent individuals with HCMV usually remains asymptomatic. Studies to investigate the course of HCMV infection in healthy individuals are difficult to perform due to the limited availability of tissues and blood samples. Alternatively, infection of rats with rat cytomegalovirus (RCMV) is a useful model to perform these studies. Infection of immunocompromised rats results in active virus replication in various organs and can be lethal, whereas infection of immunocompetent rats remains asymptomatic and is not lethal even when a high dose of virus is injected. In chapter 5, dissemination and viral activity was investigated after infection of immunocompetent rats with RCMV. Rats were infected with RCMV and sacrificed at defined time-points post infection (pi). Several organs and tissues were collected from the rats and analyzed for the presence of viral DNA, IE-1 (R123), early (R44) and late (R32) mRNA, as well as infectious virus. It was found that both IE-1 mRNA expression and production of infectious virus are restricted during acute infection at 7 days pi, although early and late mRNA could be detected. In general, IE-1 mRNA was only detected in the presence of detectable amounts of infectious virus, in particular in the salivary glands and during productive infection in vitro. The mechanims that are involved in the restriction of IE-1 mRNA expression in immunocompetent rats are currently unknown. Interestingly, we identified two novel transcripts, that are complementary to the IE-1 transcript. The elucidation of the function of these antisense transcripts and their putatively encoded proteins will be the subject of future investigations. 


\section{SAMENVATTING}

Humaan cytomegalovirus (HCMV) is een belangrijke oorzaak van ziekte en sterfte in immuungecompromiteerde patiënten. Effectieve antivirale behandeling is mogelijk mits deze wordt gestart in de vroege fase van infectie. In het eerste deel van dit proefschrift werd de expressie van het virale "immediate early" (IE)-1 en "late" pp67 mRNA in volbloed monsters van nier-, en levertransplantatie patiënten gemonitord met behulp van "nucleic acid sequence-based amplification" (NASBA). De IE-1 en pp67 transcripten vertegenwoordigen ieder verschillende fases in de replicatie cyclus van het virus. De diagnostische waarde van deze twee testen voor de detectie van HCMV infectie werd onderzocht.

In hoofdstuk 2 werden in een retrospectieve studie voor niertransplantatie patiënten de resultaten van de pp67 NASBA test vergeleken met de resultaten van de pp65 antigenemie test en viruskweek. De gevoeligheid van de pp67 NASBA test voor de detectie van een actieve HCMV infectie bleek hoger te zijn dan de gevoeligheid van de antigenemie test, en was vergelijkbaar met de gevoeligheid van de viruskweek. Actieve HCMV infectie werd in deze studie gedefinieerd door gecombineerde positieve resultaten voor viruskweek, antigenemie en serologische testen. Sommige patiënten ontwikkelden ook klinische symptomen als gevolg van een actieve HCMV infectie en werden daarvoor behandeld met antivirale middelen. Voor deze patiënten werd gevonden dat de gevoeligheid van de pp67 NASBA test vergelijkbaar was met de gevoeligheid van zowel de antigenemie test als viruskweek. De pp67 NASBA test bleek tenslotte ook geschikt voor het monitoren van de effectiviteit van de antivirale therapie. Samenvattend kon gesteld worden dat de diagnostische waarde van de pp67 NASBA test voor de detectie van HCMV infectie in niertransplantatie patiënten vergelijkbaar is met die van de antigenemie test en viruskweek.

De bloedmonsters van dezelfde groep van niertransplantatie patiënten als beschreven in hoofdstuk 2 werden ook gebruikt voor een retrospectieve evaluatie van de diagnostische waarde van de IE NASBA test (hoofdstuk 3). Deze test bleek zeer gevoelig te zijn en detecteerde de ontwikkeling van een primaire of secundaire infectie significant eerder dan viruskweek, de pp67 NASBA en antigenemie test. De specificiteit van de IE NASBA test was echter laag. Dit houdt in dat de detectie van IE-1 mRNA in het bloed van niertransplantatie patiënten niet noodzakelijk gecorreleerd is met de ontwikkeling van een klinisch relevante HCMV infectie. Er werd daarom geconcludeerd dat alleen patiënten met een hoog risico op de ontwikkeling van een symptomatische infectie, in het bijzonder patiënten met een primaire infectie of patiënten die antivirale therapie krijgen, gebaad zijn bij een vroege detectie van transcriptie door HCMV. Voor deze patiënten kan de uitslag van de IE NASBA test mogelijk dienen als een parameter voor de start van preventieve antivirale therapie. 
Een vergelijkbare evaluatie voor de IE en pp67 NASBA testen als zojuist beschreven voor niertransplantatie patiënten werd uitgevoerd voor levertransplantatie patiënten, en is beschreven in hoofdstuk 4 . In het algemeen hebben levertransplantatie patiënten een hoger risico op de ontwikkeling van een symptomatische infectie dan niertransplantatie patiënten. Levertransplantatie patiënten zijn meestal in een kritieke klinische conditie op het moment van transplantatie en krijgen vaak anti-rejectie therapie. Als gevolg hiervan zijn deze patiënten zeer gevoelig voor infecties met opportunistische pathogenen zoals HCMV. Desondanks was de specificiteit van de IE NASBA test voor de ontwikkeling van een symptomatische infectie in levertransplantatie patiënten laag. Dus, zoals werd geconcludeerd voor de niertransplantatie patiënten, blijken IE NASBA test resultaten niet geschikt te zijn als leidraad voor de start van preventieve antivirale therapie, behalve voor specifieke patiënten die een hoog risico hebben op de ontwikkeling van een symptomatische infectie. In tegenstelling tot de gerapporteerde bevindingen voor niertransplantatie patiënten, bleek de pp67 NASBA test minder gevoelig te zijn dan de antigenemie test voor de detectie van een symptomatische infectie. In deze studie werd de start van antivirale therapie echter gebaseerd op het optreden van de eerste klinische verschijnselen van een symptomatische infectie, bevestigd door positieve antigenemie resultaten. Omdat antivirale therapie met ganciclovir direct tot een remming leidt van de virale replicatie en "late" mRNA expressie, is het mogelijk dat een vroege start van de antivirale therapie als gevolg had dat de detectie van het "late" pp67 mRNA door NASBA werd verhinderd. Prospectieve studies zouden moeten uitwijzen of een vertraagde start van antivirale therapie voor deze levertransplantatie patienten gebaseerd op positieve pp67 NASBA resultaten nog steeds effectief is, of dat dit resulteert in een onacceptabele verhoging van de kans op de ontwikkeling van een ernstige symptomatische infectie.

In tegenstelling tot $\mathrm{HCMV}$ infectie in immuungecompromiteerde transplantatie patiënten blijft de infectie van immuuncompetente individuen met HCMV in het algemeen asymptomatisch. Studies om het verloop van een HCMV infectie te onderzoeken in gezonde individuen zijn moeilijk uit te voeren vanwege de beperkte beschikbaarheid van weefsel- en bloedmonsters. Als alternatief is de infectie van ratten met rat cytomegalovirus (RCMV) een zeer bruikbaar diermodel voor het uitvoeren van dergelijke studies. Infectie van immuungecompromiteerde ratten resulteert in actieve virus replicatie en kan lethaal zijn. In tegenstelling, infectie van immuuncompetente ratten verloopt asymptomatisch en is niet dodelijk, zelfs wanneer een zeer hoge virus dosis wordt toegediend. In hoofdstuk 5 werd de verspreiding en activiteit van het virus onderzocht na infectie van immuuncompetente ratten met RCMV. Ratten werden geinfecteerd met RCMV en opgeofferd op gespecificeerde tijden na infectie. Verschillende rat organen en weefsels 
werden verzameld en getest op de aanwezigheid van viraal DNA, IE-1 (R123), "early" (R44) en "late" (R32) mRNA, en infectieus virus. Er bleek een restrictie op te treden van zowel IE-1 mRNA expressie als productie van infectieus virus tijdens acute infectie op dag 7 na infectie, alhoewel "early" en "late" mRNA wel op dat moment konden worden gedetecteerd. In het algemeen werd IE-1 mRNA alleen gedetecteerd in de aanwezigheid van detecteerbare hoeveelheden van infectieus virus, in het bijzonder in de speekselklieren en tijdens productieve infectie in vitro. De mechanismen die betrokken zijn bij de restrictie van IE-1 mRNA expressie in immuuncompetente ratten zijn op dit moment onbekend. Een interessante bevinding hierbij is het feit dat twee nieuwe transcripten konden worden geïdentificeerd die complementair zijn aan het IE-1 transcript. De opheldering van de functie van deze antisense transcripten en de eiwitten die mogelijk door deze transcripten worden gecodeerd, zal het onderwerp zijn van vervolgonderzoek. 


\section{DANKWOORD/ACKNOWLEDGMENTS}

Het beschreven onderzoek is voornamelijk uitgevoerd bij de afdeling Medische Microbiologie van het AZM en werd mogelijk gemaakt door de financiële steun van Organon Teknika B.V. te Boxtel. Voor het verkrijgen van patiëntenmonsters en klinische data voor de evaluatie van de NASBA testen was de medewerking van de afdelingen Interne Geneeskunde van het AZM, en de afdelingen Virologie en Chirurgie van het Academisch Ziekenhuis in Helsinki, Finland, onmisbaar. Graag wil ik een aantal mensen in het bijzonder bedanken voor hun bijdrage aan het tot stand komen van dit proefschrift.

Mijn eerste woord van dank gaat uit naar Cathrien Bruggeman voor de prettige samenwerking in de afgelopen jaren. Het feit dat er vrijwel altijd direct tijd kon worden vrijgemaakt voor het stellen van vragen en het oplossen van problemen heb ik zeer gewaardeerd. Ook heeft ze mij de mogelijkheid geboden om me als post-doc te kunnen gaan richten op de verdere ontwikkeling van de moleculaire diagnostiek binnen de afdeling Medische Microbiologie. Verder wil ik Kees Vink bedanken voor zijn kritische, doch meestal rechtvaardige mening tijdens het plannen van experimenten en het schrijven van artikelen. Afgewisseld met veel humor leverde dit een sfeer op waarin het prettig (gestoord) samenwerken was. Jaap Middeldorp heeft een belangrijke bijdrage gehad in het tot stand komen van het NASBA-project. Ondanks enkele meningsverschillen, hebben we toch een aanzienlijk deel van de plannen uiteindelijk kunnen verwezenlijken. Voor praktische hulp vanuit Organon Teknika met de NASBA testen kon ik terugvallen op de uitgebreide technische kennis van Peter Sillekens en Nicole Tacken. Verder wil ik dr. A. Ramon bedanken voor zijn bemiddelende rol bij het contact met Organon Teknika.

Voor de klinische evaluatie van de NASBA resultaten voor niertransplantatie patiënten is de bijdrage van de nefrologen prof. dr. J.P. van Hooff en dr. Maarten Christiaans van de afdeling Interne Geneeskunde in Maastricht zeer belangrijk geweest. Ook wil ik Valère Goossens bedanken voor zijn inbreng hierin. For the evaluation of the NASBA assays for liver transplant patients, I would like to acknowledge prof. dr. K. Höckerstedt en prof. dr. Irmeli Lautenschlager from the University Hospital in Helsinki for their willingness to collaborate. I also want to mention the excellent technical assistence of Raisa Loginov, Kristina Messina, and Kaarina Inkinen during this project. Bieke Vanherle was voor een groot deel verantwoordelijk voor de praktische uitvoering van het NASBA project in Maastricht. Haar geweldige inzet bij het uitvoeren van een groot aantal NASBA testen en het verwerken van de resultaten, ook in tijden van persoonlijke tegenspoed, vind ik bewonderenswaardig. Ik wil ook andere analisten van de Virologie bedanken, met name Martine Hulsbosch, Magdalena Garcia en Annick Hermans voor het verrichten van NASBA testen en serologie. 
Voor de praktische uitvoering van de ratproeven heb ik kunnen profiteren van de ruime ervaring van Gert Grauls. Voor iemand die eigenlijk niet graag een levende rat aanraakt is het verwonderlijk dat ze het al zo lang volhoudt met deze beestjes, maar misschien dat er daarom altijd een beroep op haar kan worden gedaan om er eentje op te offeren. Verder wil ik Joanne van Dam, Marjorie Nelissen en Jeroen Kloover bedanken voor hun hulp bij de ratproeven.

Voor het opzetten en uitvoeren van de testen die nodig waren om de verzamelde ratorganen te analyseren verdient Kim Savelkouls een eervolle vermelding. Ze heeft zich met succes een weg gebaand door een grote hoeveelheid testen waarbij het gevaar van contaminate voortdurend op de loer lag. PCR controles en de logische gedachte $6 \times 8=48$ hielden haar op de been. Een jaar geleden heeft deze prestatie haar al de "1-2-3 RT-PCR" award opgeleverd. Ik hoop dat zij de komende tijd deze titel zal blijven verdedigen. Er waren ook andere helden in het RCMV verhaal, met name Monique Coomans vanwege de vele RCMV PCRs en Martine Hulsbosch vanwege haar inzet tijdens het ontwikkelen van protocollen voor RT-PCR en DNA/RNA isolatie.

$\mathrm{Na}$ de ontberingen in het lab was het goed om weer thuis te komen in de zitkamer waar het vrijwel altijd, en soms te, gezellig was. Ik wil Erik, Joanne, Patrick, Suzanne, Yvonne, Jeroen, Kim, Koen en Lieve bedanken voor de plezierige samenwerking in de afgelopen tijd. Ik vind dat door het contact zowel op, als buiten het werk er een bijzondere collegiale band is ontstaan die elk ochtendhumeur met succes kan doorstaan. Ook andere mensen die in de loop van de jaren in de zitkamer en op het lab hun sporen hebben achtergelaten hebben hier een bijdrage in gehad, zoals Edward, Servi, Mohammed, Jim, Saskia, Susan, Bram, Jasper, Carola, Wil, Aafke en Regine. I also would like thank Timi, for the pleasant collaboration and his friendship.

Tenslotte gaat mijn dank uit naar het secretariaat van de afdeling Medische Microbiologie, met name Fia, voor het uit handen nemen van de administratieve taken rondom mijn promotie en naar het gehele team van ANDI Drukwerk Industrie te Geleen voor de mooie vormgeving en productie van het proefschrift. Familie en vrienden kunnen nu eindelijk rustig nalezen waar ik mee bezig ben geweest en wat het resultaat is geworden van al dat schrijven.

Rest mij nog om Marije te bedanken voor haar geduld, steun en liefde in de afgelopen periode. Ze is toch wel mijn belangrijkste ontdekking geweest in de afgelopen 4 jaar. De resultaten van deze ontdekking zijn zelfs onlangs geregistreerd bij de burgerlijke stand van Maastricht. Nu is het mijn taak om een eervolle vermelding te verwerven in het dankwoord van haar proefschrift. 


\section{CURRICULUM VITAE}

Rien Blok werd geboren op 26 april 1972 te Halsteren. In 1984 begon zijn middelbare schoolopleiding aan de scholengemeenschap 't Rijks in Bergen op Zoom. Het eindexamen VWO werd in 1990 behaald. In datzelfde jaar begon hij met de studie Bioprocestechnologie aan de Universiteit Wageningen. In 1994 werd de eerste afstudeeropdracht verricht bij de vakgroep Experimentele Diermorfologie en Celbiologie, met als onderwerp de ontwikkeling van monoclonale antilichamen tegen T-lymfocyten en macrofagen van de karper. Later dat jaar vertrok hij naar het Pasteur Instituut in Parijs, en deed daar onderzoek bij het "Laboratoire des Bunyavirides" aan het Rift Valley fever virus. Een laatste stage werd verricht bij de afdeling Porcine en Exotische Virusziekten, van het Instituut voor Dierhouderij en Diergezondheid te Lelystad. Hier werd gewerkt aan de moleculaire karakterisatie van een vaccin stam van het varkenspest virus. Eind 1995 behaalde hij cum laude de Ir. titel en in 1996 begon hij als AIO bij de afdeling Medische Microbiologie van het Academisch Ziekenhuis in Maastricht. In 2000 werd de aanstelling bij deze afdeling verlengd en werden de werkzaamheden uitgebreid met het opzetten en implementeren van nieuwe testen voor de moleculaire diagnostiek. 


\section{PUBLICATIONS}

Prehaud, C., N. Lopez, M.J. Blok, V. Obry, M. Bouloy. 1997. Analysis of the 3' terminal sequence recognized by the Rift Valley fever virus transcription complex in its ambisense $\mathrm{S}$ segment. Virology 227:189-197.

Blok, M.J., M.H.L. Christiaans, V.J. Goossens, J.P. van Hooff, B. Top, J.M. Middeldorp, and C.A. Bruggeman. 1998. Evaluation of a new method for early detection of active cytomegalovirus infections. A study in kidney transplant recipients. Transplant. Int. 11(suppl. 1): S107-S109.

Blok, M.J., V.J. Goossens, S.J.V. Vanherle, B. Top, N. Tacken, J.M. Middeldorp, M.H.L. Christiaans, J.P. van Hooff and C.A. Bruggeman. 1998. Diagnostic value of monitoring human cytomegalovirus late pp67 mRNA expression in renal allograft recipients by nucleic acid sequence-based amplification. J. Clin. Microbiol. 36:1341-1346.

Blok, M.J., M.H.L. Christiaans, V.J. Goossens, J.P. van Hooff , P. Sillekens, J.M. Middeldorp, and C.A. Bruggeman. 1999. Early detection of human cytomegalovirus infection after kidney transplantation by nucleic acid sequence-based amplification. Transplantation 67:1274-1277.

Blok, M.J., I. Lautenschlager, M.H.L. Christiaans, J.P. van Hooff , V.J. Goossens, J.M. Middeldorp, P. Sillekens, A. Ramon, K. Höckerstedt, and C.A. Bruggeman. 1999. Nucleic acid sequence-based amplification: a new technique for monitoring cytomegalovirus infection in transplant recipients. Transplant. Proc. 31:308-309.

Goossens, V.J., M.J. Blok, M.H.L. Christiaans, J.P. van Hooff, P. Sillekens, K. Höckerstedt, I. Lautenschlager, J.M. Middeldorp and C.A. Bruggeman. 1999. Diagnostic value of nucleic acid sequence-based amplification for detection of cytomegalovirus infection in renal and liver transplant recipients. Intervirology 42:373-381.

Blok, M.J., I. Lautenschlager, M.H.L. Christiaans, J.P. van Hooff, V.J. Goossens, J.M. Middeldorp, P. Sillekens, K. Höckerstedt, and C.A. Bruggeman. 2000. Sensitive detection of cytomegalovirus infection in transplant recipients using nucleic acid sequence-based amplification. Transplant. Proc. 32:149-151.

Goossens, V.J., M.J. Blok, M.H.L. Christiaans, P. Sillekens, J.M. Middeldorp, and C.A. Bruggeman. 2000. Early detection of cytomegalovirus in renal transplant recipients : comparison of PCR, NASBA, pp65-antigenemia and viral culture. Transplant. Proc. 32:155-158.

Beisser, P.S., J.S. Kloover, G.E. Grauls, M.J. Blok, C.A. Bruggeman, and C. Vink. 2000. The r144 major histocompatibility complex class I-like gene of rat cytomegalovirus is dispensable for both acute and long-term infection in the immunocompromised host. J.Virol. 74:1045-1050. 
Blok, M.J., I. Lautenschlager, V.J. Goossens, J.M. Middeldorp, C. Vink, K. Höckerstedt and C.A. Bruggeman. 2000. Diagnostic implications of human cytomegalovirus IE-1 and pp67 mRNA detection in whole-blood samples from liver transplant patients using nucleic acid sequence-based amplification. J. Clin. Microbiol. 38:4485-4491.

Martelius, T., M.J. Blok, K. Inkinen, R. Loginov, K. Höckerstedt, C.A. Bruggeman and I. Lautenschlager. 2001. CMV infection, viral DNA, and immediate early-1 gene expression in rejecting rat liver allografts. Transplantation 71:1257-1261.

Kloover, J.S., G. Grauls, M.J. Blok, C. Vink, and C.A. Bruggeman. 2001. A rat cytomegalovirus strain with a disruption of the r144 MHC class I-like gene is attenuated in the acute phase of infection in neonatal rats. Arch. Virol. In press.

Vliegen, I., F. Stassen, G. Grauls, M.J. Blok, and C.A. Bruggeman. MCMV infection increases T-lymphocyte influx in atherosclerotic lesions early after infection thereby aggravating the atherosclerotic process in apoE knockout mice. J. Clin. Virol. In press.

Kloover, J.S., A.E. van de Bogaard, J.G. van Dam, M.J. Blok, G. Grauls, C. Vink, and C.A. Bruggeman. Persistent rat cytomegalovirus (RCMV) infection of the salivary glands attributes significantly to the anti-RCMV antibody response in infected rats. Submitted. 


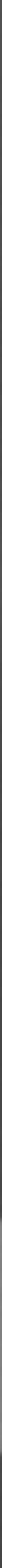

ISBN $90-9015374-8$ 